Prepared in cooperation with Clarke County

\title{
Hydrogeology and Groundwater Availability in Clarke County, Virginia
}

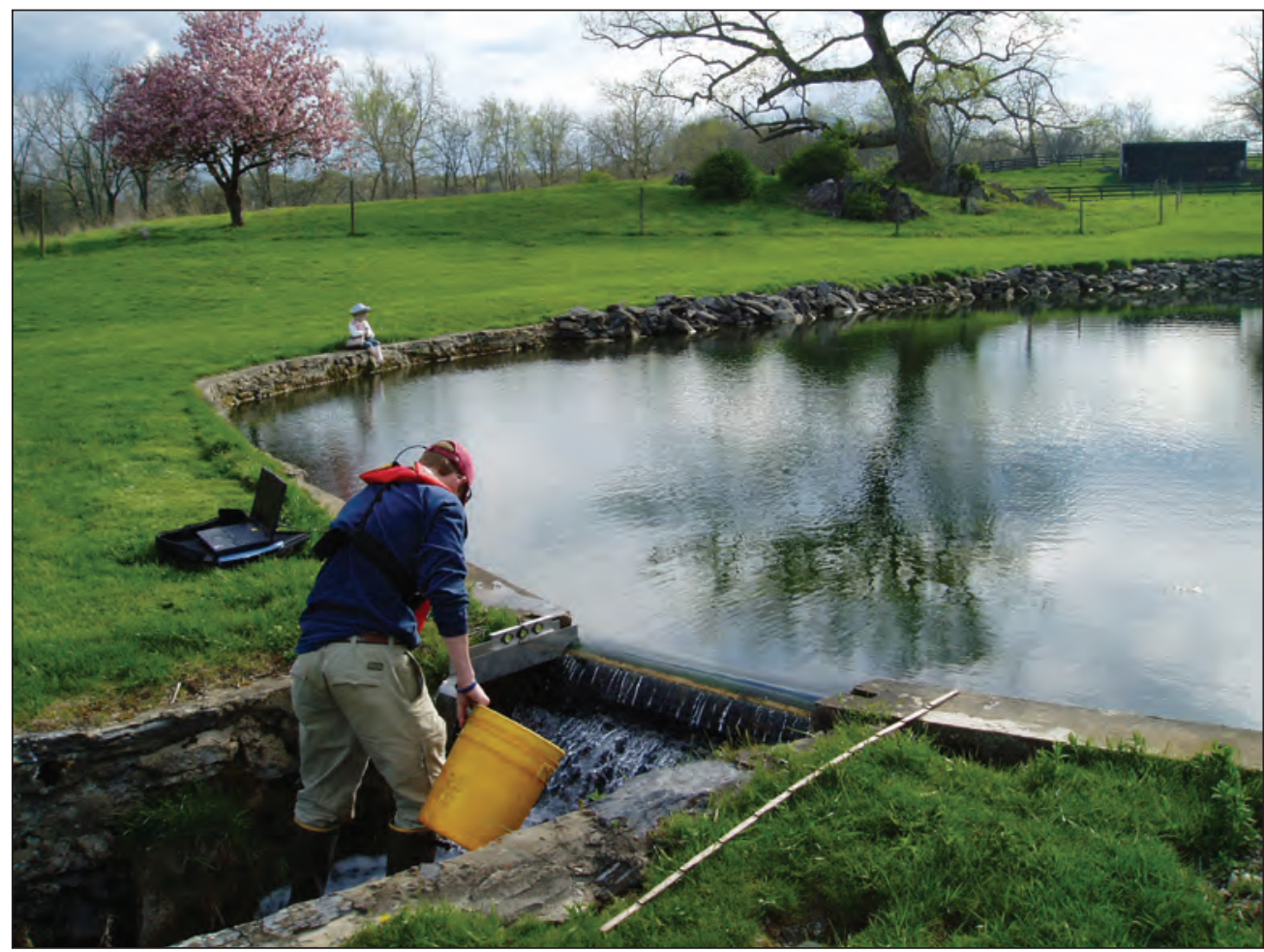

Scientific Investigations Report 2010-5112 
Cover photograph. Volumetric discharge measurement at spring 46WS 22. View looking west towards Boyce, Virginia. (Photograph by David L. Nelms, U.S. Geological Survey, April 2005) 


\section{Hydrogeology and Groundwater Availability in Clarke County, Virginia}

By David L. Nelms and Roger M. Moberg, Jr.

Prepared in cooperation with Clarke County

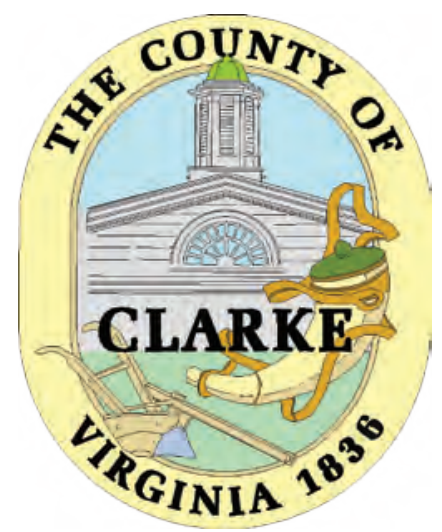

Scientific Investigations Report 2010-5112 


\title{
U.S. Department of the Interior \\ KEN SALAZAR, Secretary \\ U.S. Geological Survey \\ Marcia K. McNutt, Director
}

\section{U.S. Geological Survey, Reston, Virginia: 2010}

\author{
For more information on the USGS — the Federal source for science about the Earth, its natural and living resources, \\ natural hazards, and the environment, visit http://www.usgs.gov or call 1-888-ASK-USGS \\ For an overview of USGS information products, including maps, imagery, and publications, \\ visit http://www.usgs.gov/pubprod \\ To order this and other USGS information products, visit http://store.usgs.gov
}

Any use of trade, product, or firm names is for descriptive purposes only and does not imply endorsement by the U.S. Government.

Although this report is in the public domain, permission must be secured from the individual copyright owners to reproduce any copyrighted materials contained within this report.

Suggested citation:

Nelms, D.L., and Moberg, R.M., Jr., 2010, Hydrogeology and groundwater availability in Clarke County, Virginia: U.S. Geological Survey Scientific Investigations Report 2010-5112, 119 p.

(available online at http://pubs.usgs.gov/sir/2010/5112/) 


\section{Acknowledgments}

The authors gratefully acknowledge the many individuals, establishments, and authorities in Clarke County that permitted access to their wells and springs. The authors also thank the owners that granted access to their property for collection of water-level data and stream- and spring-discharge data. Special thanks is given to Alison Teetor of the Clarke County Planning Department for her efforts with project logistics and data collection.

The authors would like to acknowledge the contributions of J. Alton Anderson, Daniel H. Doctor, George E. Harlow, Jr., Donald C. Hayes, Seth Haynes, John W. Lane, Jr., Frederick D. Day-Lewis, Kurt J. McCoy, Randall C. Orndorff, Gary K. Speiran, Michael W. Strader, Jr., David J. Weary, and Eric A. White of the U.S. Geological Survey; and T. Scott Bruce, Todd A. Beach, Joel P. Maynard, and Brad A. White with the Virginia Department of Environmental Quality; and Wil Orndorff of the Virginia Department of Conservation and Recreation for their efforts in the collection and analyses of geologic and geophysical data during this investigation. 


\section{Contents}

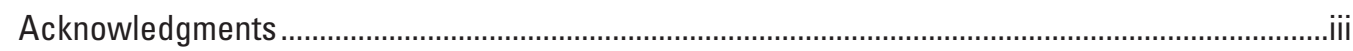

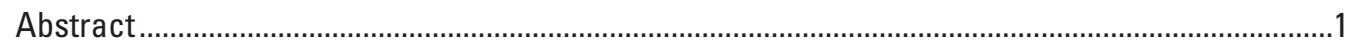

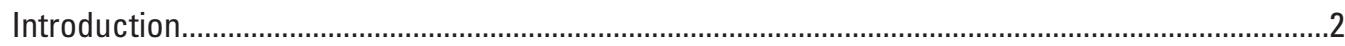

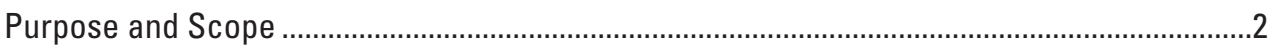

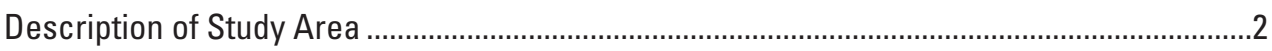

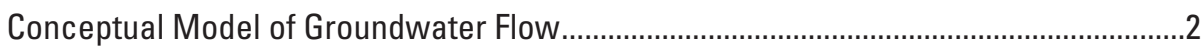

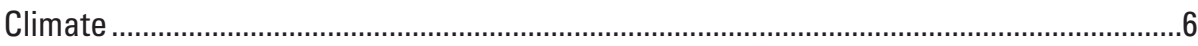

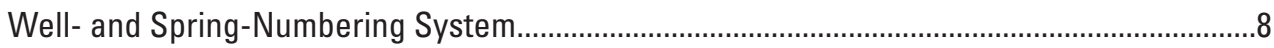

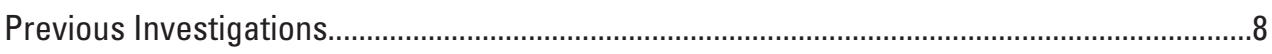

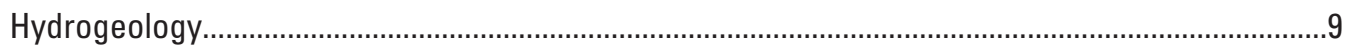

Geology

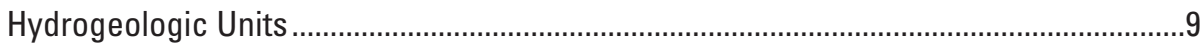

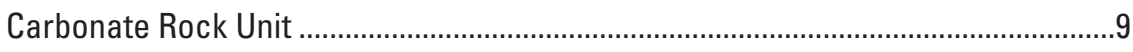

Tomstown Dolomite ……………………......................................................

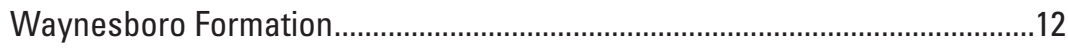

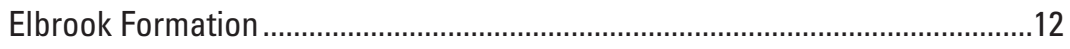

Conococheague Limestone ........................................................................12

Stonehenge Limestone of the Beekmantown Group .......................................12

Rockdale Run Formation of the Beekmantown Group ...................................12

Pinesburg Station Dolomite of the Beekmantown Group ................................12

New Market Limestone ....................................................................................13

Lincolnshire Limestone ..............................................................................13

Edinburg Formation .............................................................................13

Chambersburg Limestone .......................................................................13

Metamorphic Rock Unit.....................................................................................13

Catoctin Formation .......................................................................................13

Loudoun Formation of the Chilhowee Group..................................................13

Weverton Formation of the Chilhowee Group..................................................13

Harpers Formation of the Chilhowee Group.....................................................14

Antietam Formation of the Chilhowee Group ....................................................14

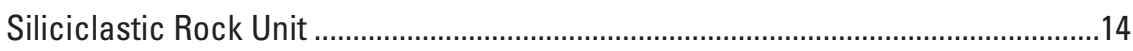

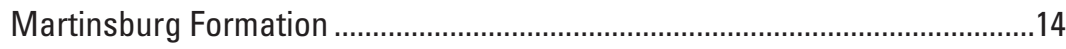

Structural Geology

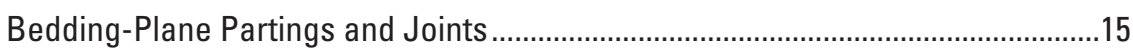

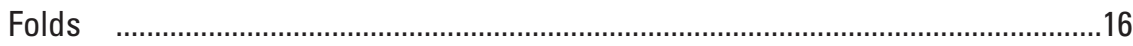

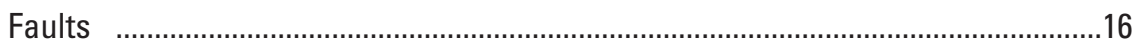

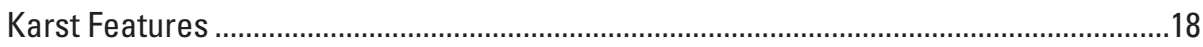

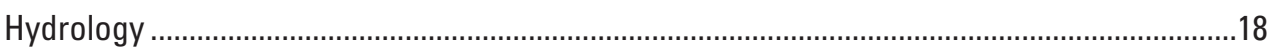

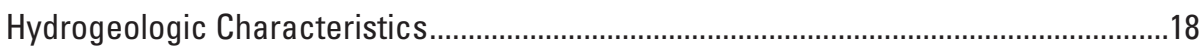

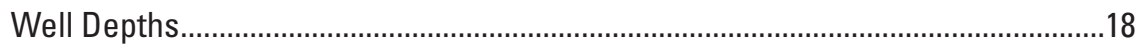

Well Yields .......................................................................................................

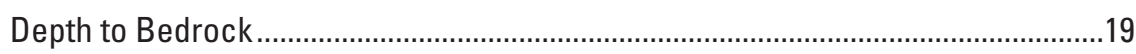




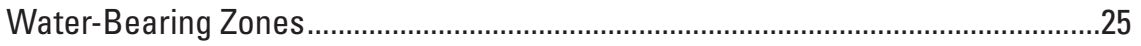

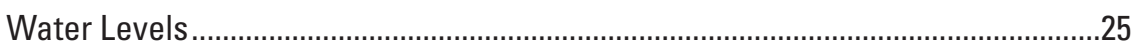

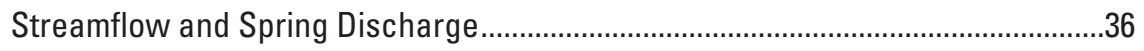

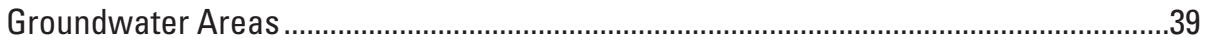

Relation of Geology to Groundwater Flow....................................................................

Relation Between Groundwater and Surface Water...................................................42

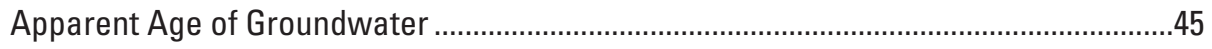

Revised Conceptual Model of Groundwater Flow ........................................................49

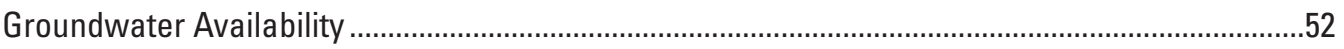

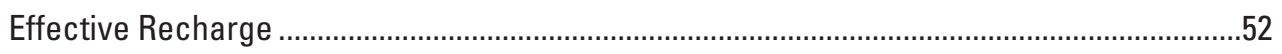

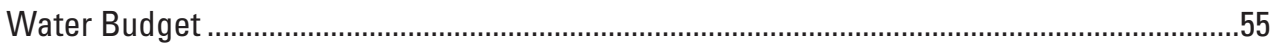

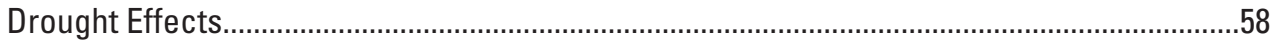

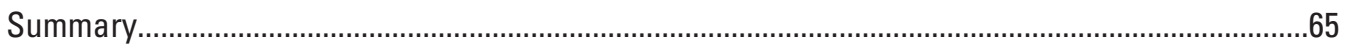

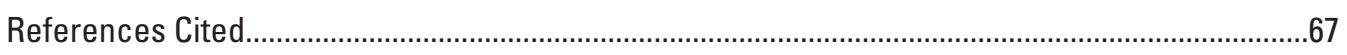

Appendix 1. Record of selected wells in Clarke County, Virginia ................................................74

Appendix 2. Record of selected springs in Clarke County, Virginia ..............................................76

Appendix 3. Water-level measurements from wells in Clarke County, Virginia, 2002-2008...........77

Appendix 4. Discharge and water-quality field properties from streams and springs in Clarke County, Virginia, 2003-2008 ……...........................................99

Appendix 5. Summary of average dissolved gas compositions (nitrogen, argon, oxygen, carbon dioxide, methane, and neon), recharge temperatures, and quantities of excess air in water samples from springs in Clarke County, Virginia, 2003-2005

Appendix 6. Concentrations of chlorofluorocarbons and sulfur hexafluoride in North American air, 1940-2006.

Appendix 7. Summary of average chlorofluorocarbon concentrations and calculated atmospheric partial pressures in water samples from springs in Clarke County, Virginia, 2003-2005.

Appendix 8. Summary of average chlorofluorocarbon-based model piston-flow apparent recharge dates, ages, and uncertainties in water samples from springs in Clarke County, Virginia, 2003-2005

Appendix 9. Summary of average chlorofluorocarbon-based model ratio apparent recharge dates, ages, and uncertainties in water samples from springs in Clarke County, Virginia, 2003-2005...

Appendix 10. Summary of average sulfur hexafluoride data in water samples from springs in Clarke County, Virginia, 2003-2005.

Appendix 11. Summary of tritium, dissolved helium, and dissolved neon data in water samples from springs in Clarke County, Virginia, 2003-2005

Appendix 12. Summary of apparent tritium/helium-3 ages in water samples from springs in Clarke County, Virginia, 2003-2005.

Appendix 13. Summary of oxygen $\left(\delta^{18} 0\right)$ and hydrogen $\left(\delta^{2} H\right)$ isotopic data in water samples from springs in Clarke County, Virginia, 2003-2005. 


\section{Figures}

1. Generalized geologic province map of Clarke County,

Virginia, and location of study area..

2. Generalized hydrogeologic sections across Clarke and

Frederick Counties, Virginia

3. Graphs showing average monthly precipitation for National Weather Service climatological stations $445851 \mathrm{Mt}$. Weather located in Loudoun County, Virginia, at an altitude of 1,720 feet above NGVD 29 and 449186 Winchester 7 SE located in Frederick County, Virginia, at an altitude of 680 feet above NGVD 29

4. Map showing average annual precipitation across Clarke County, Virginia, based on parameter-elevation regressions on independent slopes model (PRISM) ..................7

5. Generalized hydrogeologic units map of Clarke County, Virginia ...................................10

6. Graphic representation of joint types and bedding in folded rocks................................15

7. Aerial photograph showing large plunging fold in the Shenandoah River south of Calmes Neck in Clarke County, Virginia

8. Map showing location of Landsat lineament zones and sinkholes in Clarke County, Virginia

9. Boxplots showing summary statistics of well-construction and hydrologic characteristics of the hydrogeologic units in Clarke County, Virginia.

10-15. Maps showing-

10. Density of wells with reported well yields less than 5 gallons per minute in Clarke County, Virginia

11. Density of wells with reported well yields greater than 50 gallons per minute in Clarke County, Virginia ....................................................23

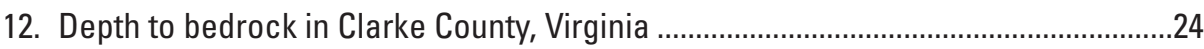

13. Depth to top of upper reported water-bearing zones in Clarke County, Virginia

14. Depth to top of lower reported water-bearing zones in Clarke County, Virginia

15. Location of streamflow gaging stations, springs, and wells in the long-term water monitoring network for Clarke County, Virginia..

16-18. Graphs showing-

16. Relation between daily water levels in wells $46 \mathrm{~W} 175$ and $46 \mathrm{~W} 179$ and quarterly standardized precipitation index at National Weather Service climatological station 449186 Winchester 7 SE, Virginia

17. Relation between daily water levels in wells $48 X 20$ and quarterly standardized precipitation index at National Weather Service climatological station $445851 \mathrm{Mt}$. Weather, Virginia.

18. Quarterly water levels from selected wells located in recharge and discharge areas of the Valley and Ridge and Blue Ridge Physiographic Provinces in Clarke County, Virginia

19. Map showing approximate altitudes and configurations of the water table determined from spring altitudes and water levels measured in wells, April 2003, Clarke County, Virginia.

20. Map showing approximate altitudes and configurations of the water table determined from spring altitudes and water levels measured in wells, October 2007, Clarke County, Virginia. 
21-23. Graphs showing-

21. Vertical hydraulic gradients in the Great Valley section of Clarke County, Virginia, between October 2002 and October 2008

22. Daily mean and quarterly discharges from selected springs in Clarke County, Virginia, between April 2003 and October 2008.

23. Relation between daily air temperature and precipitation at National Weather Service climatological station 449186 Winchester 7 SE and air and water temperatures at spring 46XS 8 and estavelle located 0.84 mi west of spring 46XS 8 in Clarke County, Virginia

24. Map showing location of groundwater areas and difference between minimum and maximum water levels for the period between October 2002 and July 2008 in Clarke County, Virginia

25. Graphs showing relation between daily mean discharge and percent of daily mean discharge at streamflow gaging station 01636316 Spout Run at Route 621 near Millwood, Virginia, and 46WS 1 Carter Hall and 46WS 22 Saratoga Springs in Clarke County, Virginia

26. Aerial photograph showing location of U.S. Geological Survey's Groundwater Resources Program fiber-optic distributed temperature sensing evaluation project site and two-dimensional display of temperature data showing thermal anomaly, Shenandoah River, Clarke County, Virginia

27. Graph showing fiber-optic distributed temperature sensing data showing thermal anomaly associated with streambed depression in

Shenandoah River, Clarke County, Virginia

28. Map showing apparent age and percentage of young water fraction for sampling sites in Clarke County, Virginia.

29. Graph showing atmospheric mixing ratios of chlorofluorocarbon-11, chlorofluorocarbon-12, chlorofluorocarbon-113, and sulfur hexafluoride for North American air and estimated monthly concentration of tritium in precipitation for Virginia.

30. Generalized conceptual hydrogeologic longitudinal section of the flow system in the Valley and Ridge Physiographic Province in Clarke County, Virginia, showing strike-parallel and cross-strike flow along faults

31. Generalized conceptual hydrogeologic longitudinal section of the flow system in the Blue Ridge Physiographic Province in Clarke County, Virginia

32. Graph showing relation between annual precipitation at National Weather Service climatological station 449186 Winchester 7 SE, Virginia, and effective recharge at streamflow gaging stations 01616100 Dry Marsh Run near Berryville, Virginia, and 01636316 Spout Run at Route 621 near Millwood, Virginia

33. Aerial photographs showing wet and drought conditions in 1996 and 2002, respectively, for the area along Route 7 west of Berryville, Virginia, where Dry Marsh Run flows from spring 46XS 8 into a swallet hole and wetland area

34. Aerial photographs showing wet and drought conditions in 1996 and 2002, respectively, for an area along Route 620 in Clarke County, Virginia, where groundwater overflows along bedding and joints in the carbonate rock during wet periods

35. Graphs showing relation between daily maximum water levels in well 46W175 and cumulative quarterly precipitation and snowfall at National Weather Service climatological station 449186 Winchester 7 SE, Virginia, 1998-2007 .61

36. Boxplots showing statistical distribution of daily maximum water levels 
37. Graphs showing relation among annual rates of precipitation at National Weather Service climatological station 449186 Winchester 7 SE, Virginia, mean streamflow and mean base flow at streamflow gaging stations 01616100 Dry Marsh Run near Berryville, Virginia, and 01636316 Spout Run at Route 621 near Millwood, Virginia

38. Schematic showing relation between watershed volume above the altitude of streamflow gaging station 01616100 Dry Marsh Run near Berryville in Clarke County, Virginia, and occurrence of dry wells.

\section{Tables}

1. Well-construction characteristics for the hydrogeologic units in Clarke County, Virginia.

2. Physical and geologic characteristics of the groundwater areas in Clarke County, Virginia.

3. Apparent ages and uncertainties from chlorofluorocarbons, sulfur hexafluoride, and tritium/helium-3 dating methods and percentage of young fraction in water samples from springs in Clarke County, Virginia, 2003-2005

4. Summary of effective recharge and streamflow partitioning rates for the groundwater areas and selected streamflow gaging stations in and adjacent to Clarke County, Virginia.

5. Summary of annual water budget components for the Dry Marsh Run and Spout Run Basins in Clarke County, Virginia, 2001-2007. . .57

6. Median rates of quarterly water-level recovery from the 1999-2002 drought for the groundwater areas in Clarke County, Virginia 


\section{Conversion Factors and Datum}

Inch/Pound to SI

\begin{tabular}{|c|c|c|}
\hline Multiply & By & To obtain \\
\hline \multicolumn{3}{|c|}{ Length } \\
\hline inch (in.) & 25.4 & millimeter (mm) \\
\hline foot $(\mathrm{ft})$ & 0.3048 & meter (m) \\
\hline mile (mi) & 1.609 & kilometer (km) \\
\hline \multicolumn{3}{|c|}{ Area } \\
\hline acre & 4,047 & square meter $\left(\mathrm{m}^{2}\right)$ \\
\hline acre & 0.4047 & hectare (ha) \\
\hline square mile $\left(\mathrm{mi}^{2}\right)$ & 259.0 & hectare (ha) \\
\hline square mile $\left(\mathrm{mi}^{2}\right)$ & 2.590 & square kilometer $\left(\mathrm{km}^{2}\right)$ \\
\hline \multicolumn{3}{|c|}{ Volume } \\
\hline gallon (gal) & 3.785 & liter (L) \\
\hline gallon (gal) & 0.003785 & cubic meter $\left(\mathrm{m}^{3}\right)$ \\
\hline million gallons (Mgal) & 3,785 & cubic meter $\left(\mathrm{m}^{3}\right)$ \\
\hline \multicolumn{3}{|c|}{ Flow rate } \\
\hline foot per day (ft/d) & 0.3048 & meter per day (m/d) \\
\hline cubic foot per second $\left(\mathrm{ft}^{3} / \mathrm{s}\right)$ & 0.02832 & cubic meter per second $\left(\mathrm{m}^{3} / \mathrm{s}\right)$ \\
\hline $\begin{array}{l}\text { cubic foot per second per square } \\
\text { mile }\left[\left(\mathrm{ft}^{3} / \mathrm{s}\right) / \mathrm{mi}^{2}\right]\end{array}$ & 0.01093 & $\begin{array}{l}\text { cubic meter per second per square } \\
\text { kilometer }\left[\left(\mathrm{m}^{3} / \mathrm{s}\right) / \mathrm{km}^{2}\right]\end{array}$ \\
\hline gallon per minute (gal/min) & 0.06309 & liter per second (L/s) \\
\hline gallon per day (gal/d) & 0.003785 & cubic meter per day $\left(\mathrm{m}^{3} / \mathrm{d}\right)$ \\
\hline million gallons per day (Mgal/d) & 0.04381 & cubic meter per second $\left(\mathrm{m}^{3} / \mathrm{s}\right)$ \\
\hline inch per year (in/yr) & 25.4 & millimeter per year (mm/yr) \\
\hline \multicolumn{3}{|c|}{ Specific capacity } \\
\hline $\begin{array}{l}\text { gallon per minute per foot } \\
\text { [(gal/min)/ft)] }\end{array}$ & 0.2070 & $\begin{array}{l}\text { liter per second per meter } \\
{[(\mathrm{L} / \mathrm{s}) / \mathrm{m}]}\end{array}$ \\
\hline \multicolumn{3}{|c|}{ Hydraulic conductivity } \\
\hline foot per day (ft/d) & 0.3048 & meter per day (m/d) \\
\hline \multicolumn{3}{|c|}{ Hydraulic gradient } \\
\hline foot per mile (ft/mi) & 0.1894 & meter per kilometer (m/km) \\
\hline \multicolumn{3}{|c|}{ Transmissivity } \\
\hline foot squared per day $\left(\mathrm{ft}^{2} / \mathrm{d}\right)$ & 0.09290 & meter squared per day $\left(\mathrm{m}^{2} / \mathrm{d}\right)$ \\
\hline
\end{tabular}

SI to Inch/Pound

\begin{tabular}{lll}
\hline \multicolumn{1}{c}{ Multiply } & By & \multicolumn{1}{c}{ To obtain } \\
\hline & Length & \\
millimeter $(\mathrm{mm})$ & 0.03937 & inch (in.) \\
meter $(\mathrm{m})$ & 3.281 & foot $(\mathrm{ft})$ \\
kilometer $(\mathrm{km})$ & 0.6214 & mile (mi) \\
& Volume & \\
liter (L) & 3.785 & gallon (gal) \\
cubic centimeter $\left(\mathrm{cm}^{3}\right)$ & 0.06102 & cubic inch $\left(\mathrm{in}^{3}\right)$ \\
\hline
\end{tabular}


Temperature in degrees Celsius $\left({ }^{\circ} \mathrm{C}\right)$ may be converted to degrees Fahrenheit $\left({ }^{\circ} \mathrm{F}\right)$ as follows:

$$
{ }^{\circ} \mathrm{F}=\left(1.8 x^{\circ} \mathrm{C}\right)+32
$$

Vertical coordinate information is referenced to the National Geodetic Vertical Datum of 1929 (NGVD 29).

Horizontal coordinate information is referenced to the North American Datum of 1983 (NAD 83).

Altitude, as used in this report, refers to distance above the vertical datum.

Specific conductance is given in microsiemens per centimeter at 25 degrees Celsius $\left(\mu \mathrm{S} / \mathrm{cm}\right.$ at $\left.25^{\circ} \mathrm{C}\right)$.

Concentrations of chemical constituents are given in milligrams per liter (mg/L).

\section{Acronyms and Abbreviations}

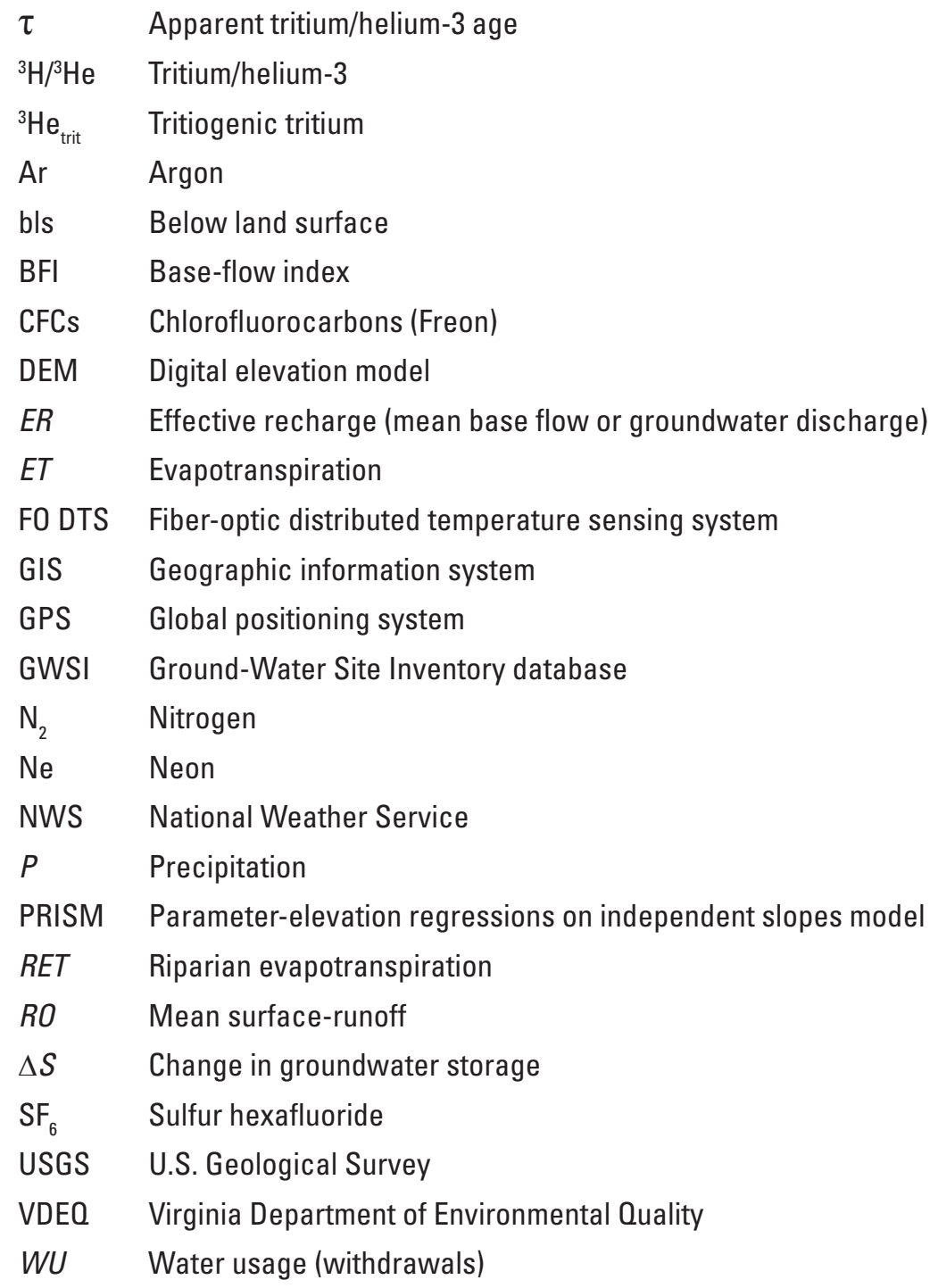





\title{
Hydrogeology and Groundwater Availability in Clarke County, Virginia
}

\author{
By David L. Nelms and Roger M. Moberg, Jr.
}

\section{Abstract}

The prolonged drought between 1999 and 2002 drew attention in Clarke County, Virginia, to the quantity and sustainability of its groundwater resources. The groundwater flow systems of the county are complex and are controlled by the extremely folded and faulted geology that underlies the county. A study was conducted between October 2002 and October 2008 by the U.S. Geological Survey, in cooperation with Clarke County, Virginia, to describe the hydrogeology and groundwater availability in the county and to establish a long-term water monitoring network. The study area encompasses approximately 177 square miles and includes the carbonate and siliciclastic rocks of the Great Valley section of the Valley and Ridge Physiographic Province and the metamorphic rocks of the Blue Ridge Physiographic Province (Blue Ridge).

High-yielding wells generally tend to cluster along faults, within lineament zones, and in areas of tight folding throughout the county. Water-bearing zones are generally within 250 feet (ft) of land surface; however, median depths are slightly deeper for the hydrogeologic units of the Blue Ridge than for those of the Great Valley section of the county. Total water-level fluctuations between October 2002 and October 2008 ranged from 2.86 to $87.84 \mathrm{ft}$ across the study area, with an average of $24.15 \mathrm{ft}$. Generally, water-level fluctuations were greatest near hydrologic divides, in isolated elevated areas, and in the Opequon Creek Basin. Seasonally, waterlevel highs occur in the early spring at the end of the major groundwater recharge period and lows occur in late autumn when evapotranspiration rates begin to decrease. An overall downward trend in water levels between 2003 and 2008, which closely follows a downward trend in annual precipitation over the same period, was observed in a majority of wells in the Great Valley and in some of the wells in the Blue Ridge. Water-level fluctuations in the Blue Ridge tend to follow current meteorological conditions, and seasonal highs and lows tend to shift in response to the current conditions.
Springs generally are present along faults and fold axes, and discharges for the study period ranged from dry to 10 cubic feet per second. A similar downward trend in discharges correlates with the trend in water levels and is indicative of an aquifer system that, over time, drains to a base level controlled by springs and streams. Point discharge from springs can occur as the start of flows of streams and creeks, along banks, and as discrete discharge through streambeds in the Great Valley. For the most part, streams, creeks, and rivers in the Great Valley function as aqueducts. Springs in the Blue Ridge have relatively low discharge rates, have small drainage areas, and are susceptible to current meteorological conditions.

Estimates of effective groundwater recharge from 2001 to 2007 ranged from 6.4 to 23.0 inches per year (in/yr) in the Dry Marsh Run and Spout Run Basins with averages of 11.6 and $11.9 \mathrm{in} / \mathrm{yr}$, respectively. Base flow accounted for between 80 and 97 percent of mean streamflow and averaged about 90 percent in these basins. The high base-flow index values (percent of streamflow from base flow) in the Dry Marsh Run and Spout Run Basins indicate that groundwater is the dominant source of streamflow during both wet and drought conditions. Between 46 and 82 percent of the precipitation that fell on the Dry Marsh Run and Spout Run Basins from 2001 to 2007 was removed by evapotranspiration, and an average of approximately 30 percent of the precipitation reached the water table as effective recharge. The high permeability of the rocks and low relief in these basins are not conducive for runoff; therefore, on average, only about 3 to 4 percent of the precipitation becomes runoff.

Groundwater flow systems in the county are extremely vulnerable to current climatic conditions. Successive years of below-average effective recharge cause declines in water levels, spring discharges, and streamflows. However, these systems can recover quickly as effective recharge increases, especially in the Dry Marsh Run area. Effective recharge tends to increase as precipitation increases, but lack of precipitation, especially snow, during the critical recharge periods can have an effect on the amount of recharge. The combination of a lack of precipitation, large water-level fluctuations, depths to waterbearing zones, and hydrogeologic setting is the most probable explanation of the well failures during the recent drought. 


\section{Introduction}

The Northern Shenandoah Valley is underlain by karst and fractured-rock aquifers that are increasingly being relied upon to supply water to local communities and individual residences. This is an area with an expanding economy and a growing population, and, to meet future water needs, these aquifers are likely to be developed further to supplement current withdrawals. The prolonged drought between 1999 and 2002 drew attention in Clarke County, VA, to the quantity and sustainability of the groundwater resources. More than 20 wells in Clarke County reportedly went dry during this drought, which brought into question whether these failures were related to increased demand or the result of natural fluctuations of the water table. An improved understanding of the complex aquifer systems in the county is required to effectively develop and manage them as sustainable water supplies because 54 percent of water use in the county is obtained from groundwater for domestic purposes (Hutson and others, 2004). In order to assess current and future hydrologic conditions within the county, a long-term monitoring network was established to measure water levels, streamflows, and spring discharges. Hydrogeologic information collected during this investigation has been used to address questions about (1) the quantity of water available for use, (2) the effects of increased pumpage on groundwater levels and instream flows, and (3) the quality of the groundwater supply and its vulnerability to current and potential future sources of contamination.

Prior to this investigation, the major water-resources focus in the county had been protection of water quality. Information from this report on water availability coupled with ongoing water-quality protection efforts will assist the county in meeting requirements outlined in the county's comprehensive plan, which includes water resources, groundwater resources, and surface-water resources components. In addition, a long-term monitoring network will provide information necessary to assess future hydrologic conditions and to evaluate effects of increasing water-supply demands in the future.

\section{Purpose and Scope}

This report describes the hydrogeology and groundwater availability of the karst and fractured-rock aquifer systems in Clarke County, VA, and provides hydrogeologic information that can be used to guide the development and management of these important water resources. Water budgets that include effective groundwater recharge are presented for the Dry Marsh and Spout Run Basins for 2001-2007. This report also includes data for groundwater levels, spring discharges, and streamflows collected as part of a long-term water-resources monitoring network and data for apparent groundwater ages.

\section{Description of Study Area}

The study area includes all of Clarke County, VA (fig. 1). The county is located within the Valley and Ridge and Blue Ridge Physiographic Provinces (Valley and Ridge and Blue Ridge, respectively) of Virginia (Fenneman, 1938), at the northern end of the Shenandoah Valley, about 75 miles (mi) west of Washington, DC. Clarke County is bordered by Jefferson County, WV, to the north, Warren County to the south, Fauquier and Loudoun Counties to the east, and Frederick County to the west. Clarke County encompasses about 177 square miles $\left(\mathrm{mi}^{2}\right)$ and had a population of 12,652 in 2000. The Valley and Ridge part of the county commonly is referred to as the Great Valley section (fig. 1). The Great Valley section of the central Appalachian Valley and Ridge Province extends nearly 1,000 mi from southern New York to central Alabama (Yager and others, 2008). The Great Valley section within the study area, locally known as the Shenandoah Valley, is predominantly underlain by soluble carbonate rocks that form karst features such as sinkholes, caves, estavelles, swallet holes, and sinking streams. Less soluble siliciclastic rocks (sandstone, siltstone, and shale) underlie the western edge of the Great Valley section of the county. The Great Valley section of the county encompasses two major basins within the Potomac River Watershed: Opequon Creek to the west and the Shenandoah River on the east. The drainage divide between these two basins is present in an area of the county that is frequently referred to as the Limestone Ridge. Formal definition of this area is necessary because of its importance to the underlying groundwater flow systems. The Limestone Ridge is delineated as the area higher than the contour for $630 \mathrm{ft}$ above NGVD 1929 (fig. 1).

The most resistant to weathering and oldest rocks in the study area are the metamorphic rocks that underlie the Blue Ridge in the eastern part of Clarke County (fig. 1). The Blue Ridge is a mountainous terrain with steep slopes and the highest land-surface altitudes within the study area.

\section{Conceptual Model of Groundwater Flow}

The groundwater flow systems in the Valley and Ridge and Blue Ridge are complex. Flow through and storage within these systems are controlled by the topography and underlying geology of the respective provinces. The two hydrogeologic sections shown in figure 2 depict a conceptual model of groundwater flow through both of these systems. In both areas, the rocks are highly deformed by folding, faulting, and weathering processes. In order to depict the range in depth where most of the wells are drilled, the steepness of the geologic structures is over-exaggerated, but the difference in dip between the west and east limbs of the Massanutten synclinorium is preserved in these sections. The conceptual relations among karst features and geologic structure are illustrated in sections A-A' and B-B'. Groundwater flow directions generally follow the topography and are controlled by the geologic structure. 


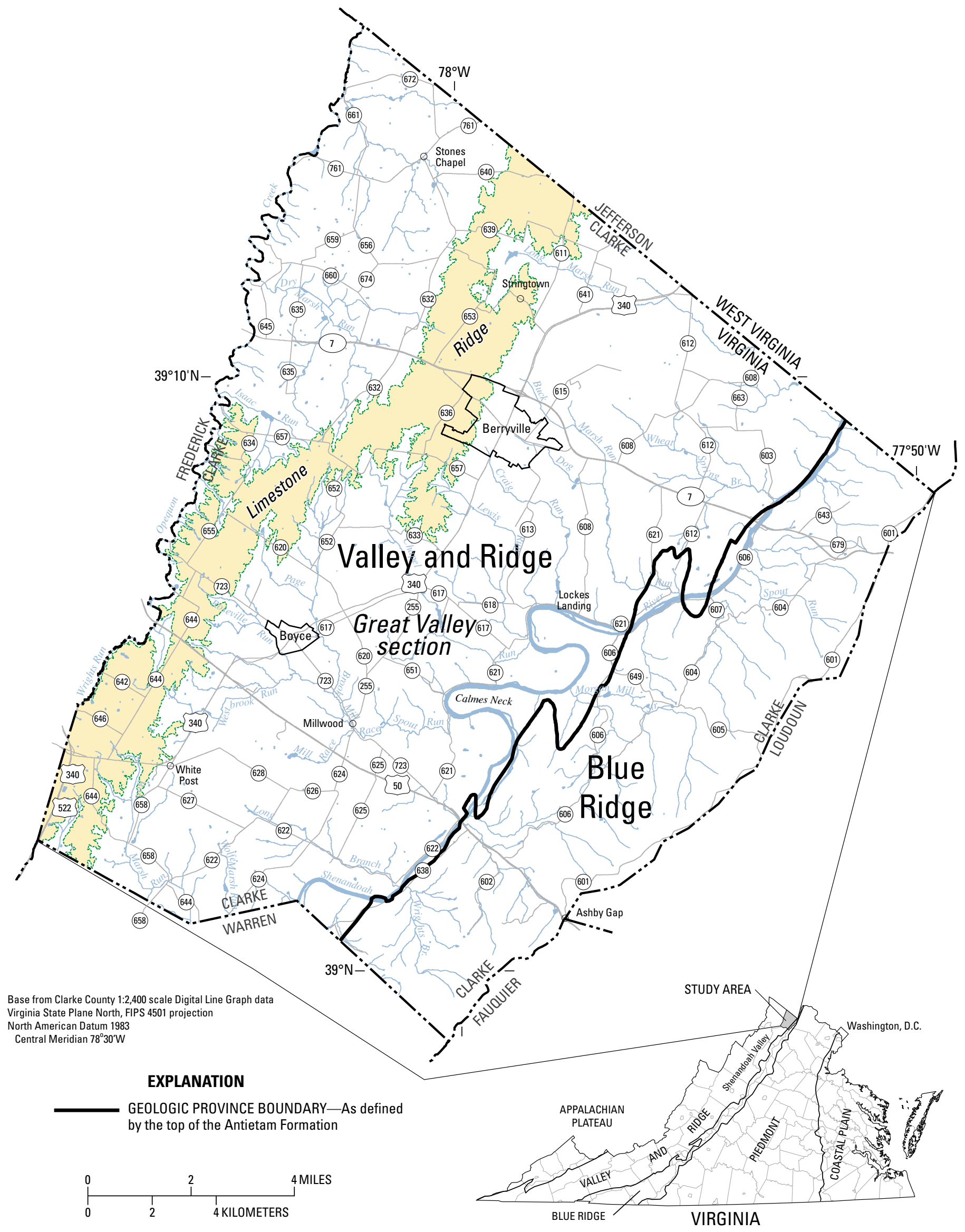

Figure 1. Generalized geologic province map of Clarke County, Virginia, and location of study area. 


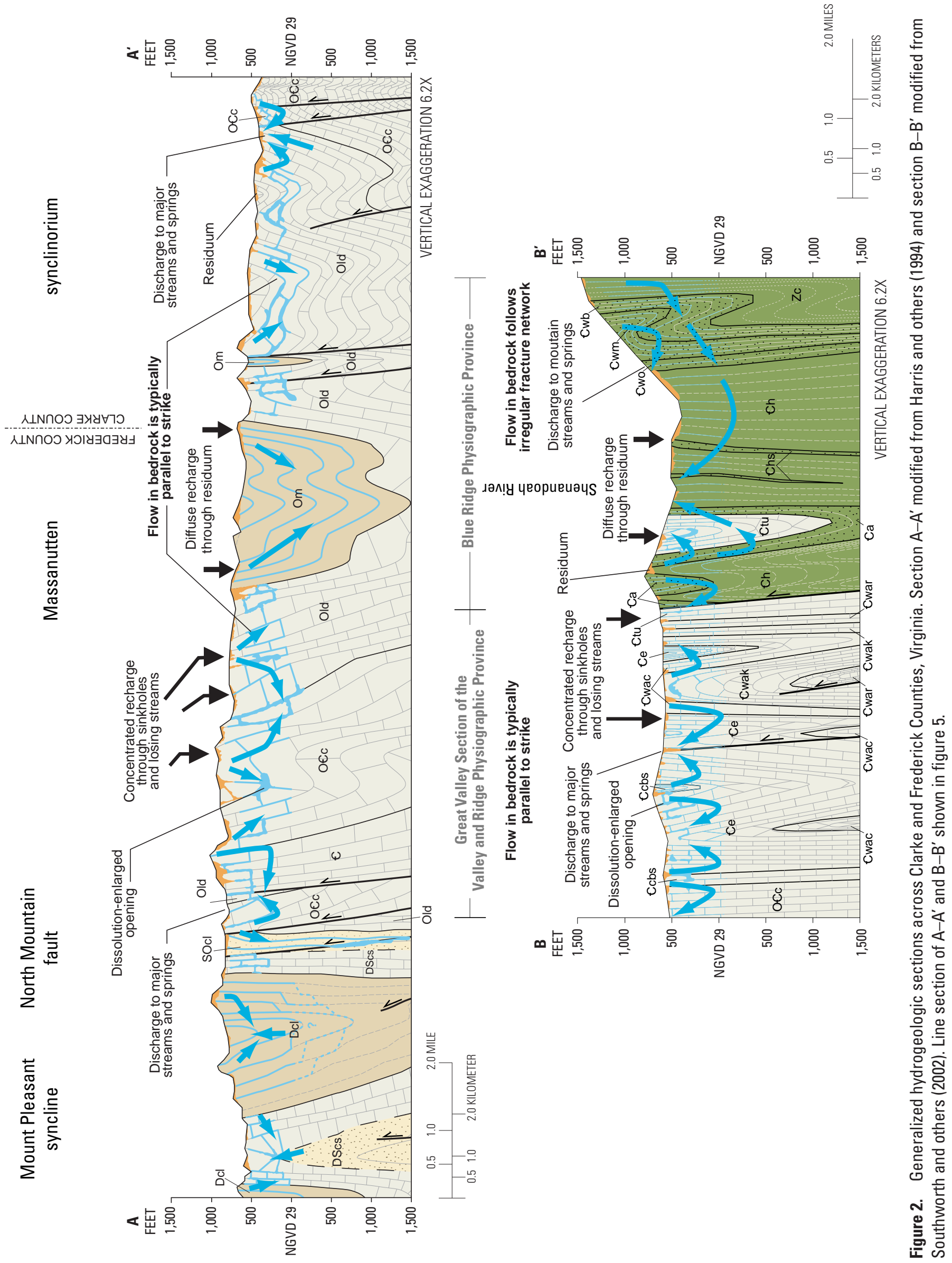




\section{EXPLANATION}

\section{CORRELATION OF HYDROGEOLOGIC UNITS}

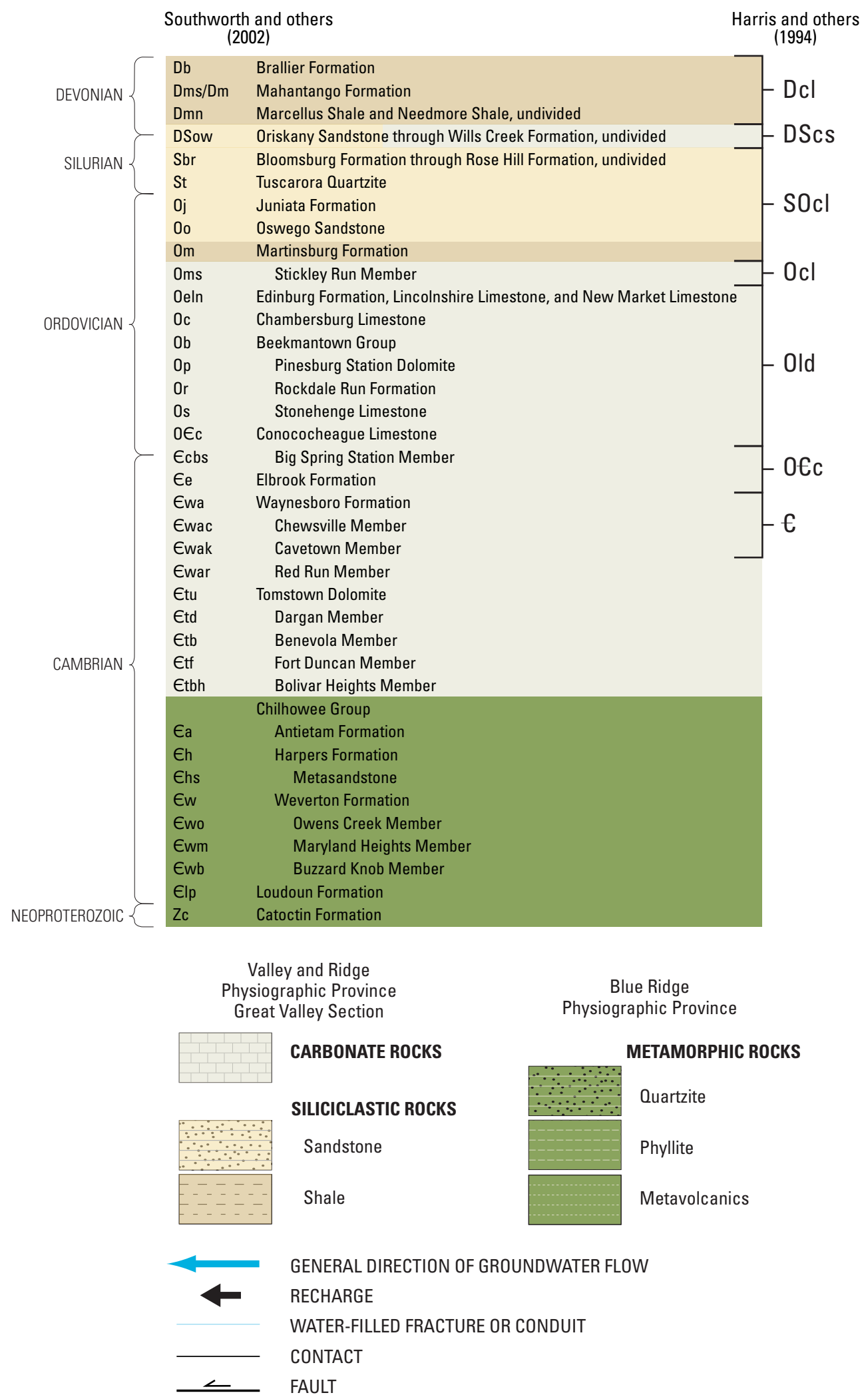

Figure 2. Generalized hydrogeologic sections across Clarke and Frederick Counties, Virginia. Section A-A' modified from Harris and others (1994) and section B-B' modified from Southworth and others (2002). Line section of $A-A^{\prime}$ and $B-B^{\prime}$ shown in figure 5.-Continued 


\section{Climate}

Climatic data for the region were obtained from National Weather Service (NWS) climatological station 445851 Mt. Weather, which is located to the east in Loudoun County at an altitude of 1,720 ft above NGVD 29, and from NWS climatological station 449186 Winchester 7 SE, which is located to the west in Frederick County at an altitude of $680 \mathrm{ft}$ above NGVD 29 (fig. 4). The periods of record for these two stations are 103 and 102 years for temperature data and 104 and 101 years for precipitation data, respectively (National Oceanic and Atmospheric Administration, 2006). The normal values are based on the NWS's current normal climatological period from 1971 to 2000. The mean annual air temperature at the Mt. Weather station is 10.6 degrees Celsius $\left({ }^{\circ} \mathrm{C}\right)$ with the coldest month being January $\left(-1.8^{\circ} \mathrm{C}\right)$ and the warmest July $\left(22.3^{\circ} \mathrm{C}\right)$. The colder periods of the year are between November and April, and the warmer periods are between May and October. The mean annual air temperature at the Winchester $7 \mathrm{SE}$ station is $11.7^{\circ} \mathrm{C}$ with the coldest month being January $\left(-0.9^{\circ} \mathrm{C}\right)$ and the warmest July $\left(23.7^{\circ} \mathrm{C}\right)$. The colder periods of the year for air temperature also are between November and April, and the warmer periods are between May and October.

Average annual precipitation at the Mt. Weather station is 43.3 inches (in.) During an average year, average annual precipitation would be highest in May (4.5 in.) and lowest in February (2.5 in.). The average annual precipitation of $39.1 \mathrm{in.}$ at the Winchester $7 \mathrm{SE}$ station is about 4 in. lower than annual precipitation at the Mt. Weather station. In an average year, monthly precipitation totals are highest in June (4.1 in.) and lowest in February (2.4 in.) at the Winchester 7 SE station. Although precipitation is relatively evenly distributed throughout an average year, average monthly precipitation tends to be lower for October through April than for May through September (fig. 3).

A grid of average annual precipitation interpolated from the parameter-elevation regressions on independent slopes model (PRISM) for Clarke County, VA, is shown in figure 4. The normal values are based on the NWS's current normal climatological period from 1971 to 2000. PRISM is an analytical model that generates gridded estimates of annual precipitation from point data at NWS climatological stations and a digital elevation model (DEM) (Di Luzio and others, 2008). The PRISM grid estimates that average annual precipitation ranges from 38.9 to 42.6 in. across Clarke County. The higher values illustrate the orographic effect on precipitation of the elevated areas of the Blue Ridge east of the Shenandoah River. The lower values also illustrate orographic effects caused by mountain ranges to the west in western Frederick County, VA, and WV. The lowest average annual precipitation is present in the western parts of the county and just east of Berryville. These two areas are the northern extent of a rain shadow centered on Harrisonburg, VA, which is caused by the mountain ranges to the west.

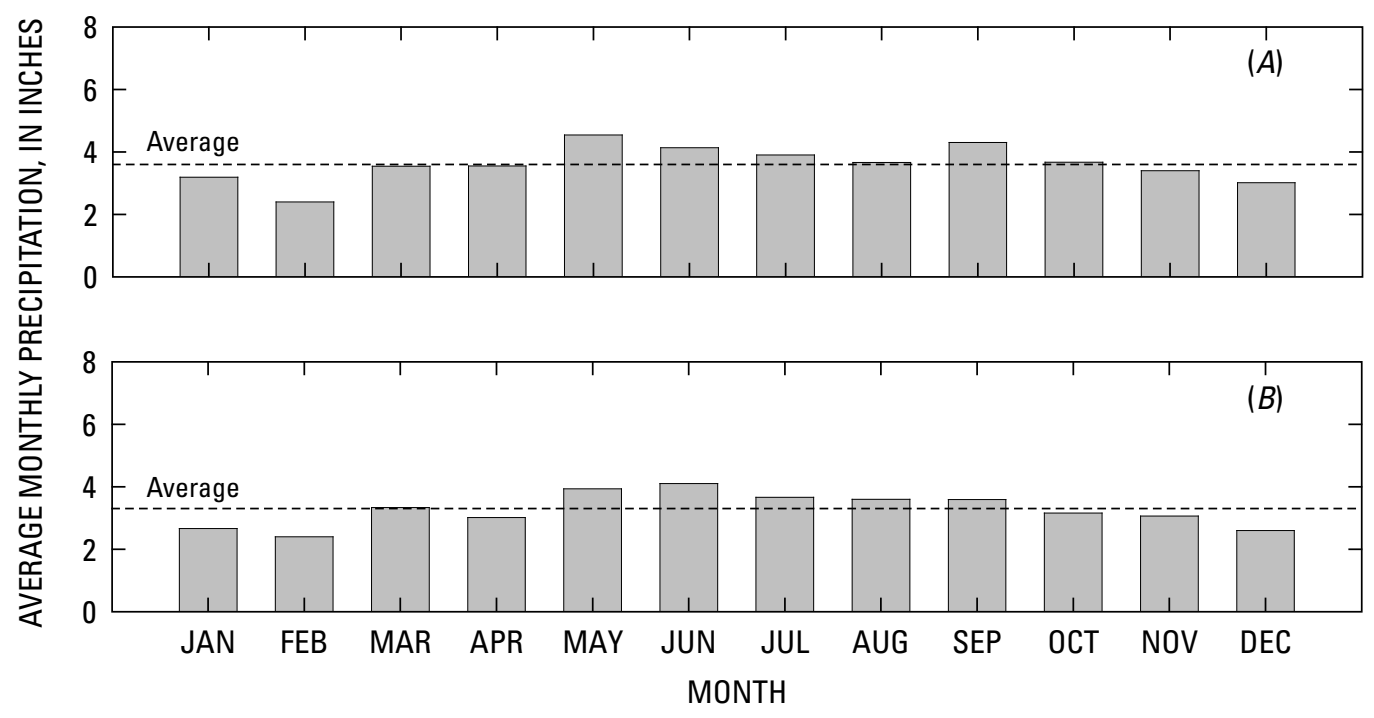

Figure 3. Average monthly precipitation for National Weather Service climatological stations (A) 445851 Mt. Weather located in Loudoun County, Virginia, at an altitude of 1,720 feet above NGVD 29 and (B) 449186 Winchester 7 SE located in Frederick County, Virginia, at an altitude of 680 feet above NGVD 29. The normal values are based on the National Weather Service's current normal climatological period from 1971 to 2000. 

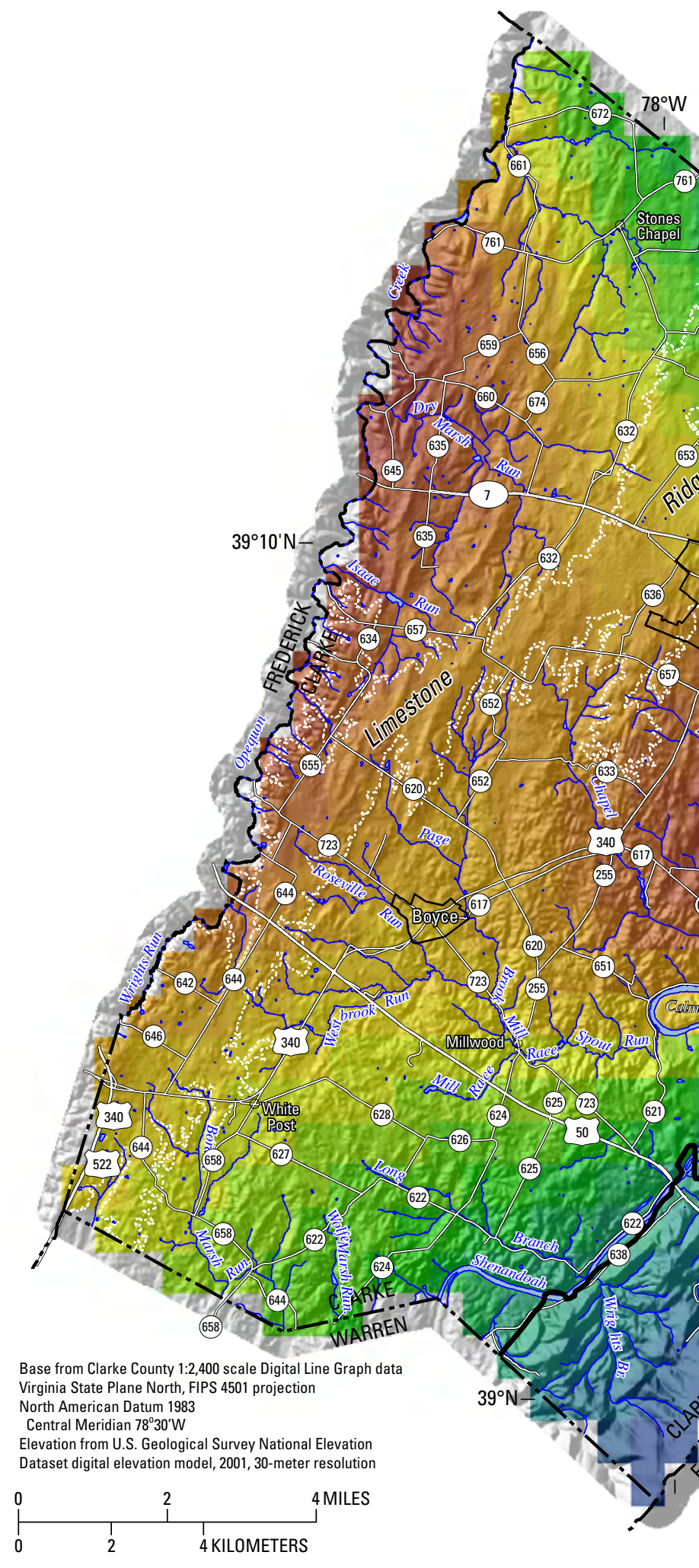


\section{Well- and Spring-Numbering System}

A unique USGS identifier was assigned to each well (appendix 1) and spring (appendix 2) for this study, for the purpose of storing well-construction and site information in the Ground-Water Site Inventory (GWSI) database maintained by the USGS. These USGS identifiers are based on the Virginia coordinate grid number of the USGS standard series 7.5-minute topographic quadrangle in which the well is located, and the chronological order in which the well was entered. For example, the USGS number 46W175 corresponds to the 175th well entered by the USGS in the area covered by the Boyce quadrangle, which has a Virginia coordinate grid number of $46 \mathrm{~W}$. Springs (appendix 2) are numbered in a similar manner with the addition of 'S' after the Virginia coordinate grid number of the USGS standard series 7.5-minute topographic quadrangle.

\section{Previous Investigations}

Cady (1936) conducted the first comprehensive study of the groundwater resources of the Shenandoah Valley; Clarke County, however, was not included. The first comprehensive investigation of the county's groundwater resources was included in Cady (1938), in which he noted that (1) "the limestone wells are exceptionally successful," (2) the "spring waters" were susceptible to contamination in "settled areas," and (3) a large number of springs east of Berryville either "became weak or went dry" in the early 1930s, which was the initial period of a prolonged drought. Hack (1965) provides a detailed explanation of the geomorphology of the Shenandoah Valley of Virginia and West Virginia. A regional investigation from Maine to Virginia by Cederstrom (1972) suggested that wells constructed for high capacity use are the best indicators of the potential of the rocks to yield water. Trainer and Watkins (1975) conducted a geohydrologic reconnaissance of the upper Potomac River Basin that focused on the hydrologic characteristics of the rocks, base flow and low flow of streams, water management, and chemical quality of groundwater. Hubbard (1983) mapped selected karst features in the northern Valley and Ridge of Virginia. Rader and others (1996) compiled the geology of the Lord Fairfax Planning District at a scale of 1:100,000. Rader and Gathright (2001) and Rader and others $(2001,2003)$ compiled the geology of the northern Virginia area, including Clarke County, at a 1:100,000 scale. Doctor and others (2008) provided detail of the bedrock structural controls on the occurrence of sinkholes and springs in the northern Great Valley karst and also suggested that deep karst development may have been caused by rising fluids under hypogenic (confined) conditions in the geologic past. Yager and others (2008) developed a finite-element model for the Shenandoah Valley of Virginia and West Virginia that simulated groundwater flow in the folded, fractured sedimentary rocks by specifying variable directions of the hydraulic conductivity tensor in order to correspond with changes in the strike and dip of bedrock across the valley.

Several investigations specifically dealt with the geology and hydrology of Clarke County. Edmundson and Nunan (1973) mapped the geology of the Berryville, Stephenson, and Boyce quadrangles, and Gathright and Nystrom (1974) mapped the geology of the Ashby Gap quadrangle. A soil survey of the county, conducted by the U.S. Department of Agriculture, noted sinkholes (Edmonds and Stiegler, 1982). Schnabel Engineering Associates (1983) evaluated the hydrogeology of spring 46WS 3 (Prospect Hill Spring) and provided recommendations for protecting this water source by establishing land-use restriction zones and an observation-well network. Jones (1987) conducted an overview of groundwater resources in the county for the Lord Fairfax Planning District Commission, which mainly focused on the carbonate aquifers. In addition, Jones (1987) conducted dye-tracer tests to help delineate the drainage basin for spring 46WS 3 (Prospect Hill Spring). The influence of geology and agriculture on groundwater quality was studied by LoCastro (1988) as part of a Master's Thesis at the University of Virginia. Hubbard (1990) mapped the geology, lineaments, and sinkholes in the county at a scale of 1:50,000. Wright (1990) studied the county's groundwater hydrology and quality. Jones (1987), Hubbard (1990), and Wright (1990) noted that groundwater flow in the carbonate aquifers is a mix of diffuse- and conduit-flow conditions; flow in the Blue Ridge is along irregular fracture patterns in the rock, and rapid flow is through the overburden to springs and streams in response to the steep terrain. Wright (1990) also noted that fecal-bacteria contamination was detected at about 40 percent of the sites sampled during his study. Ross and others (1992) evaluated household water quality in the county as part of the Virginia Cooperative Extension's waterquality testing program at Virginia Polytechnic Institute and State University. Recent studies have focused in detail on the occurrence and sources of fecal bacteria contamination in local springs and basins (Hagedorn and others, 1998). 


\section{Hydrogeology}

The geology of Clarke County is the main control on the occurrence and flow of groundwater. The county is characterized by karst and fractured-rock aquifer systems. The karst terrains of the Great Valley section of the Valley and Ridge are underlain by Lower Cambrian to Middle Ordovician limestone and dolostone bedrock, which are mantled by unconsolidated regolith material of varying thickness. The bedrock is variably fractured, folded, and faulted (Harlow and others, 2005), and the regolith material consists of residuum (weathered bedrock) and alluvium (stream deposits). Jones (1987) and Wright (1990) stated that the karst aquifer systems exhibit both conduit- and diffuse-flow conditions, and the occurrence and movement of groundwater is probably controlled by both karst and fractured-rock features. A mantle of unconsolidated regolith material overlies the siliciclastic rocks of the Upper Ordovician Martinsburg Formation in the western part of the county and the Neoproterozoic to Lower Cambrian metamorphic rocks of the Blue Ridge. The regolith in these areas tends to vary less in thickness than in the karst areas. Fractured-rock aquifers in these areas control the occurrence of groundwater, and water generally moves under diffuse-flow conditions.

\section{Geology}

The rocks in Clarke County were folded and faulted during the late Paleozoic Alleghanian orogeny about 300 million years ago. The terrain is a direct reflection of the underlying geology. Generally, the Great Valley section is a gently to moderately rolling terrain with low relief. Sinkholes, sinking streams, dry stream channels, caves, and springs are common in the karst terrain (Wright, 1990; Harlow and others, 2005). The areas underlain by the low permeability shale and siltstone of the Martinsburg Formation exhibit highly dissected drainage patterns. The mountainous terrain of the Blue Ridge formed in response to the resistant nature of the underlying metamorphic rocks (Hack, 1965).

\section{Hydrogeologic Units}

Clarke County can be subdivided into hydrogeologic units based on the mapped geologic formations and hydraulic properties of the rocks (fig. 5). In general, these hydrogeologic units also can be grouped based on gross lithology or rock type:

Carbonate-limestone and dolostone; Metamorphic — metavolcanic and metasedimentary rocks; and Siliciclastic—sandstone, siltstone, and shale.

The hydrogeologic characteristics vary among these units and between the major rock type groupings. Descriptions of the individual hydrogeologic units are provided below. The age and major rock-type grouping are included in the respective report section, and the map symbol used to identify the respective hydrogeologic unit in figure 5 is provided in the text.

\section{Carbonate Rock Unit}

The carbonate rock unit consists of dolostone, shale, limestone, and sandstone of the Lower Cambrian Tomstown and Waynesboro Formations; dolostone, dolomitic limestone, shale, and calcareous siltstone of the Middle and Upper Cambrian Elbrook Formation; laminated limestone, dolomitic limestone, dolostone, and calcareous sandstone of the Upper Cambrian and Lower Ordovician Conococheague Formation including the Big Spring Station Member; dolostone, limestone, and chert of the Lower Ordovician Stonehenge Limestone, the Lower and Middle Ordovician Rockdale Run Formation, and Pinesburg Station Dolomite of the Beekmantown Group; and limestone and shale of the Middle Ordovician New Market Limestone, Lincolnshire Limestone, Edinburg Formation, and Chambersburg Limestone (fig. 5). The combined thickness of the carbonate rock unit is approximately 11,500 ft (Hubbard, 1990).

\section{Tomstown Dolomite}

The Lower Cambrian Tomstown Dolomite (Ct) represents the oldest carbonate unit in Clarke County and was formed in deep shelf to peritidal-type environments (Southworth and others, 2002). The Tomstown Dolomite has been divided into four members by Brezinski (1992): Bolivar Heights, Fort Duncan, Benevola, and Dargan Members (fig. 5). These members have only been mapped in the northeastern part of the county, and only the contacts of the undivided Tomstown Dolomite are shown on figure 5 for the remainder of the county. The overall thickness of the Tomstown is from 1,100 to $1,200 \mathrm{ft}$ (Hubbard, 1990).

The Bolivar Heights Member (Ctbh) consists of darkgray limestone with tan dolomitic burrows. The limestone is thin bedded and medium grained, and bioturbation is more prevalent upsection. A very light-gray to tan, mylonitic marble is present at the base and has been termed the Keedysville marble bed (Brezinski, 1992) that extends more than $60 \mathrm{mi}$ from east of Berryville, VA, to south-central PA along a stratigraphically restricted fault zone (Brezinski and others, 1996). The Fort Duncan Member (Ctf) consists of a dark-gray, bioturbated dolomite that is thick bedded. Salterella, which is a cone-shaped fossil, is present in this member (Southworth and others, 2002). The Benevola Member (Ctb) consists of light-gray, sugary dolomite. The dolomite is of high purity, and bedding is very thick to massive (Southworth and others, 2002). The Dargan Member (Ctd) consists of alternating intervals of light-gray, bioturbated and laminated dolomite in the lower part. Interbeds of light-gray, bioturbated and oolitic dolomite and laminated limestone and silty dolomite are present in the upper part (Southworth and others, 2002). 


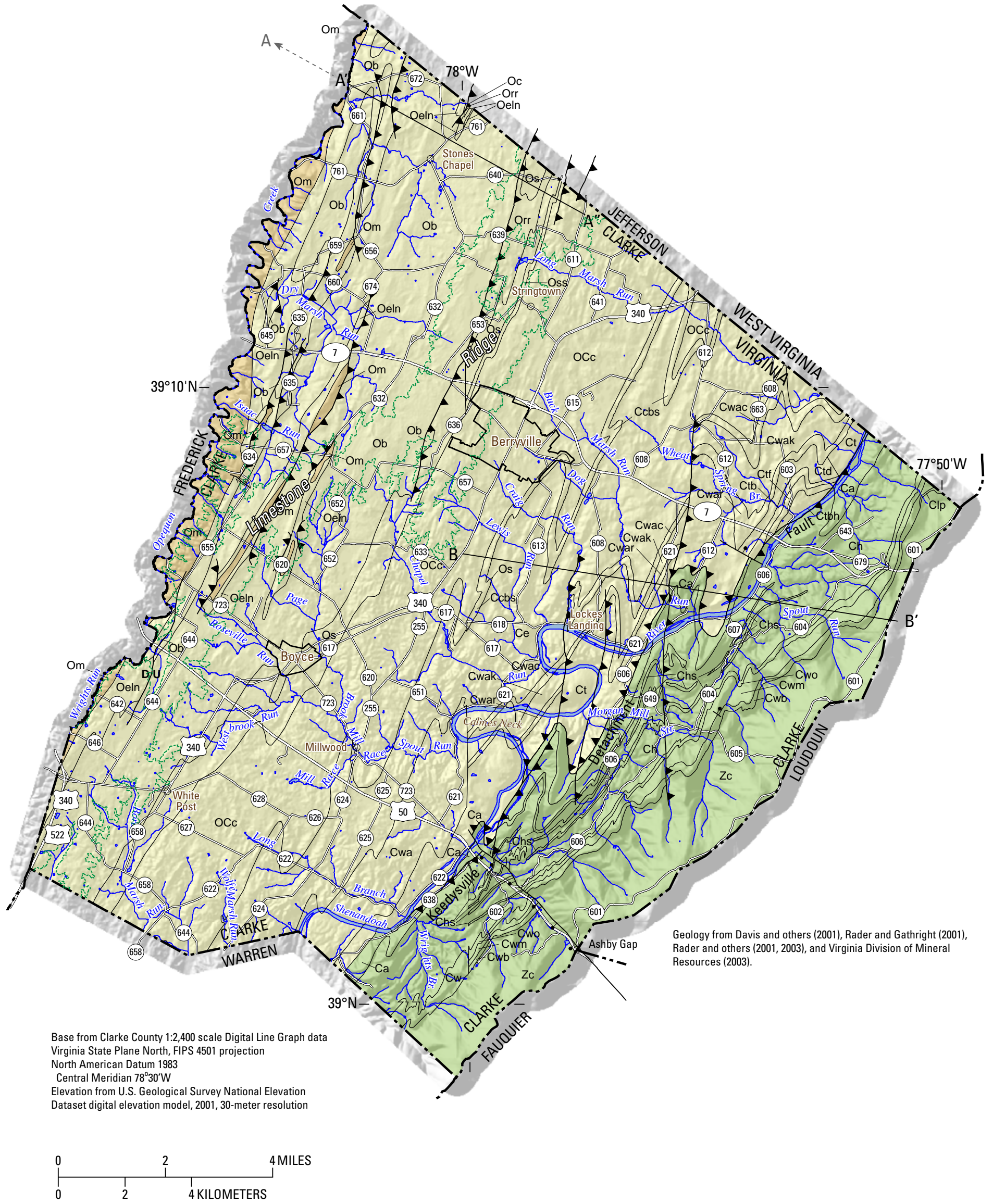

Figure 5. Generalized hydrogeologic units map of Clarke County, Virginia. 


\section{EXPLANATION OF MAP SYMBOLS}

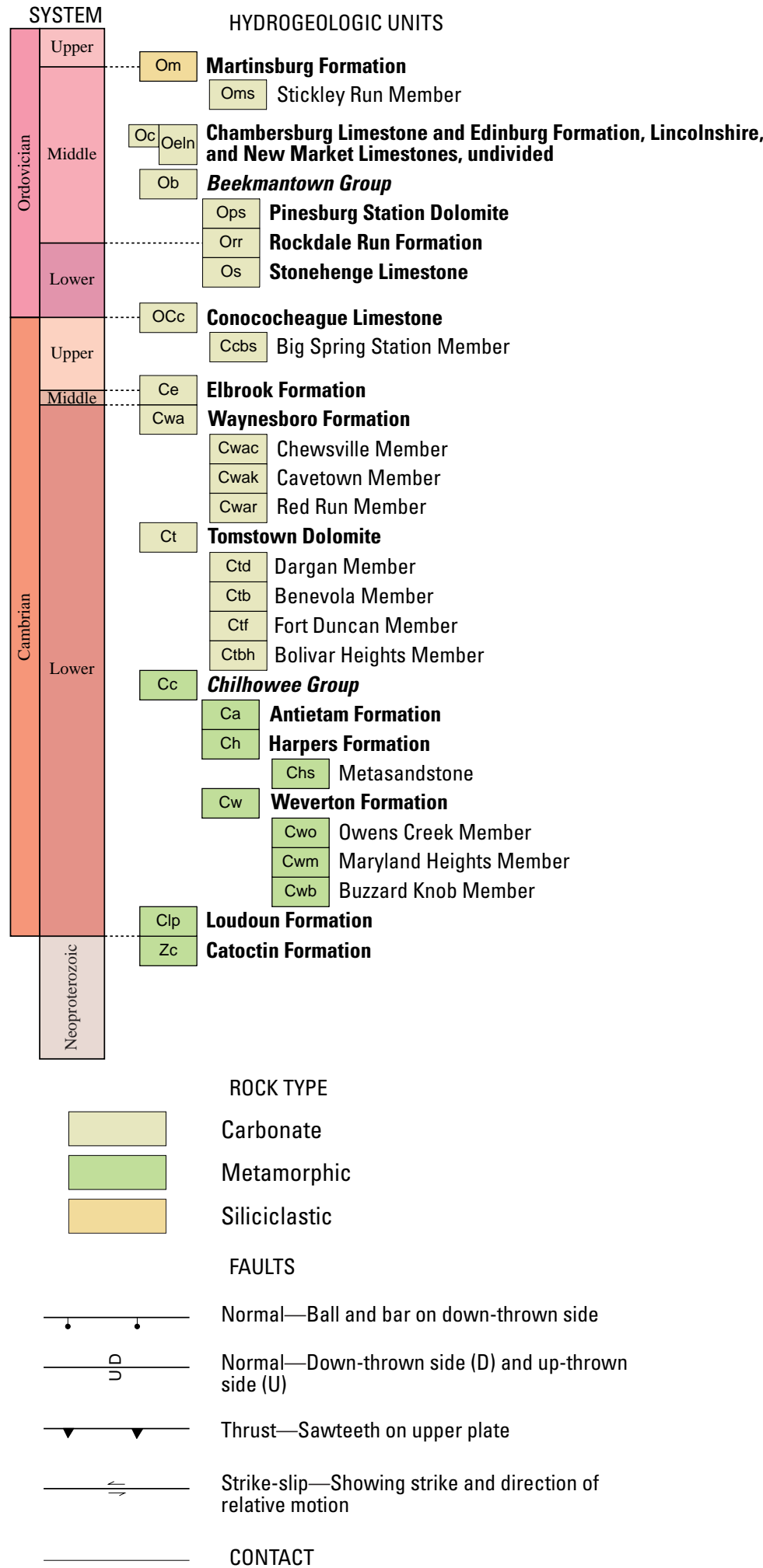

Figure 5. Generalized hydrogeologic units map of Clarke County, Virginia.

-Continued 


\section{Waynesboro Formation}

The Lower Cambrian Waynesboro Formation (Cwa) has been divided into three members by Brezinski (1992): Red Run, Cavetown, and Chewsville Members (fig. 5). The sandstone of the lower Red Run and upper Chewsville Members forms low hills. The carbonate rock of the Cavetown Member underlies swales between these hills (Southworth and others, 2002). These units are not mapped in the southeastern part of Clarke County, and only the contacts of the undivided Waynesboro Formation are shown in figure 5 (Virginia Division of Mineral Resources, 2003). The overall thickness of the Waynesboro Formation is 1,300 ft (Hubbard, 1990).

The Red Run Member (Cwar) consists of interbeds of light-gray, fine-grained, calcareous sandstone; medium- to dark-gray laminated, ribbony, sandy dolomitic limestone; and light-olive-gray, silty, calcareous shale (Southworth and others, 2002). The Cavetown Member (Cwak) consists of medium- to dark-gray, thick-bedded, massive limestone and bioturbated dolomite in the lower part. The middle part consists of bioturbated, dolomitic limestone and dolomite and thin calcareous sandstone and shale. The upper part consists of thick-bedded, bioturbated dolomite with laminated ribbony dolomite. Typically, the Cavetown Member is not well exposed (Southworth and others, 2002). The Chewsville Member (Cwac) consists of dark dusty-red siltstone with ripple marks and mudcracks; light-gray sandstone with cross bedding and Skolithus tubes; and interbeds of dolomitic limestone and dolomite (Southworth and others, 2002).

\section{Elbrook Formation}

The Middle and Upper Cambrian Elbrook Formation (Ce) consists of interbedded, medium-gray and bluish-gray limestone, light- to medium-gray dolostone, and gray shale. The dolostone and shale tend to weather to a yellowish color. The limestone is thin to thick bedded, fine- to mediumgrained, and contains algal bioherms, intraformational conglomerate, and dolomite mottles. The dolostone is medium bedded and fine grained. The thickness of the Elbrook is at least 2,300 ft (Harlow and others, 2005).

\section{Conococheague Limestone}

The Upper Cambrian and Lower Ordovician Conococheague Limestone (OCc) consists of interbedded, mediumgray limestone, light-gray dolostone, and light-gray to buff sandstone. The limestone is thin to medium bedded, fine grained, and contains algal bioherms, intraformational conglomerates, oolites, and interlaminated tan dolostone and gray limestone (ribbon rock). The dolostone is medium bedded and fine grained. The sandstone is present in the lowermost and uppermost parts of the Conococheague and is medium to coarse grained and weathers to a reddish color. The thickness of the Conococheague ranges from 2,200 to 2,600 ft (Harlow and others, 2005).
The Upper Cambrian Big Spring Station Member (Ccbs) forms the basal unit of the Conococheague Limestone and consists of gray to buff, coarse-grained, calcareous sandstone interbedded with intraformational conglomerate and finegrained dolostone. In response to the abundance of sandstone, the Big Spring Station Member tends to form prominent ridges where exposed. The thickness of the Big Spring Station Member is $300 \mathrm{ft}$ (Harlow and others, 2005).

\section{Stonehenge Limestone of the Beekmantown Group}

The Lower Ordovician Stonehenge Limestone (Os) of the Beekmantown Group consists of dark-gray, thick-bedded, fineto medium-grained, fossiliferous limestone. Other characteristic features of the Stonehenge Limestone are algal bioherms, intraformational conglomerates, bioclastic beds, crinkly siliceous laminations, minor black chert nodules, and some minor dolostone beds. The lowermost and uppermost beds of the Stonehenge were formed in a lagoon environment and, therefore, are thin-bedded. The thickness of the Stonehenge is from 600 to $650 \mathrm{ft}$ (Harlow and others, 2005). The basal part of the Stonehenge Limestone consists of a light-gray, silty, laminated limestone (Southworth and others, 2002).

\section{Rockdale Run Formation of the Beekmantown Group}

The Lower and Middle Ordovician Rockdale Run Formation (Orr) of the Beekmantown Group consists of interbedded, bluish-gray, medium-gray, and dark-gray limestone and medium-gray dolostone. The limestone is thin to medium bedded, fine to medium grained, and fossiliferous, and includes intraformational conglomerates, algal bioherms, bioclastic zones, and burrow mottling. The dolostone is medium bedded, fine to medium grained, and crystalline. Nodules and large masses (2 to $4 \mathrm{ft}$ in diameter) of gray chert are common in the Rockdale Run Formation. Topographic knolls with little bedrock exposures tend to form where large masses of Cryptozoon chert are present in the soil of the lower part of the formation. The gastropod Lecanospira is common in limestone beds in the lower and middle part of the Rockdale Run. The thickness of the Rockdale Run Formation is about 1,500 ft (Harlow and others, 2005).

\section{Pinesburg Station Dolomite of the Beekmantown Group}

The Middle Ordovician Pinesburg Station Dolomite (Ops) of the Beekmantown Group consists of medium- to light-gray, buff to light weathering, cherty dolostone and dololaminite. The Pinesburg Station is medium- to thickbedded, fine-grained, and weathered dolostone that typically exhibits a distinctive "butcher-block" (cross-hatched joints) structure. The lower part of the formation is characterized by a few thin limestone beds that are medium gray and fine grained. Near the top of the formation, collapse breccias and irregular bedding are the paleokarst structures that indicate subaerial exposure during Middle Ordovician time. Thickness of the Pinesburg Station Dolomite ranges from 650 to $875 \mathrm{ft}$ (Harlow and others, 2005). 


\section{New Market Limestone}

The Middle Ordovician New Market Limestone, Lincolnshire Limestone, and Edinburg Formations (Oeln) usually are mapped as an undivided unit on small-scale maps because of the thin nature of these Middle Ordovician limestone units. The New Market Limestone consists of dove-gray and medium-gray, micritic, fenestral limestone. The New Market is thick-bedded, high purity limestone that can be as much as 98-percent calcium carbonate (Edmundson, 1945). Many quarries in the Shenandoah Valley have been established to extract the high calcium limestone of the New Market. The thickness of the New Market Formation is from 140 to $200 \mathrm{ft}$ (Harlow and others, 2005).

\section{Lincolnshire Limestone}

The Middle Ordovician Lincolnshire Limestone consists of dark-gray to very dark-gray limestone with bedded, black, chert nodules and medium-gray, bioclastic limestone (fig. 5). The limestone is medium bedded and medium to coarse grained; however, the bioclastic limestone is thin bedded and coarse grained. The thickness of the Lincolnshire Limestone is from 75 to $105 \mathrm{ft}$ (Harlow and others, 2005).

\section{Edinburg Formation}

The Middle Ordovician Edinburg Formation consists of interbedded limestone and medium-dark to very dark-gray, calcareous shale (fig. 5). The limestone is thin to thick bedded, irregularly bedded, fine to medium grained, and exhibits knobby weathering. Yellowish-brown metabentonite is present in thin beds throughout the unit and represents volcanism from an island arc system to the east during the Middle Ordovician. The thickness of the Edinburg is about $500 \mathrm{ft}$ (Harlow and others, 2005).

\section{Chambersburg Limestone}

The Middle Ordovician Chambersburg Limestone (Oc) consists of a dark-gray, fine- to medium-grained, argillaceous (clay-rich) and nodular, fossiliferous limestone (Southworth and others, 2002). The Chambersburg Limestone is only present in a small area of the northwest part of the county along the border with Jefferson County, WV, and is equivalent to the Lincolnshire Limestone and Edinburg Formation to the south (fig. 5).

\section{Metamorphic Rock Unit}

The classification of hydrogeologic units as metamorphic is based on the grouping established in Yager and others (2008). These units represent the oldest rocks in Clarke County and are present along the eastern margin of the Shenandoah Valley on the eastern side of the county in the Blue Ridge. The metamorphic rock unit consists of metabasalt and metasedimentary rocks of the Neoproterozoic Catoctin Formation; phyllite of the Lower Cambrian Loudoun Formation, and the metasedimentary rocks of the Lower Cambrian Weverton, Harpers, and Antietam Formations of the Chilhowee Group (fig. 5).

\section{Catoctin Formation}

The Neoproterozoic Catoctin Formation (Zc) consists of dark green amygdaloidal metabasalt (greenstone) and chlorite schist interlayered with thin, discontinuous, finely laminated phyllitic metasiltstone and thin metasandstone and dark, variegated vesicular tuffaceous phyllite, and mud-lump (ripup) breccias (Reed, 1955). The metabasalt is massive (very thick bedded) to schistose, aphanitic (fine grained) with well developed cleavage and columnar jointing. Near the top and bottom of some metabasalt beds are plagioclase-actinoliteepidote-chlorite-magnetite, quartz-feldpspar-epidote-chlorite amygdules (Hubbard, 1990). The metabasalts are interpreted as basaltic flows and tend to form prominent ledges. Epidosite locally is present as light green, blocky masses in the metabasalt breccia (Southworth and others, 2002). The Catoctin is the oldest unit exposed in Clarke County, and Badger and Sinha (1988) determined a rubidium/strontium (Rb/Sr) age of $570 \pm 36$ millions of years before present (Ma) for the metabasalt of the Catoctin Formation in Virginia. The thickness of the Catoctin Formation is greater than 1,200 ft (Hubbard, 1990).

\section{Loudoun Formation of the Chilhowee Group}

The Lower Cambrian Loudoun Formation (Clp) of the Chilhowee Group consists of a dark variegated phyllite that is amygdaloidal, vesicular, and tuffaceous. Elongated amygdules along the slaty cleavage plane indicate a volcanic origin (Southworth and others, 2002). The Loudoun Formation is only present in the northeast corner of the county along the border with Jefferson County, WV (fig. 5).

\section{Weverton Formation of the Chilhowee Group}

The Lower Cambrian Weverton Formation (Cw) of the Chilhowee Group represents the change from a volcaniclastic to predominantly fluvial environment where alluvial sediments were deposited during the initial stages of a marine transgressive sequence (Schwab, 1986). Whitaker (1955) determined from paleocurrent directions that the source of the sediments was from the west. The Weverton Formation has been divided into three members by Brezinski (1992): the Buzzard Knob, Maryland Heights, and Owens Creek Members (fig. 5). Within each of these members, fining-upward sequences are evident; however, the Owens Creek Member is coarser grained and more poorly sorted than the other members (Southworth and others, 2002). These units have not been mapped separately in the southeastern part of the county, and only the contacts of the undivided Weverton Formation are shown in figure 5 (Virginia Division of Mineral Resources, 2003). The overall thickness of the Weverton Formation ranges from 440 to $600 \mathrm{ft}$ (Hubbard, 1990).

The Buzzard Knob Member (Cwb) consists of light-gray quartzite interbedded with light colored metasiltstone. The quartzite is present as two well-sorted, crossbedded, mature beds that are interbedded with a sandy metasiltstone (Southworth and others, 2002). The Maryland Heights Member (Cwm) consists 
of interbedded, dark-greenish-gray metasiltstone and metagraywacke with dusky-blue to greenish-gray quartzite. The quartzite is very coarse grained with granular beds that vary in thickness from 10 to $30 \mathrm{ft}$. Topographically, swales tend to form on this member between ledges of quartzite beds of the underlying Buzzard Knob Member and overlying Owens Creek Member (Southworth and others, 2002). The Owens Creek Member (Cwo) consists of green to dark-gray sandstone to pebble conglomerate. Nickelsen (1956) noted that "gunmetal blue" is a diagnostic color for this unit. The sandstone is coarse grained, and the conglomerate contains pebbles of blue and red quartz, magnetite, opaque minerals, and blue-green phyllite clasts that can be up to 6 in. long, which give rise to the dark blue color. A clean gray-green conglomeratic quartzite is present at the base of the Owens Creek Member (Southworth and others, 2002).

\section{Harpers Formation of the Chilhowee Group}

The lower part of the Lower Cambrian Harpers Formation (Ch) of the Chilhowee Group consists of greenishbrownish-gray, phyllitic metasiltstone interbedded with meta-arkose and basal pebble conglomerate. The phyllitic units are very fine grained and thick bedded (Hubbard, 1990). Bedding, however, is typically obscured by the strongly developed cleavage (Southworth and others, 2002). The upper part of the Harpers Formation consists of light-gray to brown, thin-bedded, ferruginous, magnetite-rich metasandstone (Chs), which contains trace fossils, Skolithos tubes, and Arenicolites burrows (Hubbard, 1990; Southworth and others, 2002). The thickness of the Harpers Formation ranges from 2,200 to 2,500 ft (Hubbard, 1990).

\section{Antietam Formation of the Chilhowee Group}

The lower part of the Lower Cambrian Antietam Formation (Ca) of the Chilhowee Group consists of very light-gray quartzite interbedded with green-gray, sandy metasiltstone. Skolithos tubes are numerous in the quartzite beds. The Antietam becomes coarser grained higher in the formation ranging from a bioturbated, very light-gray, medium-bedded, wellsorted, fine- to medium-grained sandstone to a medium-gray, calcareous, crossbedded, coarse-grained sandstone (Southworth and others, 2002). The upper contact of the Antietam Formation delineates the boundary between the Blue Ridge to the east and the Valley and Ridge to the west. The thickness of the Antietam ranges from 200 to $800 \mathrm{ft}$ (Hubbard, 1990).

\section{Siliciclastic Rock Unit}

The siliciclastic rock unit is composed of clastic noncarbonate sedimentary rocks that primarily consist of silicabearing minerals such as quartz. In Clarke County, the siliciclastic rock unit is present in the western part of the Great Valley section and is the youngest consolidated rock present in the County. This unit consists of shale, sandstone, and siltstone of the Middle and Upper Ordovician Martinsburg Formation (fig. 5).

\section{Martinsburg Formation}

The Middle and Upper Ordovician Martinsburg Formation $(\mathrm{Om})$ consists of interbedded, medium-gray to dark-gray shale and medium-gray sandstone and siltstone. Weathered shale tends to be olive gray, grayish orange, and yellowish orange; the sandstone and siltstone weather grayish orange. The sandstone and siltstone is medium gray, is very fine grained to fine grained, and fines upward. Graywacke is more abundant and thicker bedded higher in the formation where it forms conspicuous ribs in creek beds. The Martinsburg Formation cores the Massanutten synclinorium along the western part of Clarke County and represents the deepest environment of deposition for the Cambrian and Ordovician rocks of the Shenandoah Valley. The thickness is about 2,600 ft, but Orndorff and others (1999) indicate the Martinsburg may be as much as $5,000 \mathrm{ft}$ thick regionally.

The Middle Ordovician Stickley Run Member (Oms) forms the basal unit of the Martinsburg Formation and may be as thick as $900 \mathrm{ft}$ (Epstein and others, 1995). The Stickley Run Member consists of gray to medium-dark-gray, calcareous shale and medium-gray to grayish-black, olive-gray, grayishorange limestone. The limestone is very thin bedded, platy, very fine grained, laminated, and argillaceous. The Stickley Run Member is mapped as undivided from the Martinsburg in figures 2 and 5.

\section{Structural Geology}

The Great Valley section of Clarke County is located on the eastern limb of the regional Massanutten synclinorium (fig. 2), which is a complexly folded and faulted synclinal trough with numerous tight, upright, second- and third-order, disharmonic folds (anticlines and synclines) that verge up the limbs of the higher order synclinorium. The synclinorium is doubly plunging at low angles; the north end plunges to the south, and the south end plunges to the north. The Massanutten synclinorium contains about a 3-mi-thick section of siliciclastic and carbonate rocks. The axis of the synclinorium in Clarke County is underlain by the Middle and Upper Ordovician Martinsburg Formation. The eastern limb of the synclinorium is characterized by rocks with nearly vertical dips to the northwest or locally overturned beds with steep dips to the southeast (Southworth and others, 2002; Yager and others, 2008). Although Clarke and Frederick Counties are within the same structural block (the Massanutten block), the rocks in Frederick County, which are situated on the western limb of the Massanutten synclinorium, dip gently to the southeast (Harlow and others, 2005; Yager and others, 2008).

The Neoproterozoic and Lower Cambrian rocks of the Blue Ridge have been folded and thrust-faulted over the younger rocks of the Great Valley and form the northwest flank of the Blue Ridge-South Mountain anticlinorium, which plunges gently northeastward (Gathright and Nystrom, 1974). These rocks were part of a 3-mi-thick wedge of rocks that were folded and transported by faulting from the east a 
distance of more than $100 \mathrm{mi}$ during the tectonic activity of the Alleghanian orogeny about 300 million years ago (Southworth and others, 2007). The rocks of the Blue Ridge have undergone lower greenschist-facies metamorphism; however, most of the carbonate rocks of the Great Valley have not been metamorphosed (Southworth and others, 2002).

The structural deformation has created weaknesses in the competent bedrock that are of hydrologic importance because these features enhance weathering and create pathways for groundwater movement. Furthermore, bedding, joints, and foliations in the bedrock are preserved as relicts in the mantle of regolith material, which facilitates movement of water from the surface into the groundwater systems of the county (Harlow and others, 2005).

\section{Bedding-Plane Partings and Joints}

Groundwater flows through, and is stored in, the secondary permeability of bedding-plane partings and joints in the bedrock that result from various processes. Bedding-plane partings (fig. 6) are separations between different layers or beds in sedimentary rocks and between basaltic flows in the metabasalt of the Catoctin Formation. The tectonic forces of the Alleghanian orogeny formed four types of joints (fractures) in the rocks: dip, oblique, strike, and tension (fig. 6).
Extension in the least principal stress direction causes dip joints to form perpendicular to fold axes. Conjugate sets of oblique joints form as the rocks are sheared. Strike joints form parallel to fold axes, and tension joints form along fold hinges (Harlow and others, 2005). Joint types vary with rock type. Brittle deformation is characteristic of the carbonate, sandstone, and metabasalt, and ductile deformation is characteristic of the finer-grained rocks such as the shale of the Martinsburg Formation and phyllite in the Blue Ridge. Axial planar cleavage is most evident in the shale of the Martinsburg Formation (Harlow and others, 2005). Columnar jointing is present in the Catoctin Formation as a result of shrinkage during cooling of the basalt to form hexagonal joints, but is relatively uncommon in Clarke County (Lukert and Nuckols, 1976).

Dips of bedding-plane partings and the various joint types are highly variable and range from horizontal to vertical and can be overturned, but are generally between 10 and $80^{\circ}$ (Wright, 1990); however, steeply dipping beds are prevalent in Clarke County because of location on the highly deformed eastern limb of the Massanutten synclinorium. Dip directions generally are to the northwest or southeast (Southworth and others, 2002; Yager and others, 2008). Although the strike of the rocks in Clarke County is variable, the general strike ranges from $\mathrm{N} .10^{\circ} \mathrm{E}$ to N. $20^{\circ} \mathrm{E}$ (Wright, 1990).

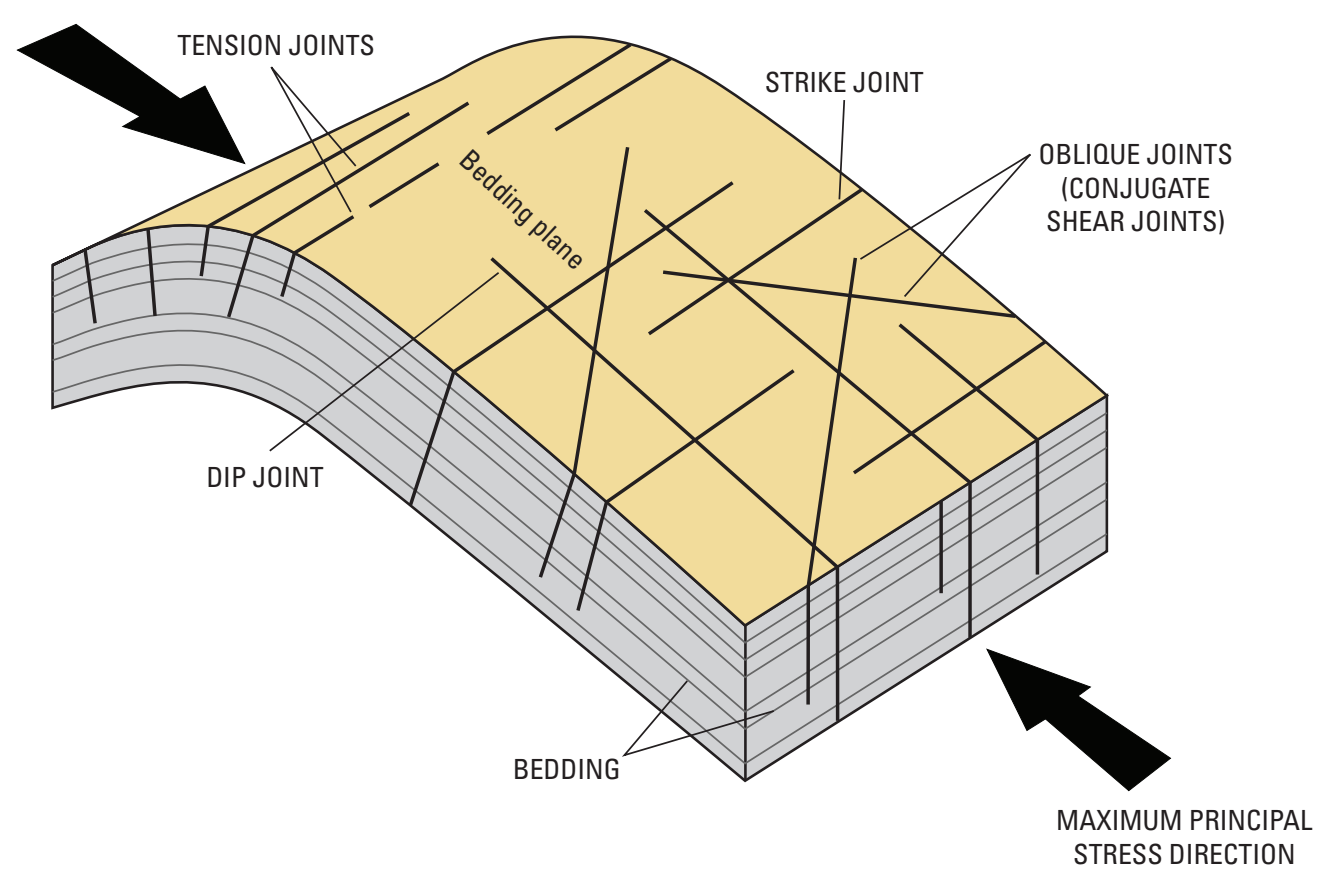

Figure 6. Graphic representation of joint types and bedding in folded rocks (modified from Earth Science Australia, 2004; Harlow and others, 2005). 
Folds

Folds of various types are present in Clarke County and generally have fold axes that trend N. $15^{\circ}$ E to N. $20^{\circ} \mathrm{E}$ (Wright, 1990). Folds plunge to the north-northeast generally at $10^{\circ}$ to $20^{\circ}$, but can range from less than $5^{\circ}$ to at least $35^{\circ}$. Deformation has the character of many subsidiary folds developed on the limbs of the major folds. Generally, the west limbs of folds have very steep dips and can be overturned. Fold amplitude and wavelength range from less than $100 \mathrm{ft}$ to several thousands of feet (Gathright and Nystrom, 1974). An apparent disharmony in fold wavelength in response to rheological differences of the rock units was noted by Orndorff and others (1999). Folds in the Martinsburg Formation have shorter wavelengths than the folds in the Cambrian and Lower Ordovician carbonate rocks with intermediate wavelengths in Middle Ordovician limestone. The sinuous appearance of the contacts of some of the hydrogeologic units in figure 5 is indicative of folded rocks. As an example, an anticline with a fold wavelength of approximately $1,000 \mathrm{ft}$ is clearly visible in the streambed just south of Calmes Neck (fig. 7) during low-flow conditions of the Shenandoah River at the time of acquisition of the aerial photography in 2002.

\section{Faults}

Several fault types have been mapped in Clarke County (fig. 5). Thrust faults strike north-northeast and dip southeast, whereas local back thrusts dip steeply to the northwest (Gathright and Nystrom, 1974; Yager and other, 2008). Most of these faults parallel the strike and generally trend N. $15^{\circ} \mathrm{E}$ (Edmundson and Nunan, 1973; Wright, 1990). Some of the faults along the boundary between the Great Valley section and Blue Ridge have been folded as evidenced by the sinuous trace of the Keedysville detachment fault in figure 5 (Southworth and others, 2007). Several high-angle transverse and normal faults cut across the boundary between the two geologic provinces in the county. Numerous local transverse or cross-strike faults are present in the Valley and Ridge and Blue Ridge.

Lineaments (fig. 8) are linear surface features that can reflect areas of concentrated fractures or faults. Lineaments were mapped in Clarke County by Hubbard (1990). Most of the Landsat lineament zones are nearly normal to the strike of the rocks, fault traces, and fold axes. Parts of the lineament zone that extends from Ashby Gap through Millwood, however, coincides with a near-vertical normal fault downthrown on the southwest mapped in the Blue Ridge along Route 50 (Gathright and Nystrom, 1974). Most of the lineament zones converge in the northwest part of the county. Lineament zones shown in figure 8 likely continue into and possibly through the neighboring counties.

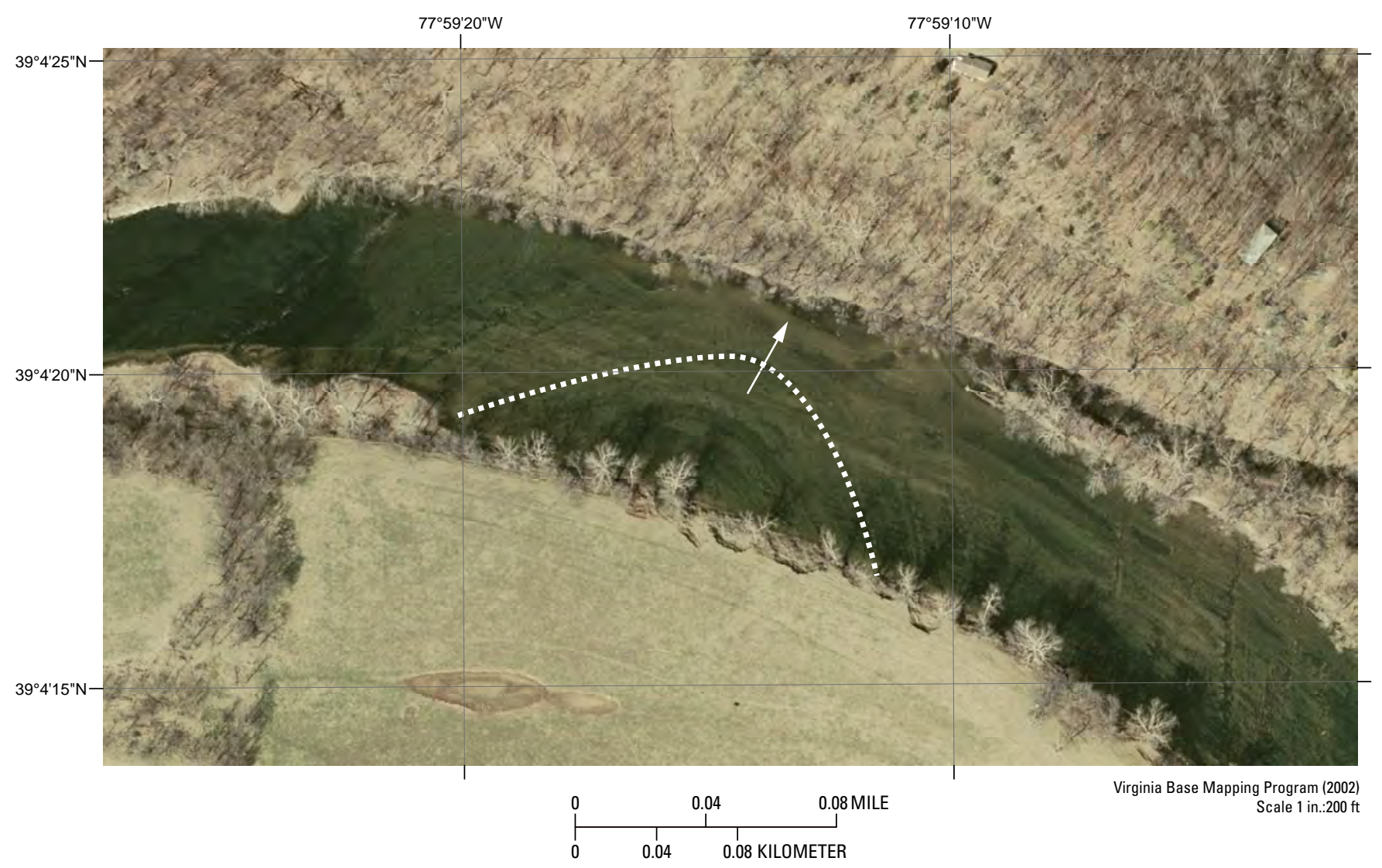

Figure 7. Large plunging fold in the Shenandoah River south of Calmes Neck in Clarke County, Virginia. Dashed line indicates bedding and arrow indicates direction of plunge. 


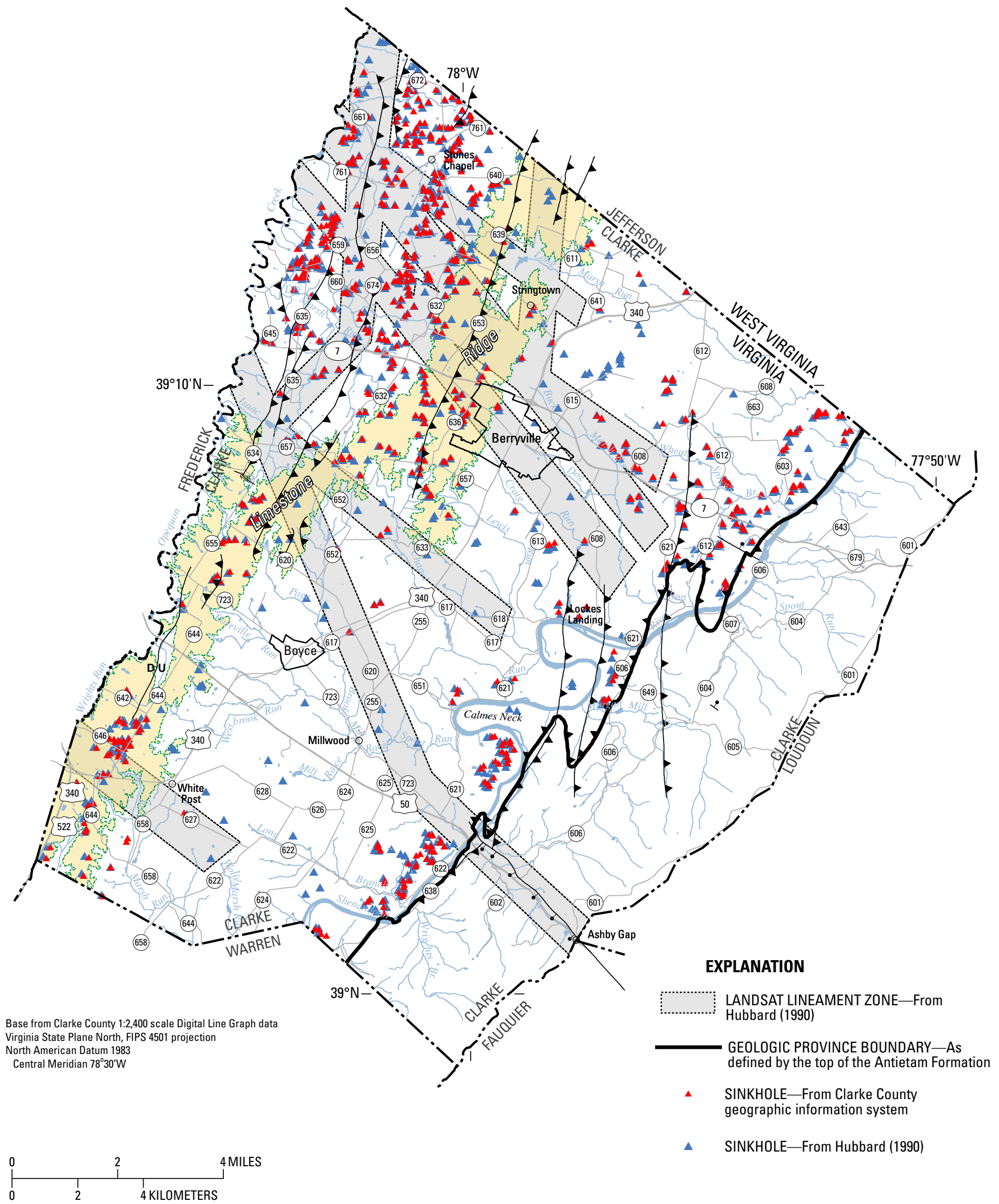

Figure 8. Location of Landsat lineament zones and sinkholes in Clarke County, Virginia. 


\section{Karst Features}

Sinkholes, solution-enlarged conduits, caves and caverns, estavelles, and sinking and dry streams are characteristic features of karst terrain. Acidic precipitation infiltrates the subsurface and dissolves the very soluble carbonate rocks to form these features. Lithologic characteristics, fracture density, proximity of carbonate rock to streams, land slope, and geologic structure are controlling factors in sinkhole development (Orndorff and Goggin, 1994; Hyland and others, 2006). Sinkholes are more abundant and increase in size near incised streams like Opequon Creek and the Shenandoah River. The greater development of sinkholes near streams has been attributed to the steepened hydraulic gradient and increased rate of groundwater flow in these areas (Hubbard, 1983). The relation between sinkhole development and folds, especially noses of anticlines and synclines, is well established (Hack, 1965; Hubbard, 1983, 1990; Orndorff and Goggin, 1994; Doctor and others, 2008). Doctor and others (2008) also noted that sinkholes usually form in elevated and flat (less than 5 degree slope) areas. Hubbard (1990) and Wright (1990) documented sinkhole development during well construction and pumping. The greatest density of sinkholes is in the northwest part of the county (fig. 8).

\section{Hydrology}

Groundwater flows through bedrock- and regolith-aquifer systems in Clarke County. The bedrock systems are characterized by karst and fractured-rock aquifers that have developed in the folded and faulted rocks. Conduit- and diffuse-flow conditions are present in the karst aquifer systems in areas underlain by the carbonate rock unit. Diffuse-flow conditions are characteristic of the fractured-rock aquifer systems in areas underlain by the siliciclastic and metamorphic rocks (Jones, 1987; Hubbard, 1990; Wright, 1990). Diffuse, porous-media flow is present in the regolith material overlying bedrock. Preferential groundwater flow also is present along relict structures in the regolith. The karst and fractured-rock aquifers generally are unconfined, and groundwater gradients are controlled by topography. Confined aquifers, however, may be present locally (Harlow and others, 2005). Groundwater recharge is derived from precipitation. Recharge occurs by percolation of water through the regolith mantle to the bedrock, along partings in the rock, and by direct inflow into sinkholes and from sinking streams. Groundwater eventually discharges to streams primarily in the form of spring discharge.

\section{Hydrogeologic Characteristics}

Each of the hydrogeologic units has distinctive characteristics that are evident in the records provided by local well drillers. More than 1,800 well records from files maintained by the Virginia Department of Environmental Quality (VDEQ), the Virginia Department of Health, Clarke County, and the USGS were analyzed to determine well-construction characteristics, well yield, and water-bearing characteristics of the different hydrogeologic units. The results of this analysis are presented in tabular form (table 1) and graphical form as boxplots (fig. 9), and they are described in detail below. The blue-shaded areas in figure 9 represent the 95-percent confidence intervals. In most cases, the confidence intervals for the hydrogeologic units overlap, which indicates the characteristics of these hydrogeologic units are not significantly different statistically. This is not unusual because nearly all of the wells in the analysis were drilled for domestic use (Cederstrom, 1972). Maps shown in the following sections were derived from well-construction data by using an inverse, distanceweighted method in ArcGIS $^{\circledR}$ ArcMap $^{\circledR}$ version 9.3 that used a power of 2 and a variable search radius of 12 points around each point to create a contour grid of the respective hydrogeologic characteristic.

During this investigation, a long-term, water-monitoring network was established for Clarke County. Water levels were measured quarterly in more than 40 wells, as well as discharges and field water-quality properties at 23 springs across the county, between October 2002 and October 2008. Site information for the wells and springs can be found in appendixes 1 and 2, respectively. Individual water-level measurements are listed in appendix 3, and discharge and water-quality measurements are in appendix 4. Seasonal and spatial changes in water levels and discharges are described below.

\section{Well Depths}

Well depths in Clarke County range from 23 to 1,020 feet below land surface (ft bls; table 1 and fig. 9). The shallowest wells are numerous large-diameter, hand-dug, stonelined wells located in the Great Valley section of the county. Some of these wells have been reported to date back to the 1700 s. These wells were commonly dug either adjacent to, or upgradient from, intermittent springs. Generally, median well depths are deep in the metamorphic rocks of the Blue Ridge, which is a reflection of the elevated setting, depth to water-bearing zones, and relatively low hydraulic conductivity of these hydrogeologic units. The occurrence of dissolutionenlarged openings and relatively low relief of the carbonate rock types contributes to the shallower median well depths than those in the Blue Ridge. The deepest well inventoried during this study, however, was drilled to $1,020 \mathrm{ft}$ into the Beekmantown Formation.

\section{Well Yields}

Well yields in Clarke County range from 0.4 to 600 gallons per minute (gal/min; table 1 and fig. 9). Dry holes are not uncommon, and filing of well-completion reports is not required. Most of the well-yield data are from short duration, 
airlift tests conducted after total depth of the wells had been reached. Less than 10 of the wells had sufficient data to calculate specific capacity, which is pumped discharge divided by the amount of water-level drawdown. Tukey's multiplecomparison test, a rank transform, nonparametric analysis of variance test, was used to compare well yields from the individual hydrogeologic units. At the $p$-value $<0.05$ significance level, the results from the Tukey's analysis indicate that the hydrogeologic units can be categorized into three groups. The Antietam, Catoctin, and Harpers Formations in the Blue Ridge and the Stonehenge Limestone of the Beekmantown Group are categorized as having low well yields. The undivided Beekmantown Group and Conococheague Limestone, Elbrook Formation, and New Market Limestone have moderate well yields. The Tomstown Dolomite and Waynesboro and Weverton Formations could not be statistically differentiated from the low and moderate groups; therefore, they are categorized as having low to moderate well yields. Wells finished in the Martinsburg Formation were categorized as having the highest yields. The latter contradicts previous conclusions that the Martinsburg is a low yielding unit (Cady, 1936, 1938; Trainer and Watkins, 1975; Hinkle and Sterrett, 1976, 1977, 1978; Wright, 1990; Yager and others, 2008), but is consistent with findings of Shultz and others (1995) in Berkeley County, WV. A review of the 27 wells finished in the Martinsburg Formation indicates that 40 percent of these wells are located within Landsat lineament zones, near or along mapped faults, within isolated fault slices, or near the eastern contact of the Martinsburg with the older carbonate units. The small overall sample size coupled with a large percentage of these wells being located in areas conducive to high yielding wells and the possibility that some of these wells may actually obtain water from the Stickley Run Member of the Martinsburg Formation, which is a carbonate rock, create a potential bias in the statistical analysis that may not be representative of the siliciclastic rocks of the Martinsburg Formation. A high-yielding well (130 gal/min) was recently drilled in Warren County that produced from the Stickley Run Member, which was overlain by $225 \mathrm{ft}$ of shale (D.L. Nelms, U.S. Geological Survey, written commun., 2009).

A spatial analysis was conducted to identify areas where well yields tend to cluster as either low (less than $5 \mathrm{gal} / \mathrm{min}$ ) or high (greater than $50 \mathrm{gal} / \mathrm{min}$ ). In the Great Valley section, many of the areas with the highest density of low-yielding wells are present where lineament zones or faults have not been mapped (fig. 10). To some degree, the same is true for the Blue Ridge; however, several high density areas of lowyielding wells are present in areas underlain by tight folds and faults. High-yielding wells generally tend to cluster along faults, within lineament zones, and in areas of tight folding throughout the county (fig. 11). A comparison of density clusters indicates that some areas contain a dense concentration of both low- and high-yielding wells. This is one example of the degree of complexity inherent with karst and fractured-rock aquifer systems. For example, the clusters of both low- and high-yielding wells along Route 7 about $1.5 \mathrm{mi}$ east of the boundary between the provinces are located in an intensely folded and faulted area. Many of the high-yielding wells are less than $200 \mathrm{ft}$ deep, whereas the low-yielding wells generally are greater than $300 \mathrm{ft}$ deep.

The statistical and spatial analyses described previously should be considered a general indication of well-yield characteristics rather than a rigorous evaluation of the yielding capacity of the hydrogeologic units in the county. As stated earlier, wells in the dataset were drilled for domestic purposes and have been sited in accordance with local ordinances and not to maximize well yield. In addition, most of the drilled wells are 6 in. in diameter, which can limit well yield. Also, 75 percent of the wells have depths less than $400 \mathrm{ft}$. Cady (1936) observed that the average yield of wells drilled deeper than $300 \mathrm{ft}$ in the carbonate rocks is three times as great as those drilled shallower than $300 \mathrm{ft}$. The relation between well yield and depth has not been thoroughly investigated for the metamorphic rocks. Other investigations have indicated that yields increase with depth (Cressler and others, 1983; Daniel, 1989; Swain, 1993; Hansen and Simcox, 1994; Loiselle and Evans, 1995).

\section{Depth to Bedrock}

Median depths to bedrock are less than $50 \mathrm{ft}$ bls in Clarke County (table 1 and fig. 9). The metamorphic rocks of the Harpers Formation and the carbonate rocks of the Waynesboro Formation and Tomstown Dolomite in the eastern part of the county have a larger range of depths to bedrock than the other hydrogeologic units in the county (fig. 12). Numerous outcrops of carbonate rocks in the western part of the county provide evidence of shallow depths to bedrock in that area. Hack (1965), Edmundson and Nunan (1973), Gathright and Nystrom (1974), and Hubbard (1990) mapped a thick residual mantle on carbonate rocks in the eastern part of Clarke County. The deep depths to bedrock for the Waynesboro Formation are present at the base of the Blue Ridge Mountains in areas adjacent to the Shenandoah River (especially near the Route 50 bridge; fig. 1), where thick residual mantle and terrace deposits (Hubbard, 1990) are mapped. Although few of the wells inventoried in the Martinsburg Formation had depth to bedrock reported, Hack (1965) states that this formation generally lacks residuum.

Much of Clarke County has some mantle over the bedrock, but groundwater storage in this mantle is believed to be minimal (Harlow and others, 2005). The areas with a thick sequence of regolith overlying the Waynesboro Formation, however, may have considerable storage potential. Areas underlain by the Waynesboro Formation, unlike the Tomstown Dolomite, have slopes that are generally less than 5 degrees, which may reduce surface runoff and consequently facilitate downward percolation of water. 
Table 1. Well-construction characteristics for the hydrogeologic units in Clarke County, Virginia.

[Fm, Formation; Lst, Limestone; Carb., carbonate; Meta., metamorphic; Sili., siliciclastic; n, number of sites; nd, not determined]

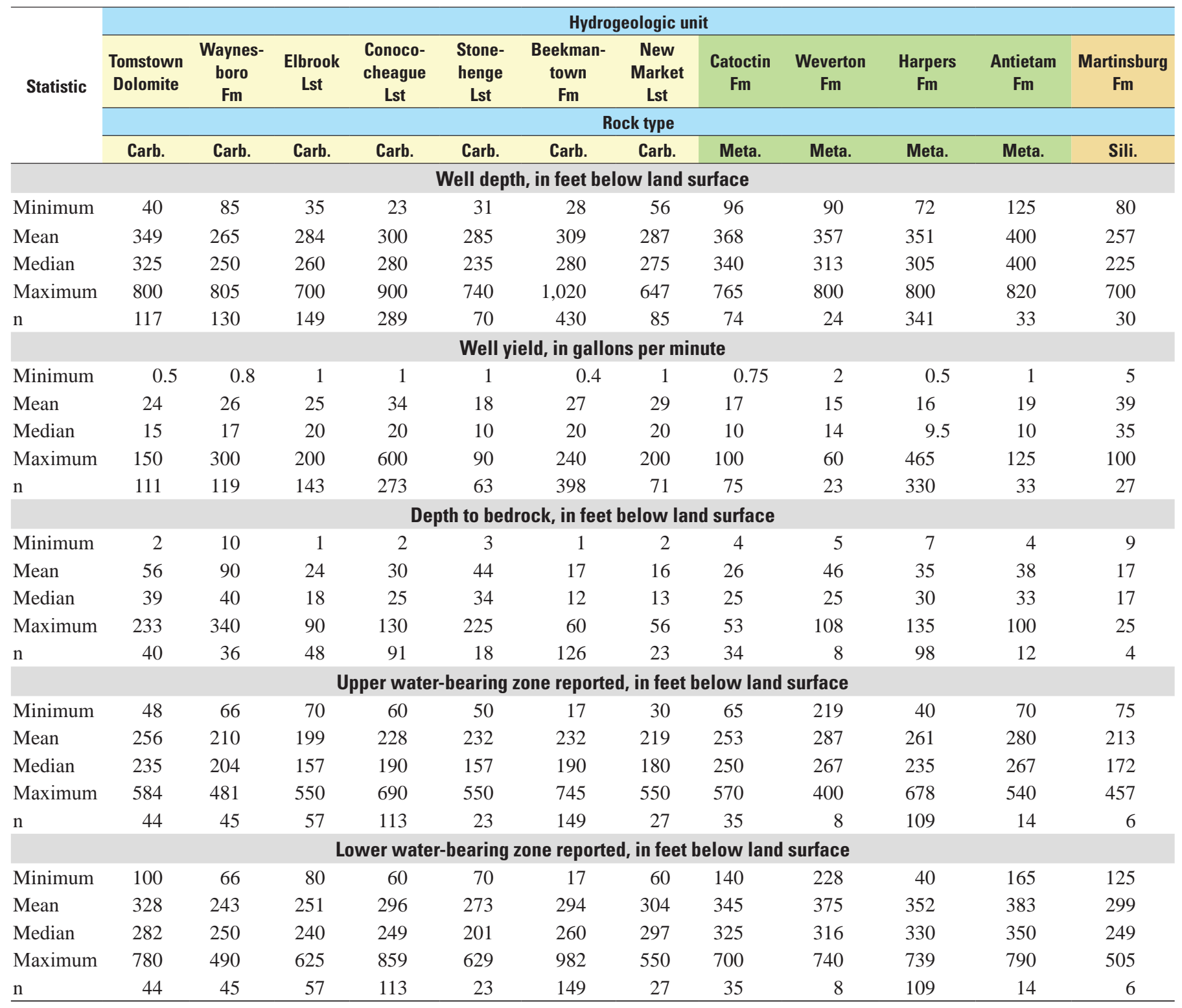



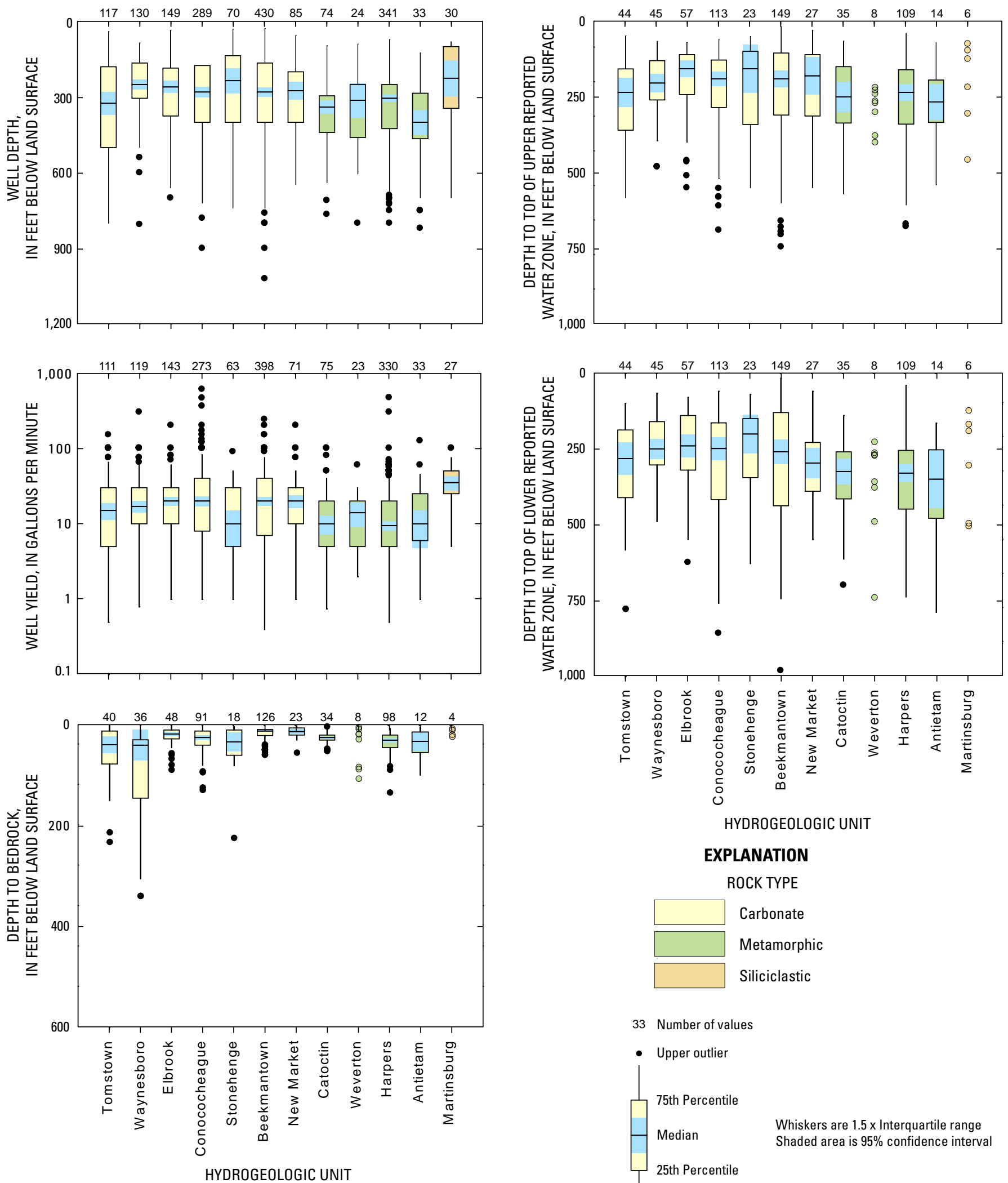

\section{EXPLANATION}

ROCK TYPE
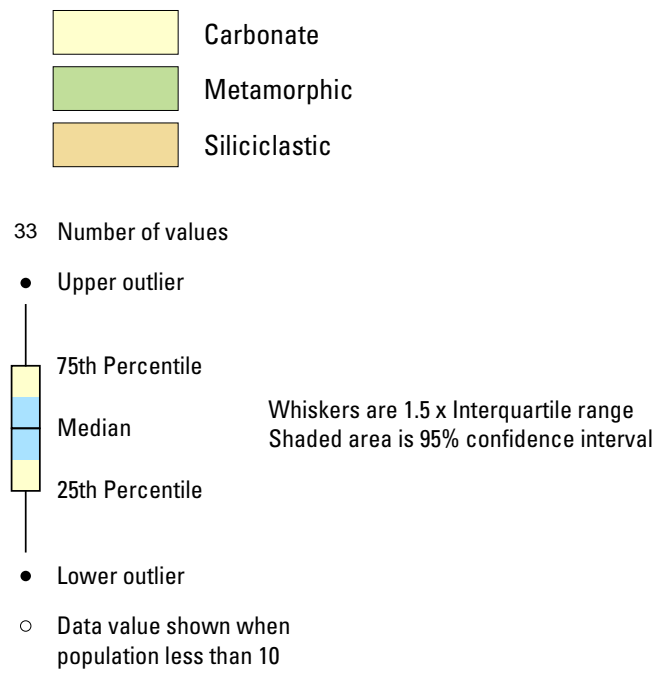

Figure 9. Summary statistics of well-construction and hydrologic characteristics of the hydrogeologic units in Clarke County, Virginia. 


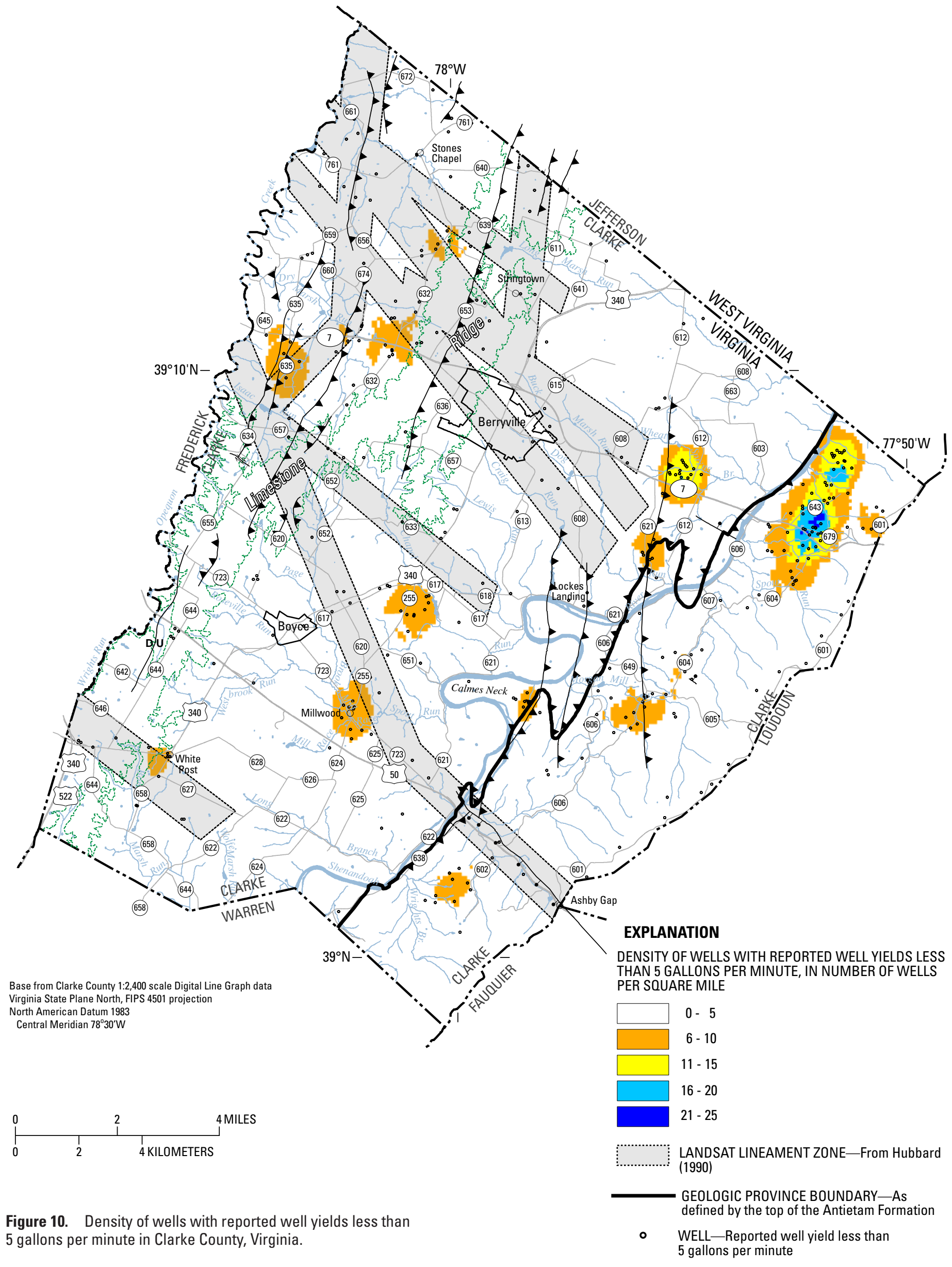




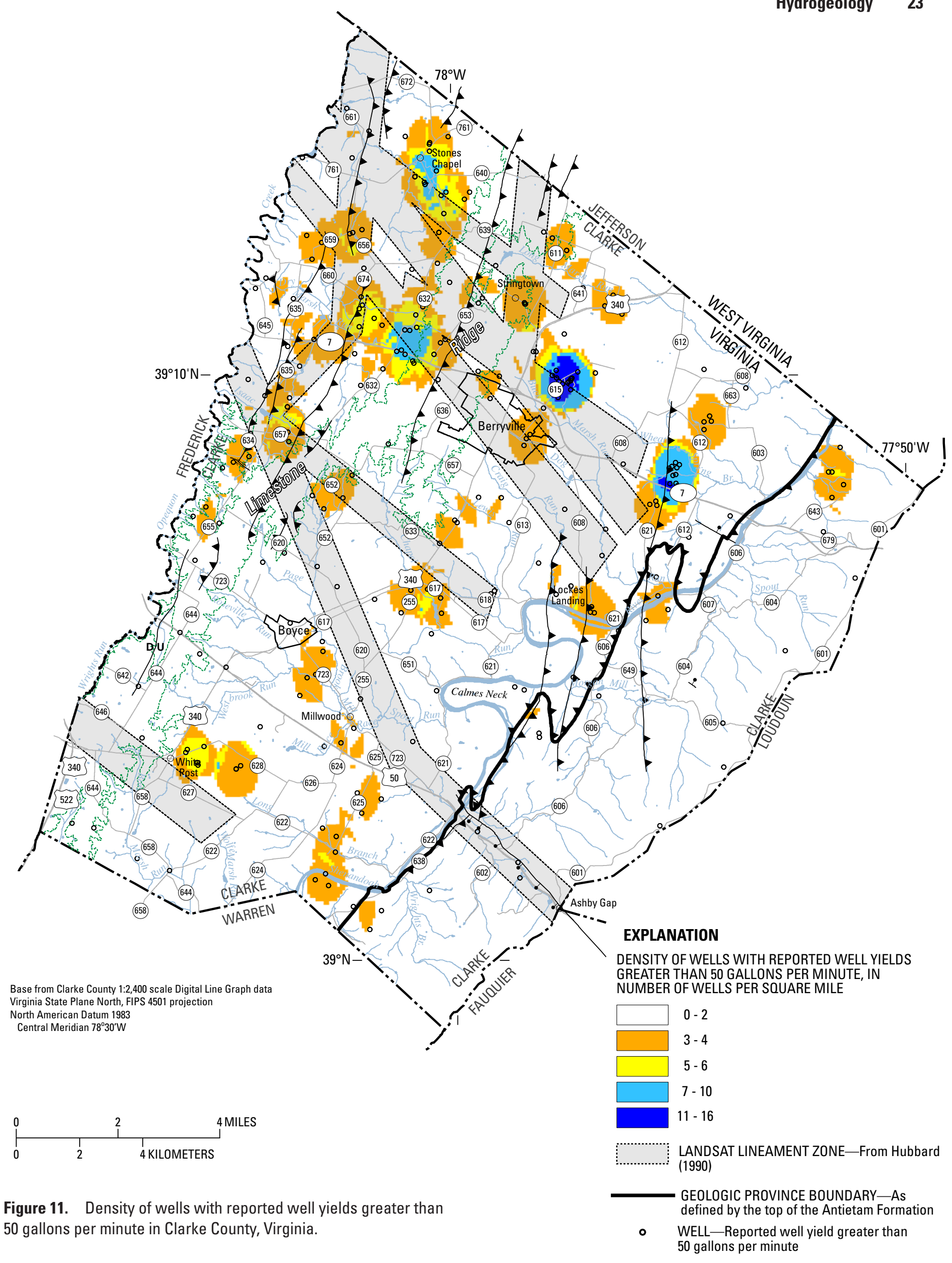




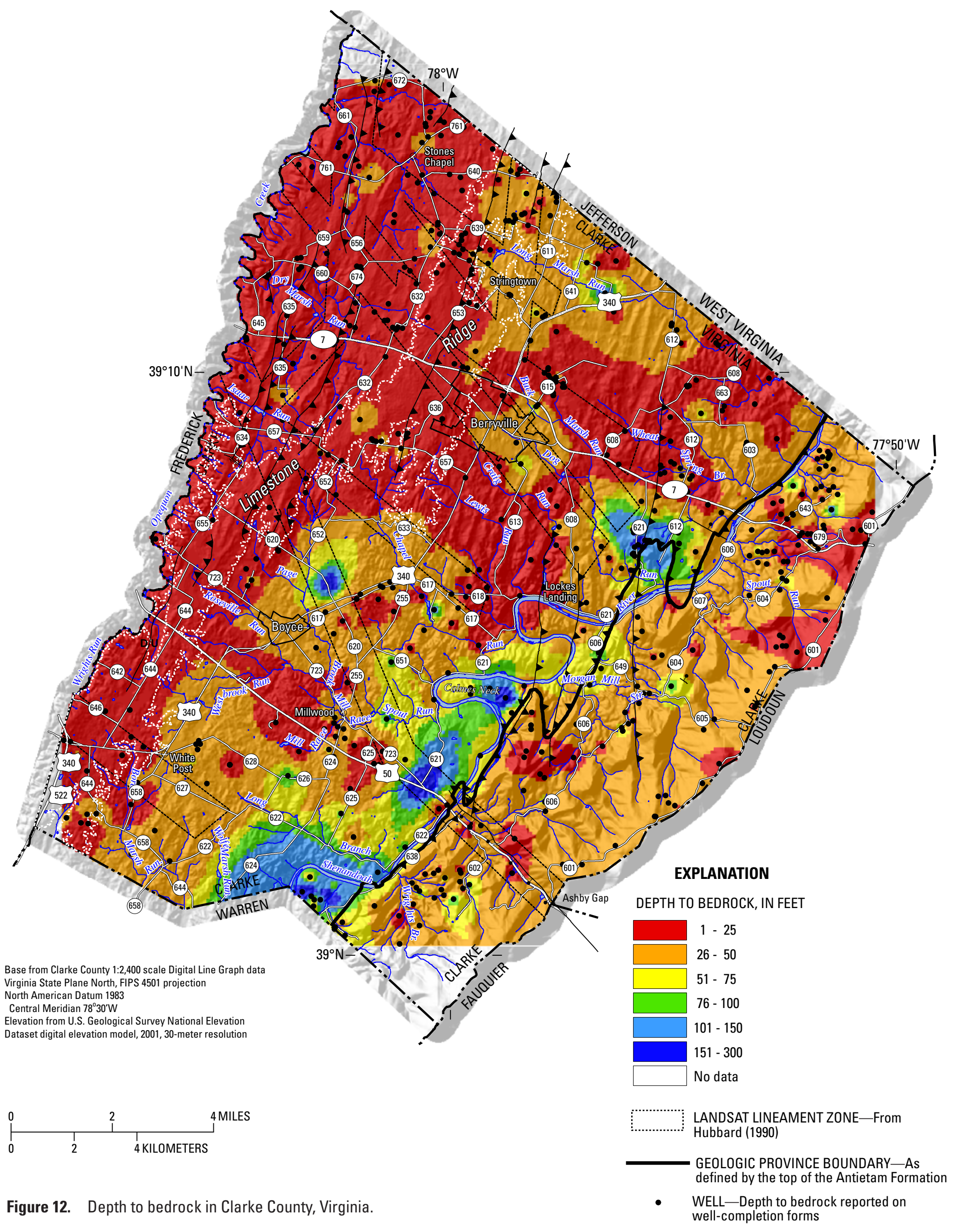




\section{Water-Bearing Zones}

The depth to water-bearing zones identified on wellcompletion reports provides insight into where groundwater is present (table 1 and fig. 9). A well can encounter single or multiple water-bearing zones. Often, zones bearing small amounts of water are encountered but are not reported, and only the major water-bearing zones are recorded. Median depths of the upper water-bearing zones reported indicate that water generally is first encountered in about the upper $250 \mathrm{ft}$ below land surface. However, median depths are slightly deeper for the hydrogeologic units of the Blue Ridge. A similar distribution of depth to the top of the lower water-bearing zones reported also is evident (table 1 and fig. 9).

Spatial distribution of the depths to the top of the upper water-bearing zones in Clarke County provides insight into the topographic and geologic controls on the occurrence of groundwater (fig. 13). In general, several spatial characteristics are evident.

Shallow depths (less than $250 \mathrm{ft}$ bls) are present

- beneath basin boundaries or divides in the upper reaches of basins, especially where divides converge;

- in the Westbrook Run Basin southwest of Boyce;

- along the Shenandoah River where the geologic structure is tight folds and faults, and a thick mantle of residuum and terrace deposits is present (figs. 5 and 12);

- in areas of converging Landsat lineament zones;

- along the Landsat lineament zone in the southern part of the Blue Ridge along Route 50; and

- in elevated parts of faults and lineaments.

Deep depths (greater than 250 feet bls) are present

- along faults and noses of plunging folds, especially tight folds (fig. 5);

- along Landsat lineament zones;

- in the Blue Ridge and the Limestone Ridge area of the Great Valley (fig. 1); and

- in the northern part of the county along the Shenandoah River and the lower reaches of the Opequon Creek Basin.

A similar spatial pattern exists for the depth to the top of the lower water-bearing zones (fig. 14), but the majority of the depths reported are greater than $250 \mathrm{ft}$ bls. About 43 percent of these lower water-bearing zones are between 400 and 1,000 ft bls and are present throughout the county. Cady (1936) and Hack (1965) suggest that water-bearing zones in carbonate rocks may be present at depths as great as 2,000 ft. A recently drilled well in Frederick County yielded more than $100 \mathrm{gal} / \mathrm{min}$ from a single water zone at 1,339 ft, possibly associated with the Apple Pie Ridge fault (G.E. Harlow, Jr., U.S. Geological Survey, written commun., 2005). In fact,
Wright (1990) reported that a well located on a ridgetop in the Blue Ridge section of the county encountered freshwater at about 5,000 ft bls. All of these examples indicate the possibility of encountering water-bearing zones at substantial depths.

The spatial distribution of the depth of water-bearing zones is consistent with the conceptual idea that the groundwater flow systems are topographically driven and controlled by geologic structure. The shallow water-bearing zones beneath the basin divides are consistent with the idea that recharge occurs in or near these areas. In lower topographic areas, water-bearing zones are deeper because groundwater flows from the elevated areas along geologic structures, which commonly have steep dips. The deep water-bearing zones along faults and lineament zones are the result of high permeability that extends to depth along these features. It should be noted that many of the wells in the dataset were drilled during the drought between 1999 and 2002, and data shown in figures 13 and 14 could be biased towards deeper depths than would be encountered during average or wet conditions. This is especially true in the northwest part of the county, where a majority of the dry wells are located. This potential bias, however, is believed to be slight because a sufficient number of wells drilled during other years are interspersed with those from the drought period. Future well construction may take into account that wells with water zones shallower than those shown in figure 14 may be at risk of going dry or having reduced yield during drought conditions.

\section{Water Levels}

Fluctuations in water levels are the result of natural and anthropogenic effects. The primary natural effects are precipitation, groundwater evapotranspiration, and discharge from the aquifer system to springs and streams (Harlow and others, 2005). Pumpage withdrawals for water-supply demands and surface and subsurface injection are the primary anthropogenic activities that cause water-level fluctuations. In general, recharge of precipitation to the aquifer system causes water levels to rise, and over time these levels slowly decline as water discharges to springs and streams in the area. Harlow and others (2005) state that the amount of seasonal water-level fluctuation varies and is controlled by (1) contributing area of recharge, (2) topographic relief, (3) position in the flow system, (4) amount of evapotranspiration (ET), (5) aquifer permeability, and (6) groundwater discharge to springs and streams. Seasonal water-level fluctuations tend to be greater in the elevated recharge areas and in areas underlain by low permeability rocks; water levels in discharge areas near streams and springs and areas underlain by permeable rocks tend to fluctuate less.

A long-term water-level network was established during this investigation to quantify seasonal water-level fluctuations in Clarke County. Pressure transducers were installed in wells 46W179 and 48X 20 to monitor water levels continuously (fig. 15). Well 46W179 is a 36 -ft deep, stone-lined, hand-dug well located in White Post, approximately $600 \mathrm{ft}$ from the 


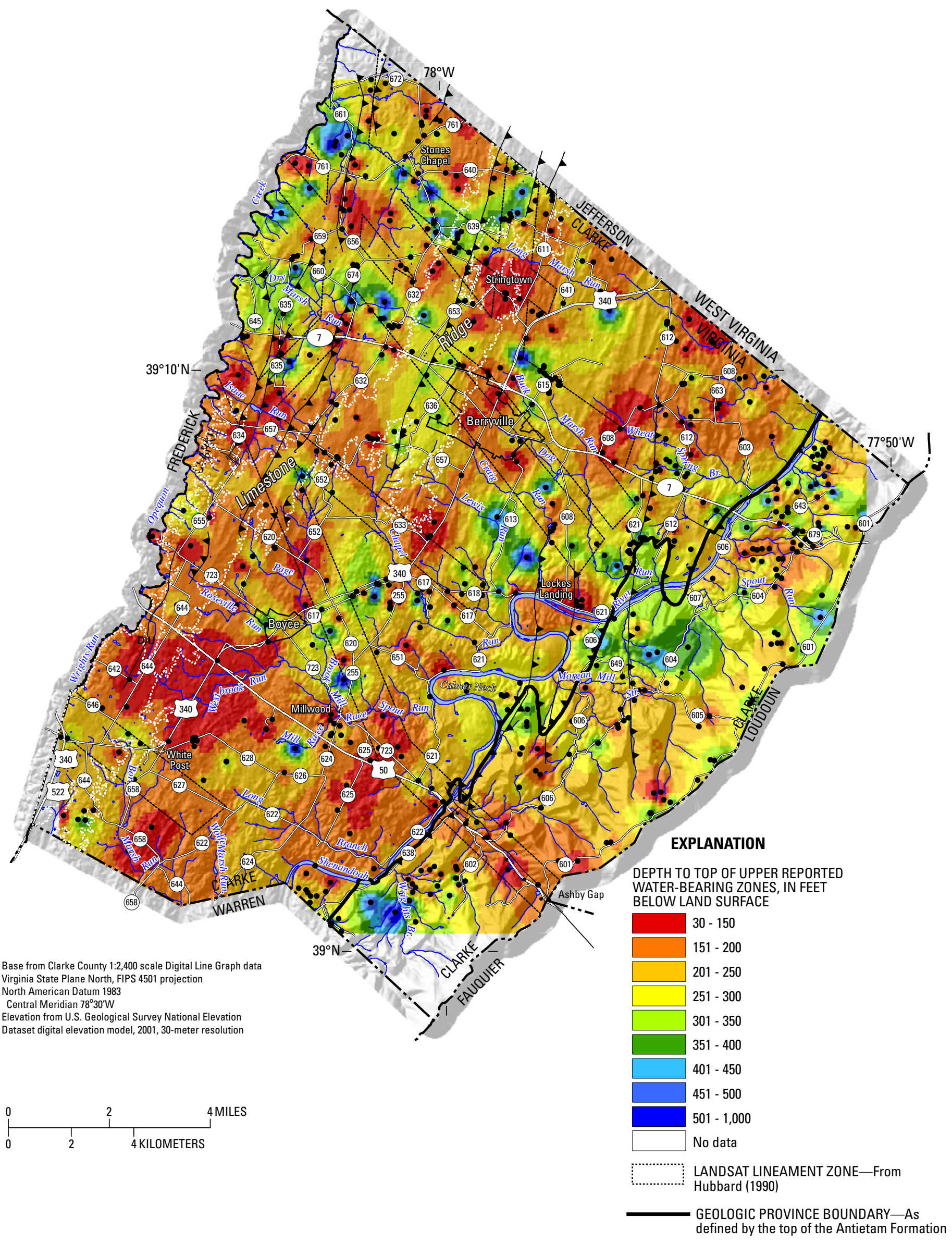

Figure 13. Depth to top of upper reported water-bearing zones in Clarke County, Virginia.

- WELL-Depth to water-bearing zones reported on well-completion forms 


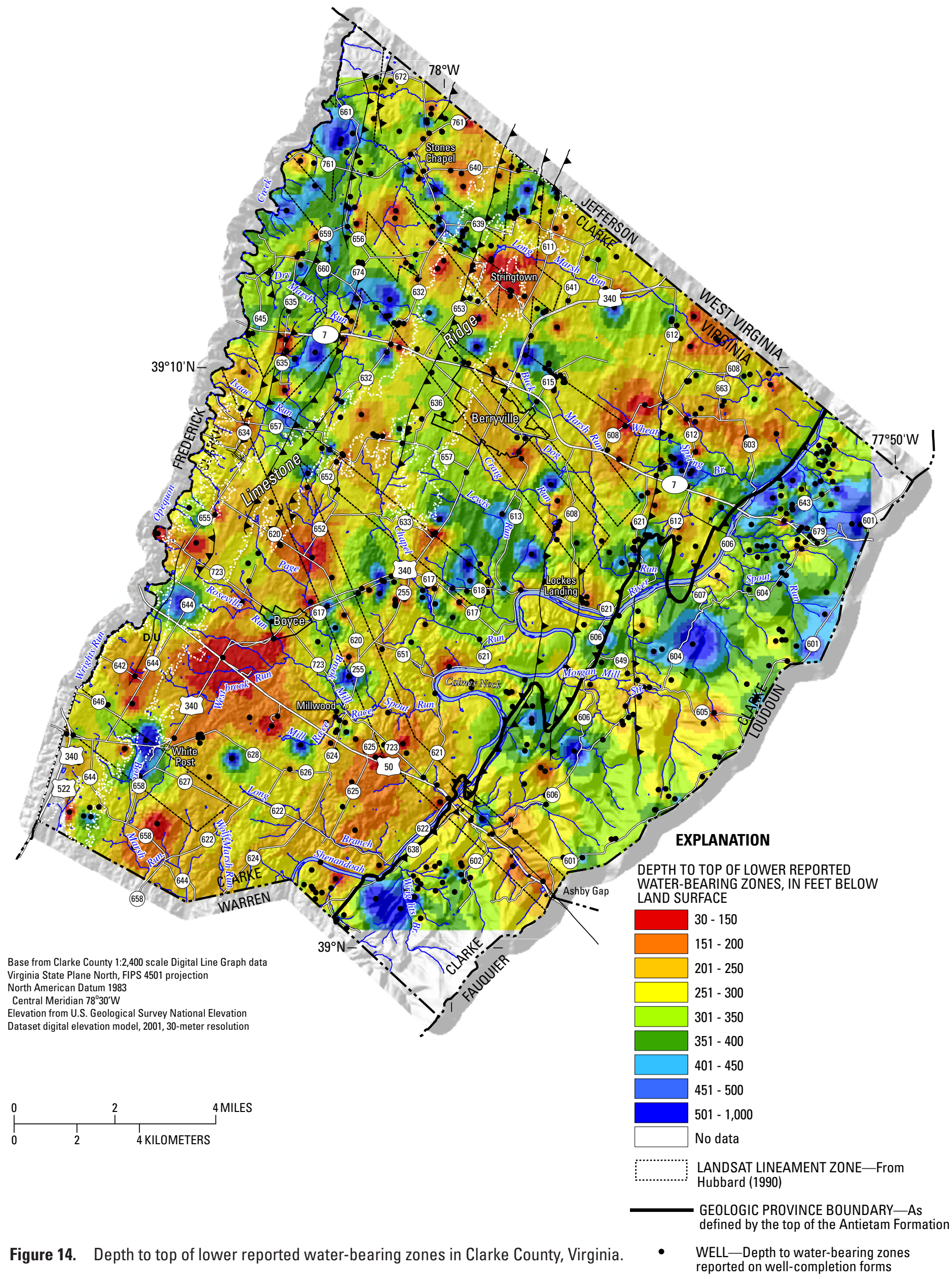




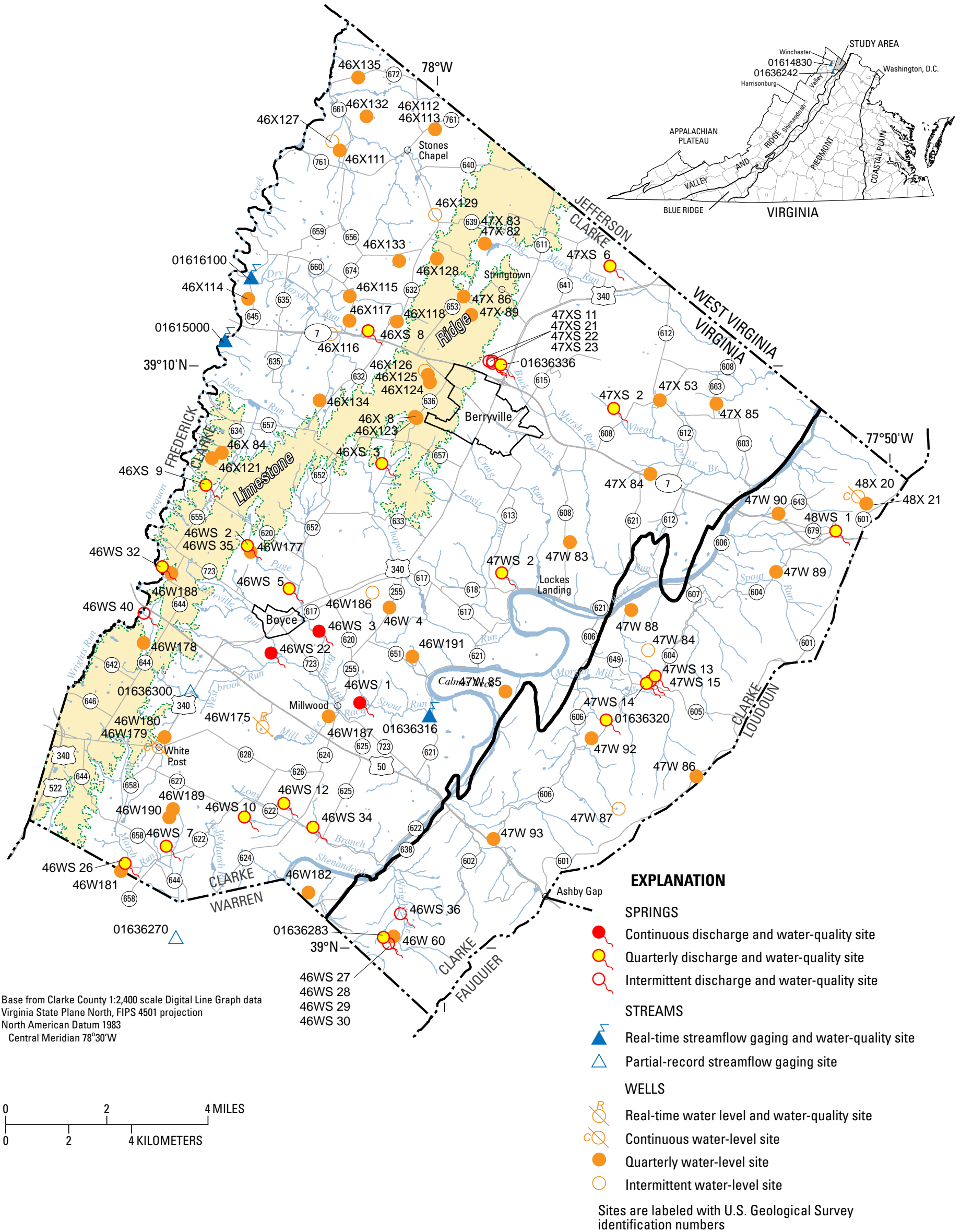

Figure 15. Location of streamflow gaging stations, springs, and wells in the long-term water monitoring network for Clarke County, Virginia. 
divide between Borden Marsh Run and Spout Run Basins. This well is probably open to the residuum of the Rockdale Run Formation. Well 48X 20 is a 63-ft deep, drilled well with $16 \mathrm{ft}$ of 6-in.-diameter steel casing located on a ridgetop in the northeast corner of the county in the Blue Ridge and is open to the Buzzard Knob Member of the Weverton Formation very near the contact with the Catoctin Formation. Well 46W175 located at the University of Virginia's Blandy Experimental Farm and The State Arboretum of Virginia (fig. 15) is part of the statewide observation well network maintained by the USGS and VDEQ. The depth of well $46 \mathrm{~W} 175 \mathrm{is} 80 \mathrm{ft}$, and the well has $24 \mathrm{ft}$ of 6-in.-diameter steel casing. Caliper logging by Wright (1990) indicates a fracture zone between 66 and $68 \mathrm{ft}$ in the Conococheague Formation. Water levels have been measured continuously since July 1987 in well 46W175, which is located in the Spout Run Basin nearly equidistant from the fold axes of the Milldale syncline and Pyletown anticline of Edmundson and Nunan (1973).

Hydrographs of daily maximum water levels recorded in wells 46W175 and 46W179 (fig. 16) indicate that both of these wells are responsive to current climatic conditions. Generally, intense thunderstorms, tropical storms, or hurricanes cause sudden but temporary water-level rises during the summer and autumn. The response in well 46W179 tends to be larger than that in well 46W175 because of shallower depth, lack of available storage, and downward vertical hydraulic gradients that are probably greater than those at well 46W175. The hydrograph for well 46W175 is more subdued, and recessions are of longer duration than those in well 46W179. The two hydrographs suggest that water-level fluctuations are more dampened in the bedrock when compared to those in the regolith. The overall trend in water levels for both wells is downward between 2003 and 2008, which closely follows a downward trend in annual precipitation over the same period (fig. 16). This trend is consistent with the conceptual idea that these aquifer systems undergo a major period of recharge that is followed by a slow decline in water levels as water discharges to springs and streams. Superimposed on this overall cycle are seasonal water-level fluctuations where seasonal highs occur between April and May and lows occur in September and October.
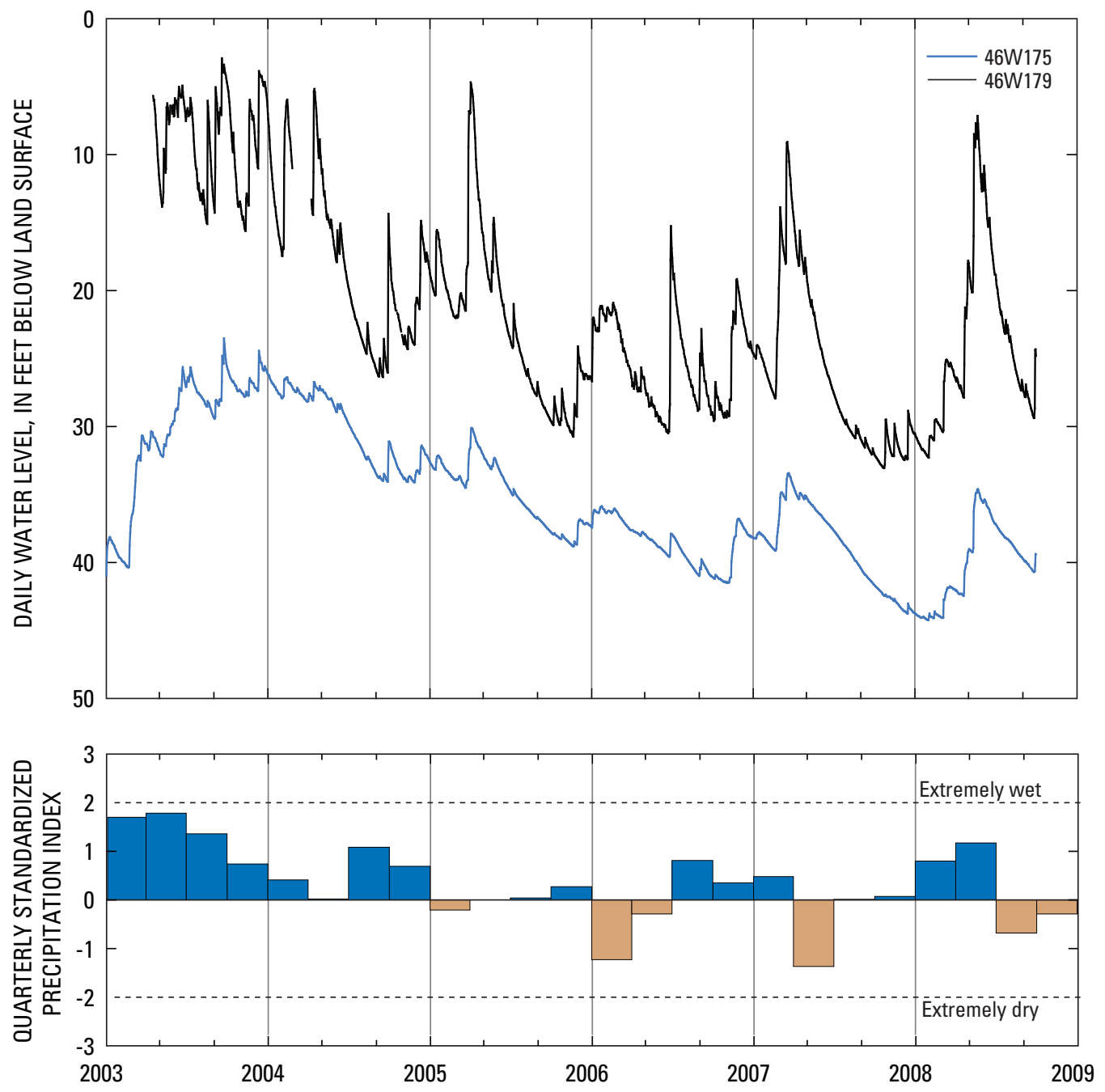

Figure 16. Relation between daily water levels in wells 46W175 and 46W179 and quarterly standardized precipitation index at National Weather Service climatological station 449186 Winchester 7 SE, Virginia. 
The hydrograph for well 48X 20 is typical for a ridgetop setting where the recharge area is limited (fig. 17). Water-level rises in response to precipitation events are frequent, yet the recessions are less steep than those observed in well 46W179 and a seasonal trend is more apparent in well 48X 20. The permeability and storage capacity of the rocks at wells 46W179 and 48X 20 control the differing manners in which these systems drain. Permeability of the Buzzards Knob Member at well 48X 20 is lower than the permeability of the Rockdale Run Formation at well 46W179; therefore, water-level recessions should be less steep and have a longer period. The downward trend in water levels from 2003 to 2008 identified in the Great Valley wells is not evident in the water levels recorded in the Blue Ridge at well 48X 20. Water-level fluctuations in well 48X 20 tend to follow current climatic conditions, and seasonal highs and lows tend to shift in response to the current conditions. For example, precipitation throughout 2007 was nearly 7 in. below normal at NWS climatological station $445851 \mathrm{Mt}$. Weather resulting in a water-level recession in well 48X 20 for a majority of the year (fig. 17).
Water levels were measured quarterly in more than 40 wells from October 2002 to October 2008 (fig. 15) to document seasonal and temporal changes across the county and to provide current hydrologic conditions for droughtresponse planning. A majority of these wells were finished as open holes in the bedrock. Where possible, sites with a single water-bearing zone reported on well-completion reports were selected to provide hydraulic head for the respective depths and to minimize compositing of hydraulic heads from multiple zones. The seasonal water-level fluctuations measured between October 2002 and October 2008 probably represent a reasonable range for expected hydrologic conditions as indicated by record maximum and minimum water levels established at well 46W175 during this same period. Water-level fluctuations in all the wells measured during this time period ranged from 2.86 to $87.84 \mathrm{ft}$ with an average of $24.15 \mathrm{ft}$ (appendix 3). Generally, water-level fluctuations were greatest in recharge areas (near hydrologic divides and in isolated elevated areas) and in the Opequon Creek Basin (fig. 18). Water levels in discharge areas (near streams and springs) tend to fluctuate less (fig. 18).
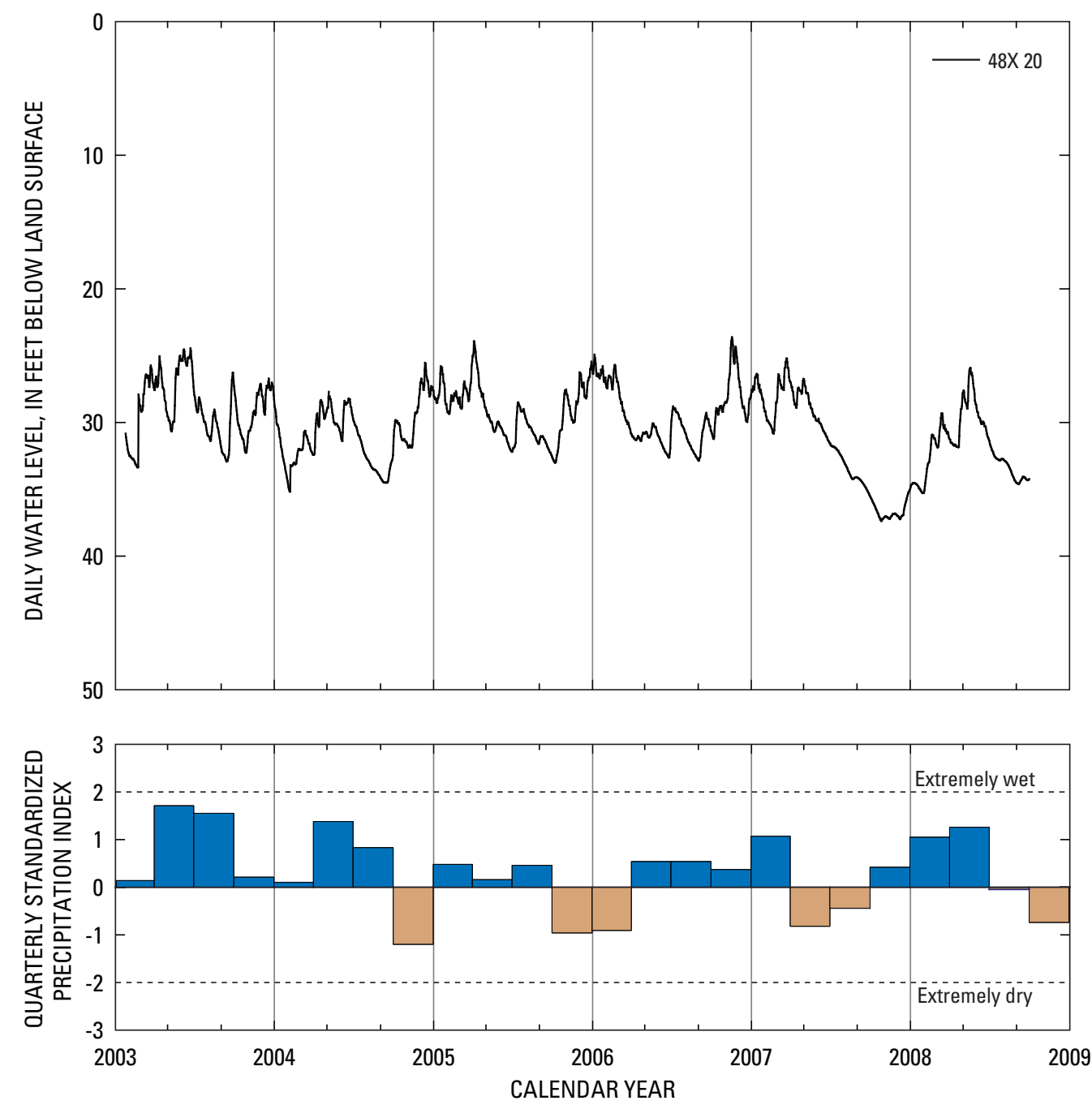

Figure 17. Relation between daily water levels in wells 48X 20 and quarterly standardized precipitation index at National Weather Service climatological station 445851 Mt. Weather, Virginia. 

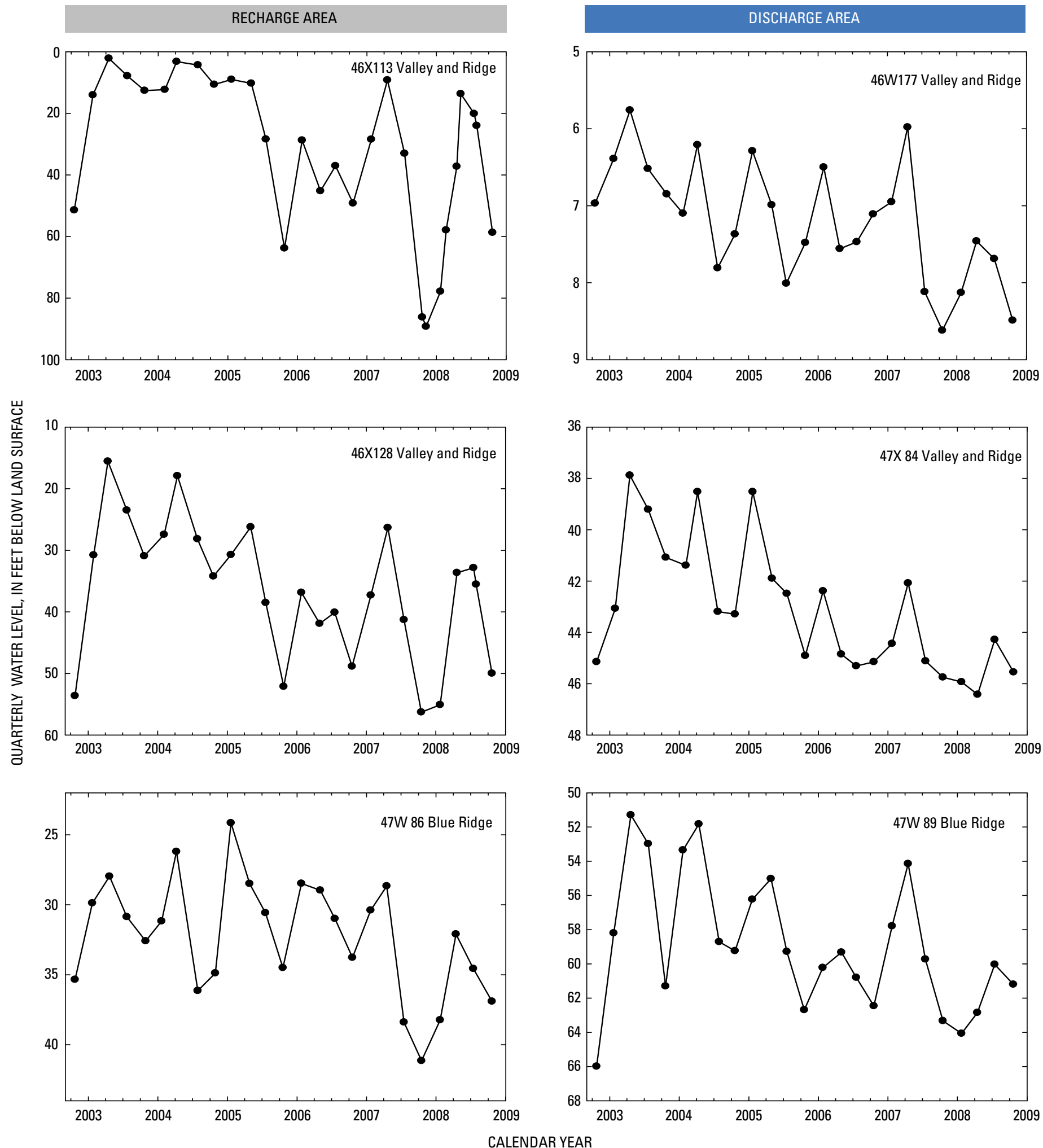

Figure 18. Quarterly water levels from selected wells located in recharge and discharge areas of the Valley and Ridge and Blue Ridge Physiographic Provinces in Clarke County, Virginia. 
The very shallow water levels measured in well 46X113 during calendar years 2003-2004 suggest periods of semi-confined conditions when the height of the hydraulic head in the upgradient parts of a basin is primarily controlled by the outlets (springs) of the groundwater flow systems.

Seasonal water-level highs typically occur in the early spring at the end of the major groundwater recharge period, and lows occur in late autumn when evapotranspiration rates begin to decrease. The overall downward trend in water levels between 2003 and 2008 observed in wells 46W175 and 46W179 is evident in most of the quarterly measured wells in the Great Valley and in wells finished in the Lower Cambrian metamorphic rocks of the Blue Ridge (fig. 18). No overall downward trend was observed in the quarterly wells finished in the Catoctin Formation, but cycles similar to those described for well 48X 20 were observed.

Water-table maps were constructed from the quarterly water-level measurements and from spring and stream altitudes. Flow conditions of streams and springs were noted during quarterly measurements, and altitude values were assigned accordingly. Approximation of the water table for April 2003 (fig. 19) and October 2007 (fig. 20) were constructed to represent periods of high and low groundwater conditions, respectively. The assigned altitudes of the streams from the 10-meter (m) DEM and the spring altitudes were used to construct the water table for April 2003. The arbitrary amount of $10 \mathrm{ft}$ was subtracted from the altitudes of the dry stream segments and dry springs to construct the October 2007 water-table map. The difference in configuration of the water table between these two periods is subtle. The area of the water-table high (altitudes between 600 and 750) beneath the Limestone Ridge that divides the Opequon Creek and Shenandoah River Basins is slightly smaller in October 2007 than in April 2003. In addition, water-table altitudes between 350 and $500 \mathrm{ft}$ move further up in the Opequon Creek and Dry Marsh Run Basins, which can explain the numerous dry stream segments and springs in this part of the county. Changes in the water table in the Shenandoah River Basin are even more subtle because the river exerts a strong regional control on the groundwater flow system and water-level fluctuations tend to be less in both the Great Valley and Blue Ridge over the same period.

Theoretically, groundwater flows perpendicular to watertable contours (figs. 19 and 20). Wright (1990) stated that the geologic structure in the Great Valley section controls groundwater flow and directions of flow may not always be perpendicular to the water-table contours. Users of the water-table maps in this part of the county should consider that dominant flow directions are along strike; therefore, hydraulic gradients may differ with respect to strike direction. In the Great Valley section of the county, hydraulic gradients are approximately 20 and 40 feet per mile (ft/mi) along and normal to strike, respectively, which may explain the relatively slow travel times determined from dye-tracer studies (Jones, 1987; Wright, 1990). In the Opequon Creek Basin, hydraulic gradients are generally low, but steepen rapidly near streams and springs in the lower entrenched reaches of the basin. Hydraulic gradients of hundreds of feet per mile in the Blue Ridge reflect the steep terrain and low permeability of the rock.
Vertical hydraulic gradients were evaluated at three wellpair sites. The largest ranges of water-level fluctuations $(87.08$ and $87.84 \mathrm{ft}$ ) measured were from wells 46X112 and 46X113, respectively. These wells are located in the northwest part of Clarke County near Stones Chapel (fig. 15). These wells are approximately $50 \mathrm{ft}$ apart, in an elevated, flat area with difference in altitude of less than $1 \mathrm{ft}$. Well $46 \mathrm{X} 112$ is $145 \mathrm{ft}$ deep and was reported to have either diminished yield or to have been dry in early 2002. Well 46X113 is $500 \mathrm{ft}$ deep and was drilled in March 2002. The reported water-bearing zone in well 46X112 is $135 \mathrm{ft}$ bls, and the reported water-bearing zone in well 46X113 is $475 \mathrm{ft}$ bls. Differences in hydraulic head were upward throughout the period and were generally less than $1 \mathrm{ft}$, except during low-water conditions when the magnitude of upward vertical hydraulic gradients increases (fig. 21). A similar relation is observed between wells $46 \mathrm{X} 8$ and 46X123, which are approximately $120 \mathrm{ft}$ apart and are located west of Berryville (fig. 15). Well 46X 8 is a 6-in.diameter well drilled to $185 \mathrm{ft}$ with no water-bearing zones reported, and well $46 \mathrm{X} 123$ is a 6-in.-diameter well drilled to $420 \mathrm{ft}$ with a single water-bearing zone reported at $290 \mathrm{ft}$. The vertical hydraulic gradients observed in these two wells are negligible (fig. 21). Both of these well pairs indicate that hydraulic heads are similar regardless of the depths of the water-bearing zones and that vertical hydraulic gradients are extremely low. This is to be expected because of the steep dips of the different geologic structures in this part of the county. The well pair located near Stones Chapel also indicates that during dry or drought conditions hydraulic head is lowered in the upper parts of the system, which is consistent with an aquifer system that fills upward from the lower or base-level parts of the aquifer system.

Wells 47X 82 and 47X 83 are approximately at the same altitude and are $40 \mathrm{ft}$ apart in an area where seeps and springs are present just north of Stringtown (fig. 15). Well 47X 82 is a 35-ft deep, stone-lined hand-dug well that reportedly was constructed in the 1700s and went dry for the first time in early 2002. Well 47X 83 was drilled in March 2002 to a depth of $340 \mathrm{ft}$, with a single water-bearing zone reported at $325 \mathrm{ft}$. The ranges in water levels for these wells (8.56 and $12.35 \mathrm{ft}$, respectively) are far less than for the other two sites. Upward vertical hydraulic gradients were observed between these two wells, especially during periods of high water levels. As water levels declined, the magnitude of the vertical hydraulic gradient decreased and occasionally reversed to become downward (fig. 21). The overall upward hydraulic gradient and relatively small range in water levels are characteristic of a discharge area. Frequently, the term "perched aquifers" is used to describe the aquifer systems in the Great Valley; however, this well pair and the nearby seeps and springs indicate that the regolith mantle and underlying bedrock are connected. Many areas that might be interpreted as perched aquifers may simply be depression storage in small ponds that may or may not be associated with sinkholes. During drought conditions, vertical hydraulic gradients can be an order of magnitude larger than the horizontal gradients described earlier. 


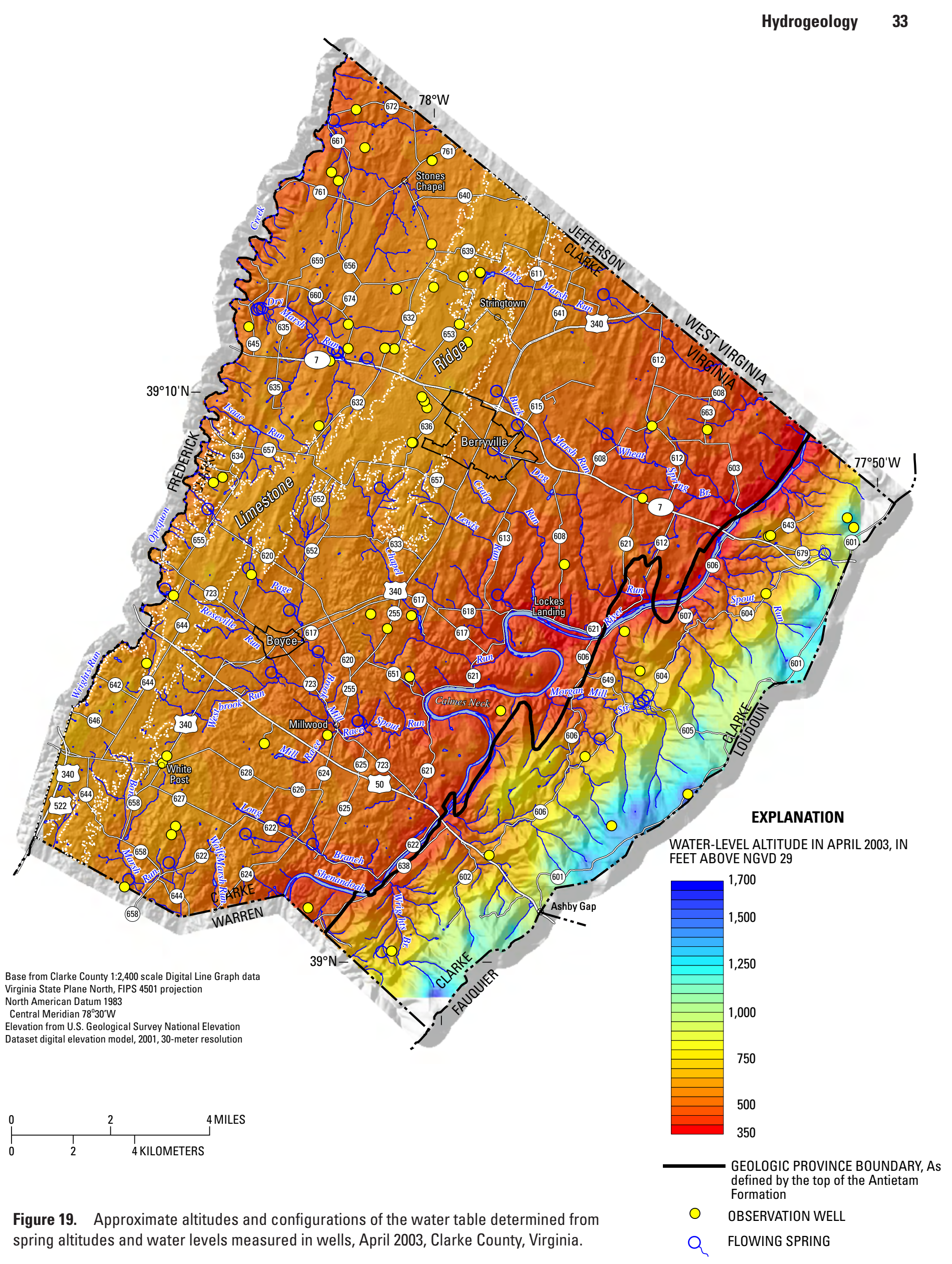




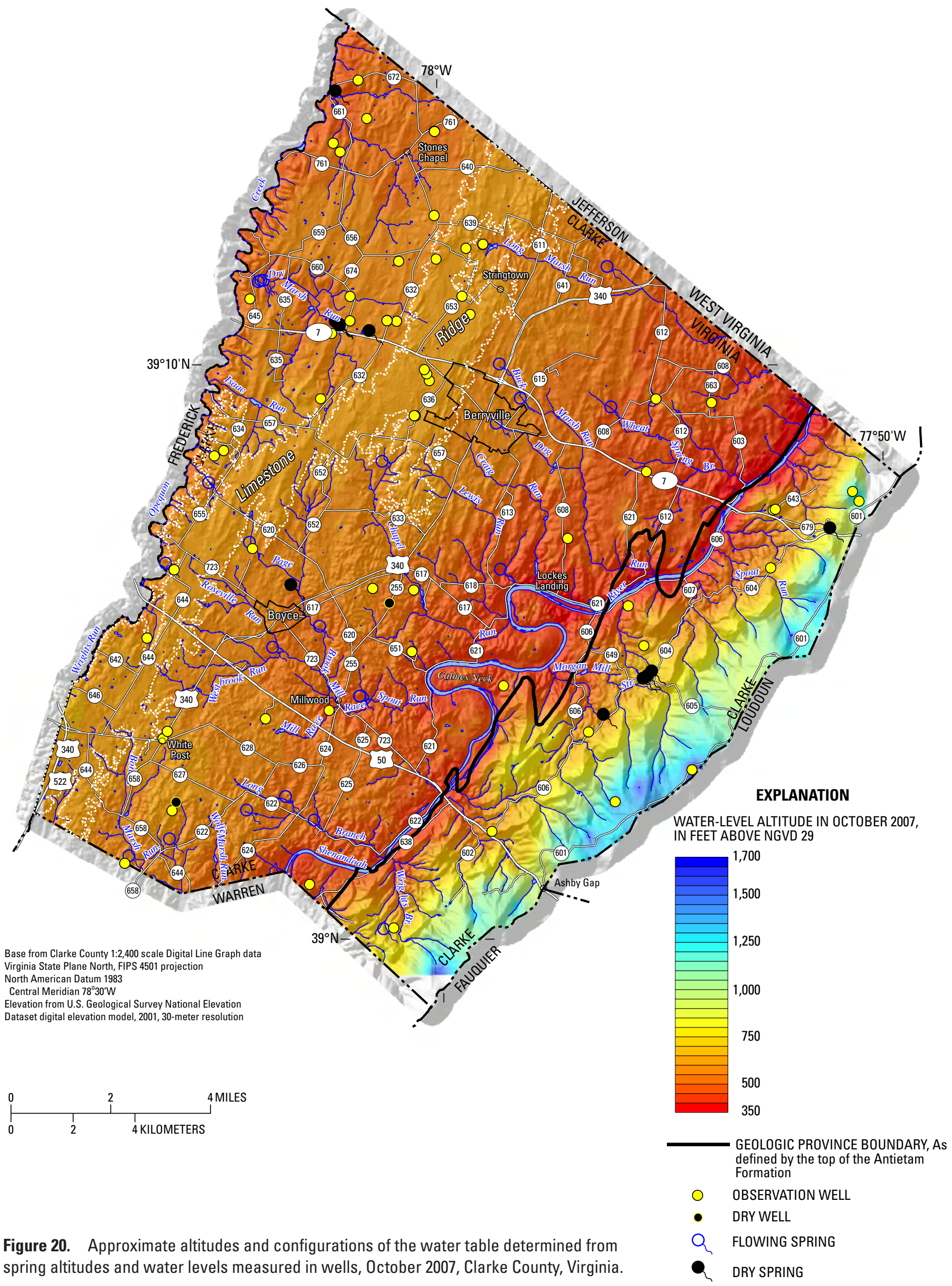



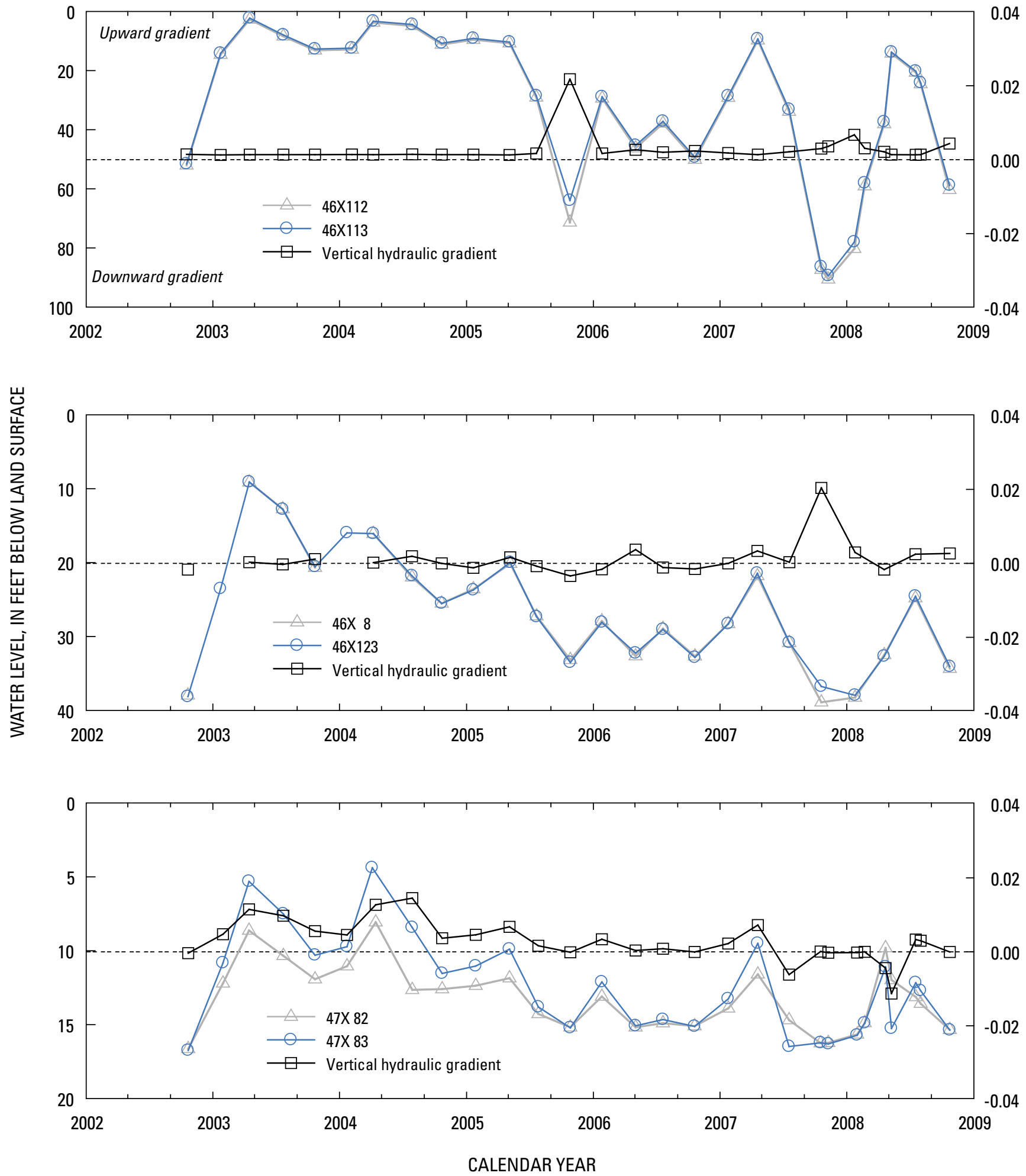

Figure 21. Vertical hydraulic gradients in the Great Valley section of Clarke County, Virginia, between 0 ctober 2002 and 0 ctober 2008. 


\section{Streamflow and Spring Discharge}

Groundwater discharges from the aquifer systems in Clarke County as base flow to streams and as spring discharge. A large part of streamflow is groundwater discharge (base flow) during low- and high-flow conditions. Springs commonly form the headwaters of many of the streams in the county. Dry stream segments during drought conditions are usually the result of cessation of flow from an upstream spring. A long-term network to monitor streamflow and spring discharge was established during this investigation. Two streamflow gaging stations were established: 01616100 (Dry Marsh Run near Berryville) and 01636316 (Spout Run at Route 621 near Millwood; fig. 15). Flow-duration statistics, which are used to assess current hydrologic conditions, indicate that mean annual streamflow for water years 2002-2007 averaged 12.4 and 25.1 cubic feet per second $\left(\mathrm{ft}^{3} / \mathrm{s}\right)$ at streamflow gages 01616100 and 01636316 , respectively. Drainage areas for these basins are 11.0 and $21.4 \mathrm{mi}^{2}$, respectively. Thus, discharge averaged over these basins is about 15 percent more than the $1 \mathrm{ft}^{3} / \mathrm{s}$ of flow per square mile of drainage area typically observed in long-term records for basins in the midAtlantic region of the United States (Poff, 1999).

Pressure transducers were installed at three springs (fig. 15) - 46WS 1 (Carter Hall), 46WS 3 (Prospect Hill), and 46WS 22 (Saratoga) — to estimate continuous spring discharge. Stage-discharge ratings were developed to calculate discharge for springs 46WS 1 and 46WS 22; however, a similar rating for spring 46WS 3 was unsuccessful because of water withdrawals and physical characteristics of the structure constructed over the spring. Spring 46WS 1 (fig. 22) was the largest spring measured in the county with discharges that ranged from 3.02 to $10.0 \mathrm{ft}^{3} / \mathrm{s}$ and a mean annual discharge of $5.16 \mathrm{ft}^{3} / \mathrm{s}$, which indicates that the drainage area is approximately $5 \mathrm{mi}^{2}$ based on an average discharge of $1 \mathrm{ft}^{3} / \mathrm{s}$ of flow per $1 \mathrm{mi}^{2}$. Discharge at spring 46WS 22 ranged from 0.30 to $1.98 \mathrm{ft}^{3} / \mathrm{s}$ with a mean annual discharge of $0.85 \mathrm{ft}^{3} / \mathrm{s}$, indicating that the spring probably drains an area slightly less than $1 \mathrm{mi}^{2}$. The average drainage area for spring 46WS 3 can be approximated from the 23 quarterly measurements that ranged from 1.16 to $3.06 \mathrm{ft}^{3} / \mathrm{s}$. The mean discharge of these measurements is $2.03 \mathrm{ft}^{3} / \mathrm{s}$, which indicates a drainage area of about $2 \mathrm{mi}^{2}$. As discussed earlier and as determined by Jones (1987), flow to springs is not controlled by surface-water divides, but probably is controlled by the geologic structure. Future efforts to delineate drainage areas for these springs, as well as for the other springs discussed below, can use mean discharge to approximate the size of the area needed to provide the respective discharge.

Spring discharge and field water-quality properties were measured quarterly at 6 and 16 sites in the Blue Ridge and Great Valley section, respectively (fig. 15). Streamflow gaging stations 01636283 (Wrights Branch Tributary below Jeep Trail near Stone Bridge) and 01636336 (Buck Marsh Run above Highway 340 at Berryville) were included in the spring monitoring network because streamflow at each of these stations is from several springs a short distance upstream from the measuring section. Wright (1990) stated that discharges from springs in the Great Valley are greater than those in the Blue Ridge because of the well-developed system of solutionenlarged fractures and less steep terrain. Discharge at the Blue Ridge springs ranged from dry to $0.41 \mathrm{ft}^{3} / \mathrm{s}$ with an average discharge of $0.04 \mathrm{ft}^{3} / \mathrm{s}$ from 2003 to 2008 (appendix 4). During the same time period, discharge at the Great Valley springs ranged from dry to $4.47 \mathrm{ft}^{3} / \mathrm{s}$ with an average discharge of $0.58 \mathrm{ft}^{3} / \mathrm{s}$. The seasonality of discharge is evident in the hydrographs (fig. 22). The highest discharges occur in winter and early spring when $E T$ is at minimum, and discharge generally declines into late autumn. An overall downward trend in spring discharge is evident in nearly every spring monitored in the Great Valley between 2003 and 2008. This downward trend correlates with the similar trend documented in water levels and is indicative of an aquifer system that drains over time to a base level controlled by springs and streams. A similar trend is not readily identifiable for the springs in the Blue Ridge because of the relatively low discharge rates, probable small drainage areas, and the susceptibility of these aquifer systems to current meteorological conditions.

As discussed earlier, review of mean discharges provides an estimate of drainage area. In the Blue Ridge, delineation of a spring's drainage area based on surface-water divides provides sufficient area to supply the mean discharge and probably represents the contributing area to the spring. In the Great Valley, mean discharge only provides a guide for the size of the area needed. Wright (1990) stated that these estimates of discharge per unit area may not represent an easily definable or discrete area surrounding a spring.

From 2003 to 2008, several springs had periods when flow ceased (fig. 22). Springs in the Blue Ridge are especially susceptible to successive periods of below-normal precipitation. Abundant precipitation during the winter/early spring recharge period, however, can cause rapid percolation through the overburden and transmission to springs (Wright, 1990). Evidence of this is shown by the nearly threefold increase in discharge at spring 01636320 in 2004 . During extended dry periods, many springs in the Great Valley, especially in the upper reaches of the basins, ceased flowing. Spring 46XS 8 best illustrates the magnitude of intermittent flow observed during 2003-2008. This spring was reported to be dry during the prolonged drought between 1999 and 2002, and aerial photography collected in 2002 by the Virginia Base Mapping Program clearly shows no discharge from the spring and shows dry stream segments for approximately $1 \mathrm{mi}$ downstream. Flow from spring 46XS 8 resumed sometime between November 2002 and January 2003 after nearly 9 months of abovenormal precipitation, but slowly declined into late autumn of 2003. By April 2004, a discharge of $4.47 \mathrm{ft}^{3} / \mathrm{s}$ was measured at spring 46XS 8, which was the highest discharge at this site during 2003-2008. Dry flow conditions have prevailed for a majority of the time after April 2004 because precipitation was below normal most of the time between April 2004 and October 2008. 

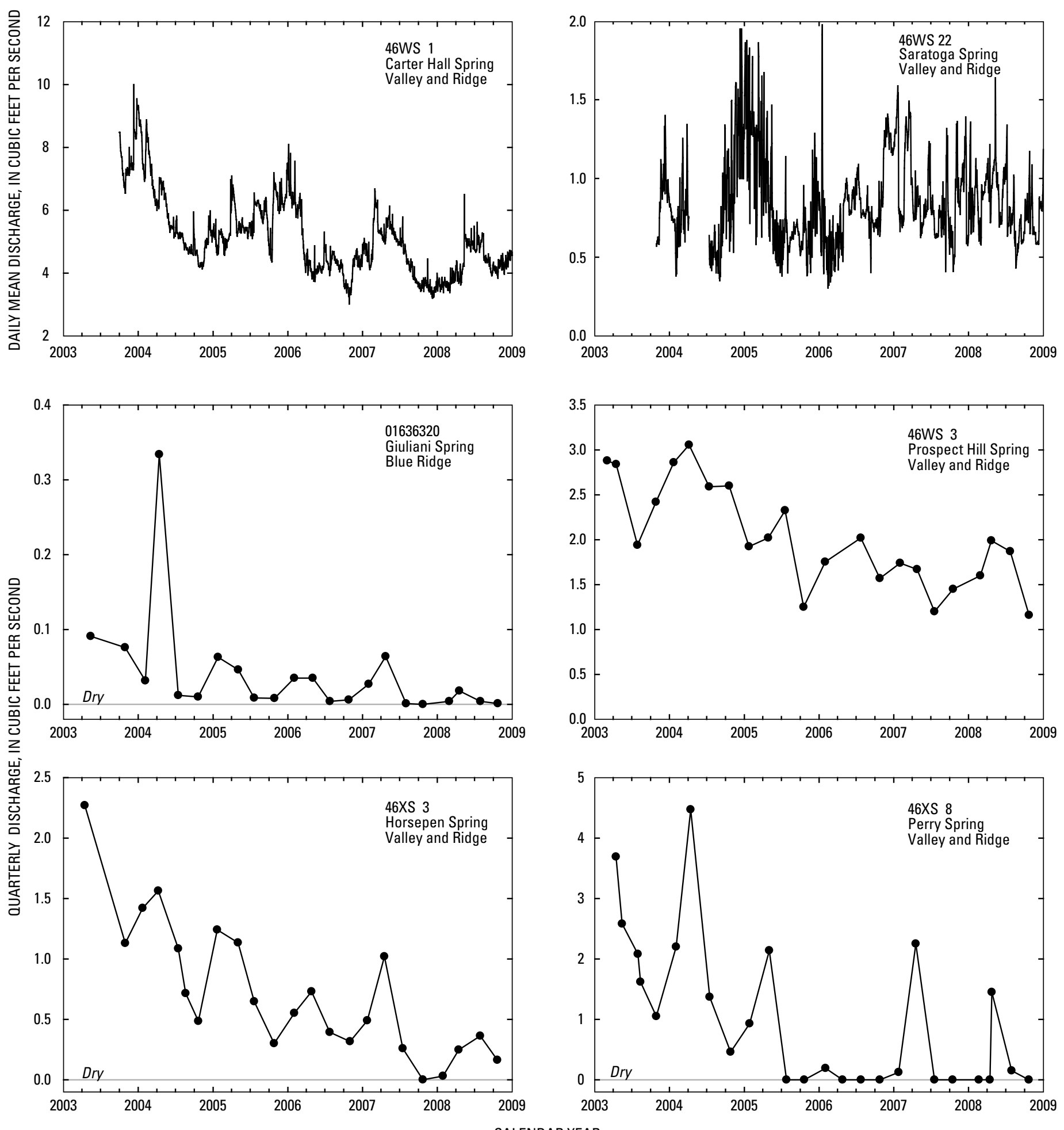

Figure 22. Daily mean and quarterly discharges from selected springs in Clarke County, Virginia, between April 2003 and October 2008. 
Evaluation of intermittent flow conditions in the Great Valley section of the county provides insight into the manner in which the aquifer system recharges, stores, and discharges groundwater. Quarterly water temperature measurements at spring 46XS 8 only ranged from 12.1 to $12.8^{\circ} \mathrm{C}$ during 20032008, which indicates that groundwater generally has equilibrated to the average annual ambient temperature of the shallow subsurface rocks and is not influenced by rapid movement of direct inflow from surface sources such as sinking streams and sinkholes. A thermister was placed at the outlet of spring 46XS 8 (fig. 15) in December 2005 after a period of nearly 6 months of no flow. An additional thermister was placed approximately $2 \mathrm{ft}$ above the existing water line in a depression located $0.84 \mathrm{mi}$ downstream along Dry Marsh Run that is believed to be an estavelle. The air-water temperature record for spring 46XS 8 and the estavelle are shown in figure 23 in relation to daily air temperature and precipitation at NWS climatological station 449186 Winchester 7 SE. The upward shift in water temperature on December 26, 2005, at the estavelle site is interpreted as inflow of Dry Marsh Run from several springs a few hundred feet upstream. From late December 2005 to late January 2006, daily temperature fluctuations tended to respond slightly to daily changes in air temperature and precipitation. These fluctuations oscillated around $10.5^{\circ} \mathrm{C}$, which indicates that the temperature of the water discharging from the upstream springs changes in Dry Marsh Run prior to flowing into the estavelle. The water temperature record at spring 46XS 8 nearly mimics the daily range of air temperatures at NWS climatological station 449186 until January 19, 2006, when the spring probably flowed again and the temperature at the spring increased and remained at a constant temperature of $12.8^{\circ} \mathrm{C}$. The warm temperature is characteristic of groundwater temperatures, which tend to be warmer than air temperatures in the winter months and colder than air temperatures in the summer months. Flowing conditions in early February 2006 were noted at both sites when the thermisters were retrieved, and the measured discharge at spring 46XS 8 was $0.19 \mathrm{ft}^{3} / \mathrm{s}$. The nearly 1 -month offset in the start of flow between these two sites indicates that the aquifer system fills from the lower to the upper reaches of the basin. However, the filling of the aquifer system follows the geologic structure and is expected to fill from the lower reaches in the north to the upper reaches in the south (fig. 5).

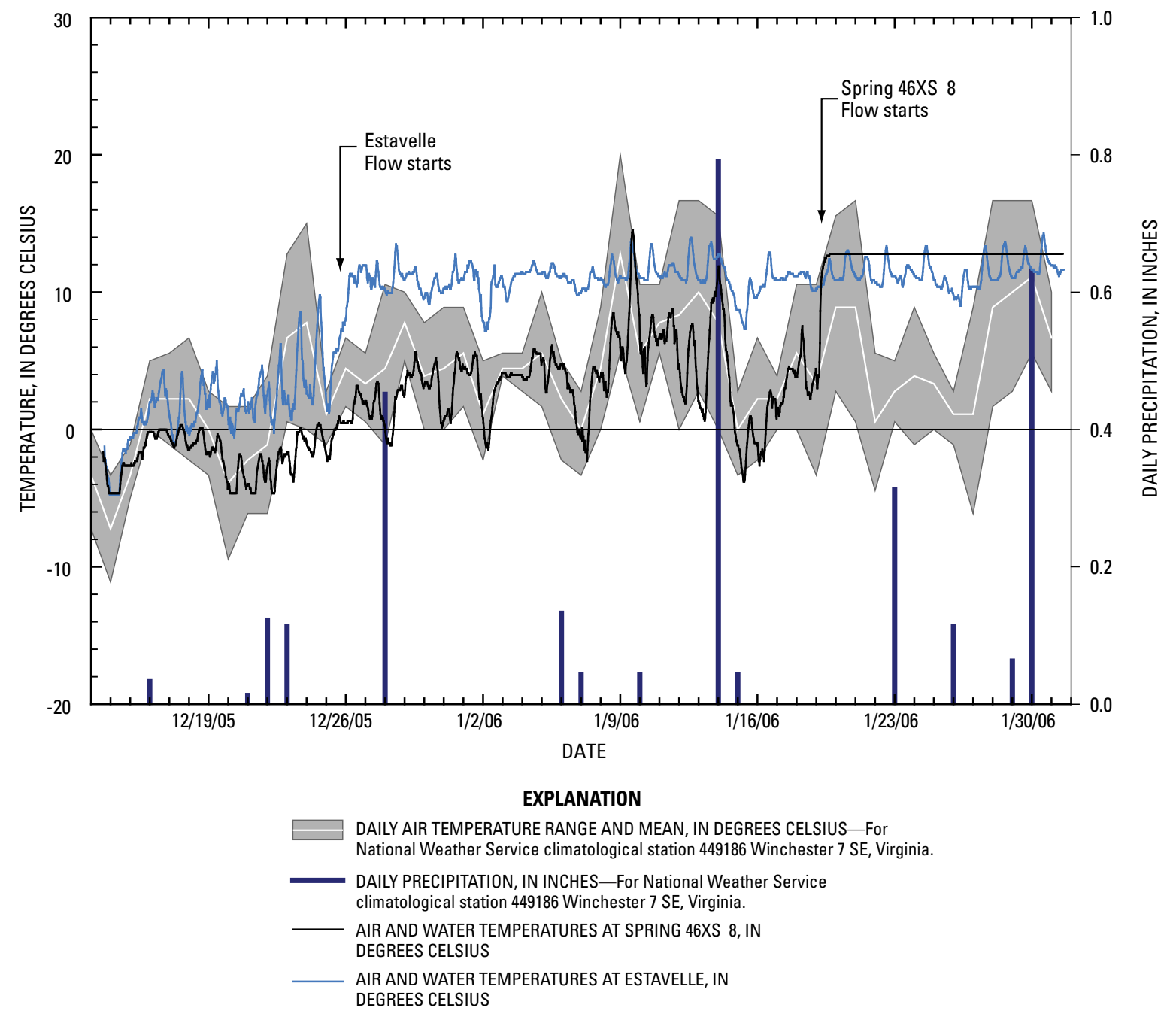

Figure 23. Relation between daily air temperature and precipitation at National Weather Service climatological station 449186 Winchester 7 SE and air and water temperatures at spring 46XS 8 and estavelle located 0.84 mi west of spring 46XS 8 in Clarke County, Virginia. 


\section{Groundwater Areas}

Clarke County was divided into nine groundwater areas based on surface-water basin boundaries (fig. 24). Delineation of these groundwater areas could assist future watermanagement activities because each area contains similar physical, geologic, and hydrologic characteristics (table 2). In the Blue Ridge section of the county, the boundaries of the three groundwater areas may mimic the boundaries of the individual groundwater flow systems because the conceptual model for this part of the county assumes groundwater divides generally are closely related to the surface-water divides. In the Great Valley section of the county, the groundwater areas only represent areas with similar characteristics and not necessarily groundwater boundaries because flow beneath surfacewater divides has been observed (Jones, 1987).

The Blue Ridge groundwater areas are characterized by high altitudes with relief greater than 1,400 ft, steep slopes,

Table 2. Physical and geologic characteristics of the groundwater areas in Clarke County, Virginia.

[Min, minimum; Max, maximum; np, not present. Shaded rows indicate Blue Ridge areas, and unshaded rows indicate Valley and Ridge areas. See figure 24 for location of groundwater areas]

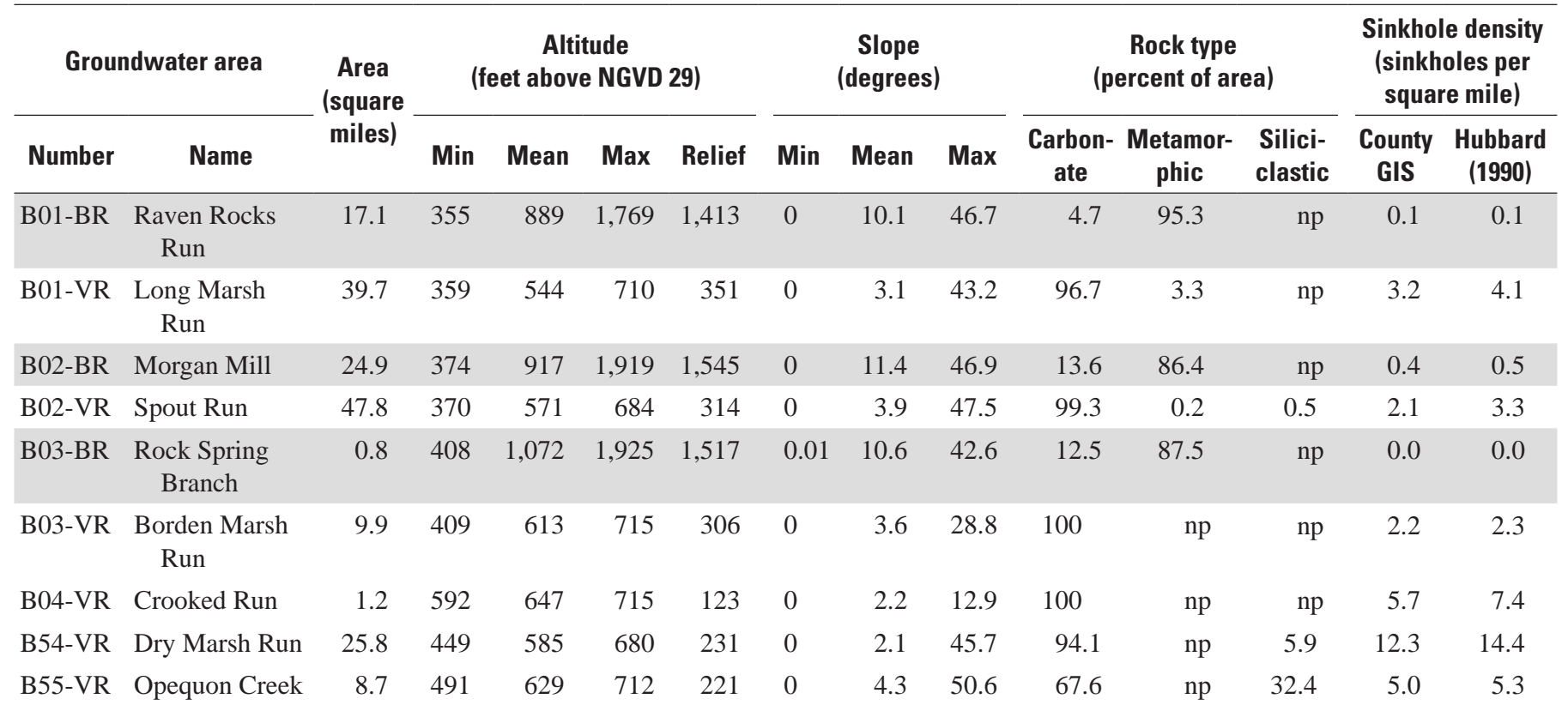

\begin{tabular}{|c|c|c|c|c|c|c|c|c|c|}
\hline \multirow{2}{*}{\multicolumn{2}{|c|}{ Groundwater area }} & \multicolumn{4}{|c|}{$\begin{array}{c}\text { Stream density } \\
\text { (miles per square mile) }\end{array}$} & \multirow{2}{*}{\multicolumn{4}{|c|}{$\begin{array}{c}\text { Annual precipitation } \\
\text { (inches per year) }\end{array}$}} \\
\hline & & \multirow{2}{*}{ Area } & \multicolumn{3}{|c|}{ Rock type } & & & & \\
\hline Number & Name & & Carbonate & Metamorphic & Siliciclastic & Min & Mean & Max & Range \\
\hline B01-BR & $\begin{array}{l}\text { Raven Rocks } \\
\text { Run }\end{array}$ & 1.97 & 0.05 & 1.93 & np & 39.0 & 40.9 & 42.4 & 3.4 \\
\hline B01-VR & $\begin{array}{l}\text { Long Marsh } \\
\text { Run }\end{array}$ & 1.24 & 1.11 & .13 & np & 38.9 & 39.3 & 40.3 & 1.4 \\
\hline B02-BR & Morgan Mill & 2.1 & 0.16 & 1.95 & np & 39.1 & 40.9 & 42.6 & 3.5 \\
\hline B02-VR & Spout Run & 1.78 & 1.76 & .01 & 1.69 & 38.9 & 39.2 & 39.9 & 1.0 \\
\hline B03-BR & $\begin{array}{c}\text { Rock Spring } \\
\text { Branch }\end{array}$ & 1.76 & .08 & 1.69 & np & 40.6 & 41.6 & 42.5 & 1.9 \\
\hline B03-VR & $\begin{array}{l}\text { Borden Marsh } \\
\text { Run }\end{array}$ & 1.81 & 1.81 & $\mathrm{np}$ & $\mathrm{np}$ & 39.1 & 39.3 & 39.5 & 0.4 \\
\hline B04-VR & Crooked Run & 1.82 & 1.82 & $\mathrm{np}$ & $\mathrm{np}$ & 39.2 & 39.2 & 39.2 & 0.0 \\
\hline B54-VR & Dry Marsh Run & 1.41 & 1.32 & np & 0.09 & 38.9 & 39.1 & 39.6 & 0.7 \\
\hline B55-VR & Opequon Creek & 1.77 & 0.98 & np & 0.79 & 38.9 & 39.0 & 39.1 & 0.2 \\
\hline
\end{tabular}




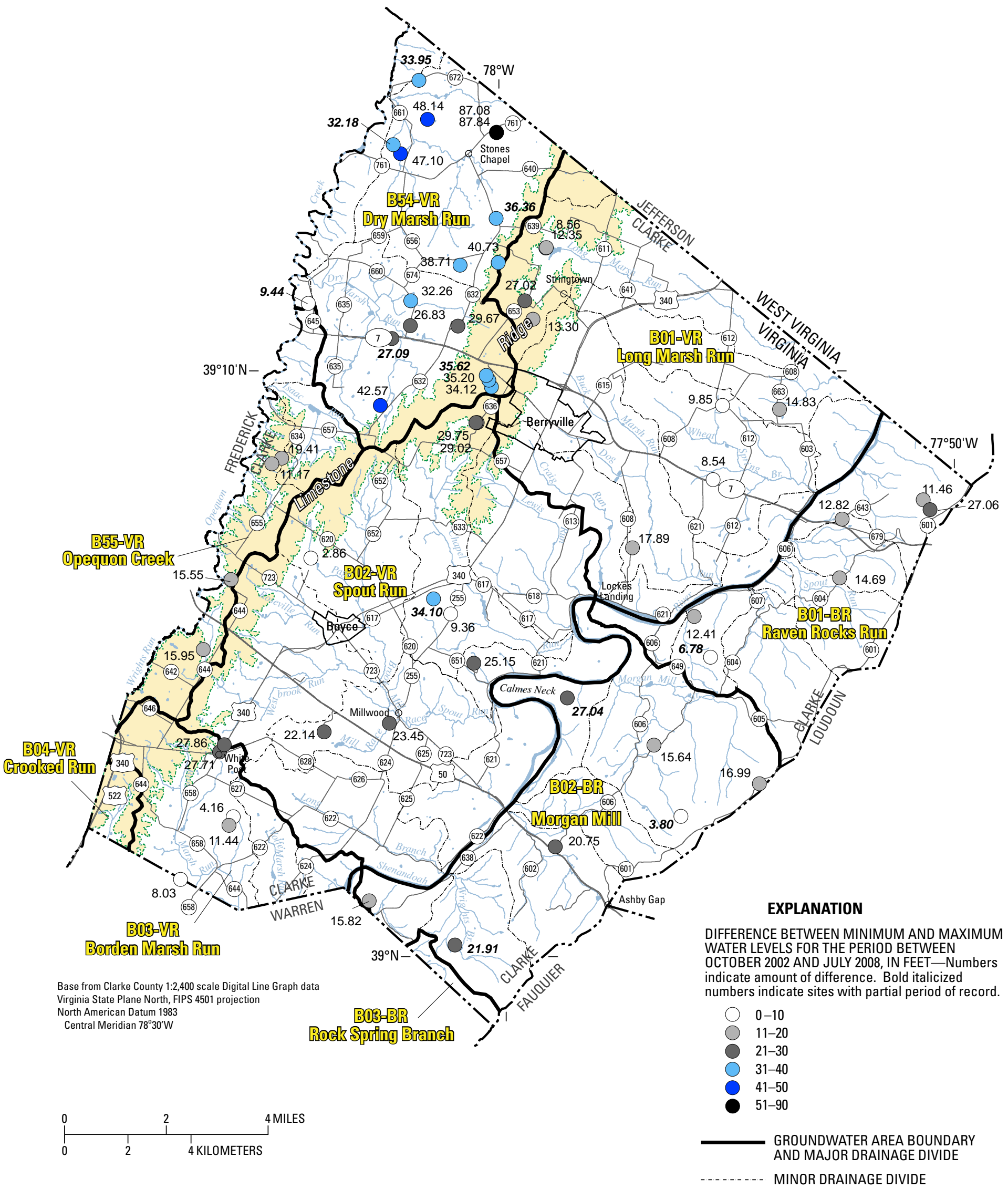

Figure 24. Location of groundwater areas and difference between minimum and maximum water levels for the period between October 2002 and July 2008 in Clarke County, Virginia. 
low sinkhole density, high stream density, mean annual precipitation of about 41 inches per year (in/yr), and relatively large differences between minimum and maximum annual precipitation across the areas (table 2). The Great Valley groundwater areas are characterized by low altitudes with relief generally less than $350 \mathrm{ft}$, gentle slopes, high sinkhole density, low stream density, mean annual precipitation of about $39 \mathrm{in} / \mathrm{yr}$, and less variability in precipitation across the areas (table 2). The difference in mean annual precipitation within and between groundwater areas, and even across the county, may seem small, but 1 in. of precipitation across $1 \mathrm{mi}^{2}$ is equivalent to 17.4 million gallons.

The orographic effect of the elevated areas on precipitation in Blue Ridge is evident; lower annual precipitation values (less than $40 \mathrm{in} / \mathrm{yr}$ ) are present at the lower altitudes, and the higher values (greater than $40 \mathrm{in} / \mathrm{yr}$ ) are present at the higher altitudes. Precipitation that percolates into the subsurface flows rapidly as interflow or subsurface stormflow along steep gradients to the relatively dense stream network (Wright, 1990). Although precipitation is generally less in the Great Valley, the combination of gentle slopes, low relief, and more permeable rock types, as indicated by the low stream density (Olmsted and Hely, 1962; Hely and Olmsted, 1963; Hack, 1965), facilitates flow of water from the surface downward to the water table. The parts of the groundwater areas in the Great Valley underlain by siliciclastic rocks, however, have characteristics that are more similar to the Blue Ridge areas.

In general, the magnitude of water-level fluctuations tends to be controlled by the topography of the groundwater areas (fig. 24). Water-level fluctuations are greatest near the groundwater area boundaries in the upper reaches, under isolated elevated areas within the groundwater areas, and in areas where the low-order streams parallel the strike of the rocks (Dry Marsh Run area). The ranges between the minimum (highest) and maximum (lowest) water levels measured between October 2002 and October 2008 are greatest in the Dry Marsh Run groundwater area (fig. 24). Numerous geologic structures (faults and lineament zones) cross and intersect in the Dry Marsh Run area. Low stream density and large water-level fluctuations suggest that the area is underlain by permeable rocks; the relatively deep water-bearing zones and the occurrence of numerous faults and lineament zones (figs. 13 and 14) suggest that permeability may be present to considerable depth. High permeability extending to depth and large water-level fluctuations can explain why the density of sinkholes in this area is more than twice the densities determined for the other Great Valley groundwater areas, numerous stream segments are dry a majority of the time, and numerous wells went dry during the prolonged drought during 1999-2002. These factors likely are the reason that this area is locally referred to as the "Arabian Plain," and many of the old homesteads are equipped with cisterns and shallow, hand-dug wells near intermittent springs. Conversely, the Dry Marsh Run area had the largest magnitude and rate of recovery measured at the cessation of this drought. Kozar and Weary (2009) suggest that this area represents a recharge area for regional flow that ultimately discharges to the north in the vicinity of Leetown, WV.
Water-level fluctuations in the Opequon Creek groundwater area are nearly half of those in the Dry Marsh Run area (fig. 24). Possible explanations for this are (1) groundwater in the Dry Marsh area may also flow to the south towards Opequon Creek, which is opposite the topographic gradient; (2) flow out of the carbonate rocks in the Opequon Creek area may be impeded by the low permeability Martinsburg Formation, which underlies Opequon Creek (fig. 5); (3) the areas underlain by the Martinsburg Formation have low recharge rates; or (4) the Opequon Creek and Dry Marsh Run areas are independent of each other and are parts of different flow blocks. Future groundwater flow modeling efforts in this part of the county could help determine whether or not these groundwater areas are connected.

The noticeable change in drainage direction from the southerly direction in the Borden Marsh Run and Crooked Run groundwater areas to the southeast across the strike in the Long Marsh Run and Spout Run areas suggests that these areas may act as separate flow blocks. A majority of the folds in the Long Marsh Run and Spout Run areas plunge to the north-northeast, and the topographic gradient is generally in the same direction.

\section{Relation of Geology to Groundwater Flow}

In the Great Valley section, the conceptualization is that the preferred direction of groundwater flow is along strike. Therefore, the dominant direction of groundwater flow is generally from elevated areas either to the northeast or southwest along the strike of the rocks. Drainage networks in the Great Valley section of the county often follow cross joints in the rock (Hack and Young, 1959). Many of the higher order streams and creeks flow normal to strike; however, many of the low-order tributaries and the Shenandoah River and Opequon Creek generally flow parallel to the strike of the rocks especially in the northwest part of the county and the upper reaches of the Spout Run drainage. Stream density (length of streams per drainage area) is generally low for areas underlain by the permeable carbonate rocks and higher for the less permeable rock types.

In the Blue Ridge, relict structures in the regolith material provide pathways for the flow of water from elevated areas to nearby streams in the form of interflow and shallow groundwater flow where the water table is above the top of bedrock. The unconsolidated surficial materials in the riparian areas of the Blue Ridge can function as local flow systems above the fractured-rock aquifers (D.L. Nelms, U.S. Geological Survey, written commun., 2009). Groundwater flow in the bedrock of the Blue Ridge is controlled by the orientation of the foliations and joints, but dominant direction is difficult to ascertain. One possibility, suggested by Southworth (1990), is that water recharged on the western slopes of the mountains of the Blue Ridge flows down-dip and eventually discharges in springs and valleys on the eastern sides of the mountains.

Orndorff and Harlow (2002) and Harlow and others (2005) noted that springs in the Shenandoah Valley are 
structurally controlled and usually are present where fault planes intersect the surface. Numerous springs in Clarke County are present along faults and within lineament zones in both the Great Valley and Blue Ridge. Many springs, however, also are present along fold axes where joints converge. Travertine deposits commonly are present at and downstream from springs in the Great Valley and are formed by waters that are supersaturated with respect to calcium carbonate (Orndorff and Harlow, 2002).

\section{Relation Between Groundwater and Surface Water}

Often, groundwater and surface water are discussed as if these components of the flow systems were separate entities. In Clarke County, groundwater is a major component of streamflow, usually in the form of direct discharge from springs at the headwaters of streams and directly through streambeds or streambanks. In the Blue Ridge, rapid transmission of interflow, subsurface stormflow, spring discharge, and, to some degree, direct groundwater discharge from the bedrock sustain streamflow. Generally, streamflow is limited by current meteorological conditions such that periods of flow cessation frequently occur during dry periods in the late summer and early autumn. In the Great Valley section of the county, groundwater is the dominant source of streamflow during wet and drought conditions, and most of the streams and creeks start at springs. Springs 46WS 1, 46WS 3, and 46WS 22 either discharge directly to Spout Run or a tributary (fig. 15). Although discharge at these springs may vary, these springs provide a relatively continuous source of water to Spout Run (fig. 25A). During wet conditions, discharge from springs 46WS 1 and 46WS 22 accounted for approximately 30 percent of the streamflow measured at gaging station 01636316; during dry conditions, 50 to more than 80 percent of the streamflow was from the discharge of these two springs (fig. 25B). If discharge from spring 46WS 3 is included, these percentages would substantially increase, especially during periods of low flow at gage 01636316 . These three springs are not the only springs contributing flow to Spout Run, which illustrates the importance of groundwater for sustaining streamflow. When managing water resources and identifying potential contaminant sources within the county, it is important to take into account that a large portion of streamflow at different flow regimes comes directly from groundwater discharge.

Field reconnaissance of spring locations throughout the county was conducted by Wright (1990), county personnel, and also during this investigation. Identification of subaqueous spring discharge in streams and creeks, especially the
Shenandoah River, is difficult. A section of the Shenandoah River below Lockes Landing was evaluated as part of a pilot study by the USGS Groundwater Resources Program to demonstrate and assess a fiber-optic distributed temperature sensing (FO DTS) system as a method to identify groundwater discharge to streams. Lane and others (2008) state that the analysis of light backscattered from the propagation of a laser pulse along a fiber-optic line is a function of temperature, which is known as Raman scatter. An optical frequency-domain reflectometry analysis was used to estimate temperature every meter along a 300- and 1,300-m fiber-optic cable submerged to the bottom of the Shenandoah River just downstream from Lockes Landing in August 2006 (fig. 26). This time period coincides with the maximum thermal anomaly between groundwater and surface-water temperatures. The discharge of cold groundwater from a spring is evident by the thermal anomaly shown in figure $26 B$ at approximately $200 \mathrm{~m}$ along the fiber-optic cable. The thermal profile shown in figure $26 B$ was constructed by stacking individual traces that individually represent a time interval of approximately 1 minute. Local lore holds that "cold spots" in the river are areas where springs discharge. The subaqueous spring identified along the $300-\mathrm{m}$ cable is an example where this is true. A thermal anomaly was observed along the 1,300-m cable between 1,150 and $1,200 \mathrm{~m}$ (fig. 27) during the late afternoon of August 8, 2006. After sunset, the temperature along the entire fiber decreased, and the anomaly was no longer evident. The thermal anomaly coincides with the area where a depression in the streambed of approximately $2 \mathrm{~m}$ is present, and the anomaly is the result of differential heating during the daylight hours that is depth dependent. For the most part, streams, creeks, and rivers simply function as aqueducts. In the carbonate terrains, surface-water flow often is a source of recharge to the groundwater system by inflow through sinkholes, swallet or swallow holes, streambeds (sinking streams), and estavelles.

A similar relation between groundwater and surface water exists in the Blue Ridge section of the county, except the overburden or regolith material overlying the bedrock plays a more important role than in the Great Valley section. Wright (1990) emphasized the importance of subsurface stormflow in the overburden that can rapidly transmit water to springs and streams in the Blue Ridge. The porous nature of the regolith material in the stream valleys is conducive for infiltration, movement, and temporary storage of subsurface water. Although this water can be considered groundwater, in reality, the subsurface stormflow and, to some degree, interflow are probably representative of water in the overburden and not of water in the bedrock as evidenced by the seasonality of flow conditions and rapid response to extreme precipitation events. 

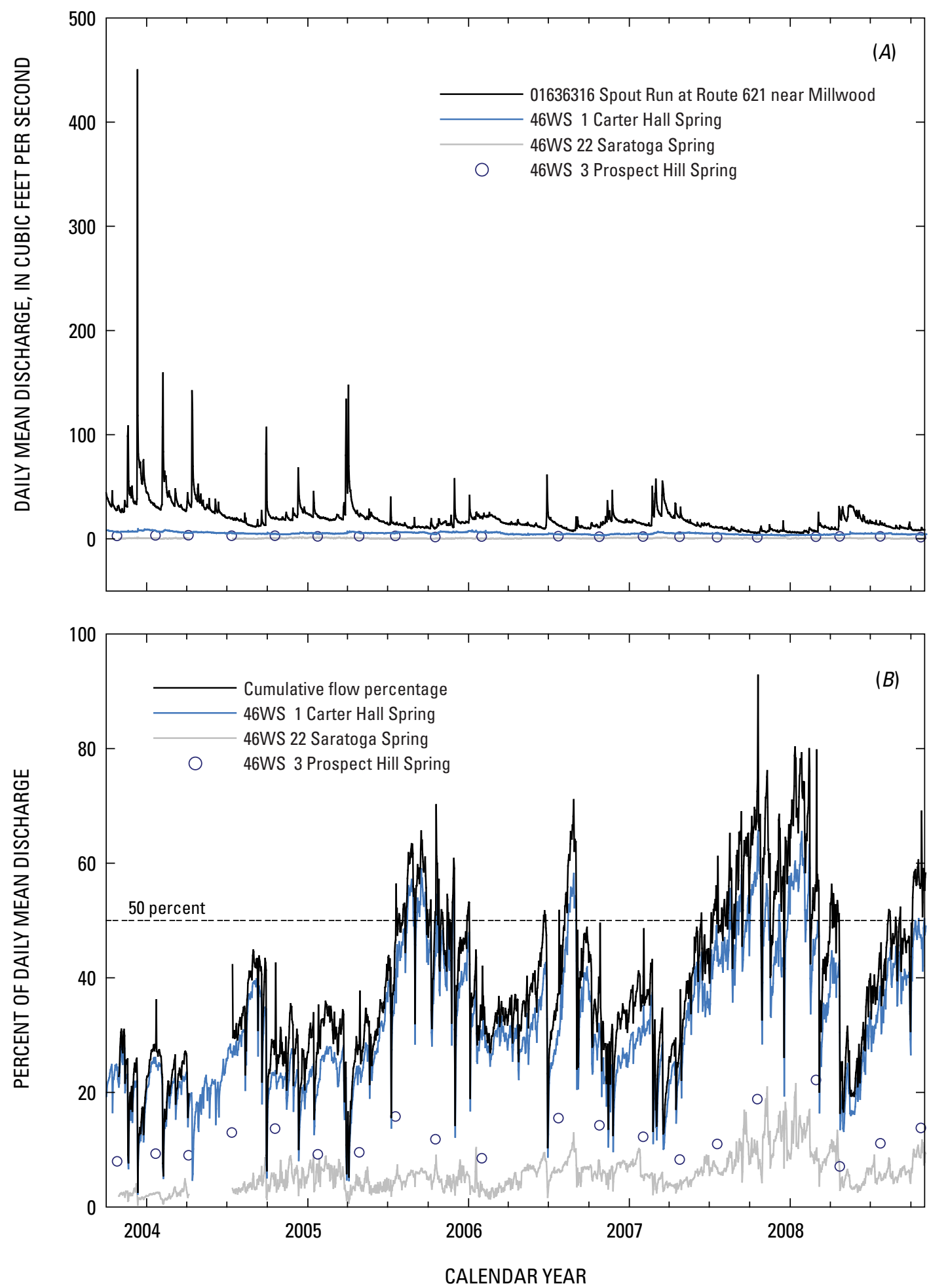

Figure 25. Relation between $(A)$ daily mean discharge and $(B)$ percent of daily mean discharge at streamflow gaging station 01636316 Spout Run at Route 621 near Millwood, Virginia, and 46WS 1 Carter Hall and 46WS 22 Saratoga Springs in Clarke County, Virginia. Cumulative flow percentage is based on combined daily mean discharge from springs 46WS 1 and 46WS 22 and is not shown when data are missing. Quarterly discharge measurements for 46WS 3 Prospect Hill Spring included for reference. 


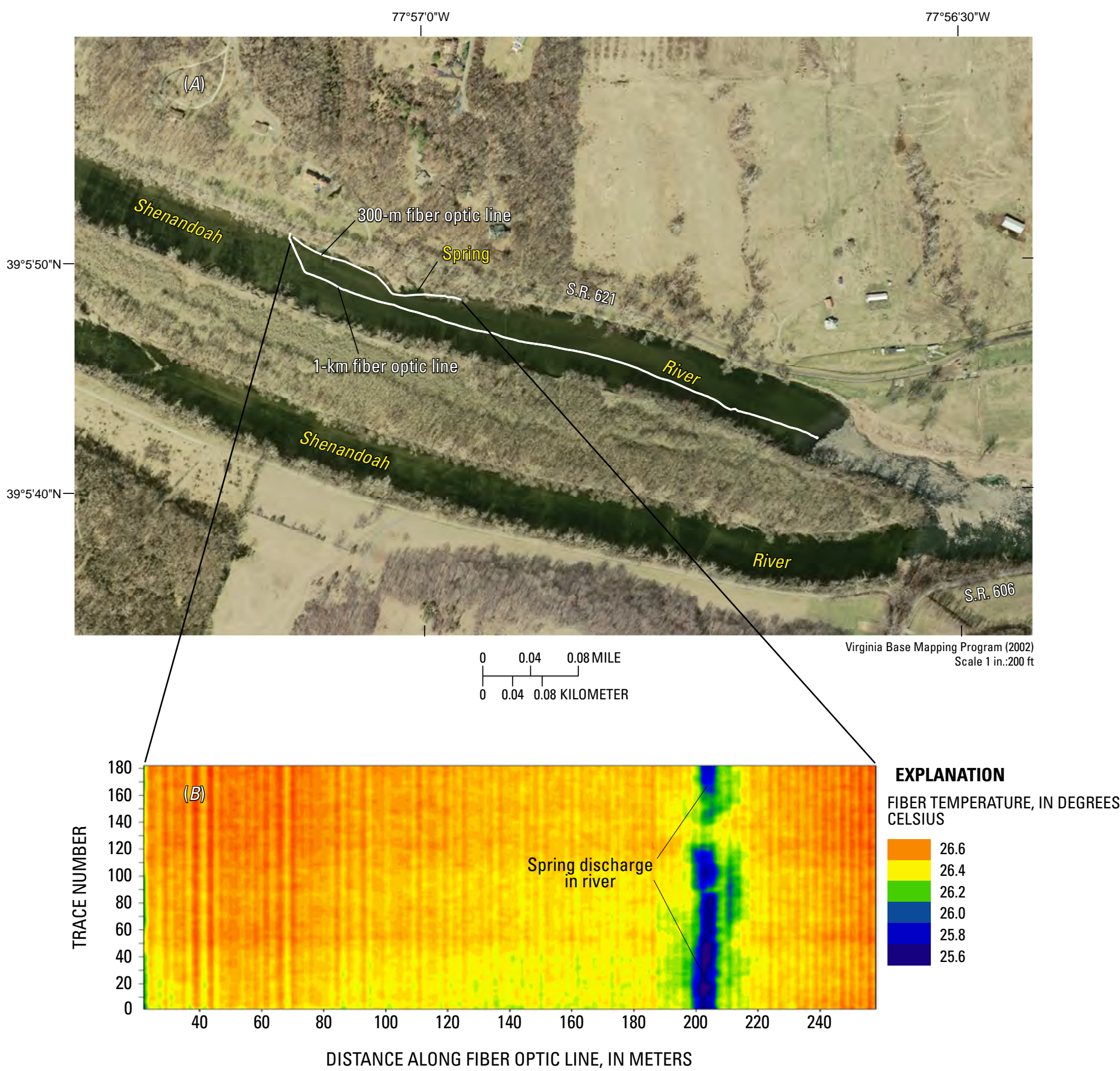

Figure 26. (A) Aerial photograph showing location of U.S. Geological Survey's Groundwater Resources Program fiber-optic distributed temperature sensing evaluation project site and $(B)$ two-dimensional display of temperature data showing thermal anomaly, Shenandoah River, Clarke County, Virginia. Data collected with 300-meter fiber, August 10, 2006, 12:10:28 to 15:10:36. Trace interval is 59 seconds. Modified from Lane and others (2008). 


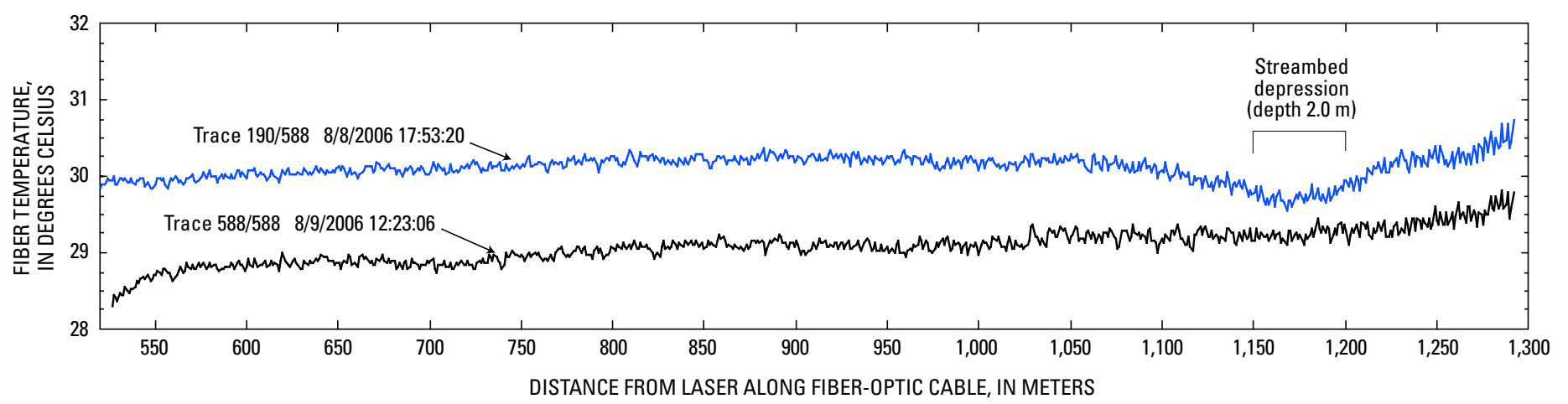

Figure 27. Fiber-optic distributed temperature sensing data showing thermal anomaly associated with streambed depression in Shenandoah River, Clarke County, Virginia.

\section{Apparent Age of Groundwater}

Groundwater apparent ages were estimated by a multiple tracer approach whereby the environmental tracers-chlorofluorocarbons (CFCs), sulfur hexafluoride $\left(\mathrm{SF}_{6}\right)$, and tritium/ helium-3 $\left({ }^{3} \mathrm{H} /{ }^{3} \mathrm{He}\right)$ — are used to date young waters (less than 60 years). A total of 15 springs located in the Great Valley section of Clarke County were sampled during the summer months of 2003-2005 (fig. 28). Timing of the sampling coincided with the period of the year when spring flows and water levels are low; therefore, estimates of apparent groundwater ages should represent the oldest ages of the young waters in the flow systems. Analytical data are presented in appendixes 5-13 at end of the report. Detailed explanation of the sampling and analytical methods is provided in Nelms and Harlow (2003).

Groundwater dating with CFCs (Busenberg and Plummer, 1992) is based on Henry's law of solubility, which is a function of the temperature during recharge and salinity of the groundwater. Concentrations of dissolved nitrogen $\left(\mathrm{N}_{2}\right)$ and argon (Ar) were used to estimate recharge temperatures and also excess air in groundwater, which is attributed to entrainment of air during recharge (Heaton, 1981; Heaton and Vogel, 1981; Heaton and others, 1983; Busenberg and others, 1993). Salinity corrections are not necessary for waters as dilute as those from the springs sampled in Clarke County (Plummer and Busenberg, 2000). The apparent CFC age of the water sample was determined by comparing the calculated partial pressures of CFCs in solubility equilibrium with the sample to the historical atmospheric CFC concentrations in North American air (fig. 29). This apparent age estimate assumes that the tracer (the CFC compound) is transported as a plug through the aquifer with no dispersive mixing in the direction of flow (Busenberg and Plummer, 1992). The CFC data, however, can provide an indication of whether the sample represents a binary mixture of old (which is often assumed to be pre-CFC) and young waters for which the relative proportions can be estimated. Sorption of CFCs to sediments and organic matter and biodegradation of the CFCs can decrease the concentrations of CFCs in groundwater. This decrease in concentration results in the apparent age determined from measured concentrations of one CFC appearing to be older than the ages determined from the other CFCs (Plummer and Busenberg, 2000). Contamination of the CFCs, in terms of dating methodology, is frequently detected and indicates that sources other than the atmosphere, such as sewage effluent, have introduced CFCs into the groundwater system. The use of other tracers aids in the age determinations and in the assessment of degradation and contamination of the CFCs.

The $\mathrm{SF}_{6}$ dating method (Busenberg and Plummer, 2000) is similar to the CFC dating method (fig. 29). Unlike CFCs, $\mathrm{SF}_{6}$ in groundwater can be derived from anthropogenic and terrigenic sources. $\mathrm{SF}_{6}$ is generally not affected by sorption and biodegradation processes, but it can be affected by excess air in groundwater. Groundwater in areas where the flux of terrigenic $\mathrm{SF}_{6}$ is high cannot be dated by the $\mathrm{SF}_{6}$ method.

Tritium $\left({ }^{3} \mathrm{H}\right)$ is the radioactive isotope of hydrogen with a half-life of 12.43 years (International Atomic Energy Agency, 1981) and has been used as an indicator of groundwater recharge since 1952 (Clark and Fritz, 1997). Tritium is produced naturally in the atmosphere by cosmic ray spallation, but the principal source from about 1952 to 1963 has been the atmospheric testing of thermonuclear weapons (fig. 29). The ${ }^{3} \mathrm{H} /{ }^{3} \mathrm{He}$ method is based on the radioactive decay of ${ }^{3} \mathrm{H}$ to helium-3 $\left({ }^{3} \mathrm{He}\right)$ such that the helium isotope mass balance is used to determine the amount of tritiogenic ${ }^{3} \mathrm{He}\left({ }^{3} \mathrm{He}_{\text {trit }}\right)$ derived from ${ }^{3} \mathrm{H}$ (Schlosser and others, 1988, 1989). If the ${ }^{3} \mathrm{He}_{\text {trit }}$ is confined in the aquifer, apparent ${ }^{3} \mathrm{H} /{ }^{3} \mathrm{He}$ ages of the water samples $(\tau)$ can be calculated from the following formula from Schlosser and others (1988, 1989):

$$
\tau=T_{1 / 2} / \ln 2 \times\left[1+\frac{\left[{ }^{3} H e_{\text {trit }}\right]}{\left[{ }^{3} H\right]}\right]
$$

where $T_{1 / 2}$ is the half-life of tritium. Neon (Ne) concentrations are used to correct ${ }^{3} \mathrm{He}_{\text {trit }}$ for samples that contain terrigenic helium from crustal and mantle sources such as metamorphic rocks. 


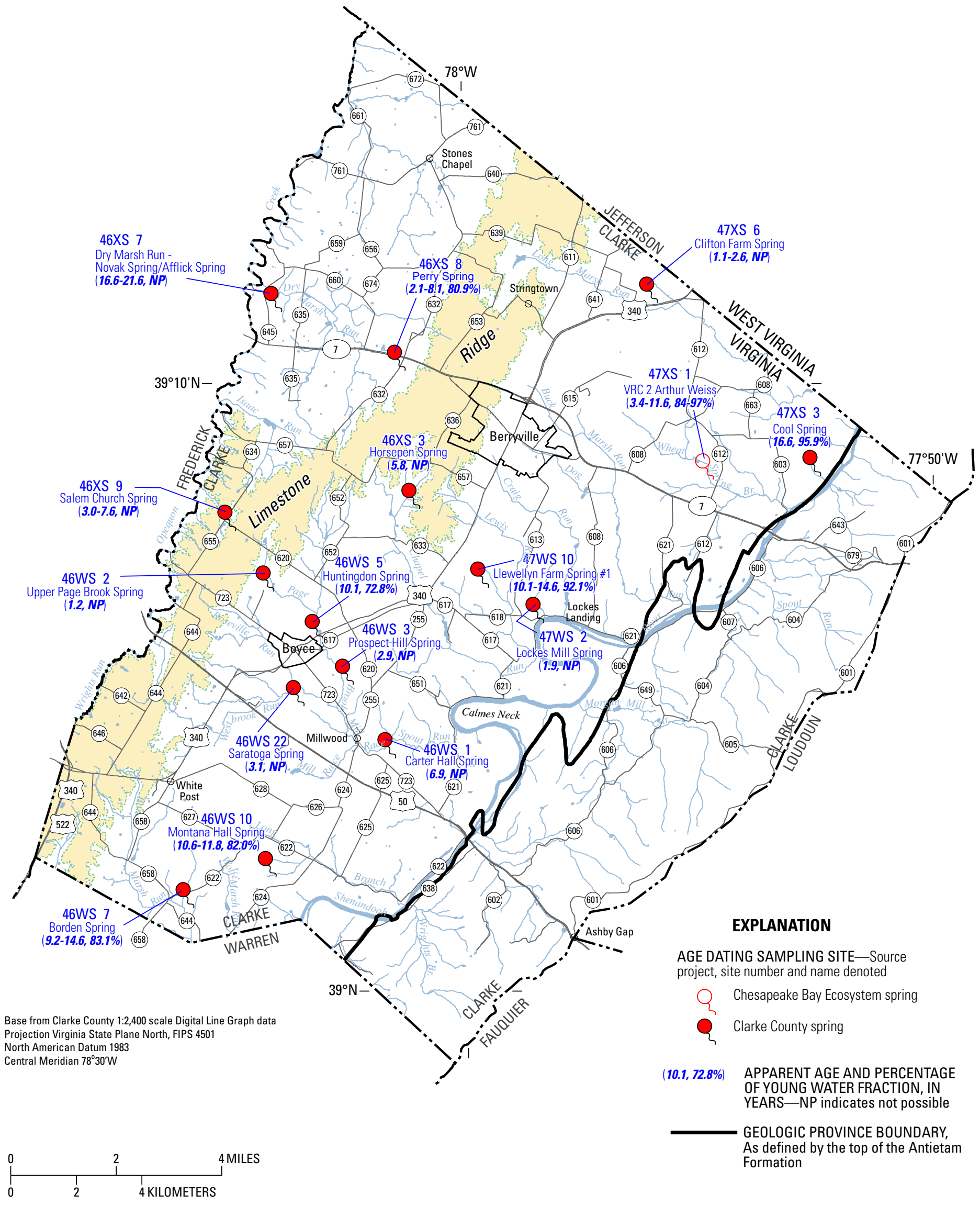

Figure 28. Apparent age and percentage of young water fraction for sampling sites in Clarke County, Virginia. 


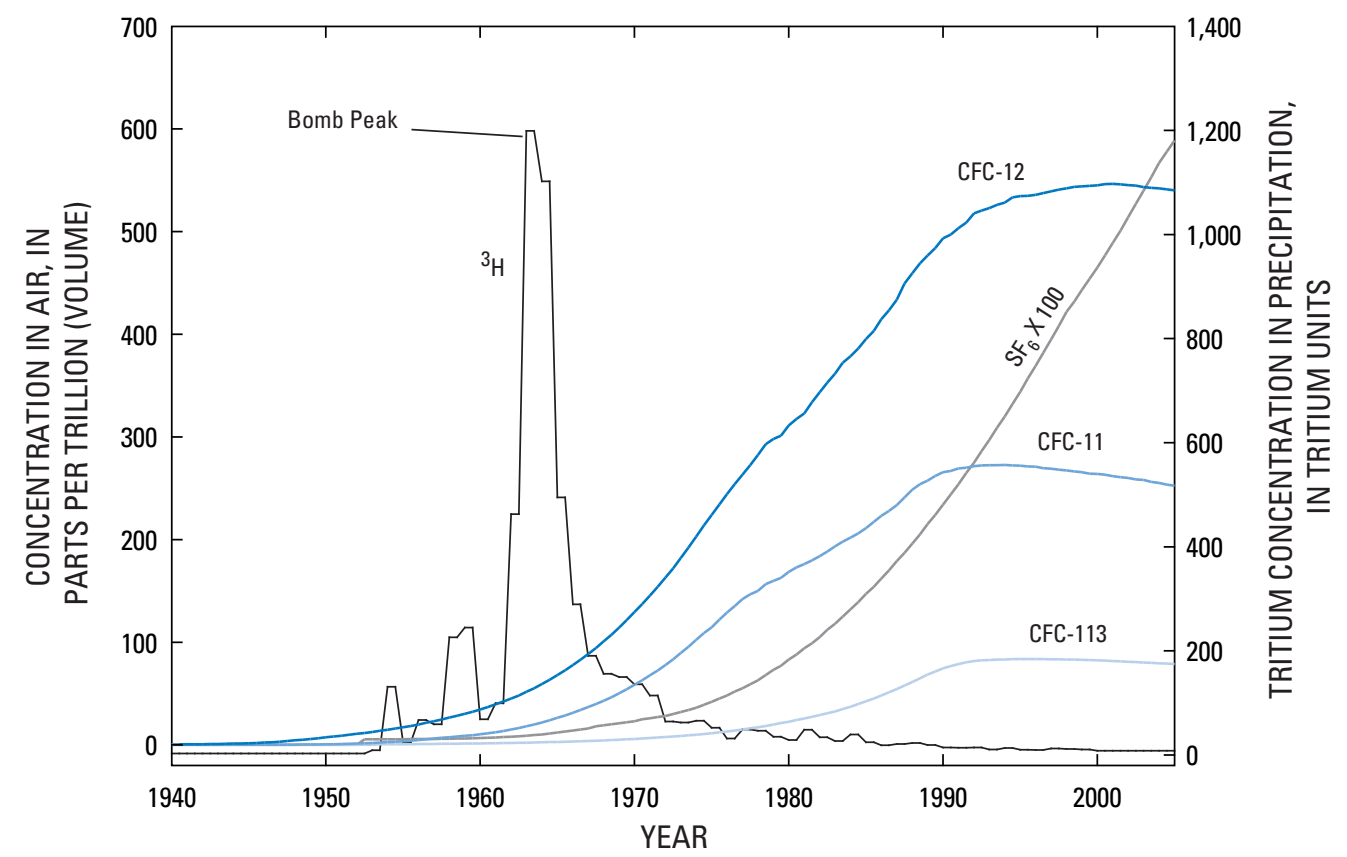

Figure 29. Atmospheric mixing ratios of chlorofluorocarbon-11 (CFC-11), chlorofluorocarbon-12 (CFC-12), chlorofluorocarbon-113 (CFC-113), and sulfur hexafluoride ( $\left.\mathrm{SF}_{6}\right)$ for North American air and estimated monthly concentration of tritium $\left({ }^{3} \mathrm{H}\right)$ in precipitation for Virginia. Tritium data derived from estimation technique of Michel (1989) and are not corrected for radioactive decay. Modified from Plummer and Busenberg (2000).

Determination of final apparent age estimates is based on the comparison of the estimates from the different tracers and whether the sample indicates piston flow or binary mixtures. The final apparent age estimates ranged from 1.1 to 21.6 years (table 3). Nearly half of the springs contained some fraction of the waters with apparent ages that were less than 5 years. Of the remaining springs, 75 percent contained waters with apparent ages greater than 10 years. Because of contamination (in terms of age determinations) of the CFCs and year of recharge, the percentage of the young fraction in some binary mixtures could not be determined. For the springs in which determination of the young fraction was possible, the young fraction ranged from approximately 73 to 96 percent. These high percentages indicate that a majority of the water discharging from the springs is young and is close to being piston flow, which would have a young fraction of 100 percent. In fact, spring 46XS 7 on Dry Marsh Run (fig. 28) indicates piston flow with apparent ages that ranged from 16.6 to 21.6 years. Water clarity even during stormflows and the presence of watercress at gaging station 01616100 , which is approximately $1,000 \mathrm{ft}$ downstream, indicate that streamflow is dominated by spring discharge. The relatively old piston-flow ages suggest relatively long residence times, which may explain the continuous flowing conditions present at this gage even during periods of prolonged drought conditions.

A review of apparent ages estimated for spring 47XS 1 (VRC 2 Arthur Weiss) (fig. 28) from three sampling events conducted in September and November 1996 and August 1997 provide insight into temporal changes in the distribution of apparent ages and mixing fractions under different hydrologic conditions (Focazio and others, 1998; Lindsey and others, 2003). Apparent ${ }^{3} \mathrm{H} /{ }^{3} \mathrm{He}$ ages increased from 3.4 to 8.8 years for the 1996 and 1997 samples, respectively, and the apparent CFC ages increased from 6.7 to 11.6 years during the same period. The percentage of the young fraction in the binary mixture decreased from 94 to 87 percent between 1996 and 1997. This finding indicates that as water levels decrease the amount of young water discharging from springs decreases. Therefore, under different hydrologic conditions, temporal changes in water-quality trends and flow rates determined by dye-tracer studies would be expected to occur.

Young apparent ages and binary mixtures generally are present at springs in the upper reaches of the basins, and the older ages are present in the lower reaches. This distribution and temporal changes of apparent ages and mixing fractions are consistent with the conceptual idea of a system that is topographically driven in which local flow systems with young waters are superimposed on the regional flow system with older waters. The height of hydraulic head in the upgradient parts of a basin is primarily controlled by the outlets (springs) of the groundwater flow systems. In some situations, the hydraulic head is higher than land surface, and groundwater will overflow along joints, especially along fold hinges or faults. This overflow does not represent convergence of flow lines, but simply is the result of pressure relief along partings in the bedrock in response to the backup of water caused by the "bottlenecks" created by the flow system outlets (generally springs). To some degree, during periods of overflow, these 


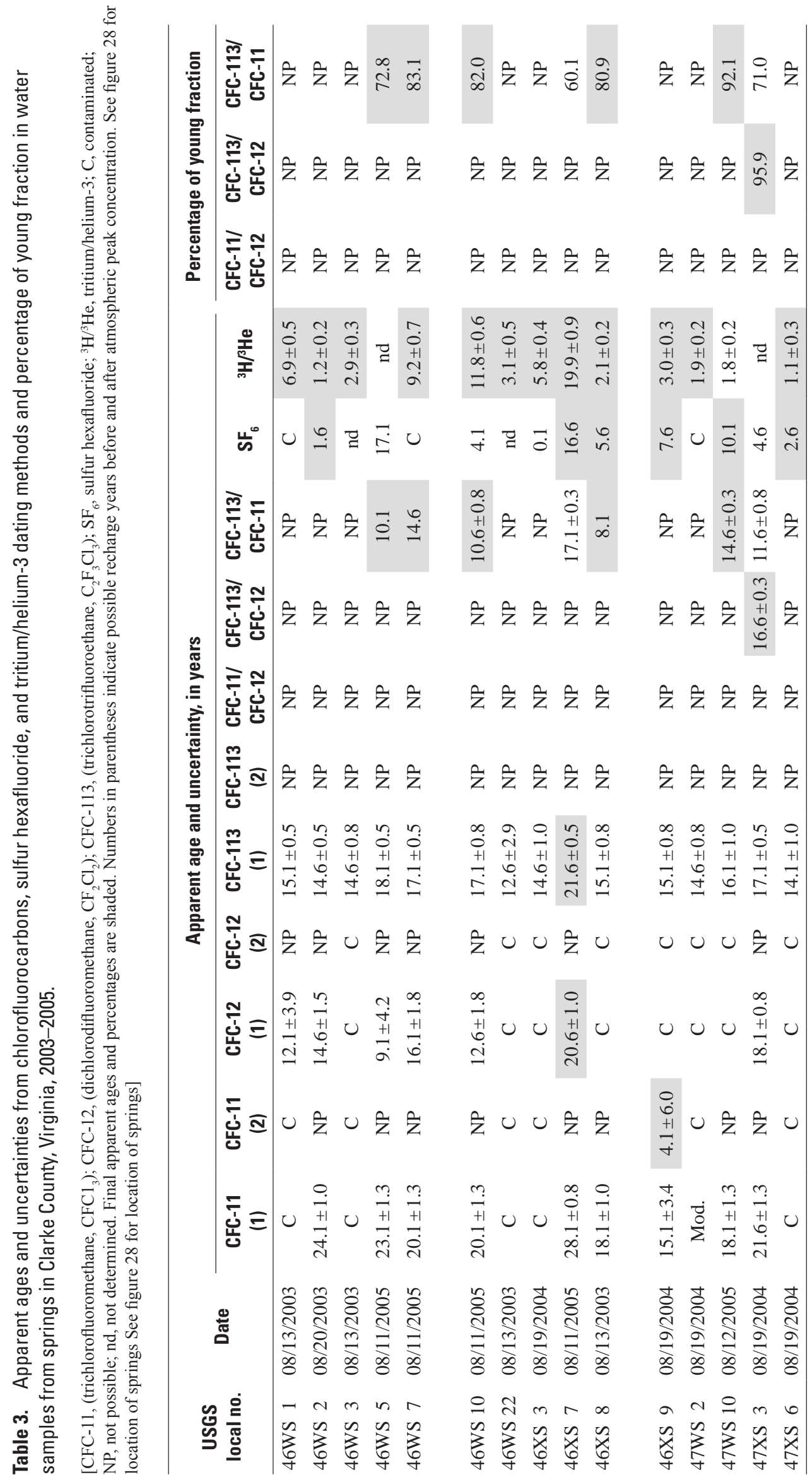


aquifer systems could be considered to be under semiconfined to confined (artesian) conditions.

Detailed groundwater dating of springs has been conducted in Blue Ridge settings similar to those located in Clarke County. Plummer and others (2001) determined that apparent ${ }^{3} \mathrm{H} /{ }^{3} \mathrm{He}$ ages for springs in Shenandoah National Park predominantly ranged between 0 and 3 years. Large precipitation events caused specific conductance and temperature to increase in these springs within a few hours of the event and then decrease to values below pre-storm base-flow values. Plummer and others (2001) also determined that mobile atmospheric constituents have flushing rates through groundwater to streams that average less than 3 years at base-flow conditions. A similar range of apparent ages for springs located in the Blue Ridge of Warren County, VA, have been estimated (D.L. Nelms, U.S. Geological Survey, written commun., 2009). Several springs sampled in Warren County, however, had apparent ages between 10 and 20 years. Both of these investigations illustrate the close relation between spring flow and precipitation in the Blue Ridge and indicate that transport of contaminants from the surface to outlets such as springs and streams can be rapid in the Blue Ridge.

\section{Revised Conceptual Model of Groundwater Flow}

Geologic sections generally are constructed normal to the strike of the rocks in order to show the overall geologic structure. Conceptually, a majority of the groundwater flow in the Great Valley is normal to these sections or along strike and cannot be depicted in figure 2. A revised conceptual hydrogeologic section that parallels the strike is shown in figure 30 . Land surface depicted in figure 30 is the intersection of the strike-parallel thrust and cross-strike faults with the surface. Regional groundwater flow moves from the elevated areas along the fault planes and bedding-plane partings until it is intercepted by a stream, spring, or cross-strike fault. McCoy and others (2005a,b) and Kozar and others (2007) noted the importance that cross-strike faults have on hydraulic properties, well yields, and flow in the neighboring counties of WV. Regional flow continues along the cross-strike fault until it either is intercepted by another strike-parallel fault or eventually discharges to a base-level spring. Superimposed on the regional flow is local flow that generally follows a shorter path to intermittent streams and springs. Generally, groundwater is under unconfined or water-table conditions. During wet periods, the amount of water entering the system can exceed the amount flowing out, which causes hydraulic pressures to increase and groundwater to be become either semiconfined or possibly confined. Faults, bedding-plane partings, and joints can allow these pressures to dissipate as overflow on the land surface, which is similar to an artesian flowing well scenario. These overflow areas in the Great Valley section, which are locally referred to as "wet weather springs," probably do not represent convergence of flow lines, but simply represent pressure release from the flow system. These overflow areas frequently are present along the axes of folds.
The conceptualization shown in figure 30 also applies to other partings in the rocks, such as bedding planes, and joints (fractures), where the direction of groundwater flow would be aligned to the dominant orientation of these features. Faultbounded areas may act as individual flow cells or blocks that route water from elevated flow cells to downgradient cells (Allen and Michel, 1999). Local, fairly rapid flow along dissolution features may not follow a regional path if karstification has obliterated the geologic structure. Topography is the driving force behind groundwater flow, and geologic structures provide the pathways that directionally control this flow.

In the Blue Ridge, topography controls groundwater gradients, and the water-table surface closely mimics land surface (fig. 31). The high density of streams in the Blue Ridge is characteristic of areas underlain by low permeability rock. The porous nature of the regolith material (overburden) and sharp contrast in permeability with the underlying bedrock coupled with the stream density and steep terrain are more conducive for the development of local flow systems. Wright (1990) stated that subsurface stormflow through the porous overburden moves rapidly to streams and springs in the Blue Ridge because of the steep gradients. Although the terrain is steep, overland flow is believed to be a lesser component of the total runoff than subsurface stormflow (Whipkey, 1965). The presence of local flow systems developed in the unconsolidated material overlying the bedrock aquifers in the riparian areas of the Blue Ridge has been suggested (D.L. Nelms, U.S. Geological Survey, written commun., 2009). When determining the locations of potential contaminant sources in the future, it will be important to consider subsurface stormflow, especially in areas near stream valleys filled with alluvial and colluvial deposits.

Flow in the bedrock of the Blue Ridge is controlled primarily by the irregular fracture network and steep terrain (Wright, 1990). Local flow systems may be controlled by stress-relief fracturing; however, bedding plane partings in the siliciclastic rocks and partings between basalt flows in the Catoctin Formation may facilitate more of a subregional- to regional-type flow. Southworth (1990) proposed that water recharged on the western slopes of the mountains of the Blue Ridge flows down-dip and eventually discharges in springs and valleys on the eastern sides of the mountains (fig. 31).

Conceptualization of the groundwater flow system in the siliciclastic rocks on the western edge of the county, underlain by the Martinsburg Formation, is more similar to that of the Blue Ridge than of the carbonate rocks of the Great Valley. Although the Martinsburg terrain is less steep and lower in altitude than the terrain of the Blue Ridge, local flow systems probably are dominant as evidenced by the high density of streams. However, subsurface stormflow is probably a minor factor because of the lack of regolith material overlying the Martinsburg Formation (Hack, 1965) and less steep terrain. Evapotranspiration and, to a lesser extent, surface runoff may be greater than in the other areas of the county because of the low permeability of the rock and the absence of regolith material. Springs seldom form in areas underlain by the Martinsburg, whereas seeps are much more common. 

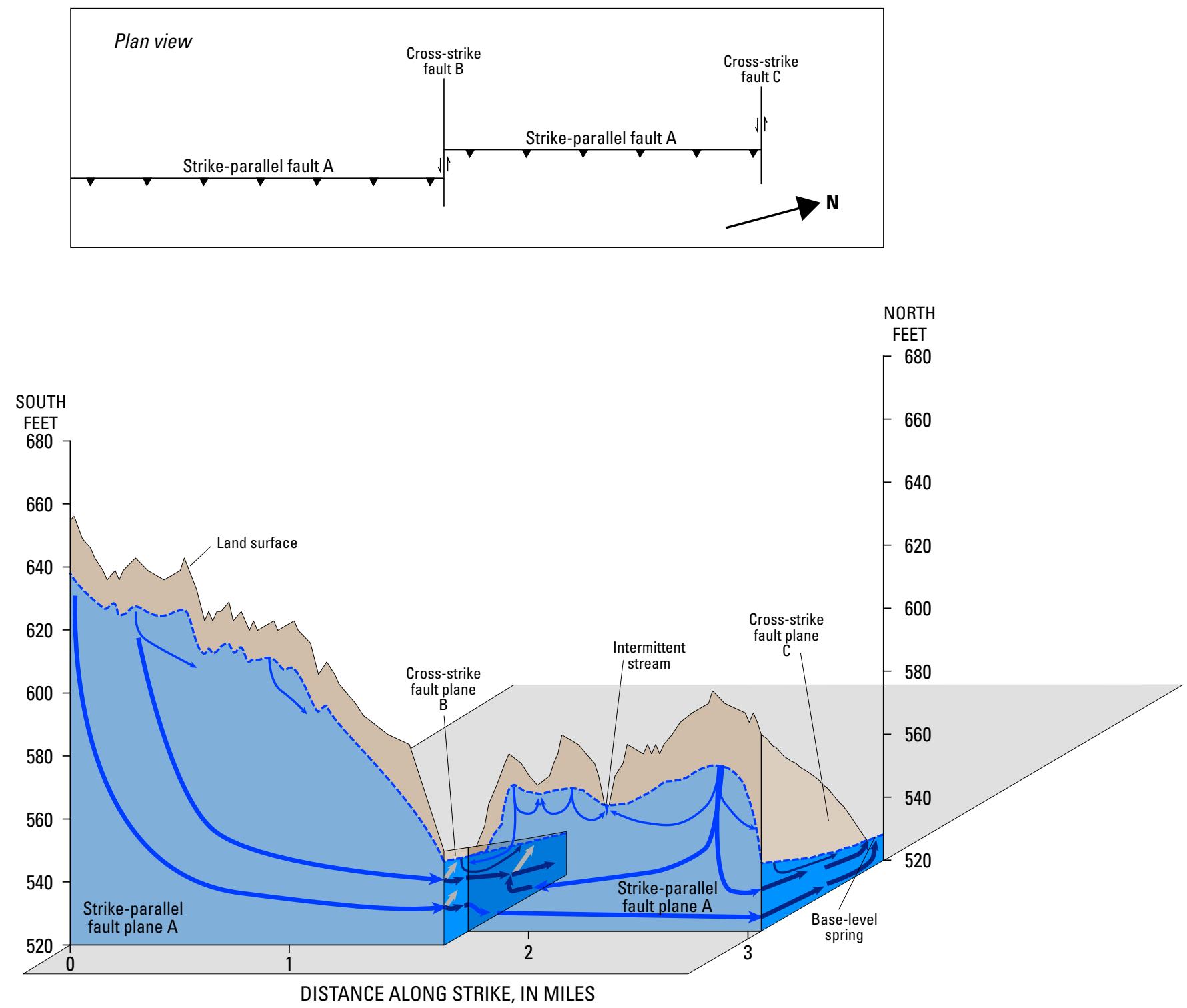

EXPLANATION

STRIKE-PARALLEL FAULT PLANE

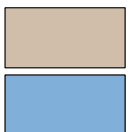

Unsaturated zone

Saturated zone

Local flow along fault plane

Regional flow along fault plane
CROSS-STRIKE FAULT PLANE

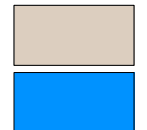

Unsaturated zone

Saturated zone

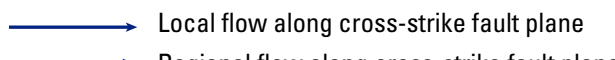

Regional flow along cross-strike fault plane

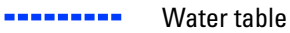

Pressure-relief flow during periods of high water levels

Figure 30. Generalized conceptual hydrogeologic longitudinal section of the flow system in the Valley and Ridge Physiographic Province in Clarke County, Virginia, showing strike-parallel and cross-strike flow along faults. View is of the upper footwall surfaces of the strike-parallel faults. Strike-parallel flow along bedding follows similar flowpaths. 


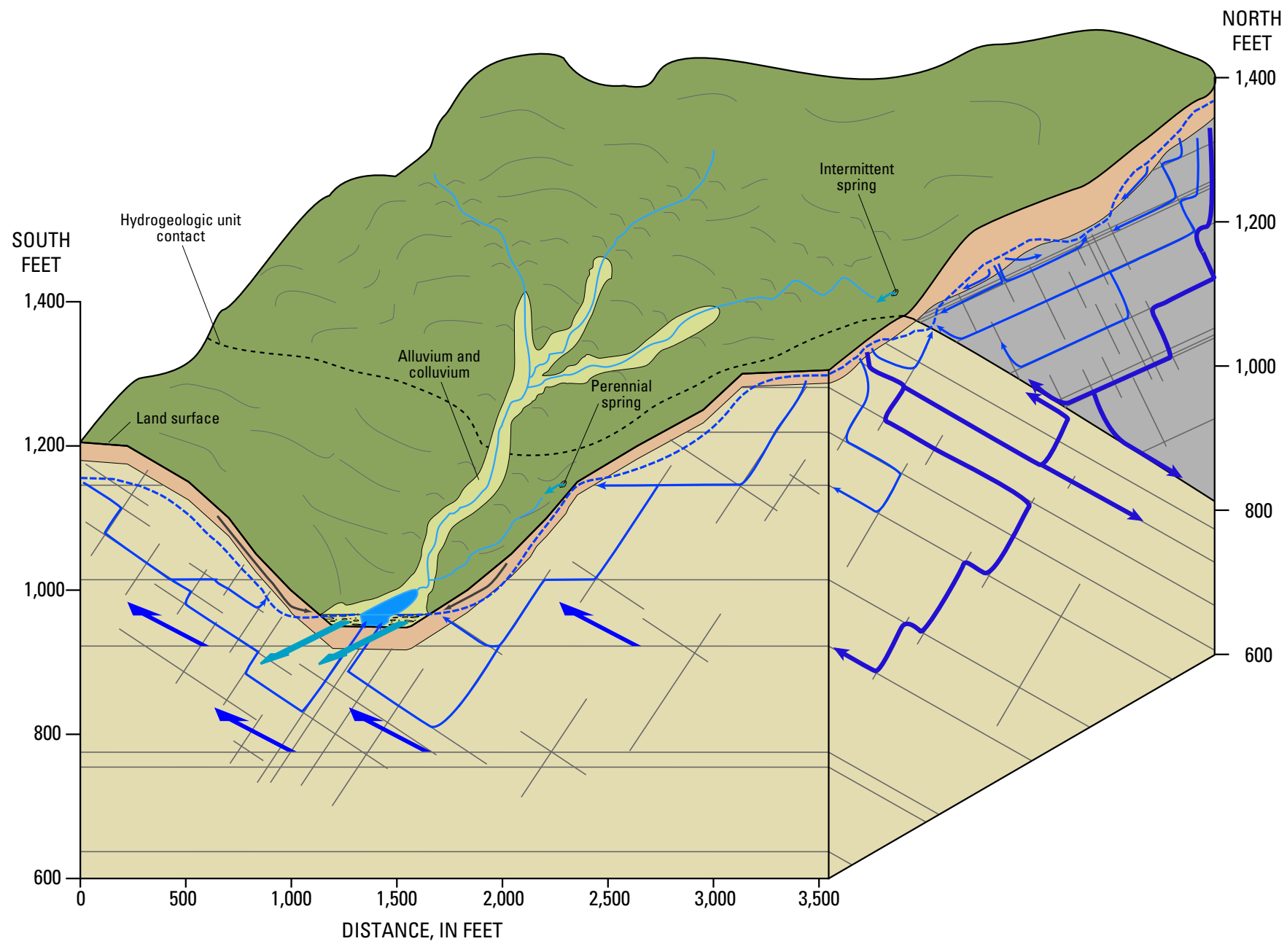

EXPLANATION
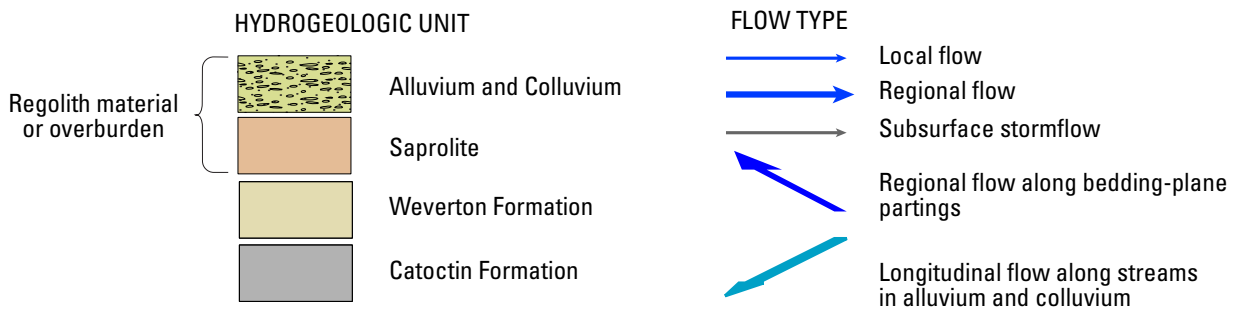

WATER TABLE

BEDDING PLANE PARTINGS AND JOINTS

Figure 31. Generalized conceptual hydrogeologic longitudinal section of the flow system in the Blue Ridge Physiographic Province in Clarke County, Virginia. 


\section{Groundwater Availability}

The prolonged drought between 1999 and 2002 caused concern about current and future demands on the county's groundwater resources. In order to address these concerns, various components related to groundwater availability were determined during this investigation. Effective recharge rates to the groundwater system were estimated by a hydrograph separation technique that separates streamflow into baseflow (groundwater discharge) and surface-runoff components (table 4). Additional rates of effective recharge for the groundwater areas were estimated by a regression equation developed by Yager and others (2008). Annual water budgets were developed for two basins (Dry Marsh and Spout Runs) in the county for the years 2001-2007. These water budgets include precipitation, mean annual streamflow, and mean annual base flow, ET, changes in groundwater storage (from water-level data), estimates of specific yield, and water withdrawal data (table 5).

\section{Effective Recharge}

Effective recharge is the part of precipitation that percolates to the water table and recharges the groundwater system, but does not represent the total recharge to a basin. Total recharge has two components: (1) effective recharge, and (2) riparian evapotranspiration (RET). RET is the quantity of water consumed by evaporation and transpiration by plants in riparian zones. Rutledge and Mesko (1996) reported that estimated values of $R E T$ ranged from 1 to $2 \mathrm{in} / \mathrm{yr}$ in the Appalachian Valley and Ridge from Alabama to New Jersey. Recharge occurs throughout a basin, but rates generally lessen towards discharge areas. Sinkholes in the Great Valley section and alluvium and colluvium in stream valleys of the Blue Ridge, however, can allow for substantial and rapid recharge. The amount of recharge depends on many factors, including antecedent soil-moisture conditions, the timing, duration, and intensity of precipitation, depth to the water table, and soil and bedrock characteristics (Harlow and others, 2005).

PART, a streamflow partitioning program (Rutledge, 1993), uses a hydrograph-separation technique that separates streamflow into its base-flow (groundwater discharge) and surface-runoff components. Effective recharge is equivalent to mean base flow because groundwater discharge over a long period of time approximately equals groundwater recharge (Richardson, 1982). Nelms and others (1997) used PART to estimate a median effective recharge of $8.4 \mathrm{in} / \mathrm{yr}$ from 73 basins and $11.1 \mathrm{in} / \mathrm{yr}$ in 46 basins in the northern Valley and Ridge and Blue Ridge of Virginia, respectively. PART was applied to hydrographs from two unregulated streams in the county-Dry Marsh and Spout Runs (table 4). PART assumes that the surface-water drainage basin and the recharge area coincide. Harlow and others (2005) noted that the validity of this assumption is uncertain. Groundwater flow beneath surface-water divides is well documented by dye-tracer studies in karst areas (Jones, 1987; Wil Orndorff, Virginia Department of Conservation and Recreation, oral commun., 2005). Regardless, the PART method provides a conservative estimate of effective recharge.

Streamflow gaging station 01616100, Dry Marsh Run near Berryville, VA, is in the northwestern corner of the county and has been in operation since August 2002. The drainage area of gaging station 01616100 is $11 \mathrm{mi}^{2}$, and is entirely within the Dry Marsh Run groundwater area (figs. 15, 24). The station is approximately $870 \mathrm{ft}$ upstream from the confluence with Opequon Creek and on the contact between the New Market Limestone and Martinsburg Formation (D.J. Weary, U.S. Geological Survey, written commun., 2008). Nearly 99 percent of the drainage area above this station is underlain by carbonate bedrock. To estimate annual effective recharge rates during the peak of the drought before the gage was installed, a linear regression equation was developed between effective recharge rates for gaging station 01616100 and those for streamflow gaging station 01614830, Opequon Creek at Route 11 near Stephens City, VA (fig. 15), between 2003 and 2007. Estimates of effective groundwater recharge between 2001 and 2007 at the Dry Marsh Run gage ranged from 6.4 to $22.5 \mathrm{in} / \mathrm{yr}$ with an average of $11.6 \mathrm{in} / \mathrm{yr}$ (table 4). Base flow accounted for between 81 and 93 percent of mean annual streamflow and averaged 90 percent over the same period. Nelms and others (1997) correlated partial record streamflow data at gage 01616100 with continuous streamflow data and estimated an annual effective recharge rate of $15.5 \mathrm{in} / \mathrm{yr}$. A majority of the streamflow at gaging station 01616100 between 2002 and 2007 was derived from several springs along Dry Marsh Run approximately 1,000 ft upstream from gaging station 01616100 . The remainder of the upstream segments had intermittent flow that was either lost into swallet holes and estavelles or the segments were completely dry. Generally, if spring 46XS 8 had substantial flow, then the segments downstream to gage 01616100 were flowing (fig. 15). Flow upstream from gaging station 01616100 at the Route 635 crossing has been documented at times and is caused by water overflowing into Dry Marsh Run from a former marl pit, which is labeled "Shale pit" on the Stephenson 7.5-degree topographic quadrangle map.

Streamflow gaging station 01636316 , Spout Run at Route 621 near Millwood, VA, is in the southeastern part of the county and has been in operation since August 2002. The drainage area of gaging station 01636316 is $21.4 \mathrm{mi}^{2}$ and is entirely within the Spout Run groundwater area (figs. 15, 24). The station is approximately $1,900 \mathrm{ft}$ upstream from the confluence with the Shenandoah River. The entire drainage area above this station is underlain by carbonate bedrock. To estimate annual effective recharge rates during the peak of the drought before the gage was installed, a linear regression equation was developed between effective recharge rates for gage 01636316 and those for streamflow gaging station 01614830 between 2003 and 2007. Estimates of effective groundwater recharge between 2001 and 2007 ranged from 6.7 to $23.0 \mathrm{in} / \mathrm{yr}$ with an average at the Spout Run gage of 


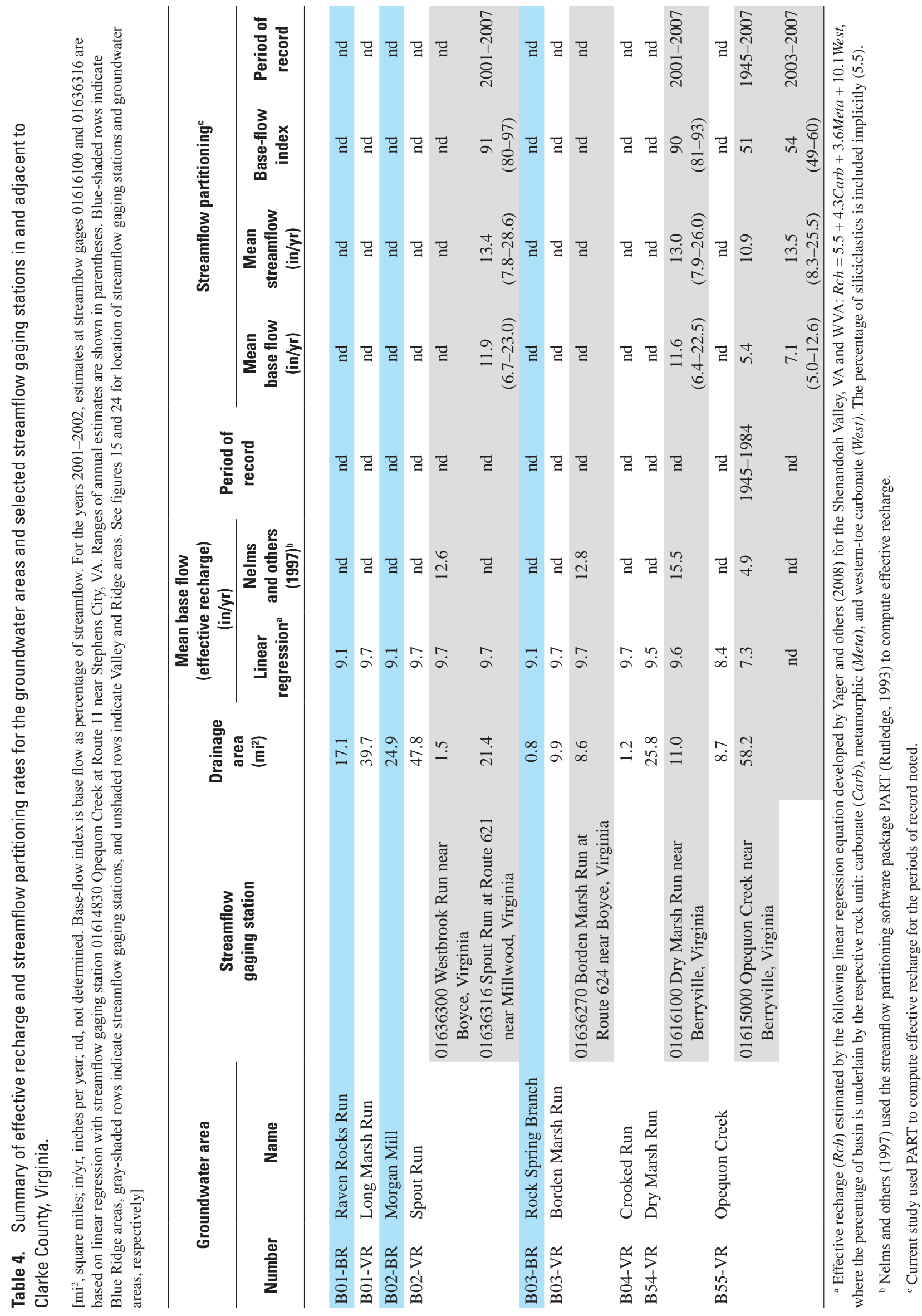


$11.9 \mathrm{in} / \mathrm{yr}$ (table 4). Base flow for gage 01636316 accounted for between 80 and 97 percent of mean annual streamflow and averaged 91 percent during the same period. Earlier sections of this report discuss the effect that springs 46WS 1, 46WS 22, and 46WS 3 have on the flow at gaging station 01636316 on Spout Run.

Although no streamflow gaging stations were established in the Blue Ridge part of the county, the same linear regression method was used for gaging stations in Warren County to estimate average annual effective recharge rates of 15.3 and $14.2 \mathrm{in} / \mathrm{yr}$ between 2001 and 2007 at streamflow gaging stations 01630700, Gooney Run near Glen Echo, VA, and 0163626650, Manassas Run at Route 645 near Front Royal, VA, respectively. Base-flow discharge composed about 70 percent of mean annual streamflow at both of these gages in Warren County. These average recharge rates should not be used in water-supply planning because these rates are strongly influenced by the alluvium and colluvium in the stream valleys and may not reflect effective recharge to the bedrock system from which domestic and public-supply wells produce water (D.L. Nelms, U.S. Geological Survey, written commun., 2009).

A large part of the drainage areas for streamflow gaging stations 01636242, Crooked Run below Route 340 at Riverton, VA, and 01615000, Opequon Creek near Berryville, VA, are underlain by the Martinsburg Formation. An effective recharge rate of $5.3 \mathrm{in} / \mathrm{yr}$ with a base-flow index of 53 percent was estimated at gaging station 01636242 between 2001 and 2007 (D.L. Nelms, U.S. Geological Survey, written commun., 2009). Effective recharge rates of 4.9, 5.4, and $7.1 \mathrm{in} / \mathrm{yr}$ were estimated for gaging station 01615000 for the periods between 1945 and 1984 (Nelms and others, 1997), 1945 and 2007, and 2003 and 2007, respectively (table 4).

In order to provide effective recharge rates for each of the groundwater areas (table 4), a linear regression model developed by Yager and others (2008) was used. The equation is based on the percentage of the basin underlain by respective rock types, uses effective recharge rates estimated by Nelms and others (1997) for 20 basins in the Shenandoah Valley, and is:

$$
\text { Rech }=5.5+4.3 \text { Carb }+3.6 \text { Meta }+10.1 \text { West },
$$

where the percentage of basin underlain by the respective rock unit [carbonate (Carb), metamorphic (Meta), and western-toe carbonate (West)] are the explanatory variables. The percentage of siliciclastic rocks is included implicitly (5.5), and the resultant effective recharge rates are in inches per year. Results from this method (table 4) indicate that effective recharge rates ranged from 9.5 to $9.7 \mathrm{in} / \mathrm{yr}$ for the groundwater areas underlain by carbonate rocks. Effective recharge rates were $9.1 \mathrm{in} / \mathrm{yr}$ in the Blue Ridge areas and $8.4 \mathrm{in} / \mathrm{yr}$ in the Opequon Creek area where a substantial proportion (31.6 percent) of the area is underlain by the Martinsburg Formation.

The areas underlain by the least permeable unit in the county, the Martinsburg Formation, have low effective recharge rates, low base-flow index, and large stream density, which probably is a function of the low permeability of the bedrock. The regression-derived recharge rate of $8.4 \mathrm{in} / \mathrm{yr}$ (table 4) for the Opequon Creek groundwater area is strongly influenced by the presence of carbonate rocks present under two-thirds of the area (table 2). Future management activities concerned with areas underlain by the Martinsburg Formation should rely on lower annual effective recharge rates that range from 4.9 to $7.3 \mathrm{in} / \mathrm{yr}$ (table 4). The range of regressionderived recharge rates in the Blue Ridge areas seems appropriate for fractured rock aquifers, whereas those determined by PART for the neighboring Warren County gages are high and probably not representative of recharge rates to the bedrock (D.L. Nelms, U.S. Geological Survey, written commun., 2009).

Base flow as a percentage of mean streamflow is known as base-flow index (BFI). The values for BFI indicate that groundwater is a major component of streamflow in the county. The high values of BFI for the Dry Marsh Run and Spout Run Basins indicate that groundwater is the dominant source of streamflow during wet and drought conditions. The values of BFI determined for the Blue Ridge streams in Warren County are slightly lower than those for carbonate basins, but values still indicate that groundwater is a large component of streamflow (D.L. Nelms, U.S. Geological Survey, written commun., 2009). Even basins underlain by the siliciclastic rock unit have BFI values that indicate that groundwater composes more than 50 percent of mean annual streamflow. The determination that groundwater is a major component of streamflow needs to be considered by any water-resources management activity in the county.

Analysis of data from the long-term water monitoring network and of effective recharge rates indicates a close correlation with current climatic conditions. A comparison of annual recharge rates at streamflow gaging stations 01616100 and 01636316 to annual precipitation is shown in figure 32 . On average, annual effective recharge is about 30 percent of the annual precipitation with a 95-percent confidence interval of about \pm 8 percent. The timing and type of precipitation, however, is critical in determining the amount of water that will actually recharge the groundwater system. The majority of groundwater recharge occurs between January and April of each year when plants are dormant and evapotranspiration is at a minimum. In 2002, the effective recharge rate of about 15 percent of annual precipitation deviated from the apparent correlation because precipitation and snowfall for the winter quarter were below normal. Conversely, years 2003 and 2004 show high recharge rates of 40 percent of annual precipitation. Precipitation, especially snowfall, was above normal for the entire calendar year of 2003 and was above normal in the early spring of 2004. Normally, water levels, spring discharges, and streamflows are highest by April of each year and progressively decline to their lowest in the early autumn. Intense rainfall associated with hurricanes, tropical storms, or thunderstorms can cause levels and flows to momentarily increase. 


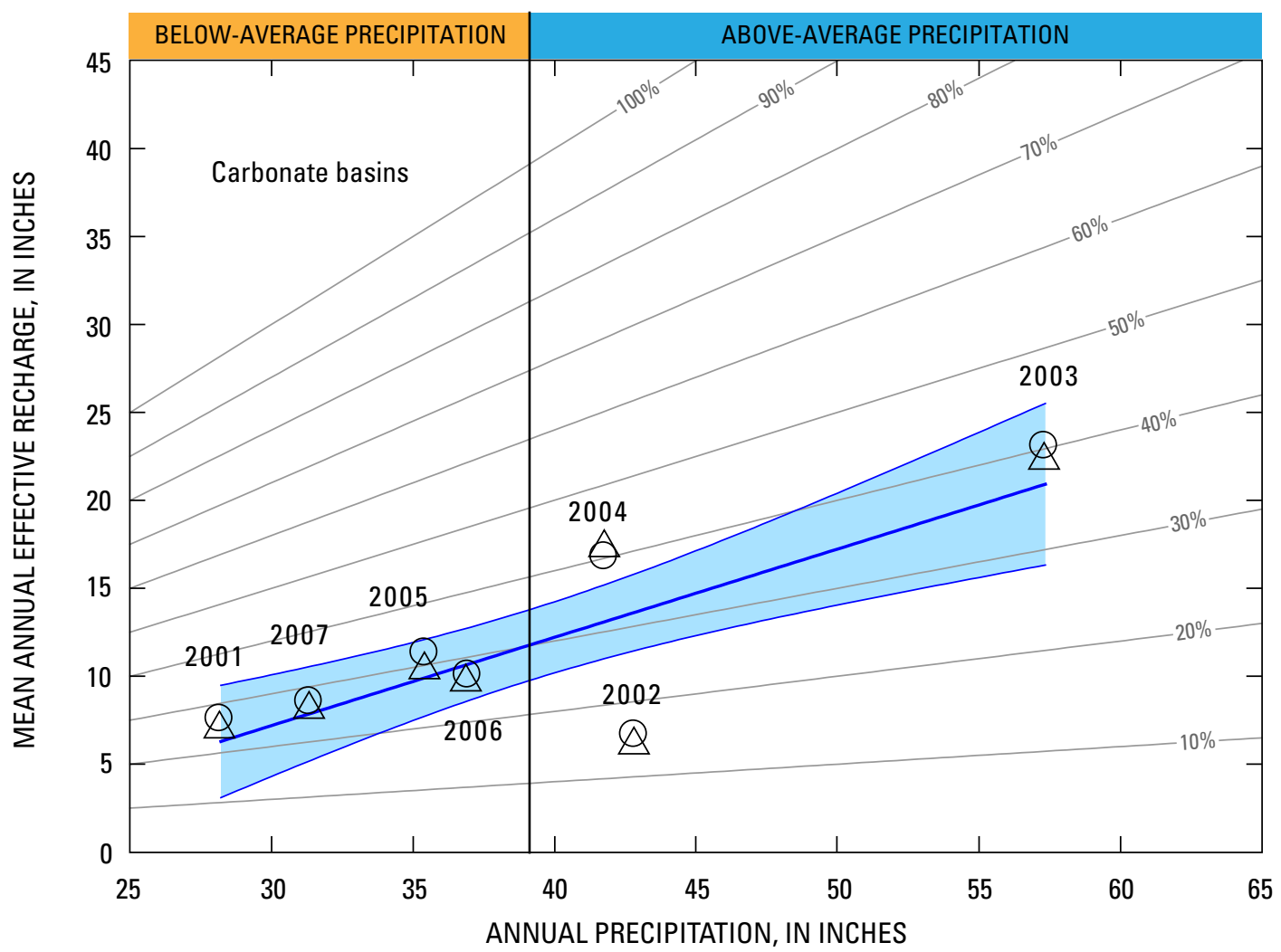

EXPLANATION

STREAMFLOW GAGING STATION

$\triangle 01616100$ Dry Marsh Run near Berryville, VA

O 01636316 Spout Run at Route 621 near Millwood, VA

2001 CALENDAR YEAR

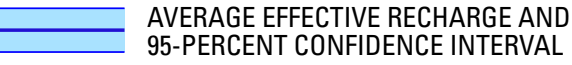

$10 \%$ - PERCENTAGE OF ANNUAL PRECIPITATION

Figure 32. Relation between annual precipitation at National Weather Service climatological station 449186 Winchester 7 SE, Virginia, and effective recharge at streamflow gaging stations 01616100 Dry Marsh Run near Berryville, Virginia, and 01636316 Spout Run at Route 621 near Millwood, Virginia. Effective recharge rates for the years 2001-2002 are estimated based on linear regression with streamflow gaging station 01614830 Opequon Creek at Route 11 near Stephens City, Virginia. Effective recharge rates for the years 2003-2007 are estimated from the streamflow partitioning software package PART (Rutledge, 1993).

\section{Water Budget}

Water budgets represent an estimate of the amount of water entering and leaving a basin plus or minus changes in storage over a specified time period (Harlow and others, 2005). Precipitation is the dominant inflow to a basin; outflows are streamflow, $E T$, and groundwater and surface-water withdrawals. All of the water-budget components are in terms of mean annual values. The water-budget equation can take many forms (Healy and others, 2007), but a simplified version that is most relevant in water-supply planning can be written as:

$$
P=E T+R O+\Delta S+W U+E R
$$

where

$$
\begin{array}{cl}
P & \text { is precipitation, in inches per year; } \\
E T & \text { is evapotranspiration, in inches per year; } \\
R O & \text { is mean surface runoff, in inches per year; } \\
\Delta S & \text { is change in groundwater storage, in inches } \\
& \text { per year; } \\
W U & \text { is water usage (withdrawals), in inches per } \\
& \text { year; and } \\
E R & \text { is effective recharge (mean base flow or } \\
& \text { groundwater discharge), in inches per year. }
\end{array}
$$

This form of the water-budget equation assumes that groundwater and surface-water divides are coincident and does not take into account underflow that may enter or leave a basin. 
Underflow in a basin in Pennsylvania that is underlain by carbonate rock has been estimated to be $2.4 \mathrm{in} / \mathrm{yr}$ (Senior and others, 1997). The terms $P, R O, \Delta S, W U$, and $E R$ are known, measured, or estimated; therefore, solution of the water-budget equation provides an estimation of ET. Harlow and others (2005) noted that the term ET also includes deviations from the assumptions of the equation, such as underflow between basins, other losses, and errors in the other terms. Average annual water budgets for calendar years 2001 and 2007 were prepared for the Dry Marsh Run and Spout Run Basins (table 5).

Annual precipitation data, which includes rainfall and snowfall, were obtained from the NWS climatological station 449186 Winchester 7 SE located to the west in Frederick County, VA. Annual precipitation ranged from 28.2 to 57.4 in. between 2001 and 2007; therefore, the dominant inflow component $(P)$ of the calculated water budgets nearly encompasses the entire range measured at station 449186. Also, these water budgets are almost equally distributed between above- and below-normal precipitation conditions (table 5). The average annual precipitation for the period 2001-2007 is equivalent to the long-term normal precipitation at station 449186; therefore, the averaged water budgets shown in table 5 can be considered as representative of normal precipitation conditions.

The $R O$ term is estimated by subtracting effective recharge (mean base flow) from mean annual streamflow. The high permeability of the rocks and low relief in the Great Valley are not conducive for surface runoff; therefore, on average, only about 3 to 4 percent of the precipitation that falls on the basins becomes runoff. $R O$ increases during above-normal conditions to between 6 and 10 percent of the precipitation (table 5). $R O$ is a small component of water budgets for basins in the Blue Ridge of Warren County (D.L. Nelms, U.S. Geological Survey, written commun., 2009).

Changes in groundwater storage $(\Delta S)$ are normally negligible in water-budget calculations in karst and fracturedrock flow systems because the specific yield of these types of systems is low. Normally, $\Delta S$ is based on changes in water levels from one year to the next at a specific time of year (for example, the month of January). The difference in the yearly high water levels was used because this indicates the maximum $\Delta S$. For the years 2001-2003, water-level changes from well 46W175 were used in both basins. For the years 20042007, the average change in water levels for 11 wells in the Dry Marsh Run Basin and 4 wells in the Spout Run Basin was used. In order to calculate $\Delta S$, the water-level changes were multiplied by 0.01 , which is the estimated specific yield of the zone of water-level fluctuation (Harlow and others, 2005). Although water-level fluctuations are large in the county, changes in groundwater storage on average are small (table 5).

In both of the basins, domestic withdrawal of groundwater is the primary use of water and is assumed to be consumptive. In order to calculate total withdrawal, the number of addressed buildings in the basins was determined by intersecting the basin boundaries with a shapefile of buildings from the county's geographic information system. The number of addressed buildings was multiplied by the average family size of 2.48 people per household, and the product was multiplied by 75 gallons per day, which is the per person water-use estimate for Virginia (Hutson and others, 2004). The total daily domestic water usage of 0.1 and 0.2 million gallons (Mgal) for Dry Marsh and Spout Run, respectively, was then converted to a yearly estimate and normalized by area of each respective basin (table 5). The total daily domestic water usage appears to be substantial; but in terms of the overall water budget, $W U$ on average is only a small percentage ( 0.5 percent). The assumption, however, that $W U$ is consumptive is not completely valid because the predominant method of sewage disposal in the county is by onsite septic wastewater-treatment systems. The siting requirements in the county's septic ordinance help to reduce runoff and evapotranspiration of septic system outflows. Paul (2007) showed that only 1 percent of septic outflows was lost to evapotranspiration from an arid area with limited vegetative cover in Colorado. In metropoli$\tan$ Atlanta, GA, base flow increased for basins with a high density of septic systems (greater than 200 systems per square mile) in response to septic outflow of municipal surface-water supplies (Landers and Ankcorn, 2008). Keyworth (2009) estimated that 85 percent of the wastewater discharged to septic systems is returned to the groundwater system. In some areas of the Spout Run Basin, water withdrawn from spring 46WS 3 (Prospect Hill) is returned to the basin either by septic system outflows or effluent discharge to Roseville Run from the sewage treatment plant located in Boyce, VA (fig. 15).

Groundwater storage in the type of aquifer systems in Clarke County is minimal; therefore, the amount of water that recharges the groundwater system $(E R)$ each year is critical. For the period between 2001 and 2007, about 30 percent of the precipitation that fell in the Dry Marsh Run and Spout Run Basins reached the water table as recharge (table 5; fig. 32). Analysis of data collected by the long-term water monitoring network indicates that these systems are extremely vulnerable to climatic conditions. Successive years of below-average $E R$ cause declines in water levels, spring discharges, and streamflows; however, these systems can recover quickly as $E R$ increases. $E R$ tends to increase as precipitation increases, but lack of precipitation, especially snow, during the critical recharge period can have a substantial effect on the amount of $E R$ (fig. 32). Evaluation of the effect that future development will have on the water resources often assumes an $E R$ rate of 50 percent of normal. Data in table 5 indicate that this assumption seems reasonable and that an even lower percentage could help plan for droughts in the future that may be more severe than the drought between 1999 and 2002 (fig. 32). Future water-supply planners also may consider the percentage of water withdrawals versus $E R$ (table 5).

The estimation of $E T$ is one of the shortcomings of any water-budget calculation. For the water budgets determined for the Dry Marsh Run and Spout Run Basins, ET is estimated by solution of equation 3 and also includes underflow, other losses, and errors (Harlow and others, 2005). The declines in water levels, spring discharges, and streamflows during the 
Table 5. Summary of annual water budget components for the Dry Marsh Run and Spout Run Basins in Clarke County, Virginia, 2001-2007.

$\left[\mathrm{mi}^{2}\right.$, square miles; in/yr, inches per year; DA, drainage area; $P$, precipitation at National Weather Service station 449186 Winchester 7 SE located in Frederick County, VA; $E T$, evapotranspiration; $\Delta S$, change in groundwater storage; Bldgs, number of addressed buildings in the watershed; $W U$, water usage; $S F$, mean streamflow; $R O$, surface runoff; $E R$, effective recharge estimated from streamflow partitioning program PART (Rutledge, 1993). Percentages of annual precipitation are shown in parentheses. Blue shaded rows indicate years with above-average precipitation, and unshaded rows indicate years with below-average precipitation. Gray shaded rows indicate average values for the period 2001-2007. See figure 15 for location of streamflow gaging stations]

\begin{tabular}{|c|c|c|c|c|c|c|c|c|c|c|c|c|c|}
\hline \multirow{2}{*}{$\begin{array}{c}\text { Station } \\
\text { no. }\end{array}$} & \multirow{2}{*}{ Station } & \multirow{2}{*}{$\begin{array}{c}\mathrm{DA} \\
\left(\mathrm{mi}^{2}\right)\end{array}$} & \multirow{2}{*}{$\begin{array}{c}\text { Calendar } \\
\text { year }^{\mathrm{a}}\end{array}$} & \multirow{2}{*}{$\begin{array}{c}\begin{array}{c}\text { Inflow } \\
\text { (in/yr) }\end{array} \\
P^{\mathrm{d}}\end{array}$} & \multicolumn{7}{|c|}{$\begin{array}{c}\text { Outflow } \\
\text { (in/yr) }\end{array}$} & \multirow{2}{*}{$\begin{array}{c}\text { Percent } \\
\text { of } \\
\text { normal } \\
\text { ER }\end{array}$} & \multirow{2}{*}{$\begin{array}{c}W U \\
\text { percent } \\
\text { of } E R\end{array}$} \\
\hline & & & & & $E T$ & $\Delta \boldsymbol{S}^{\mathbf{e}}$ & Bldgs. ${ }^{f}$ & $W U^{\mathfrak{f}}$ & $S F$ & RO & $E R$ & & \\
\hline & \multirow{5}{*}{$\begin{array}{l}\text { Dry Marsh Run } \\
\text { at Route } 645 \\
\text { near Berryville, } \\
\text { Virginia }\end{array}$} & \multirow{5}{*}{11.0} & 2002 & 42.9 & $\begin{array}{c}35.2 \\
(82.1)\end{array}$ & -0.4 & 437 & $\begin{array}{c}0.2 \\
(0.5)\end{array}$ & $\begin{array}{c}7.9 \\
(18.4)\end{array}$ & $\begin{array}{c}1.5 \\
(3.5)\end{array}$ & $\begin{array}{c}6.4 \\
(14.9)\end{array}$ & 55 & 2.4 \\
\hline & & & 2004 & 41.8 & $\begin{array}{c}23.4 \\
(56.0)\end{array}$ & -0.7 & 437 & $\begin{array}{c}0.2 \\
(0.5)\end{array}$ & $\begin{array}{c}18.6 \\
(44.5)\end{array}$ & $\begin{array}{c}1.5 \\
(3.6)\end{array}$ & $\begin{array}{c}17.1 \\
(40.9)\end{array}$ & 147 & 0.9 \\
\hline & & & 2005 & 35.5 & $\begin{array}{c}24.7 \\
(69.6)\end{array}$ & -0.4 & 437 & $\begin{array}{c}0.2 \\
(0.6)\end{array}$ & $\begin{array}{c}11.1 \\
(31.3)\end{array}$ & $\begin{array}{c}0.8 \\
(2.3)\end{array}$ & $\begin{array}{c}10.3 \\
(29.0)\end{array}$ & 89 & 1.5 \\
\hline & & & 2006 & 36.9 & $\begin{array}{c}27.2 \\
(73.7)\end{array}$ & -0.6 & 437 & $\begin{array}{c}0.2 \\
(0.5)\end{array}$ & $\begin{array}{c}10.2 \\
(27.6)\end{array}$ & $\begin{array}{c}0.7 \\
(1.9)\end{array}$ & $\begin{array}{c}9.5 \\
(25.7)\end{array}$ & 82 & 1.6 \\
\hline & & & Average & 39.1 & $\begin{array}{c}26.0 \\
(67.7)\end{array}$ & 0.1 & 437 & $\begin{array}{c}0.2 \\
(0.5)\end{array}$ & $\begin{array}{c}13.0 \\
(32.0)\end{array}$ & $\begin{array}{c}1.3 \\
(3.1)\end{array}$ & $\begin{array}{c}11.6 \\
(28.8)\end{array}$ & & 1.3 \\
\hline \multirow[t]{5}{*}{01636316} & \multirow{5}{*}{$\begin{array}{l}\text { Spout Run at Route } \\
621 \text { near Mill- } \\
\text { wood, Virginia }\end{array}$} & \multirow[t]{5}{*}{21.4} & 2001 & 28.2 & $\begin{array}{c}20.4 \\
(72.3)\end{array}$ & -0.2 & 855 & $\begin{array}{c}0.2 \\
(0.7)\end{array}$ & $\begin{array}{c}7.8 \\
(27.7)\end{array}$ & $\begin{array}{c}0.3 \\
(1.1)\end{array}$ & $\begin{array}{c}7.6 \\
(27.0)\end{array}$ & 63 & 2.1 \\
\hline & & & 2002 & 42.9 & $\begin{array}{c}35.2 \\
(82.1)\end{array}$ & -0.4 & 855 & $\begin{array}{c}0.2 \\
(0.5)\end{array}$ & $\begin{array}{c}7.9 \\
(18.4)\end{array}$ & $\begin{array}{c}1.1 \\
(2.6)\end{array}$ & $\begin{array}{c}6.7 \\
(15.6)\end{array}$ & 56 & 2.3 \\
\hline & & & 2003 & 57.4 & $\begin{array}{c}26.5 \\
(46.2)\end{array}$ & 2.1 & 855 & $\begin{array}{c}0.2 \\
(0.3)\end{array}$ & $\begin{array}{c}28.6 \\
(49.8)\end{array}$ & $\begin{array}{c}5.6 \\
(9.8)\end{array}$ & $\begin{array}{c}23.0 \\
(40.1)\end{array}$ & 193 & 0.7 \\
\hline & & & 2004 & 41.8 & $\begin{array}{c}23.7 \\
(56.7)\end{array}$ & -0.4 & 855 & $\begin{array}{c}0.2 \\
(0.5)\end{array}$ & $\begin{array}{c}18.2 \\
(43.5)\end{array}$ & $\begin{array}{c}1.6 \\
(3.8)\end{array}$ & $\begin{array}{c}16.7 \\
(40.0)\end{array}$ & 140 & 0.9 \\
\hline & & & Average & 39.1 & $\begin{array}{c}25.5 \\
(66.7) \\
\end{array}$ & 0.1 & 855 & $\begin{array}{c}0.2 \\
(0.5) \\
\end{array}$ & $\begin{array}{c}13.4 \\
(33.0)\end{array}$ & $\begin{array}{c}1.5 \\
(3.3)\end{array}$ & $\begin{array}{c}11.9 \\
(29.7)\end{array}$ & & 1.3 \\
\hline
\end{tabular}

${ }^{a}$ For the years 2001-2002, estimates are based on linear regression with streamflow gaging station 01614830 Opequon Creek at Route 11 near Stephens City, VA.

${ }^{\mathrm{b}}$ Water-budget equation is $P=E T+R O+E R+\Delta S+W U$.

c To convert inches per year to cubic feet per second, divide value by 13.5837 and then multiply by drainage area (in square miles).

${ }^{d}$ Normal annual precipitation of 39.1 inches at National Weather Service station 449186 Winchester 7 SE is based on the current normal climatological period 1971-2000.

${ }^{\mathrm{e}} \Delta S$ is based on the highest water levels recorded for the respective calendar year subtracted from the highest value for the previous year and a specific yield of 0.01 . For the calendar years 2001-2003, $\Delta S$ was calculated using water-level data from well 46W175. For the calendar years 2004-2007, $\Delta S$ was calculated by averaging the $\Delta S$ in 11 and 4 wells in the Dry Marsh and Spout Run watersheds, respectively.

${ }^{\mathrm{f}}$ Source is the buildings shapefile from the Clarke County geographic information system. WU was estimated by multiplying the number of addressed buildings by the average family size of 2.48 people per household, and the product was multiplied by 75 gallons per day, which is the per person water-use estimate for Virginia (Hutson and others, 2004). The total daily domestic water usage of 0.1 and 0.2 million gallons (Mgal) for Dry Marsh and Spout Run, respectively, was then converted to a yearly estimate and normalized by area of each respective basin. 
spring and summer months indicate that $E T$ is probably the dominant outflow component for any water budget in the area. Between 46 and 82 percent of the precipitation that fell on the two basins between 2001 and 2007 was removed by ET (table 5).

Future development could cause reductions in groundwater recharge (resulting from increases in impervious area), increased water consumption, or the transfer of water to other basins, and concomitant reductions in mean streamflow are expected in these systems where groundwater is such a major component of streamflow. Possible changes in streamflows and groundwater levels as development continues may be assessed using data collected as part of the long-term monitoring. In addition, Bredehoeft (2002) suggests that the use of groundwater models is a better means of assessing sustainable development than those based solely on effective recharge.

\section{Drought Effects}

Prior to the prolonged drought between 1999 and 2002, documentation of drought effects was constrained by the paucity of continuous data and limited knowledge of the karst and fractured-rock aquifer systems in the northern Shenandoah Valley. More than 20 wells went dry or had insufficient yield, with a majority of these located in the Dry Marsh Run groundwater area. Aerial photographs acquired in 1996 by the county and at the peak of the drought in 2002 by the Virginia Base Mapping Program assisted with the evaluation of drought effects during this period. The wet areas in the Dry Marsh Run groundwater area that are clearly visible in the 1996 photographs, when spring 46XS 8 is flowing, are completely dry in 2002 (fig. 33). In fact, the 2002 aerial photograph indicates that a majority of the stream segments in the Dry Marsh Run groundwater area were dry. During this investigation, this phenomenon was observed on numerous occasions, and the intermittent nature of the streams is directly related to the flow conditions of the springs. Similar conditions are evident along Route 620 just west of Boyce, VA (fig. 34). During wet conditions, groundwater flows along joints and bedding-plane partings, and can overflow in areas where the water table is elevated above land surface (figs. 19 and 20). The concept that over-pressurization of water along these joints and beddingplane partings in response to increased hydraulic head caused by backup of water by the limited number of outlets (springs and streams) in the immediate area is a possible explanation. During drought conditions, the hydraulic head has sufficient time to be lowered by discharge from the various outlets.

Well 46W175 has the longest continuous water-level record in the northern Shenandoah Valley of Virginia. Several daily maximum water-level records were established between 2002 and 2003. Although several quarters between 1998 and 2001 had precipitation above normal, most of the abovenormal precipitation occurred when groundwater recharge was minimal, and most of the quarterly snowfall totals were below normal (fig. 35). The overall decline in water levels closely follows the below-normal and poorly timed precipitation. Beginning in April 2002, seven successive quarters of abovenormal precipitation (with two of these quarters having abovenormal snowfall) caused water levels in well 46W175 to rise approximately $20 \mathrm{ft}$ to record daily maximum highs (fig. 35). Overall, water levels declined between 2004 and 2008 in response to below-normal precipitation, lack of snowfall, and timing of the precipitation (fig. 35). Water-level records from well 46W175 indicate that the frequency of the drought cycle is about 6 years, which is slightly less than the 10-year cycle of drought occurrence commonly observed in the mid-Atlantic area. Data from the water-level record from well 46W175 in conjunction with other data collected during this investigation indicate that the flow systems are highly susceptible to changes in climatic conditions.

Assessment of drought severity is important in understanding groundwater availability and in water-supply planning. The statistical distribution of daily water levels in well 46W175 grouped by calendar year can be one component in the assessment of drought severity (fig. 36). Normal waterlevel conditions, which are between the $25^{\text {th }}$ and $75^{\text {th }}$ percentiles for the period of 1988-2008, are shown as the grayshaded area in figure 36. For 2002, all daily water levels were below the normal range, and the majority of these water levels are the lowest ever recorded in well 46W175. The statistical distribution of water levels in the following year (2003) illustrates how quickly these systems can recover (fig. 36). Continuation of the collection of these data may allow waterresources managers to assess drought severity and to determine if conditions are in a declining period in the future.

Plots of precipitation versus annual estimates of mean streamflow, runoff, and effective recharge (base flow) can indicate drought severity and overall trends. Figure 37 shows the close relation between precipitation and the different flow characteristics for the Dry Marsh Run and Spout Run Basins. The small separation between the annual values of mean streamflow and base flow graphically shows that these basins on average are dominated by groundwater discharge and that surface runoff is only a small component of streamflow. As the period of record increases, the individual mean annual flow characteristics can be plotted against the respective range of normal conditions to assess drought severity and overall trends.

More than 20 wells went dry or had diminished sustainable yields during the drought between 1999 and 2002. A majority of these wells were located in the Dry Marsh Run groundwater area, and these failures may be attributed to the low relief $(231 \mathrm{ft})$ between drainage divide and stream outlet and to the large range of water-level fluctuations (9.44 to $87.84 \mathrm{ft}$ ) when compared to the other areas of the county (table 2). During drought conditions, the volume of water available for withdrawal from the upper parts of the aquifer system is greatly reduced as the water table declines. These declines tend to be greatest beneath the elevated parts of each area. Declines in water levels can drain water-bearing zones and can limit the available drawdown in wells. For example, 


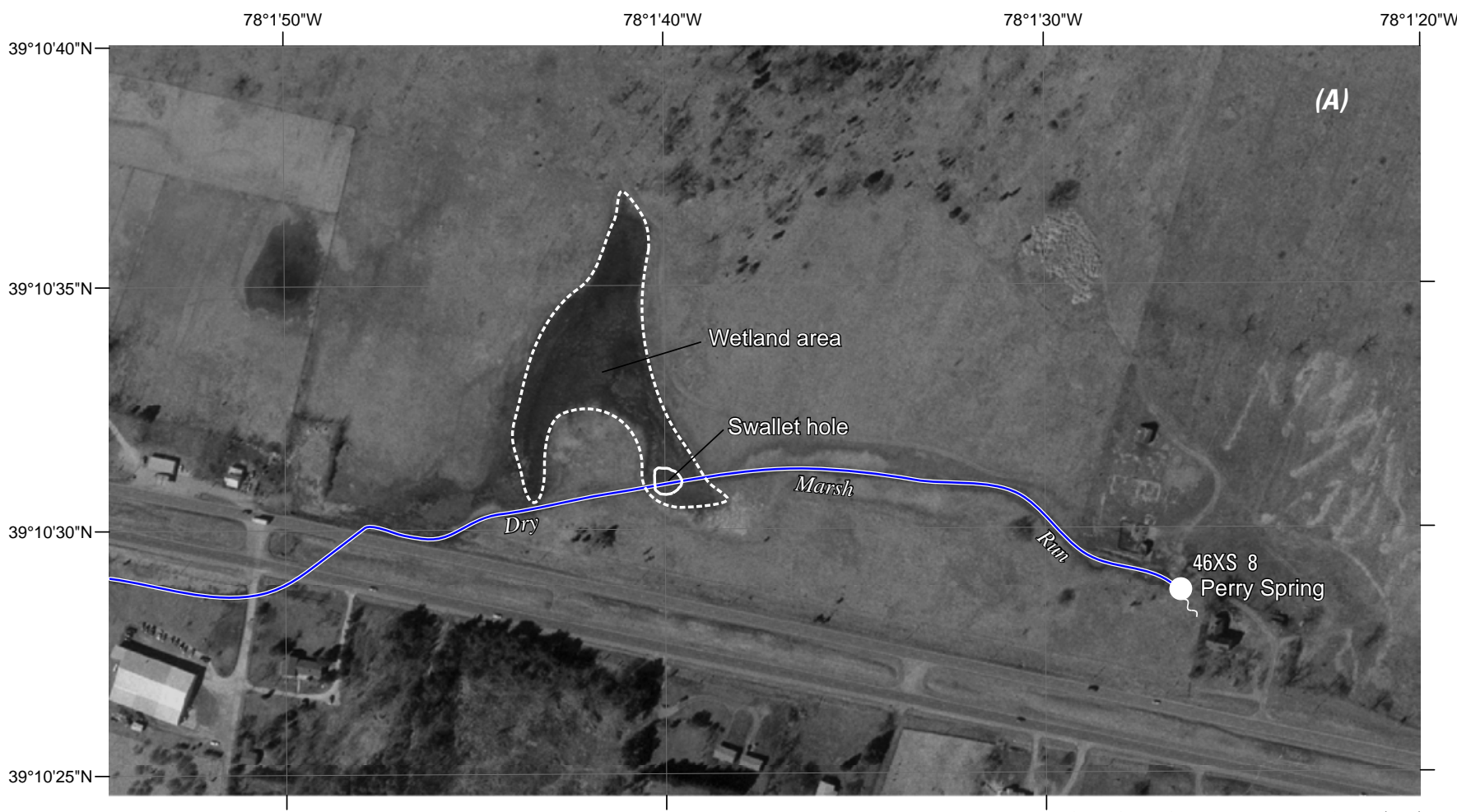

Aerial photography from Clarke County Geographic Information System (1996)

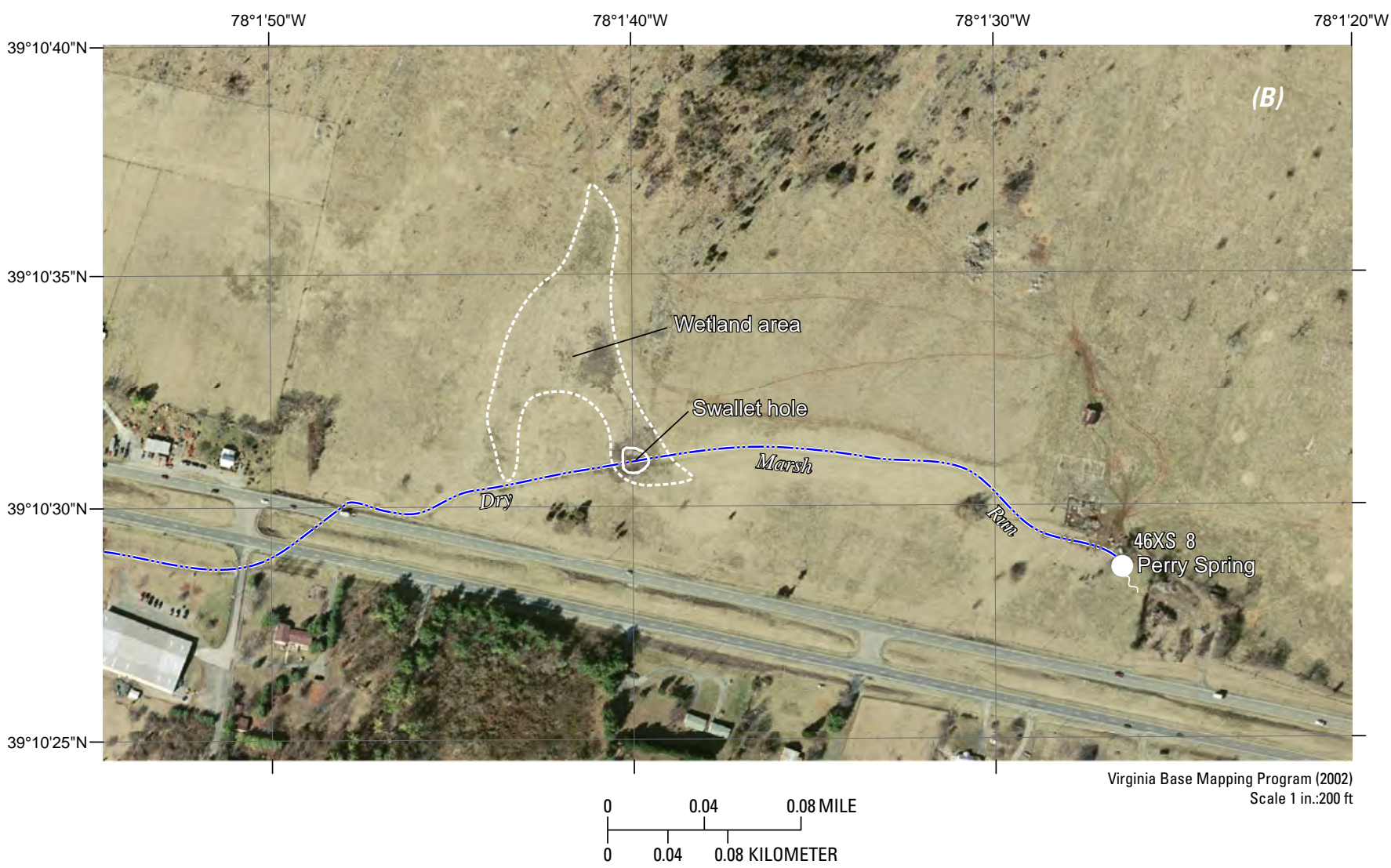

Figure 33. (A) Wet and (B) drought conditions in 1996 and 2002, respectively, for the area along Route 7 west of Berryville, Virginia, where Dry Marsh Run flows from spring 46XS 8 into a swallet hole and wetland area. 


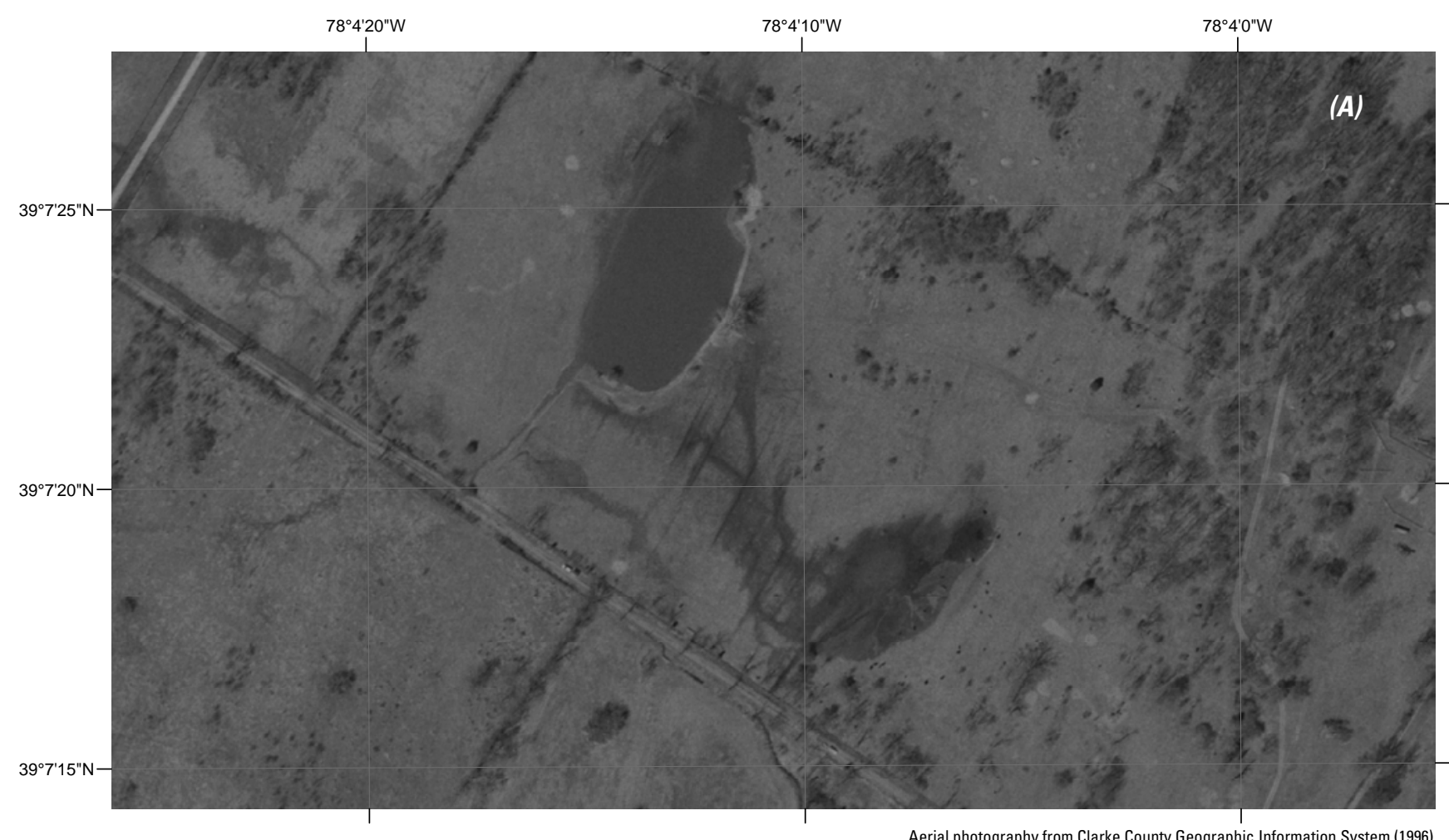

Aerial photography from Clarke County Geographic Information System (1996)

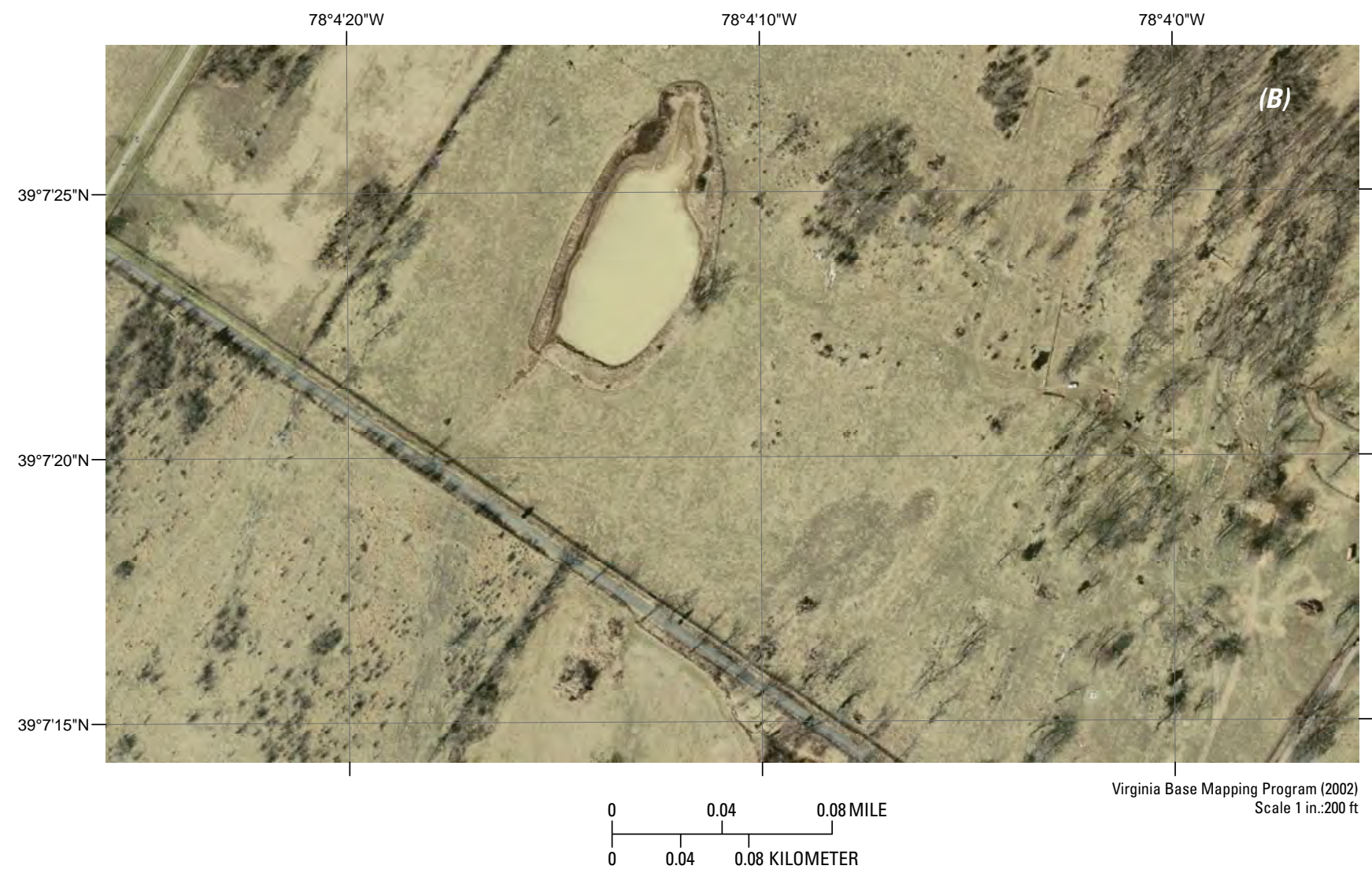

Figure 34. (A) Wet and (B) drought conditions in 1996 and 2002, respectively, for an area along Route 620 in Clarke County, Virginia, where groundwater overflows along bedding and joints (darker tones) in the carbonate rock during wet periods. Strike of the bedding is in northeast-southwest direction. 

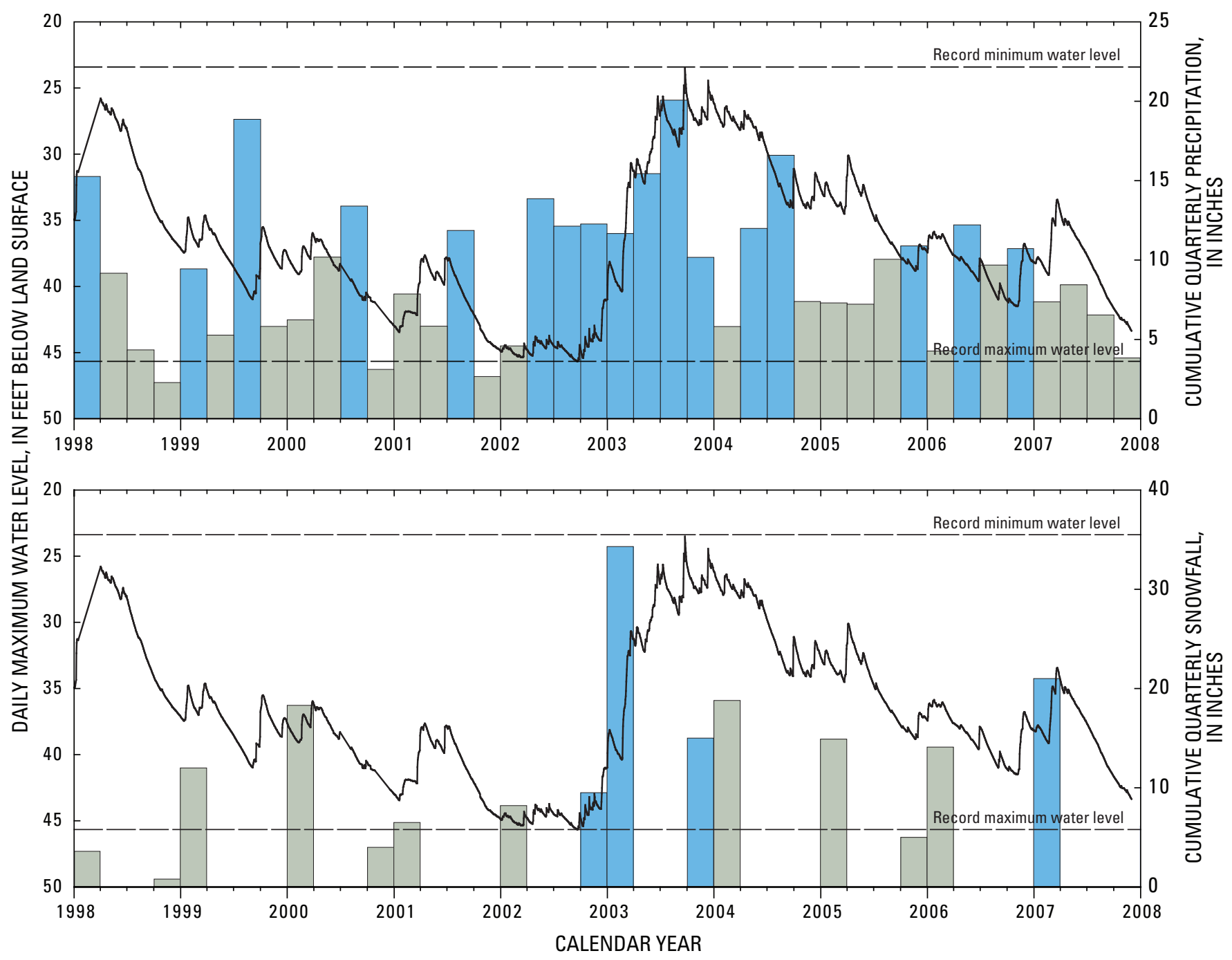

EXPLANATION

CUMULATIVE QUARTERLY PRECIPITATION AND SNOWFALL AT WINCHESTER 7 SE STATION, IN INCHES

\begin{tabular}{|l|l}
\hline & Above normal \\
Below normal & \\
\hline \hline$\quad$ DAILY MAXIMUM WATER LEVEL IN WELL 46W175, \\
IN FEET BELOW LAND SURFACE
\end{tabular}

Figure 35. Relation between daily maximum water levels in well $46 \mathrm{~W} 175$ and cumulative quarterly precipitation and snowfall at National Weather Service climatological station 449186 Winchester 7 SE, Virginia, 1998-2007. 


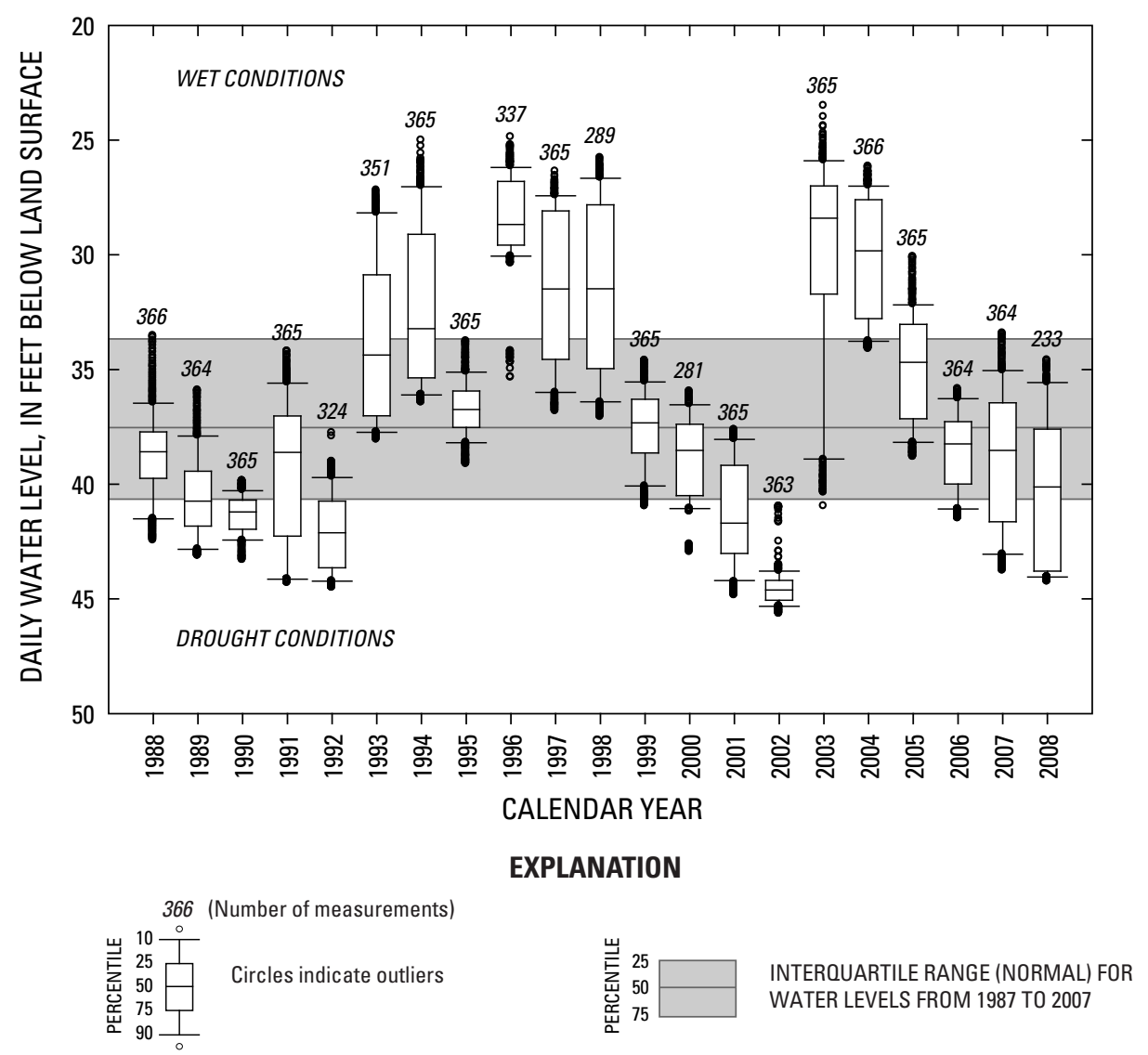

Figure 36. Statistical distribution of daily maximum water levels in well $46 \mathrm{~W} 175$ by calendar year, 1988-2008.

figure 38 illustrates the relation between the altitude of the outlet at streamflow gaging station 01616100 and the Dry Marsh Run drainage basin, where relief is $177 \mathrm{ft}$. During dry conditions, the flow in Dry Marsh Run comes only from the springs approximately $1,000 \mathrm{ft}$ upstream from the gage. Calculations of gravity drainage of the volume of the aquifer above the base level of the gage indicate that a large portion of this volume could be drained during prolonged drought conditions. Wells in the elevated parts of the basin that are either less than $177 \mathrm{ft}$ deep or obtain water from zones that are less than $177 \mathrm{ft}$ bls are therefore susceptible to failure during prolonged drought conditions as indicated by large water-level declines. The basin relief values for the Great Valley groundwater areas (table 2) could possibly be used to predict which wells may be affected by prolonged drought conditions. In the Blue Ridge, the use of basin relief values as indicators of well-failure susceptibility during prolonged drought conditions seems unreasonable because of the large basin relief values, which would equate to large aquifer volumes with low drainage rates.

Several wells that were reported to be dry in early 2002 had recovered by October 2002. The combination of a lack of precipitation, large water-level fluctuations, shallow depth of water-bearing zones, and overall hydrogeologic setting is the most probable explanation for the well failures during the recent drought. The cessation of meteorological drought conditions does not necessarily mean that groundwater conditions are normal. Water-resource managers need knowledge about the average rates of water-level recovery to anticipate the end of hydrologic drought conditions. Between October 2002 and April 2003, median rates of water-level recovery (table 6) were greatest in the Borden Marsh, Dry Marsh, and Spout Runs groundwater areas $(0.14,0.19$, and $0.11 \mathrm{ft} / \mathrm{d}$, respectively), and the largest recovery rates were observed in the elevated parts of these areas. Interestingly, the median rates of recovery in the remaining Great Valley and Blue Ridge groundwater areas were similar. In these areas, the changes in water levels were less than in the Dry Marsh Run area, possibly in response to the regional influence of the Shenandoah River.

The extent of drought conditions is difficult to forecast, and usually these conditions are not identified until an area has been in a drought for some period of time. Generally, water levels, spring discharges, and streamflows at the end of the critical recharge period can be used as initial guides for what the seasonal low conditions will be in late summer and early autumn. The seasonal high conditions determine the seasonal lows. 


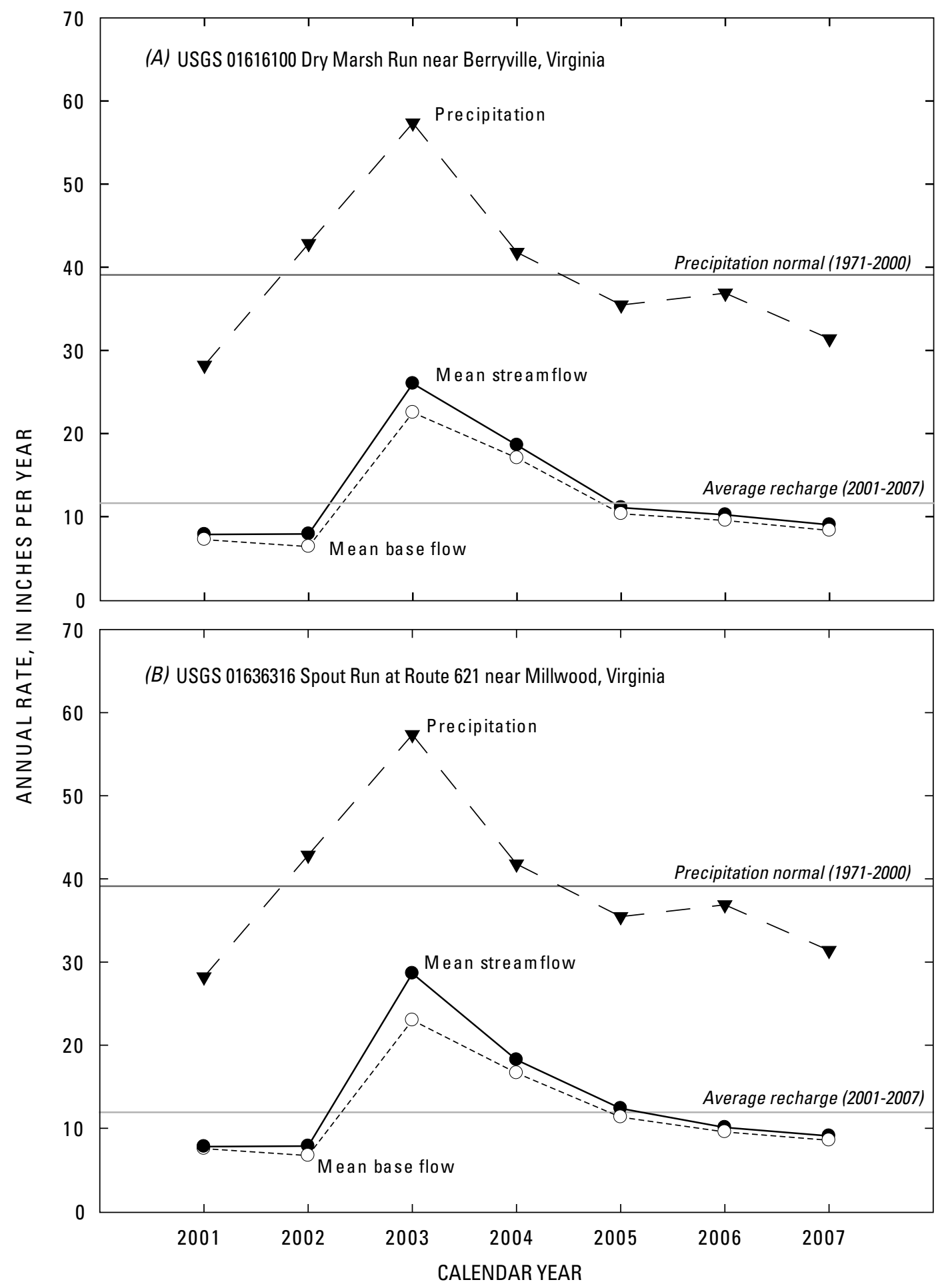

Figure 37. Relation among annual rates of precipitation at National Weather Service climatological station 449186 Winchester 7 SE, Virginia, (A) mean streamflow and mean base flow at streamflow gaging stations 01616100 Dry Marsh Run near Berryville, Virginia, and (B) 01636316 Spout Run at Route 621 near Millwood, Virginia. Mean streamflow and mean base-flow rates for the years 2001-2002 were estimated based on linear regression with streamflow gaging station 01614830 0pequon Creek at Route 11 near Stephens City, Virginia. Mean streamflow and mean base-flow rates for the years 2003-2007 were estimated from the streamflow partitioning software package PART (Rutledge, 1993). 


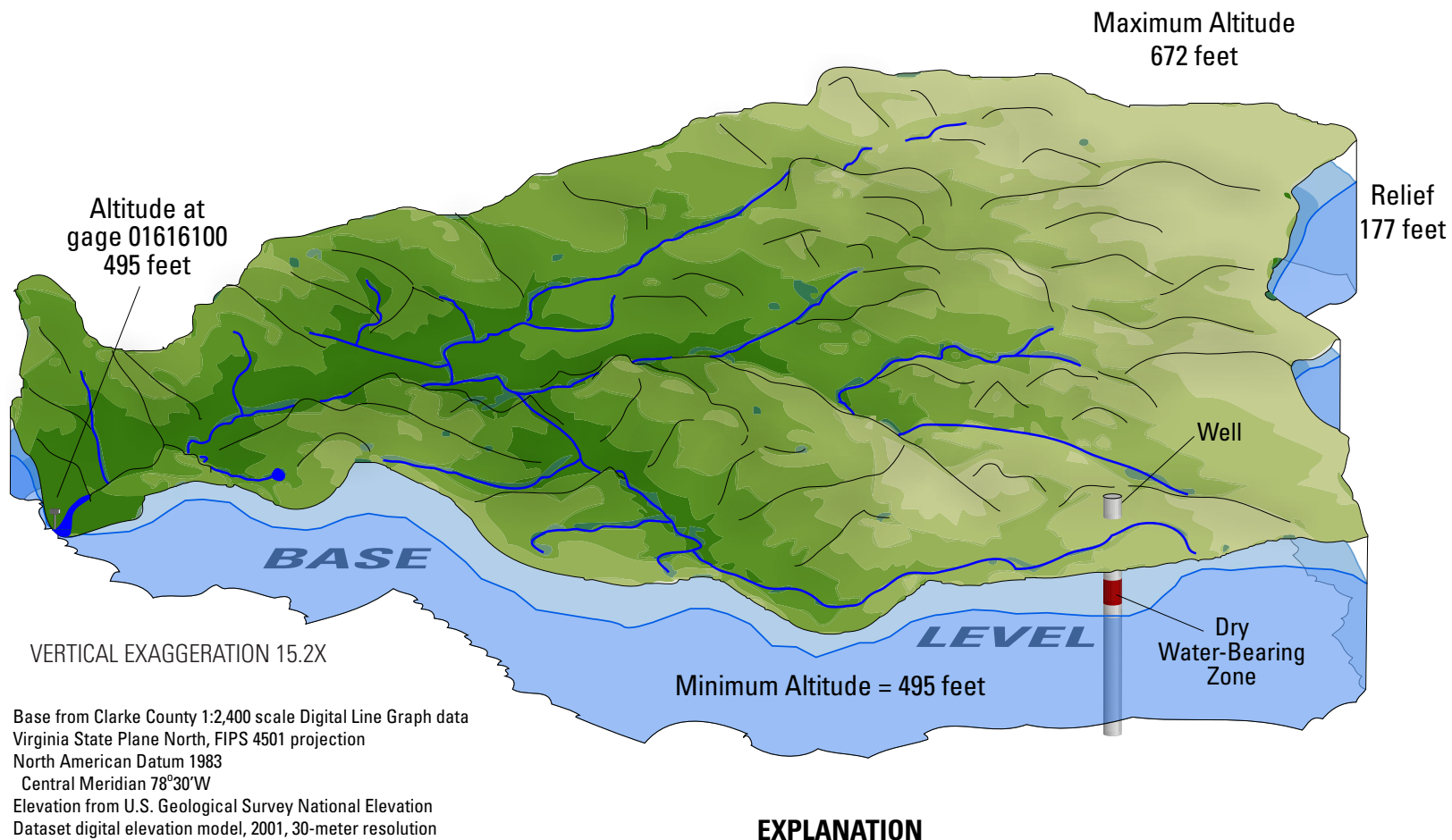

LAND-SURFACE ALTITUDE,

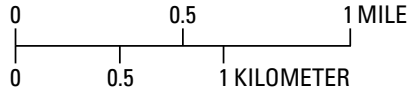

IN FEET ABOVE NGVD 29

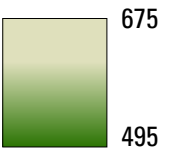

Figure 38. Schematic showing relation between watershed volume above the altitude of streamflow gaging station 01616100 Dry Marsh Run near Berryville in Clarke County, Virginia, and occurrence of dry wells.

Table 6. Median rates of quarterly water-level recovery from the 1999-2002 drought for the groundwater areas in Clarke County, Virginia.

[Water-level recovery rates are in feet per day. n, number of wells; nd, not determined; Shaded columns indicate Blue Ridge areas, and unshaded columns indicate Valley and Ridge areas. See figure 24 for location of groundwater areas]

\begin{tabular}{|c|c|c|c|c|c|c|c|c|c|c|}
\hline \multirow[b]{3}{*}{ Time period } & \multicolumn{9}{|c|}{ Groundwater area } & \multirow[b]{3}{*}{ County } \\
\hline & B01-BR & B01-VR & B02-BR & B02-VR & B03-BR & B03-VR & B04-VR & B54-VR & B55-VR & \\
\hline & $\begin{array}{c}\text { Raven } \\
\text { Rocks } \\
\text { Run }\end{array}$ & $\begin{array}{c}\text { Long } \\
\text { Marsh } \\
\text { Run }\end{array}$ & $\begin{array}{c}\text { Morgan } \\
\text { Mill }\end{array}$ & $\begin{array}{l}\text { Spout } \\
\text { Run }\end{array}$ & $\begin{array}{c}\text { Rock } \\
\text { Spring } \\
\text { Branch }\end{array}$ & $\begin{array}{c}\text { Borden } \\
\text { Marsh } \\
\text { Run }\end{array}$ & $\begin{array}{c}\text { Crooked } \\
\text { Run }\end{array}$ & $\begin{array}{c}\text { Dry } \\
\text { Marsh } \\
\text { Run }\end{array}$ & $\begin{array}{c}\text { Opequon } \\
\text { Creek }\end{array}$ & \\
\hline $\begin{array}{l}\text { Oct. } 2002 \text { to } \\
\text { Jan. } 2003\end{array}$ & 0.03 & 0.04 & 0.06 & 0.04 & nd & 0.16 & nd & 0.25 & 0.08 & 0.09 \\
\hline $\begin{array}{c}\text { Oct. } 2002 \text { to } \\
\text { Apr. } 2003\end{array}$ & 0.06 & 0.07 & 0.04 & 0.11 & nd & 0.14 & nd & 0.19 & 0.06 & 0.12 \\
\hline $\mathrm{n}$ & 6 & 7 & 3 & 6 & nd & 3 & nd & 17 & 4 & 46 \\
\hline
\end{tabular}




\section{Summary}

A study was conducted between October 2002 and October 2008 by the U.S. Geological Survey (USGS), in cooperation with Clarke County, VA, to describe the hydrogeology and groundwater availability in the county and to establish a long-term water monitoring network. The study area encompasses approximately 177 square miles and includes the carbonate and siliciclastic rocks of the Great Valley section of the Valley and Ridge and the metamorphic rocks of the Blue Ridge. The groundwater flow systems are complex and are controlled by the extremely folded and faulted geology that underlies the county. Increasing growth and the prolonged drought between 1999 and 2002 drew attention in the county to the quantity and sustainability of the groundwater resources.

The hydrogeologic units, which are based on mapped geologic units, are grouped into three major rock types: (1) carbonate-limestone and dolostone; (2) metamorphicmetavolcanic and metasedimentary rocks; and (3) siliciclastic — sandstone, siltstone, and shale. The hydrogeologic characteristics vary among these units and among the major rock-type groupings. In the Great Valley, the dominant flow direction is along the strike of the bedding-plane partings and thrust faults, which strike from N. $10^{\circ} \mathrm{E}$ to N. $20^{\circ}$ E. Groundwater movement normal to the strike, however, follows dip and oblique joints and cross-strike faults. Dips of beddingplane partings and the various joint types are highly variable, range from horizontal to vertical, and can be overturned, but are generally between 10 and $80^{\circ}$ to the northwest or southeast. Steeply dipping beds are prevalent in the county because of their location on the highly deformed eastern limb of the Massanutten synclinorium.

In the Blue Ridge, topography is the driving force behind groundwater flow, and water levels more closely mimic land surface. Flow in the bedrock in the Blue Ridge is controlled primarily by the irregular fracture network and steep terrain. The high density of streams in the Blue Ridge is characteristic of areas underlain by low permeability rocks. The porous nature of the regolith material or overburden and sharp contrast in permeability with the underlying bedrock coupled with numerous streams and steep terrain are conducive for the development of local-flow systems. Subsurface stormflow through the porous overburden moves rapidly to streams and springs in the Blue Ridge because of the steep terrain. Conceptualization of the groundwater flow system in the siliciclastic rocks on the western edge of the county, underlain by the Martinsburg Formation, is more similar to the Blue Ridge than the carbonate rocks of the Great Valley. Subsurface stormflow is probably a minor factor because of the lack of regolith material overlying the Martinsburg Formation and less steep terrain. Evapotranspiration, and to a lesser extent, runoff, may be greater because of the low permeability of the rock and the absence of regolith material.

Sinkholes, caves, caverns, estavelles, and sinking and dry streams are characteristic features of karst terrain. Lithologic characteristics, fracture density, proximity of carbonate rock to streams, land slope, and geologic structure are controlling factors in sinkhole development. Steep hydraulic gradients and increased rate of groundwater flow near incised streams may contribute to the abundance and increased size of sinkholes in areas near Opequon Creek and Shenandoah River. Sinkholes frequently develop in the noses of anticlines and synclines, and usually form in elevated and flat (less than 5-degree slope) areas. Sinkhole development during well construction and pumping is well documented. The greatest density of sinkholes in the county is in the northwest part in the Dry Marsh Run area.

Conduit- and diffuse-flow conditions are present in the karst aquifer systems, and the diffuse-flow conditions are present in areas underlain by the siliciclastic and metamorphic rocks. Generally, groundwater is under unconfined or watertable conditions. During wet periods, however, semiconfined to confined conditions can exist, and hydraulic head is dissipated as overflow on the land surface. These overflow areas in the Great Valley section, which are locally referred to as wet weather springs, do not represent convergence of flow lines, but simply represent pressure release from the flow system that frequently occurs along the axes of folds.

High-yielding wells generally tend to cluster along faults, within lineament zones, and in areas of tight folding throughout the county. A comparison of density clusters indicates that some areas contain a dense concentration of low- and high-yielding wells, which illustrates the degree of complexity inherent with karst and fractured-rock aquifer systems. Waterbearing zones are generally encountered within 250 feet (ft) of land surface. However, median depths are slightly deeper for the hydrogeologic units of the Blue Ridge than those in the Great Valley section of the county. A large number of waterbearing zones are present between 400 and 1,000 ft below land surface.

Between October 2002 and October 2008, water-level fluctuations ranged from 2.86 to $87.84 \mathrm{ft}$ with an average of $24.15 \mathrm{ft}$. Seasonal water-level highs occur in the early spring at the end of the major groundwater recharge period, and lows occur in late autumn when evapotranspiration rates begin to decrease. Intense thunderstorms, tropical storms, or hurricanes generally cause sudden, but temporary, water-level rises during the summer and autumn. Water-level fluctuations generally were greatest near hydrologic divides, in isolated elevated areas, and in the Opequon Creek Basin. An overall downward trend in water levels between 2003 and 2008, which closely follows a downward trend in annual precipitation over the same period, was observed in a majority of wells in the Great Valley and in some of the wells in the Blue Ridge. Current meteorological conditions affect water-level fluctuations in the Blue Ridge, and seasonal highs and lows tend to shift in response to the current conditions.

Discharges from springs ranged from dry to 10 cubic feet per second $\left(\mathrm{ft}^{3} / \mathrm{s}\right)$ between March 2003 and October 2008. Springs in the Great Valley, and to a lesser degree in the Blue Ridge, generally are associated with faults and fold axes. 
A downward trend in discharges for the Great Valley springs correlates with the trend documented in water levels and is indicative of an aquifer system that over time drains to a base level that is controlled by springs and streams. Point discharge from springs can occur as the start of flows of streams and creeks, along banks, and as discrete discharge through streambeds in the Great Valley. For the most part, streams, creeks, and rivers in the Great Valley function as aqueducts. Springs in the Blue Ridge have relatively low discharge rates and small drainage areas and are susceptible to current meteorological conditions. Movement of water through the porous regolith to springs is predominantly controlled by subsurface stormflow rather than by discharge from the bedrock.

Nine groundwater areas were delineated based on basin boundaries in Clarke County. High altitudes with relief greater than 1,400 ft, steep slopes, low sinkhole density, high stream density, mean annual precipitation of more than 40 inches per year (in/yr), and relatively large differences between minimum and maximum annual precipitation across the areas are characteristic of groundwater areas in the Blue Ridge. Low altitudes with relief less than $350 \mathrm{ft}$, gentle slopes, high sinkhole density, low stream density, mean annual precipitation of about $39 \mathrm{in} / \mathrm{yr}$, and less areal variability in precipitation are characteristic of the Great Valley groundwater areas. The greatest range between the minimum and maximum water levels measured between October 2002 and October 2008 occurred in the Dry Marsh Run groundwater area, where numerous geologic structures (faults and lineament zones) cross and intersect. Low stream density and large water-level fluctuations indicate that this area is underlain by permeable rocks. The relatively deep water-bearing zones with large water-level fluctuations indicate that permeability maybe present to considerable depth. The combination of all of these factors can explain the high density of sinkholes, numerous dry stream segments during the majority of the study period, and the high occurrence of dry wells during the prolonged drought between 1999 and 2002 in the Dry Marsh Run area.

Apparent groundwater ages from 15 springs ranged from 1.1 to 21.6 years. Apparent ages of the young fraction that were less than 5 years were estimated in nearly half of the springs sampled. Of the remaining springs, 75 percent contained waters with apparent ages greater than 10 years. The percentage of the young fraction in binary mixtures ranged from approximately 73 to nearly 96 percent. These high percentages indicate that a majority of the water discharging from the springs is young and is close to being piston flow. Springs in the upper reaches of the basins tend to have young apparent ages and binary mixtures, and the older ages are present in the lower reaches.

Estimates of effective groundwater recharge for 20012007 ranged from 6.4 to $22.5 \mathrm{in} / \mathrm{yr}$ in the Dry Marsh Run Basin with an average of 11.6 in/yr. Base flow accounted for between 81 and 93 percent of mean streamflow with an average of 90 percent during the same period. Effective recharge rates for 2001-2007 in the Spout Run Basin ranged from 6.7 to $23.0 \mathrm{in} / \mathrm{yr}$ with an average of $11.9 \mathrm{in} / \mathrm{yr}$. Base flow accounted for between 80 and 97 percent of mean streamflow with an average of 91 percent during the same period. The high base-flow index values (percentage of streamflow from base flow) in the Dry Marsh Run and Spout Run Basins indicate that groundwater is the dominant source of streamflow during wet and drought conditions.

Water-budget data indicate that between 46 and 82 percent of the precipitation that fell on the Dry Marsh Run and Spout Run Basins between 2001 and 2007 was removed by evapotranspiration, and approximately 30 percent of the precipitation reached the water table as effective recharge. The high permeability of the rocks and low relief in these basins are not conducive for runoff; therefore, on average, only about 3 to 4 percent of the precipitation becomes runoff. Current water use is a small component of the overall budget.

Groundwater flow systems in the county are extremely vulnerable to current climatic conditions. Successive years of below-average effective recharge cause declines in water levels, spring discharges, and streamflows. However, these systems can recover quickly as effective recharge increases, especially in the Dry Marsh Run area. Effective recharge tends to increase as precipitation increases, but lack of precipitation, especially snow, during the critical recharge periods can have a substantial effect on the amount of recharge. Daily water levels recorded in well 46W175 in 2002 were below the normal range, and the majority of these water levels were the lowest recorded since 1987. The combination of a lack of precipitation, large water-level fluctuations, depths to water-bearing zones, and hydrogeologic setting is the most probable explanation for the well failures during the recent drought. 


\section{References Cited}

Allen, D.M., and Michel, F.A., 1999, Characterizing a faulted aquifer by field testing and numerical simulation: Ground Water, v. 37, no. 5, p. 718-728.

Badger, R.L., and Sinha, A.K., 1988, Age and Sr isotopic signature of the Catoctin volcanic province-Implication for subcrustal mantle evolution: Geology, v. 16, no. 8, p. 692-695.

Bayer, R., Schlosser, Peter, Bönisch, G., Rupp, H., Zaucker, F., and Zimmek, G., 1989, Performance and blank components of a mass spectrometric system for routine measurement of helium isotopes and tritium by the ${ }^{3} \mathrm{He}$ ingrowth method: Sitzungsberichte der Heidelberger Akademie der Wissenschaften, Mathematisch-naturwissenschaftliche Klasse, Jahrgang 1989, 5. Abhandlung, Springer-Verlag, 42 p.

Bredehoeft, J.D., 2002, The water budget myth revisitedWhy hydrogeologists model: Ground Water, v. 40, no. 4, p. 340-345.

Brezinski, D.K., 1992, Lithostratigraphy of the western Blue Ridge cover rocks in Maryland: Maryland Geological Survey, Report of Investigations no. 55, 69 p., scale 1:62,500.

Brezinski, D.K., Anderson, T.H., and Campbell, P., 1996, Evidence for a regional detachment at the base of the Great Valley sequence in the central Appalachians: Studies in Maryland Geology, Special Publication No. 3, p. 223-229.

Busenberg, Eurybiades, and Plummer, L.N., 1992, Use of chlorofluorocarbons $\left(\mathrm{CCl}_{3} \mathrm{~F}\right.$ and $\left.\mathrm{CCl}_{2} \mathrm{~F}_{2}\right)$ as hydrologic tracers and age-dating tools-The alluvium and terrace system of central Oklahoma: Water Resources Research, v. 28, no. 9, p. 2257-2283.

Busenberg, Eurybiades, and Plummer, L.N., 2000, Dating young ground water with sulfur hexafluoride-Natural and anthropogenic sources of sulfur hexafluoride: Water Resources Research, v. 36, p. 3011-3030.

Busenberg, Eurybiades, Weeks, E.P., Plummer, L.N., and Bartholomay, R.C., 1993, Age dating ground water by use of chlorofluorocarbons $\left(\mathrm{CCl}_{3} \mathrm{~F}\right.$ and $\left.\mathrm{CCl}_{2} \mathrm{~F}_{2}\right)$ and distribution of chlorofluorocarbons in the unsaturated zone, Snake River Plain aquifer, Idaho National Engineering Laboratory, Idaho: U.S. Geological Survey Water-Resources Investigations Report 93-4054, 47 p.

Cady, R.C., 1936, Ground-water resources of the Shenandoah Valley, Virginia: Virginia Geological Survey, Bulletin 45, $137 \mathrm{p}$.

Cady, R.C., 1938, Ground-water resources of northern Virginia: Virginia Geological Survey, Bulletin 50, 200 p.
Cederstrom, D.J., 1972, Evaluation of yields of wells in consolidated rocks, Virginia to Maine: U.S. Geological Survey Water-Supply Paper 2021, 38 p.

Clark, I.D., and Fritz, Peter, 1997, Environmental isotopes in hydrogeology: New York, Lewis Publishers, 328 p.

Clarke, W.B., Jenkins, W.J., and Top, Z., 1976, Determination of tritium by mass spectrometric measurement of ${ }^{3} \mathrm{He}$ : International Journal of Applied Radiation and Isotopes, v. 27, p. 515-522.

Coplen, T.B., 1988, Normalization of oxygen and hydrogen isotope data: Chemical Geology, v. 72, no. 4, p. 293-297.

Coplen, T.B., 1996, New guidelines for reporting stable hydrogen, carbon, and oxygen isotope-ratio data: Geochimica Cosmochimica Acta, v. 60, p. 3359-3360.

Cressler, C.W., Thurmond, C.J., and Hester, W.G., 1983, Ground water in the greater Atlanta region: Georgia Department of Natural Resources Environmental Protection Division, Georgia Geologic Survey Information Circular 63, 144 p.

Daniel, C.C., III, 1989, Statistical analysis relating well yield to construction practices and siting of wells in the Piedmont and Blue Ridge Provinces of North Carolina: U.S. Geological Survey Water-Supply Paper 2341-A, p. 27.

Davis, A.M., Southworth, C.S., Reddy, J.E., and Schindler, J.S., 2001, Geologic map database of the Washington DC area featuring data from three 30 × 60 minute quadranglesFrederick, Washington West, and Fredericksburg, Version 1.0: U.S. Geological Survey Open-File Report 01-227, scale 1:100,000, $10 \mathrm{p}$.

Di Luzio, Mauro, Johnson, G.L., Daly, Christopher, Eischeid, J.K., and Arnold, J.G., 2008, Constructing retrospective gridded daily precipitation and temperature datasets for the conterminous United States: Journal of Applied Meteorology and Climatology, v. 47, no. 2, p. 475-497.

Doctor, D.H., Weary, D.J., Orndorff, R.C., Harlow, G.E., Jr., Kozar, M.D., and Nelms, D.L., 2008, Bedrock structural controls on the occurrence of sinkholes and springs in the northern Great Valley karst, Virginia and West Virginia, in Yuhr, L.B., Alexander, E.C., Jr., and Beck, B.F., eds., Proceedings of the 11th Multidisciplinary Conference on Sinkholes and Engineering and Environmental Impacts of Karst, Tallahassee, Florida, September 23-26, 2008, p. 12-22.

Earth Science Australia, 2004, Joint patterns in folds, accessed April 12, 2004, at http://earthsci.org/struct/fault/joint3.gif.

Edmonds, W.J., and Stiegler, James, 1982, Soil survey of Clarke County, Virginia: U.S. Department of Agriculture, Soil Conservation Service, 211 p. 
Edmundson, R.S., 1945, Industrial limestones and dolomites in Virginia; northern and central parts of the Shenandoah Valley: Virginia Geological Survey Bulletin 65, 195 p.

Edmundson, R.S., and Nunan, W.E., 1973, Geology of the Berryville, Stephenson, and Boyce quadrangles, Virginia: Virginia Division of Mineral Resources Report of Investigations 34, scale 1:24,000, $112 \mathrm{p}$.

Ekwurzel, B., Schlosser, Peter, Smethie, W., Jr., Plummer, L.N., Busenberg, Eurybiades, Michel, R.L., Weppernig, R., and Stute, Martin, 1994, Dating of shallow groundwaterComparison of the transient tracers ${ }^{3} \mathrm{H} /{ }^{3} \mathrm{He}$, chlorofluorocarbons, and ${ }^{85} \mathrm{Kr}$ : Water Resources Research, v. 30, no. 6, p. 1693-1708.

Epstein, J.B., Orndorff, R.C., and Rader, E.K., 1995, Middle Ordovician Stickley Run Member (new name) of the Martinsburg Formation, Shenandoah Valley, northern Virginia, in Stratigraphic Notes, 1994-Three short papers propose changes in stratigraphic nomenclature in Virginia, Kentucky, and Alaska: U.S. Geological Survey Bulletin 2135, p. 1-13.

Fenneman, N.M., 1938, Physiography of Eastern United States: New York, McGraw-Hill, 534 p.

Focazio, M.J., Plummer, L.N., Böhlke J.K., Busenberg, E., Bachman, L.J., and Powars, D.S., 1998, Preliminary estimates of residence times and apparent ages of ground water in the Chesapeake Bay watershed, and water-quality data from a survey of springs: U.S. Geological Survey WaterResources Investigations Report 97-4225, 75 p.

Gathright, T.M., Jr., and Nystrom, P.G., Jr., 1974, Geology of the Ashby Gap quadrangle, Virginia: Virginia Division of Mineral Resources Report of Investigations 36, scale 1:24,000, $55 \mathrm{p}$.

Hack, J.T., 1965, Geomorphology of the Shenandoah Valley, Virginia and West Virginia, and origin of the residual ore deposits: U.S. Geological Survey Professional Paper 484, $84 \mathrm{p}$.

Hack, J.T., and Young, R.S., 1959, Entrenched meanders of the North Fork of the Shenandoah River, Virginia: U.S. Geological Survey Professional Paper 354-A, p. 1-10.

Hagedorn, Charles, Robinson, Sandra, Reneau, R.B., Jr., and Teetor, Alison, 1998, A method to determine sources of fecal pollution, in Water-Proceedings 7th Annual Meeting, National Onsite Wastewater Recycling Association, Ft. Mitchell, KY, p. 112-116.

Hansen, B.P., and Simcox, A.C., 1994, Yields of bedrock wells in Massachusetts: U.S. Geological Survey Water-Resources Investigations Report 93-4115, 43 p.
Harlow, G.E., Jr., Orndorff, R.C., Nelms, D.L., Weary, D.J., and Moberg, R.M., 2005, Hydrogeology and ground-water availability in the carbonate aquifer system of Frederick County, Virginia: U.S. Geological Survey Scientific Investigations Report 2005-5161, 30 p.

Harris, A.G., Stamm, N.R., Weary, D.J., Repetski, J.E., Stamm, R.G., and Parker, R.A., 1994, Conodont color alteration index (CAI) map and conodont-based age determinations for the Winchester $30^{\prime}$ x $60^{\prime}$ quadrangle and adjacent area, Virginia, West Virginia, and Maryland: U.S. Geological Survey Miscellaneous Field Studies Map MF-2239, scale 1:100,000, $40 \mathrm{p}$.

Healy, R.W., Winter, T.C., LaBaugh, J.W., and Franke, O.L., 2007, Water budgets-Foundations for effective waterresources and environmental management: U.S. Geological Survey Circular 1308, 90 p.

Heaton, T.H.E., 1981, Dissolved gases-Some applications to ground-water research: Transactions of the Geological Society of South Africa, v. 84, p. 91-97.

Heaton, T.H.E., Talma, A.S., and Vogel, J.C., 1983, Origin and history of nitrate in confined groundwater in the Western Kalahari: Journal of Hydrology, v. 62, p. 243-262.

Heaton, T.H.E., and Vogel, J.C., 1981, Excess air in groundwater: Journal of Hydrology, v. 50, p. 201-216.

Hely, A.G., and Olmsted, F.H., 1963, Some relations between streamflow characteristics and the environment in the Delaware River region: U.S. Geological Survey Professional Paper 417-B, 21 p.

Hinkle, K.R., and Sterrett, R.M., 1976, Rockingham County groundwater, present conditions and prospects: Virginia State Water Control Board Planning Bulletin 300, 88 p.

Hinkle, K.R., and Sterrett, R.M., 1977, Shenandoah County groundwater, present conditions and prospects: Virginia State Water Control Board Planning Bulletin 306, 67 p.

Hinkle, K.R., and Sterrett, R.M., 1978, Augusta County groundwater, present conditions and prospects: Virginia State Water Control Board Planning Bulletin 310, 119 p.

Hubbard, D.A., Jr., 1983, Selected karst features of the northern Valley and Ridge province, Virginia: Virginia Division of Mineral Resources Publication 144, scale 1:250,000.

Hubbard, D.A., Jr., 1990, Geologic map of Clarke County, Virginia and map of selected hydrogeologic components for Clarke County, Virginia: Virginia Division of Mineral Resources Publication 102, scale 1:50,000.

Hutson, S.S., Barber, N.L., Kenny, J.F., Linsey, K.S., Lumia, D.S., and Maupin, M.A., 2004, Estimated use of water in the United States in 2000: U.S. Geological Survey Circular 1268, 46 p. 
Hyland, S.E., Kennedy, L.M., Younos, Tamim, and Parson, Shane, 2006, Analysis of sinkhole susceptibility and karst distribution in the Northern Shenandoah Valley, Virginia: Virginia Water Resources Research Center Special Report SR31-2006, 75 p.

International Atomic Energy Agency (IAEA), 1981, Statistical treatment of environmental isotope data in precipitation: Vienna, IAEA, Technical Report Series No. 206.

Jones, W.K., 1987, Overview of groundwater resources of Clarke County, Virginia, with emphasis on the carbonate aquifers west of the Shenandoah River, in Clarke County Groundwater Protection Plan, Lord Fairfax Planning District Commission, p. 7.1-7.22.

Keyworth, A.J., 2009, A quantitative assessment of water inputs and outputs to a small watershed in northwestern Wake County-Evaluating the effects of human use on groundwater resources: Master's thesis, North Carolina State University, Department of Marine, Earth, and Atmospheric Sciences, 81 p., accessed August 2009 at http:// www.lib.ncsu.edu/theses/available/etd-11132008-153043/ unrestricted/etd.pdf.

Kozar, M.D., Paybins, K.S., Weary, D.J., and Pierce, H.A., 2007, Hydrogeologic setting and ground-water flow in the Leetown area, West Virginia: U.S. Geological Survey Scientific Investigations Report 2007-5066, 70 p.

Kozar, M.D., and Weary, D.J., 2009, Hydrogeology and ground-water flow in the Opequon Creek watershed area, Virginia and West Virginia: U.S. Geological Survey Scientific Investigations Report 2009-5153, 61 p.

Landers, M.N., and Ankcorn, P.D., 2008, Methods to evaluate influence of onsite septic wastewater-treatment systems on base flow in selected watersheds in Gwinnett County, Georgia, October 2007: U.S. Geological Survey Scientific Investigations Report 2008-5220, 12 p. (Also available at http://pubs.usgs.gov/sir/2008/5220/.)

Lane, J.W., Jr., Day-Lewis, F.D., Johnson, C.D., Dawson, C.B., Nelms, D.L., Eddy-Miller, C.A., Wheeler, J.D., Harvey, C.F., and Karam, Hanan, 2008, Fiber-optic distributed temperature sensing-A new tool for assessment and monitoring of hydrologic processes, in Symposium on the Application of Geophysics to Engineering and Environmental Problems (SAGEEP), April 6-10, 2008, Philadelphia, PA, Proceedings: Denver, CO, Environmental and Engineering Geophysical Society, 9 p.

Lindsey, B.D., Phillips, S.W., Donnelly, C.A., Speiran, G.K., Plummer, L.N., Böhlke, J.K., Focazio, M.J., Burton, W.C., and Busenberg, Eurybiades, 2003, Residence times and nitrate transport in ground water discharging to streams in the Chesapeake Bay Watershed: U.S. Geological Survey Water-Resources Investigations Report 03-4035, 201 p.
LoCastro, R.P., 1988, The influence of geology and agriculture on groundwater quality in Clarke and Frederick Counties, Virginia: University of Virginia, Master’s Thesis, 180 p.

Loiselle, Marc, and Evans, David, 1995, Fracture density distributions and well yields in Coastal Maine: Ground Water, v. 33, no. 2, p. 190-196.

Ludin, Andrea, Weppernig, Ralf, Bönisch, Gerhard, and Schlosser, Peter, 1998, Mass spectrometric measurement of helium isotopes and tritium in water samples: LamontDoherty Earth Observatory, Columbia University, Palisades, New York. Technical Report 98.6.

Lukert, M.L., III, and Nuckols, E.B., II, 1976, Geology of the Linden and Flint Hill quadrangles, Virginia with $a$ section on Hydrogeology, by R.H. DeKay: Virginia Division of Mineral Resources Report of Investigations 44, scale 1:24,000, $83 \mathrm{p}$.

McCoy, K.J., Podwysocki, M.H., Crider, E.A., and Weary, D.J., 2005a, Fracture trace map and single-well aquifer test results in a carbonate aquifer in Berkeley County, West Virginia: U.S. Geological Survey Open-File Report 2005-1040, 1 pl.

McCoy, K.J., Podwysocki, M.H., Crider, E.A., and Weary, D.J., 2005b, Fracture trace map and single-well aquifer test results in a carbonate aquifer in Jefferson County, West Virginia: U.S. Geological Survey Open-File Report 2005-1407, 1 pl.

Michel, R.M., 1989, Tritium deposition in the Continental United States, 1953-1983: U.S. Geological Survey WaterResources Investigations Report 89-4072, 46 p.

National Oceanic and Atmospheric Administration, 2006, Climatological data annual summary-Virginia: Asheville, NC, National Climatic Data Center, v. 116, no. 13, 24 p.

National Oceanic and Atmospheric Administration, 2008, Oceanic Niño Index (ONI), accessed December 2, 2008, at http://www.cpc.noaa.gov/products/analysis_monitoring/ ensostuff/ensoyears.shtml.

Nelms, D.L., and Harlow, G.E., Jr., 2003, Aquifer susceptibility in Virginia-Data on chemical and isotopic composition, recharge temperature, and apparent age of water from wells and springs, 1998-2000: U.S. Geological Survey Open-File Report 03-246, 101 p.

Nelms, D.L., Harlow, G.E., Jr., and Hayes, D.C., 1997, Baseflow characteristics of streams in the Valley and Ridge, the Blue Ridge, and the Piedmont Physiographic Provinces of Virginia: U.S. Geological Survey Water-Supply Paper 2457, $48 \mathrm{p}$. 
Nelms, D.L., and Moberg, R.M., 2008, Impact of 1998-2002 drought on the karst aquifers of Clarke County in the Shenandoah Valley of Virginia [abs.], in Kuniansky, E.L., ed., U.S. Geological Survey Karst Interest Group Proceedings, Bowling Green, Kentucky, May 27-29, 2008: U.S. Geological Survey Scientific Investigations Report 2008-5023, p. 51.

Nickelsen, R.P., 1956, Geology of the Blue Ridge near Harpers Ferry, West Virginia: Geological Society of America Bulletin, v. 67, no. 3, p. 239-269.

Nuckels, E.H., Prugh, B.J., Jr., Michaels, P.J., and Jones, D.R., 1991, National water summary 1988-89-Hydrologic events and floods and droughts: U.S. Geological Survey Water-Supply Paper 2375, p. 543-550.

Olmsted, F.H., and Hely, A.G., 1962, Relation between ground water and surface water in Brandywine Creek basin, Pennsylvania: U.S. Geological Survey Professional Paper 417-A, 21 p.

Orndorff, R.C., Epstein, J.B., and McDowell, R.C., 1999, Geologic map of the Middletown quadrangle, Frederick, Shenandoah, and Warren Counties, Virginia: U.S. Geological Survey Geologic Quadrangle Map GQ-1803, scale $1: 24,000$.

Orndorff, R.C., and Goggin, K.E., 1994, Sinkholes and karstrelated features of the Shenandoah Valley in the Winchester $30^{\prime}$ x $60^{\prime}$ quadrangle, Virginia and West Virginia: U.S. Geological Survey Miscellaneous Field Studies Map MF-2262, scale 1:100,000.

Orndorff, R.C., and Harlow, G.E., Jr., 2002, Field trip guideHydrogeologic framework of the Northern Shenandoah Valley carbonate aquifer system, in Kuniansky, E.L., ed., U.S. Geological Survey Karst Interest Group Proceedings, Shepherdstown, West Virginia, August 20-22, 2002: U.S. Geological Survey Water-Resources Investigations Report 02-4174, p. 81-89.

Paul, W.T., 2007, Water budget of mountain residence, Jefferson County, Colorado: Colorado School of Mines, Master's Thesis, $68 \mathrm{p}$.

Plummer, L.N., and Busenberg, Eurybiades, 2000, Chlorofluorocarbons, in Cook, P.G., and Herczeg, Andrew, eds., Environmental tracers in subsurface hydrology: Boston, Kluwer Academic Publishers, p. 441-478.
Plummer, L.N., Busenberg, Eurybiades, Böhlke, J.K., Carmody, R.W., Casile, G.C., Coplen, T.B., Doughten, M.W., Hannon, J.E., Kirkland, Wandee, Michel, R.L., Nelms, D.L., Norton, B.C., Plummer, K.E., Qi, Haiping, Revesz, Kinga, Schlosser, Peter, Spitzer, Shane, Wayland, J.E., and Widman, P.K., 2000, Chemical and isotopic composition of water from springs, wells, and streams in parts of Shenandoah National Park, Virginia, and vicinity, 1995-1999: U.S. Geological Survey Open-File Report 00-373, 70 p.

Plummer, L.N., Busenberg, E., Böhlke, J.K., Nelms, D.L., Michel, R.L., and Schlosser, P., 2001, Groundwater residence times in Shenandoah National Park, Blue Ridge Mountains, Virginia, USA-A multi-tracer approach: Chemical Geology, v. 179, p. 93-111.

Poff, Judy, ed., 1999, A homeowner’s guide to the development, maintenance, and protection of springs as a drinking water source: Virginia Water Resources Research Center Educational Report, 83 p.

Rader, E.K., and Gathright, T.M., II, 2001, Geologic map of the Front Royal 30 x 60-minute quadrangle-Portions of Clarke, Page, Rockingham, Shenandoah, and Warren Counties, Virginia: Virginia Division of Mineral Resources Publication 162, scale 1:100,000.

Rader, E.K., McDowell, R.C., Gathright, T.M., II, and Orndorff, R.C., 1996, Geologic Map of Clarke, Frederick, Page, Shenandoah, and Warren Counties, Virginia - Lord Fairfax Planning District: Virginia Division of Mineral Resources Publication 143, scale 1:100,000.

Rader, E.K., McDowell, R.C., Gathright, T.M., II, and Orndorff, R.C., 2001, Geologic map of the Virginia portion of the Winchester 30 x 60-minute quadrangle: Virginia Division of Mineral Resources Publication 161, scale 1:100,000.

Rader, E.K., McDowell, R.C., Gathright, T.M., II, and Orndorff, R.C., 2003, Raster images of the geologic map of the Virginia portion of the Winchester 30 x 60-minute quadrangle: Virginia Division of Mineral Resources Publication 171, Part A, scale 1:100,000.

Reed, J.C., Jr., 1955, Catoctin Formation near Luray, Virginia: Geological Society of America Bulletin, v. 66, no. 7, p. 871-896.

Richardson, C.A., 1982, Ground water in the Piedmont Upland of Central Maryland: U.S. Geological Survey Water-Supply Paper 2077, 42 p.

Ross, B.B., Woodward, J.E., Dillaha, T.A., Kauf, L.D., Thompson, N.R., Childs, C.C., and Worley, S.K., 1992, Evaluation of household water quality in Clarke County, Virginia: Blacksburg, VA, Department of Agricultural Engineering, Virginia Polytechnic Institute and State University, $49 \mathrm{p}$. 
Rutledge, A.T., 1993, Computer programs for describing the recession of ground-water discharge and for estimating mean ground-water recharge and discharge from streamflow records: U.S. Geological Survey Water-Resources Investigations Report 93-4121, 45 p.

Rutledge, A.T., and Mesko, T.O., 1996, Estimated hydrologic characteristics of shallow aquifer systems in the Valley and Ridge, the Blue Ridge, and the Piedmont Physiographic Provinces based on analysis of streamflow recession and base flow: U.S. Geological Survey Professional Paper 1422-B, 58 p.

Schlosser, Peter, Stute, M., Dorr, H., Sonntag, C., and Munnich, K.O., 1988, Tritium $/{ }^{3} \mathrm{He}$ dating of shallow groundwater: Earth and Planetary Science Letters, v. 89, p. 353-362.

Schlosser, Peter, Stute, M., Dorr, H., Sonntag, C., and Munnich, K.O., 1989, Tritiogenic ${ }^{3} \mathrm{He}$ in shallow groundwater: Earth and Planetary Science Letters, v. 94, p. 245-256.

Schnabel Engineering Associates, 1983, Hydraulic and engineering study, Prospect Hill Spring, Clarke County, Virginia—Report to Prospect Hill Spring Committee, Town of Berryville, Virginia: Richmond, VA, Schnabel Engineering Associates, 25 p.

Schwab, F.L., 1986, Latest Precambrian-earliest Paleozoic sedimentation, Appalachian Blue Ridge and adjacent areas-Review and speculation, in McDowell, R.C., and Glover, L., III, eds., The Lowry volume--Studies in Appalachian geology: Virginia Tech Department of Geological Sciences Memoir 3, p. 115-137.

Senior, L.A., Sloto, R.A., and Reif, A.G., 1997, Hydrogeology and water quality of the West Valley Creek Basin, Chester County, Pennsylvania: U.S. Geological Survey WaterResources Investigations Report 94-4137, 160 p.

Shultz, R.A., Hobba, W.A., Jr., and Kozar, M.D., 1995, Geohydrology, ground-water availability, and ground-water quality of Berkeley County, West Virginia, with emphasis on the carbonate-rock area: U.S. Geological Survey WaterResources Investigations Report 93-4073, 88 p.

Southworth, C.S., 1990, Hydrogeologic setting of springs on Short Hill Mountain, Loudoun County, Virginia: U.S. Geological Survey Miscellaneous Field Studies Map 2112, scale 1:24,000.

Southworth, Scott, Brezinski, D.K., Drake, A.A., Jr., Burton, W.C., Orndorff, R.C., and Froelich, A.J., 2002, Digital geologic map and database of the Frederick $30^{\prime}$ x $60^{\prime}$ quadrangle, Maryland, Virginia, and West Virginia, Version 1.0: U.S. Geological Survey Open-File Report 02-437, 79 p., 2 pls., scale 1:100,000.
Southworth, Scott, Brezinski, D.K., Drake, A.A., Jr., Burton, W.C., Orndorff, R.C., Froelich, A.J., Reddy, J.E., Denenny, Danielle, and Daniels, D.L., 2007, Geologic map of the Frederick $30^{\prime} \times 60^{\prime}$ quadrangle, Maryland, Virginia, and West Virginia: Pamphlet to accompany U.S. Geological Survey Scientific Investigations Map 2889, 42 p.

Sugisaki, R., Takeda, H., Kawabe, I., and Miyazaki, H., 1982, Simplified gas chromatographic analysis of $\mathrm{H}_{2}$, He, Ne, Ar, $\mathrm{N}_{2}$, and $\mathrm{CH}_{4}$ in subsurface gases for seismo-geochemical studies: Chemical Geology, v. 36, p. 217-226.

Swain, L.A., 1993, Hydrogeological characteristics of the bedrock aquifers in the Appalachian Valley and Ridge, Piedmont, and Blue Ridge Physiographic Provinces of the Eastern and Southeastern United States [abs.]: American Association of Petroleum Geologists Bulletin, v. 77/78, p. 1476.

Thatcher, L.L., Janzer, V.J., and Edwards, K.W., 1977, Methods for determination of radioactive substances in water and fluvial sediments: U.S. Geological Survey Techniques of Water-Resources Investigations, chap. A5, p. 79-81.

Trainer, F.W., and Watkins, F.A., Jr., 1975, Geohydrologic reconnaissance of the Upper Potomac River Basin: U.S. Geological Survey Water-Supply Paper 2035, 68 p.

Virginia Division of Mineral Resources, 2003, Digital geospatial data for the geologic map of the Virginia portion of the Winchester 30 x 60-minute quadrangle: Virginia Division of Mineral Resources Publication 171, Part B, scale 1:100,000.

Whipkey, R.Z., 1965, Subsurface stormflow from forested slopes: Bulletin of the International Association of Scientific Hydrology, v. 10, no. 2, p. 74-85.

Whitaker, J.C., 1955, Direction of current flow in some lower Cambrian clastics in Maryland: Geological Society of America Bulletin, v. 66, no. 6, p. 763-766.

Wright, W.G., 1990, Ground-water hydrology and quality in the Valley and Ridge and Blue Ridge Physiographic Provinces of Clarke County, Virginia: U.S. Geological Survey Water-Resources Investigations Report 90-4134, 61 p.

Yager, R.M., Southworth, Scott, and Voss, C.I., 2008, Simulation of ground-water flow in the Shenandoah Valley, Virginia and West Virginia, using variable-direction anisotropy in hydraulic conductivity to represent bedrock structure: U.S. Geological Survey Scientific Investigations Report 2008-5002, 54 p. 



\section{Appendixes}

1. Record of selected wells in Clarke County, Virginia .........................................................

2. Record of selected springs in Clarke County, Virginia ..................................................76

3. Water-level measurements from wells in Clarke County, Virginia, 2002-2008.................77

4. Discharge and water-quality field properties from streams and springs in Clarke County, Virginia, 2003-2008.

5. Summary of average dissolved gas compositions (nitrogen, argon, oxygen, carbon dioxide, methane, and neon), recharge temperatures, and quantities of excess air in water samples from springs in Clarke County, Virginia, 2003-2005 .....111

6. Concentrations of chlorofluorocarbons and sulfur hexafluoride in North American air, 1940-2006.

7. Summary of average chlorofluorocarbon concentrations and calculated atmospheric partial pressures in water samples from springs in Clarke County, Virginia, 2003-2005.

8. Summary of average chlorofluorocarbon-based model piston-flow apparent recharge dates, ages, and uncertainties in water samples from springs in Clarke County, Virginia, 2003-2005

9. Summary of average chlorofluorocarbon-based model ratio apparent recharge dates, ages, and uncertainties in water samples from springs in Clarke County, Virginia, 2003-2005

10. Summary of average sulfur hexafluoride data in water samples from springs in Clarke County, Virginia, 2003-2005

11. Summary of tritium, dissolved helium, and dissolved neon data in water samples from springs in Clarke County, Virginia, 2003-2005

12. Summary of apparent tritium/helium-3 ages in water samples from springs in Clarke County, Virginia, 2003-2005

13. Summary of oxygen $\left(\delta^{18} 0\right)$ and hydrogen $\left(\delta^{2} \mathrm{H}\right)$ isotopic data in water samples from springs in Clarke County, Virginia, 2003-2005 


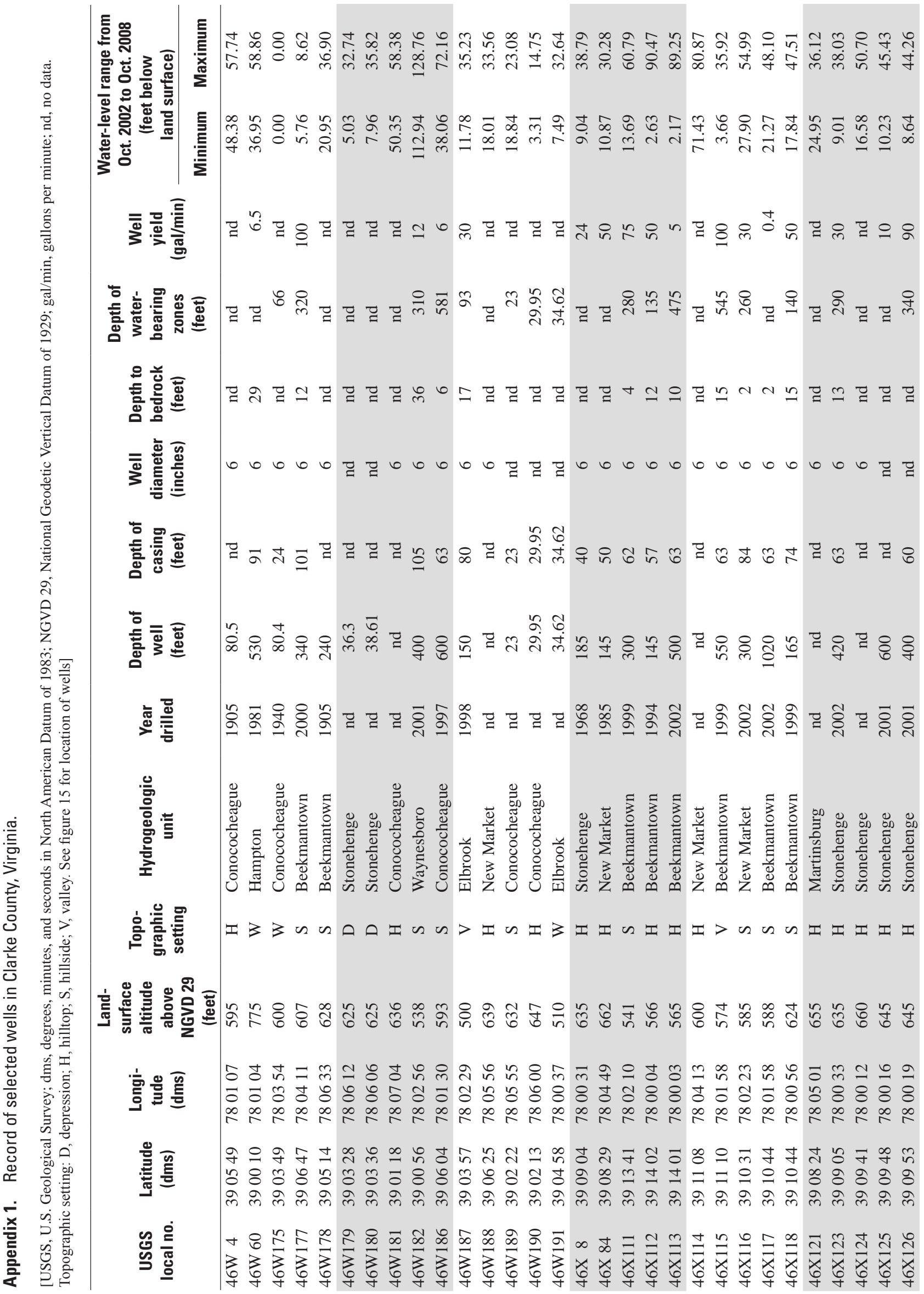




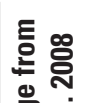

言

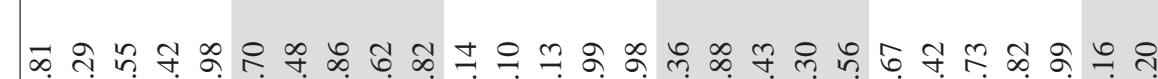
ゆ ம்

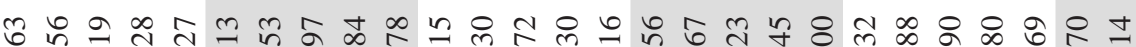
ம் மூ

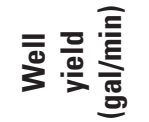

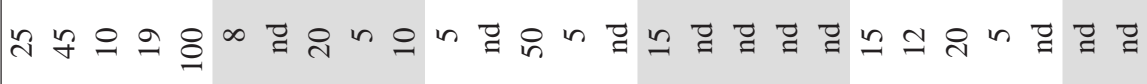

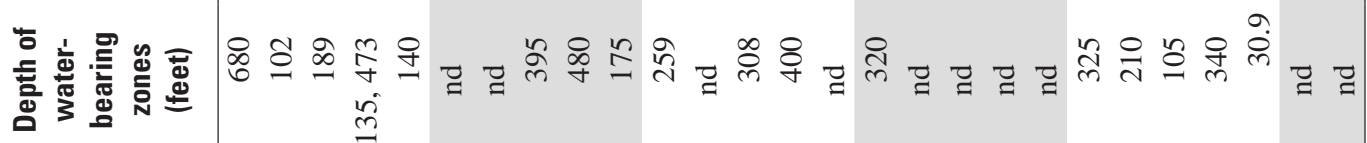

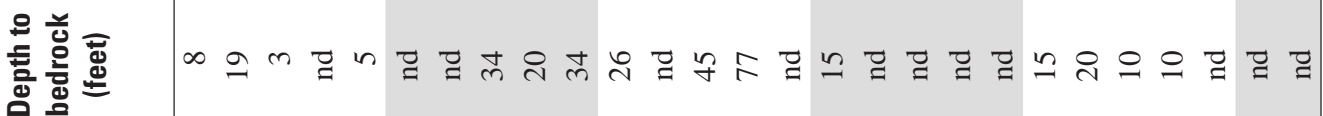
焉离离

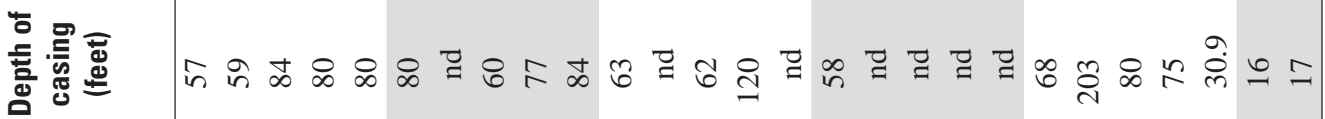
言恶离离

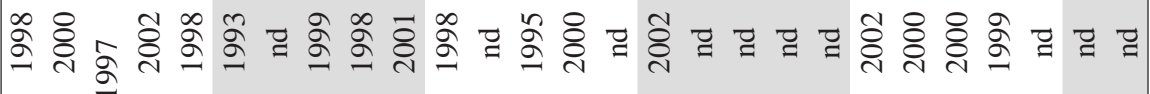

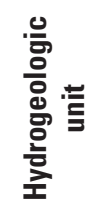

흥

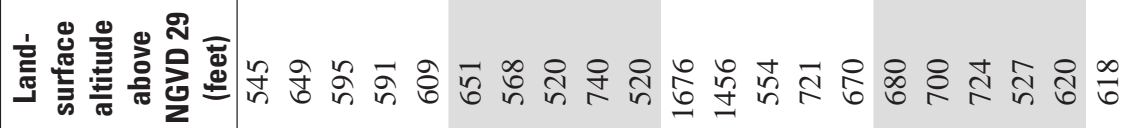

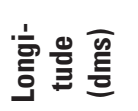

궁 냉

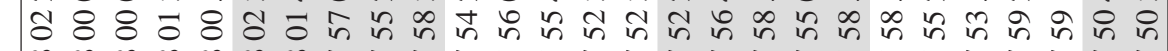

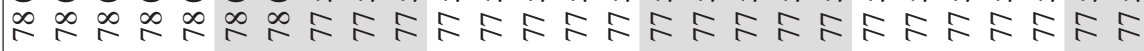
竞

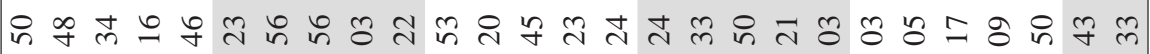

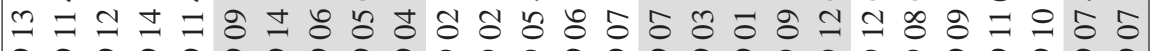

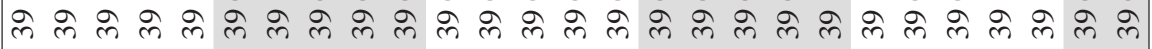


Appendix 2. Record of selected springs in Clarke County, Virginia.

[USGS, U.S. Geological Survey; dms, degrees, minutes, and seconds in North American Datum of 1983; NGVD 29, National Geodetic Vertical Datum of 1929; $\mathrm{ft}^{3} / \mathrm{s}$, cubic feet per second $\left(1 \mathrm{ft}^{3} / \mathrm{s}\right.$ equals 448.8 gallons per minute); ${ }^{\circ} \mathrm{C}$, degrees Celsius; $\mu \mathrm{S} / \mathrm{cm}$ microsiemens per centimeter; mg/L, milligrams per liter.

See figure 15 for location of springs]

\begin{tabular}{|c|c|c|c|c|c|c|c|c|c|c|c|c|c|c|}
\hline \multirow[t]{2}{*}{$\begin{array}{c}\text { USGS } \\
\text { local no. }\end{array}$} & \multirow[t]{2}{*}{$\begin{array}{l}\text { Latitude } \\
\text { (dms) }\end{array}$} & \multirow[t]{2}{*}{$\begin{array}{l}\text { Longitude } \\
\text { (dms) }\end{array}$} & \multirow{2}{*}{$\begin{array}{l}\text { Land- } \\
\text { surface } \\
\text { altitude } \\
\text { above } \\
\text { NGVD } 29 \\
\text { (feet) }\end{array}$} & \multirow[t]{2}{*}{$\begin{array}{c}\text { Hydrogeologic } \\
\text { unit }\end{array}$} & \multicolumn{2}{|c|}{$\begin{array}{c}\text { Discharge } \\
\left(\mathrm{ft}^{3} / \mathrm{s}\right)\end{array}$} & \multicolumn{2}{|c|}{$\begin{array}{c}\text { Water } \\
\text { temperature } \\
\left({ }^{\circ} \mathrm{C}\right)\end{array}$} & \multicolumn{2}{|c|}{$\begin{array}{c}\text { Specific } \\
\text { conductance } \\
\left(\mu \mathrm{S} / \mathrm{cm} \text { at } 25^{\circ} \mathrm{C}\right)\end{array}$} & \multicolumn{2}{|c|}{$\begin{array}{c}\text { Dissolved } \\
\text { oxygen } \\
\text { (mg/L) }\end{array}$} & \multicolumn{2}{|c|}{$\begin{array}{c}\mathrm{pH} \\
\text { (standard } \\
\text { units) }\end{array}$} \\
\hline & & & & & Min & Max & Min & Max & Min & Max & Min & Max & Min & Max \\
\hline 01636283 & 390004 & 780111 & 710 & Harpers & 0.0004 & 0.411 & 11.0 & nd & 21 & nd & 6.1 & nd & 6.0 & nd \\
\hline 46WS 1 & 390406 & 780141 & 470 & Conococheague & 3.63 & 9.59 & 12.5 & 13.0 & 543 & 589 & 6.7 & 7.9 & 6.8 & 7.4 \\
\hline 46WS 2 & 390652 & 780415 & 615 & Beekmantown & nd & nd & 13.6 & nd & 533 & nd & 0.9 & nd & 6.3 & nd \\
\hline 46WS 3 & 390519 & 780235 & 535 & Conococheague & 1.16 & 3.06 & 12.0 & 12.7 & 550 & 651 & 4.7 & 7.6 & 6.6 & 7.1 \\
\hline 46WS 5 & 390604 & 780313 & 557 & Beekmantown & 0 & 1.29 & 11.8 & 13.7 & 521 & 690 & 1.9 & 6.6 & 6.7 & 7.5 \\
\hline 46WS 7 & 390139 & 780557 & 570 & Conococheague & 0.74 & 1.32 & 12.5 & 12.8 & 493 & 522 & 6.6 & 7.3 & 7.0 & 7.3 \\
\hline 46WS 26 & 390122 & 780652 & 581 & Conococheague & 0.006 & 0.23 & 9.8 & 15.0 & 469 & 546 & 4.1 & 7.2 & 6.4 & 7.6 \\
\hline 46WS 27 & 390002 & 780108 & 744 & Harpers & nd & nd & 9.6 & 16.0 & 17 & 25 & 6.3 & 9.2 & 4.4 & 6.2 \\
\hline 46WS 28 & 390003 & 780111 & 715 & Harpers & nd & nd & 5.7 & 17.7 & 15 & 26 & 2.2 & 12.5 & 4.2 & 6.6 \\
\hline 46WS 29 & 390002 & 780111 & 739 & Harpers & nd & nd & 7.9 & 16.2 & 18 & 34 & 2.2 & 9.8 & 4.0 & 6.5 \\
\hline 46WS 30 & 390003 & 780112 & 731 & Harpers & nd & nd & 5.2 & 14.5 & 26 & 32 & 1.9 & 11.0 & 5.0 & 6.5 \\
\hline 46WS 32 & 390626 & 780602 & 585 & New Market & 0.06 & 0.70 & 12.6 & 12.9 & 560 & 677 & 3.1 & 10.1 & 6.7 & 7.1 \\
\hline 46WS 34 & 390158 & 780244 & 501 & Elbrook & 0.01 & 0.28 & 12.4 & 13.0 & 454 & 608 & 3.4 & 7.2 & 6.8 & 7.7 \\
\hline 46WS 35 & 390648 & 780409 & 601 & Beekmantown & 0.03 & 0.25 & 11.8 & 13.5 & 561 & 672 & 1.1 & 5.3 & 6.7 & 7.1 \\
\hline 46WS 36 & 390030 & 780055 & 620 & Harpers & 0.008 & nd & 11.7 & nd & 39 & nd & 10.9 & nd & 6.3 & nd \\
\hline 46WS 40 & 390544 & 780633 & 580 & Beekmantown & 0.14 & nd & 12.6 & nd & 629 & nd & 3.1 & nd & 7.0 & nd \\
\hline $46 S 3$ & 390812 & 780110 & 600 & Stonehenge & 0.001 & 2.27 & 11.3 & 12.5 & 577 & 706 & 3.6 & 12.3 & 6.5 & 7.2 \\
\hline 47WS 15 & 390427 & 775517 & 725 & Harpers & 0 & 0.07 & 10.7 & 13.4 & 46 & 144 & 8.3 & 10.5 & 4.8 & 6.6 \\
\hline 47XS 1 & 390839 & 775457 & 460 & Tomstown & nd & nd & nd & nd & nd & nd & nd & nd & nd & nd \\
\hline 47XS 2 & 390908 & 775603 & 494 & Elbrook & 0.17 & 2.45 & 12.0 & 12.3 & 521 & 573 & 7.1 & 9.7 & 5.7 & 7.4 \\
\hline 47XS 3 & 390843 & 775241 & 425 & Tomstown & nd & nd & 12.9 & nd & 420 & nd & 7.6 & nd & 7.2 & nd \\
\hline 47XS 6 & 391135 & 775606 & 532 & Conococheague & 0.01 & 1.92 & 9.4 & 12.7 & 510 & 587 & 6.1 & 9.3 & 6.5 & 7.6 \\
\hline 47XS 11 & 391002 & 775853 & 591 & Conococheague & nd & nd & 11.2 & 13.9 & 560 & 594 & 0.9 & 8.1 & 6.9 & 7.2 \\
\hline 47XS 21 & 391000 & 775846 & 589 & Conococheague & nd & nd & 11.4 & 14.2 & 594 & 645 & 5.6 & 7.2 & 6.8 & 7.2 \\
\hline 47XS 22 & 391000 & 775847 & 590 & Conococheague & nd & nd & 10.7 & 13.4 & 608 & 671 & 5.5 & 7.3 & 6.8 & 7.2 \\
\hline 47XS 23 & 391004 & 775848 & 600 & Conococheague & nd & nd & 11.0 & 12.6 & 597 & 632 & 6.3 & 7.7 & 6.7 & 7.3 \\
\hline 48WS 1 & 390700 & 775110 & 978 & Weverton & 0.0001 & 0.07 & 11.4 & 13.2 & 94 & 213 & 7.2 & 10.8 & 5.3 & 7.0 \\
\hline
\end{tabular}


Appendix 3. Water-level measurements from wells in Clarke County, Virginia, 2002-2008.

[ft blsd, feet below land surface datum. See figure 15 for location of wells]

\begin{tabular}{|c|c|c|c|c|c|c|}
\hline $\begin{array}{l}\text { USGS } \\
\text { local no. }\end{array}$ & $\begin{array}{l}\text { USGS } \\
\text { site no. }\end{array}$ & Date & Time & $\begin{array}{l}\text { Water level } \\
\text { (ft blsd) }\end{array}$ & $\begin{array}{c}\text { Water-level } \\
\text { status }\end{array}$ & $\begin{array}{l}\text { Measurement } \\
\text { method }\end{array}$ \\
\hline \multirow[t]{25}{*}{ 46W 4} & 390548078010801 & $10 / 24 / 2002$ & 1335 & & Dry & Steel tape \\
\hline & & 01/31/2003 & 0820 & & Dry & Steel tape \\
\hline & & $04 / 24 / 2003$ & 1430 & 54.24 & & Steel tape \\
\hline & & 07/30/2003 & 1435 & 48.38 & & Steel tape \\
\hline & & $10 / 23 / 2003$ & 1305 & 50.05 & & Steel tape \\
\hline & & $01 / 21 / 2004$ & 1605 & 49.04 & & Steel tape \\
\hline & & $04 / 05 / 2004$ & 1550 & 52.14 & & Steel tape \\
\hline & & 07/27/2004 & 1322 & 56.57 & & Steel tape \\
\hline & & $10 / 18 / 2004$ & 1546 & 57.61 & & Electric tape \\
\hline & & 01/25/2005 & 1643 & 57.74 & & Electric tape \\
\hline & & 05/02/2005 & 1709 & 55.14 & & Electric tape \\
\hline & & 07/18/2005 & 1342 & & Dry & Electric tape \\
\hline & & 10/26/2005 & 1405 & & Dry & Electric tape \\
\hline & & 01/25/2006 & 1340 & & Dry & Electric tape \\
\hline & & 04/28/2006 & 0837 & & Dry & Electric tape \\
\hline & & 07/24/2006 & 1331 & & Dry & Electric tape \\
\hline & & $10 / 24 / 2006$ & 1426 & & Dry & Electric tape \\
\hline & & 01/25/2007 & 1222 & & Dry & Electric tape \\
\hline & & 04/16/2007 & 1514 & & Dry & Electric tape \\
\hline & & 07/16/2007 & 1548 & & Dry & Steel tape \\
\hline & & $10 / 18 / 2007$ & 1350 & & Dry & Electric tape \\
\hline & & $01 / 25 / 2008$ & 1002 & & Dry & Electric tape \\
\hline & & $04 / 14 / 2008$ & 1340 & & Dry & Electric tape \\
\hline & & 07/14/2008 & 1408 & & Dry & Electric tape \\
\hline & & $10 / 20 / 2008$ & 1543 & & Dry & Electric tape \\
\hline \multirow[t]{14}{*}{ 46W 60} & 390021078005301 & $01 / 31 / 2003$ & 1230 & 50.53 & & Steel tape \\
\hline & & $04 / 22 / 2003$ & 0945 & 40.29 & & Steel tape \\
\hline & & 07/31/2003 & 1113 & 47.24 & & Steel tape \\
\hline & & $11 / 05 / 2003$ & 1330 & 46.02 & & Steel tape \\
\hline & & 02/05/2004 & 1041 & 46.20 & & Steel tape \\
\hline & & 04/13/2004 & 1212 & 36.95 & & Steel tape \\
\hline & & 07/15/2004 & 1351 & 47.63 & Recently pumped & Steel tape \\
\hline & & $10 / 25 / 2004$ & 1412 & 49.99 & & Steel tape \\
\hline & & $01 / 25 / 2005$ & 1422 & 41.60 & & Steel tape \\
\hline & & 05/04/2005 & 0949 & 46.29 & Recently pumped & Steel tape \\
\hline & & 07/21/2005 & 1349 & 48.61 & Recently pumped & Steel tape \\
\hline & & $11 / 04 / 2005$ & 1212 & 58.86 & Recently pumped & Steel tape \\
\hline & & $02 / 03 / 2006$ & 1000 & 53.20 & Recently pumped & Electric tape \\
\hline & & 05/03/2006 & 0956 & 54.53 & & Steel tape \\
\hline \multirow[t]{17}{*}{ 46W177 } & 390647078041101 & $10 / 16 / 2002$ & 1430 & 6.97 & & Steel tape \\
\hline & & $01 / 22 / 2003$ & 1505 & 6.39 & & Steel tape \\
\hline & & $04 / 18 / 2003$ & 1015 & 5.76 & & Steel tape \\
\hline & & 07/21/2003 & 1325 & 6.52 & & Steel tape \\
\hline & & $10 / 28 / 2003$ & 0935 & 6.85 & & Steel tape \\
\hline & & $01 / 22 / 2004$ & 1130 & 7.10 & & Steel tape \\
\hline & & 04/07/2004 & 1335 & 6.21 & & Steel tape \\
\hline & & $07 / 22 / 2004$ & 0957 & 7.81 & & Steel tape \\
\hline & & $10 / 21 / 2004$ & 1110 & 7.37 & & Steel tape \\
\hline & & 01/21/2005 & 1100 & 6.29 & & Electric tape \\
\hline & & 05/02/2005 & 1517 & 6.99 & & Steel tape \\
\hline & & 07/18/2005 & 1445 & 8.01 & & Steel tape \\
\hline & & $10 / 26 / 2005$ & 1244 & 7.48 & & Steel tape \\
\hline & & 01/31/2006 & 0913 & 6.50 & & Steel tape \\
\hline & & 04/26/2006 & 1643 & 7.56 & & Steel tape \\
\hline & & $07 / 24 / 2006$ & 1418 & 7.47 & & Steel tape \\
\hline & & $10 / 18 / 2006$ & 1459 & 7.11 & & Steel tape \\
\hline
\end{tabular}


78 Hydrogeology and Groundwater Availability in Clarke County, Virginia

Appendix 3. Water-level measurements from wells in Clarke County, Virginia, 2002-2008.-Continued

[ft blsd, feet below land surface datum. See figure 15 for location of wells]

\begin{tabular}{|c|c|c|c|c|c|c|}
\hline $\begin{array}{c}\text { USGS } \\
\text { local no. }\end{array}$ & $\begin{array}{l}\text { USGS } \\
\text { site no. }\end{array}$ & Date & Time & $\begin{array}{c}\text { Water level } \\
\text { (ft blsd) }\end{array}$ & $\begin{array}{c}\text { Water-level } \\
\text { status }\end{array}$ & $\begin{array}{c}\text { Measurement } \\
\text { method }\end{array}$ \\
\hline \multirow{8}{*}{\multicolumn{2}{|c|}{ 46W177 (cont.) }} & 01/23/2007 & 1132 & 6.95 & & Steel tape \\
\hline & & 04/17/2007 & 1114 & 5.98 & & Steel tape \\
\hline & & 07/16/2007 & 1342 & 8.12 & & Steel tape \\
\hline & & $10 / 17 / 2007$ & 1101 & 8.62 & & Steel tape \\
\hline & & 01/24/2008 & 1345 & 8.13 & & Steel tape \\
\hline & & 04/14/2008 & 1512 & 7.46 & & Steel tape \\
\hline & & 07/16/2008 & 0950 & 7.69 & & Steel tape \\
\hline & & $10 / 21 / 2008$ & 1124 & 8.49 & & Steel tape \\
\hline \multirow[t]{26}{*}{ 46W178 } & \multirow[t]{26}{*}{390514078063301} & $10 / 22 / 2002$ & 1145 & 29.51 & & Steel tape \\
\hline & & 01/28/2003 & 1250 & 25.76 & & Steel tape \\
\hline & & 04/23/2003 & 1545 & 20.95 & & Steel tape \\
\hline & & 07/21/2003 & 1255 & 24.15 & & Steel tape \\
\hline & & $10 / 28 / 2003$ & 1040 & 26.69 & & Steel tape \\
\hline & & 02/04/2004 & 1345 & 30.31 & & Steel tape \\
\hline & & 04/05/2004 & 1340 & 23.62 & & Steel tape \\
\hline & & 07/19/2004 & 1328 & 33.39 & & Steel tape \\
\hline & & 07/28/2004 & 1550 & 33.54 & & Steel tape \\
\hline & & $10 / 25 / 2004$ & 1504 & 31.44 & & Steel tape \\
\hline & & 01/18/2005 & 1447 & 21.98 & & Steel tape \\
\hline & & 05/02/2005 & 1420 & 27.49 & & Steel tape \\
\hline & & 07/18/2005 & 1407 & 31.12 & & Steel tape \\
\hline & & $10 / 26 / 2005$ & 1228 & 28.64 & & Steel tape \\
\hline & & 01/31/2006 & 0944 & 23.07 & & Steel tape \\
\hline & & 05/02/2006 & 0926 & 31.89 & & Steel tape \\
\hline & & 07/18/2006 & 1416 & 28.78 & & Steel tape \\
\hline & & $10 / 24 / 2006$ & 1515 & 31.42 & & Steel tape \\
\hline & & 01/30/2007 & 1113 & 30.28 & & Steel tape \\
\hline & & 04/16/2007 & 1401 & 24.85 & & Steel tape \\
\hline & & 07/19/2007 & 1117 & 34.58 & & Steel tape \\
\hline & & 10/18/2007 & 1127 & 36.90 & & Steel tape \\
\hline & & 01/24/2008 & 1308 & 32.30 & & Steel tape \\
\hline & & 04/14/2008 & 1418 & 30.00 & & Steel tape \\
\hline & & 07/14/2008 & 1613 & 31.92 & & Steel tape \\
\hline & & $10 / 20 / 2008$ & 1337 & 33.66 & & Steel tape \\
\hline \multirow[t]{22}{*}{ 46W179 } & \multirow[t]{22}{*}{390328078061201} & $10 / 23 / 2002$ & 1220 & 30.30 & & Steel tape \\
\hline & & 01/24/2003 & 1132 & 15.86 & & Steel tape \\
\hline & & 04/16/2003 & 1403 & 5.03 & & Steel tape \\
\hline & & 07/28/2003 & 1345 & 12.73 & & Steel tape \\
\hline & & $10 / 28 / 2003$ & 1115 & 13.48 & & Steel tape \\
\hline & & 01/21/2004 & 1130 & 14.66 & & Steel tape \\
\hline & & 04/06/2004 & 1355 & 12.95 & & Steel tape \\
\hline & & 07/12/2004 & 1224 & 21.36 & & Steel tape \\
\hline & & $10 / 18 / 2004$ & 1324 & 21.42 & & Steel tape \\
\hline & & 01/18/2005 & 1020 & 15.72 & & Electric tape \\
\hline & & 04/26/2005 & 1455 & 14.50 & & Steel tape \\
\hline & & 07/18/2005 & 1219 & 23.64 & & Steel tape \\
\hline & & $10 / 17 / 2005$ & 1536 & 29.44 & & Steel tape \\
\hline & & 01/23/2006 & 1452 & 20.92 & & Steel tape \\
\hline & & 04/28/2006 & 0911 & 26.27 & & Steel tape \\
\hline & & 07/17/2006 & 1506 & 22.14 & & Steel tape \\
\hline & & $10 / 23 / 2006$ & 1431 & 28.86 & & Steel tape \\
\hline & & 01/29/2007 & 1548 & 25.83 & & Steel tape \\
\hline & & 04/16/2007 & 1333 & 15.30 & & Steel tape \\
\hline & & 04/24/2007 & 1547 & 18.13 & & Steel tape \\
\hline & & 07/16/2007 & 1252 & 28.85 & & Steel tape \\
\hline & & $10 / 15 / 2007$ & 1358 & 32.74 & & Steel tape \\
\hline
\end{tabular}


Appendix 3. Water-level measurements from wells in Clarke County, Virginia, 2002-2008.-Continued

[ft blsd, feet below land surface datum. See figure 15 for location of wells]

\begin{tabular}{|c|c|c|c|c|c|c|}
\hline $\begin{array}{c}\text { USGS } \\
\text { local no. }\end{array}$ & $\begin{array}{l}\text { USGS } \\
\text { site no. }\end{array}$ & Date & Time & $\begin{array}{c}\text { Water level } \\
\text { (ft blsd) }\end{array}$ & $\begin{array}{c}\text { Water-level } \\
\text { status }\end{array}$ & $\begin{array}{c}\text { Measurement } \\
\text { method }\end{array}$ \\
\hline \multirow{4}{*}{\multicolumn{2}{|c|}{ 46W179 (cont.) }} & $01 / 25 / 2008$ & 1035 & 31.99 & & Steel tape \\
\hline & & $04 / 16 / 2008$ & 0912 & 27.46 & & Steel tape \\
\hline & & $07 / 14 / 2008$ & 1518 & 21.42 & & Steel tape \\
\hline & & $10 / 20 / 2008$ & 1416 & 28.48 & & Steel tape \\
\hline \multirow[t]{26}{*}{ 46W180 } & 390336078060601 & $10 / 23 / 2002$ & 1244 & 33.44 & & Steel tape \\
\hline & & $01 / 24 / 2003$ & 1130 & 19.02 & & Steel tape \\
\hline & & $04 / 16 / 2003$ & 1428 & 7.96 & & Steel tape \\
\hline & & 07/21/2003 & 1050 & 13.77 & & Steel tape \\
\hline & & 10/28/2003 & 1100 & 16.63 & & Steel tape \\
\hline & & $02 / 04 / 2004$ & 1055 & 20.06 & & Steel tape \\
\hline & & $04 / 05 / 2004$ & 1405 & 15.64 & & Steel tape \\
\hline & & 07/12/2004 & 1215 & 24.62 & & Steel tape \\
\hline & & $10 / 18 / 2004$ & 1301 & 24.89 & & Steel tape \\
\hline & & 01/18/2005 & 1530 & 18.80 & & Steel tape \\
\hline & & 04/26/2005 & 1416 & 17.81 & & Steel tape \\
\hline & & 07/18/2005 & 1203 & 27.24 & & Steel tape \\
\hline & & 10/17/2005 & 1524 & 33.65 & & Steel tape \\
\hline & & 01/23/2006 & 1441 & 23.72 & & Steel tape \\
\hline & & 04/28/2006 & 0900 & 29.59 & & Steel tape \\
\hline & & $07 / 17 / 2006$ & 1525 & 25.54 & & Steel tape \\
\hline & & $10 / 18 / 2006$ & 1435 & 31.48 & & Steel tape \\
\hline & & 01/23/2007 & 1234 & 28.23 & & Steel tape \\
\hline & & 04/16/2007 & 1321 & 18.56 & & Steel tape \\
\hline & & 07/16/2007 & 1316 & 32.24 & & Steel tape \\
\hline & & 07/16/2007 & 1448 & 32.25 & & Steel tape \\
\hline & & $10 / 15 / 2007$ & 1425 & 35.82 & & Steel tape \\
\hline & & 01/24/2008 & 1224 & 34.94 & & Steel tape \\
\hline & & $04 / 14 / 2008$ & 1358 & 30.14 & & Steel tape \\
\hline & & $07 / 14 / 2008$ & 1507 & 24.80 & & Steel tape \\
\hline & & $10 / 20 / 2008$ & 1351 & 31.78 & & Steel tape \\
\hline \multirow[t]{25}{*}{ 46W181 } & 390118078070401 & $10 / 25 / 2002$ & 1400 & 58.38 & & Steel tape \\
\hline & & 01/31/2003 & 1425 & 52.55 & & Steel tape \\
\hline & & 04/21/2003 & 1458 & 50.35 & & Steel tape \\
\hline & & 07/30/2003 & 1045 & 50.61 & & Steel tape \\
\hline & & $10 / 28 / 2003$ & 1330 & 50.39 & & Steel tape \\
\hline & & 02/04/2004 & 1310 & 51.34 & & Steel tape \\
\hline & & 04/07/2004 & 0922 & 52.63 & & Steel tape \\
\hline & & $07 / 12 / 2004$ & 1314 & 53.49 & Recently pumped & Steel tape \\
\hline & & $10 / 18 / 2004$ & 1350 & 55.33 & & Steel tape \\
\hline & & 01/26/2005 & 1115 & 54.85 & & Electric tape \\
\hline & & 04/27/2005 & 1458 & 53.37 & Recently pumped & Electric tape \\
\hline & & 07/18/2005 & 1402 & 55.31 & Recently pumped & Electric tape \\
\hline & & $10 / 20 / 2005$ & 0903 & 56.59 & & Steel tape \\
\hline & & 01/31/2006 & 1019 & 56.65 & Recently pumped & Electric tape \\
\hline & & 04/27/2006 & 1555 & 57.10 & & Electric tape \\
\hline & & 07/18/2006 & 0801 & 57.62 & & Electric tape \\
\hline & & $11 / 02 / 2006$ & 1306 & 57.69 & Recently pumped & Electric tape \\
\hline & & 01/30/2007 & 1342 & 57.65 & Recently pumped & Electric tape \\
\hline & & 04/23/2007 & 1335 & 54.88 & Recently pumped & Electric tape \\
\hline & & 07/18/2007 & 0955 & 57.29 & & Electric tape \\
\hline & & $10 / 26 / 2007$ & 1200 & 57.68 & Recently pumped & Electric tape \\
\hline & & 01/31/2008 & 1043 & 58.23 & Recently pumped & Electric tape \\
\hline & & 04/21/2008 & 1425 & 57.81 & Recently pumped & Electric tape \\
\hline & & 07/18/2008 & 0939 & 56.11 & Recently pumped & Electric tape \\
\hline & & $10 / 24 / 2008$ & 1036 & 57.38 & & Electric tape \\
\hline
\end{tabular}


Appendix 3. Water-level measurements from wells in Clarke County, Virginia, 2002-2008._Continued

[ft blsd, feet below land surface datum. See figure 15 for location of wells]

\begin{tabular}{|c|c|c|c|c|c|c|}
\hline $\begin{array}{c}\text { USGS } \\
\text { local no. }\end{array}$ & $\begin{array}{l}\text { USGS } \\
\text { site no. }\end{array}$ & Date & Time & $\begin{array}{c}\text { Water level } \\
\text { (ft blsd) }\end{array}$ & $\begin{array}{c}\text { Water-level } \\
\text { status }\end{array}$ & $\begin{array}{c}\text { Measurement } \\
\text { method }\end{array}$ \\
\hline \multirow[t]{25}{*}{ 46W182 } & 390056078025601 & $10 / 23 / 2002$ & 1325 & 119.52 & & Steel tape \\
\hline & & $01 / 22 / 2003$ & 0925 & 117.29 & & Steel tape \\
\hline & & $04 / 22 / 2003$ & 1015 & 112.94 & & Steel tape \\
\hline & & $07 / 22 / 2003$ & 0840 & 114.57 & & Steel tape \\
\hline & & $10 / 20 / 2003$ & 1540 & 114.74 & & Steel tape \\
\hline & & $01 / 21 / 2004$ & 1025 & 114.77 & & Steel tape \\
\hline & & 04/05/2004 & 1210 & 115.15 & & Steel tape \\
\hline & & 07/19/2004 & 1144 & 116.96 & & Steel tape \\
\hline & & $10 / 18 / 2004$ & 1226 & 116.74 & & Steel tape \\
\hline & & 01/18/2005 & 1333 & 115.81 & & Steel tape \\
\hline & & 05/02/2005 & 1325 & 115.64 & & Steel tape \\
\hline & & 07/18/2005 & 1229 & 117.43 & & Steel tape \\
\hline & & $10 / 17 / 2005$ & 1328 & 118.61 & & Steel tape \\
\hline & & 01/23/2006 & 1305 & 116.09 & & Steel tape \\
\hline & & 05/01/2006 & 1224 & 117.70 & & Steel tape \\
\hline & & 07/17/2006 & 1411 & 118.26 & & Steel tape \\
\hline & & $10 / 18 / 2006$ & 1317 & 117.85 & & Steel tape \\
\hline & & 01/31/2007 & 1206 & 117.78 & & Steel tape \\
\hline & & 04/16/2007 & 1248 & 115.25 & & Steel tape \\
\hline & & 07/16/2007 & 1314 & 123.50 & & Steel tape \\
\hline & & $10 / 26 / 2007$ & 1126 & 125.81 & & Steel tape \\
\hline & & $01 / 22 / 2008$ & 1237 & 128.76 & & Steel tape \\
\hline & & $04 / 14 / 2008$ & 1235 & 118.27 & & Steel tape \\
\hline & & 07/14/2008 & 1143 & 127.07 & & Steel tape \\
\hline & & $10 / 20 / 2008$ & 1307 & 123.75 & & Steel tape \\
\hline \multirow[t]{8}{*}{ 46W186 } & 390604078013001 & $10 / 23 / 2002$ & 1110 & 72.16 & & Steel tape \\
\hline & & 01/31/2003 & 0920 & 60.23 & & Steel tape \\
\hline & & $04 / 24 / 2003$ & 1415 & 45.74 & & Steel tape \\
\hline & & 07/21/2003 & 1355 & 38.06 & & Steel tape \\
\hline & & $10 / 23 / 2003$ & 1240 & 40.29 & & Steel tape \\
\hline & & $01 / 22 / 2004$ & 1350 & 40.40 & & Steel tape \\
\hline & & 04/05/2004 & 1525 & 41.84 & & Steel tape \\
\hline & & 07/27/2004 & 1258 & 52.21 & & Steel tape \\
\hline \multirow[t]{25}{*}{ 46W187 } & 390357078022901 & $10 / 23 / 2002$ & 1135 & 35.23 & & Steel tape \\
\hline & & 01/31/2003 & 0950 & 31.10 & & Steel tape \\
\hline & & $04 / 24 / 2003$ & 1335 & 20.91 & & Steel tape \\
\hline & & 07/21/2003 & 1225 & 11.78 & & Steel tape \\
\hline & & $10 / 20 / 2003$ & 1610 & 13.53 & & Steel tape \\
\hline & & $01 / 22 / 2004$ & 1310 & 15.35 & & Steel tape \\
\hline & & 04/05/2004 & 1435 & 19.38 & & Steel tape \\
\hline & & 07/19/2004 & 1235 & 27.51 & & Steel tape \\
\hline & & $10 / 18 / 2004$ & 1447 & 29.47 & & Steel tape \\
\hline & & 01/18/2005 & 1426 & 28.10 & & Steel tape \\
\hline & & 05/02/2005 & 1351 & 25.59 & & Steel tape \\
\hline & & 07/18/2005 & 1302 & 29.62 & & Steel tape \\
\hline & & $10 / 17 / 2005$ & 1500 & 32.81 & & Steel tape \\
\hline & & 01/23/2006 & 1351 & 30.85 & & Steel tape \\
\hline & & 05/01/2006 & 1255 & 32.93 & & Steel tape \\
\hline & & 07/24/2006 & 1308 & 33.34 & & Steel tape \\
\hline & & $10 / 18 / 2006$ & 1342 & 33.74 & & Steel tape \\
\hline & & 01/22/2007 & 1423 & 32.17 & & Steel tape \\
\hline & & 04/16/2007 & 1427 & 29.51 & & Steel tape \\
\hline & & 07/16/2007 & 1423 & 33.08 & & Steel tape \\
\hline & & $10 / 18 / 2007$ & 1216 & 34.43 & & Steel tape \\
\hline & & $01 / 22 / 2008$ & 1306 & 35.18 & & Steel tape \\
\hline & & 04/14/2008 & 1306 & 34.38 & & Steel tape \\
\hline & & 07/14/2008 & 1210 & 31.65 & & Steel tape \\
\hline & & $10 / 20 / 2008$ & 1454 & 32.63 & & Steel tape \\
\hline
\end{tabular}


Appendix 3. Water-level measurements from wells in Clarke County, Virginia, 2002-2008.-Continued

[ft blsd, feet below land surface datum. See figure 15 for location of wells]

\begin{tabular}{|c|c|c|c|c|c|c|}
\hline $\begin{array}{c}\text { USGS } \\
\text { local no. }\end{array}$ & $\begin{array}{l}\text { USGS } \\
\text { site no. }\end{array}$ & Date & Time & $\begin{array}{c}\text { Water level } \\
\text { (ft blsd) }\end{array}$ & $\begin{array}{c}\text { Water-level } \\
\text { status }\end{array}$ & $\begin{array}{c}\text { Measurement } \\
\text { method }\end{array}$ \\
\hline \multirow[t]{25}{*}{ 46W188 } & 390625078055601 & 10/16/2002 & 1630 & 30.74 & & Steel tape \\
\hline & & 01/22/2003 & 1440 & 22.39 & & Steel tape \\
\hline & & 04/18/2003 & 1035 & 18.01 & & Steel tape \\
\hline & & 07/30/2003 & 1410 & 22.09 & & Steel tape \\
\hline & & 10/28/2003 & 1005 & 25.60 & & Steel tape \\
\hline & & 02/04/2004 & 1415 & 24.19 & & Steel tape \\
\hline & & 04/07/2004 & 1300 & 23.28 & & Steel tape \\
\hline & & 07/15/2004 & 1129 & 30.49 & Recently pumped & Steel tape \\
\hline & & $10 / 21 / 2004$ & 1225 & 27.51 & & Steel tape \\
\hline & & 01/18/2005 & 1512 & 25.34 & & Steel tape \\
\hline & & 05/02/2005 & 1445 & 24.23 & & Steel tape \\
\hline & & 07/18/2005 & 1425 & 28.61 & & Steel tape \\
\hline & & 10/26/2005 & 1131 & 31.57 & & Steel tape \\
\hline & & 01/31/2006 & 0929 & 27.08 & & Steel tape \\
\hline & & 04/27/2006 & 1524 & 29.66 & & Steel tape \\
\hline & & 07/24/2006 & 1359 & 31.28 & & Steel tape \\
\hline & & $10 / 25 / 2006$ & 1552 & 29.09 & & Steel tape \\
\hline & & $01 / 24 / 2007$ & 1443 & 26.81 & & Steel tape \\
\hline & & 04/17/2007 & 1322 & 25.29 & & Steel tape \\
\hline & & 07/19/2007 & 1051 & 32.08 & & Steel tape \\
\hline & & $10 / 18 / 2007$ & 1006 & 33.56 & & Steel tape \\
\hline & & 01/24/2008 & 1324 & 31.38 & & Steel tape \\
\hline & & 04/14/2008 & 1454 & 29.72 & & Steel tape \\
\hline & & 07/16/2008 & 1010 & 27.79 & & Steel tape \\
\hline & & $10 / 21 / 2008$ & 1106 & 32.71 & & Steel tape \\
\hline \multirow[t]{17}{*}{ 46W189 } & 390222078055501 & $10 / 21 / 2004$ & 1350 & 19.58 & & Steel tape \\
\hline & & 01/26/2005 & 1415 & 18.84 & & Electric tape \\
\hline & & 05/04/2005 & 1521 & 18.89 & & Steel tape \\
\hline & & 07/18/2005 & 1508 & 21.80 & & Steel tape \\
\hline & & 10/20/2005 & 1620 & 23.08 & & Electric tape \\
\hline & & 01/31/2006 & 1058 & 22.70 & & Electric tape \\
\hline & & 05/02/2006 & 0946 & & Dry & Steel tape \\
\hline & & 07/17/2006 & 1439 & 22.73 & & Electric tape \\
\hline & & $11 / 02 / 2006$ & 1449 & 22.19 & & Electric tape \\
\hline & & 01/30/2007 & 1138 & & Dry & Electric tape \\
\hline & & 04/24/2007 & 1322 & 21.75 & & Steel tape \\
\hline & & 08/03/2007 & 1114 & & Dry & Electric tape \\
\hline & & $10 / 19 / 2007$ & 1149 & & Dry & Electric tape \\
\hline & & 01/31/2008 & 1141 & & Dry & Electric tape \\
\hline & & 04/21/2008 & 1513 & 20.33 & & Steel tape \\
\hline & & 07/18/2008 & 1024 & 22.75 & & Electric tape \\
\hline & & $10 / 24 / 2008$ & 1115 & & Dry & Electric tape \\
\hline \multirow[t]{17}{*}{ 46W190 } & 390213078060001 & $10 / 21 / 2004$ & 1415 & 8.14 & & Steel tape \\
\hline & & 01/26/2005 & 1417 & 3.55 & & Electric tape \\
\hline & & 05/04/2005 & 1512 & 6.74 & & Steel tape \\
\hline & & 07/18/2005 & 1518 & 12.10 & & Steel tape \\
\hline & & $10 / 20 / 2005$ & 1604 & 14.30 & & Steel tape \\
\hline & & 01/31/2006 & 1106 & 3.31 & & Steel tape \\
\hline & & 05/02/2006 & 0954 & 9.85 & & Steel tape \\
\hline & & 07/17/2006 & 1449 & 8.10 & & Steel tape \\
\hline & & $11 / 02 / 2006$ & 1513 & 9.55 & & Steel tape \\
\hline & & 01/30/2007 & 1146 & 6.47 & & Steel tape \\
\hline & & 04/24/2007 & 1410 & 6.49 & & Steel tape \\
\hline & & 08/03/2007 & 1104 & 13.40 & & Steel tape \\
\hline & & 10/19/2007 & 1138 & 14.75 & & Steel tape \\
\hline & & 01/31/2008 & 1133 & 10.86 & & Steel tape \\
\hline & & 04/21/2008 & 1526 & 3.72 & & Steel tape \\
\hline & & 07/18/2008 & 1014 & 8.89 & & Steel tape \\
\hline & & $10 / 24 / 2008$ & 1113 & 11.28 & & Steel tape \\
\hline
\end{tabular}




\section{Hydrogeology and Groundwater Availability in Clarke County, Virginia}

Appendix 3. Water-level measurements from wells in Clarke County, Virginia, 2002-2008.-Continued

[ft blsd, feet below land surface datum. See figure 15 for location of wells]

\begin{tabular}{|c|c|c|c|c|c|c|}
\hline $\begin{array}{c}\text { USGS } \\
\text { local no. }\end{array}$ & $\begin{array}{l}\text { USGS } \\
\text { site no. }\end{array}$ & Date & Time & $\begin{array}{c}\text { Water level } \\
\text { (ft blsd) }\end{array}$ & $\begin{array}{c}\text { Water-level } \\
\text { status }\end{array}$ & $\begin{array}{c}\text { Measurement } \\
\text { method }\end{array}$ \\
\hline \multirow[t]{17}{*}{ 46W191 } & 390458078003701 & $10 / 21 / 2004$ & 1502 & 19.40 & & Steel tape \\
\hline & & $01 / 25 / 2005$ & 1620 & 15.30 & & Steel tape \\
\hline & & $05 / 02 / 2005$ & 1645 & 7.49 & & Steel tape \\
\hline & & 07/18/2005 & 1323 & 16.04 & & Steel tape \\
\hline & & $10 / 20 / 2005$ & 1408 & 24.40 & & Steel tape \\
\hline & & $01 / 25 / 2006$ & 1320 & 18.60 & & Steel tape \\
\hline & & $05 / 01 / 2006$ & 1312 & 22.58 & & Steel tape \\
\hline & & 07/19/2006 & 1212 & 27.18 & & Steel tape \\
\hline & & $10 / 24 / 2006$ & 1439 & 29.02 & & Steel tape \\
\hline & & $01 / 25 / 2007$ & 1235 & 20.21 & & Steel tape \\
\hline & & $04 / 16 / 2007$ & 1455 & 12.04 & & Steel tape \\
\hline & & 07/16/2007 & 1530 & 22.62 & & Steel tape \\
\hline & & $10 / 18 / 2007$ & 1336 & 30.08 & & Steel tape \\
\hline & & $01 / 22 / 2008$ & 1407 & 32.64 & & Steel tape \\
\hline & & $04 / 14 / 2008$ & 1325 & 30.73 & & Steel tape \\
\hline & & 07/18/2008 & 1051 & 17.62 & & Steel tape \\
\hline & & $10 / 20 / 2008$ & 1527 & 26.12 & & Steel tape \\
\hline \multirow[t]{23}{*}{$46 \mathrm{X} 8$} & 390900078003401 & $10 / 21 / 2002$ & 1410 & 37.85 & & Steel tape \\
\hline & & 04/16/2003 & 1140 & 9.04 & & Steel tape \\
\hline & & $07 / 21 / 2003$ & 1430 & 12.67 & & Steel tape \\
\hline & & $10 / 22 / 2003$ & 0935 & 20.59 & & Steel tape \\
\hline & & 04/07/2004 & 1020 & 16.01 & & Steel tape \\
\hline & & 07/27/2004 & 1356 & 21.89 & & Steel tape \\
\hline & & $10 / 21 / 2004$ & 1046 & 25.42 & & Steel tape \\
\hline & & 01/20/2005 & 1209 & 23.48 & & Steel tape \\
\hline & & 05/06/2005 & 1056 & 20.05 & & Steel tape \\
\hline & & 07/21/2005 & 1310 & 27.15 & & Steel tape \\
\hline & & $10 / 26 / 2005$ & 1152 & 33.04 & & Steel tape \\
\hline & & $01 / 25 / 2006$ & 1208 & 27.81 & & Steel tape \\
\hline & & $05 / 02 / 2006$ & 1049 & 32.54 & & Steel tape \\
\hline & & 07/20/2006 & 0918 & 28.82 & & Steel tape \\
\hline & & $10 / 20 / 2006$ & 1142 & 32.57 & & Steel tape \\
\hline & & $01 / 24 / 2007$ & 1227 & 28.19 & & Steel tape \\
\hline & & 04/18/2007 & 1021 & 21.70 & & Steel tape \\
\hline & & 07/19/2007 & 1518 & 30.75 & & Steel tape \\
\hline & & $10 / 19 / 2007$ & 1104 & 38.79 & & Steel tape \\
\hline & & $01 / 24 / 2008$ & 1127 & 38.15 & & Steel tape \\
\hline & & $04 / 17 / 2008$ & 1056 & 32.39 & & Steel tape \\
\hline & & 07/16/2008 & 1108 & 24.71 & & Steel tape \\
\hline & & $10 / 23 / 2008$ & 1233 & 34.25 & & Steel tape \\
\hline \multirow[t]{16}{*}{$46 \times 84$} & 390826078050801 & $10 / 23 / 2002$ & 1035 & 29.14 & & Steel tape \\
\hline & & $01 / 28 / 2003$ & 1500 & 15.57 & & Steel tape \\
\hline & & $04 / 18 / 2003$ & 0930 & 10.87 & & Steel tape \\
\hline & & $07 / 24 / 2003$ & 0915 & 13.05 & & Steel tape \\
\hline & & $10 / 28 / 2003$ & 0845 & 16.68 & & Steel tape \\
\hline & & 04/07/2004 & 0910 & 11.10 & & Steel tape \\
\hline & & 07/28/2004 & 0933 & 19.72 & & Steel tape \\
\hline & & $10 / 22 / 2004$ & 0934 & 19.87 & & Steel tape \\
\hline & & 01/27/2005 & 0930 & 14.38 & & Steel tape \\
\hline & & 05/06/2005 & 0908 & 15.64 & & Steel tape \\
\hline & & 07/22/2005 & 0926 & 21.00 & & Steel tape \\
\hline & & 10/26/2005 & 1006 & 26.93 & & Steel tape \\
\hline & & $01 / 25 / 2006$ & 1119 & 16.78 & & Steel tape \\
\hline & & 05/02/2006 & 0901 & 20.73 & & Steel tape \\
\hline & & 07/20/2006 & 0822 & 21.70 & & Steel tape \\
\hline & & $10 / 25 / 2006$ & 0936 & 22.16 & & Steel tape \\
\hline
\end{tabular}


Appendix 3. Water-level measurements from wells in Clarke County, Virginia, 2002-2008.-Continued

[ft blsd, feet below land surface datum. See figure 15 for location of wells]

\begin{tabular}{|c|c|c|c|c|c|c|}
\hline $\begin{array}{c}\text { USGS } \\
\text { local no. }\end{array}$ & $\begin{array}{l}\text { USGS } \\
\text { site no. }\end{array}$ & Date & Time & $\begin{array}{c}\text { Water level } \\
\text { (ft blsd) }\end{array}$ & $\begin{array}{c}\text { Water-level } \\
\text { status }\end{array}$ & $\begin{array}{c}\text { Measurement } \\
\text { method }\end{array}$ \\
\hline \multirow{8}{*}{\multicolumn{2}{|c|}{$46 \mathrm{X} 84$ (cont.) }} & 01/30/2007 & 1046 & 16.90 & & Steel tape \\
\hline & & 04/24/2007 & 1003 & 14.40 & & Steel tape \\
\hline & & 07/19/2007 & 0953 & 23.78 & & Steel tape \\
\hline & & $10 / 18 / 2007$ & 0941 & 29.63 & & Steel tape \\
\hline & & 01/24/2008 & 1013 & 30.28 & & Steel tape \\
\hline & & 04/17/2008 & 0929 & 22.15 & & Steel tape \\
\hline & & 07/16/2008 & 0912 & 19.31 & & Steel tape \\
\hline & & $10 / 22 / 2008$ & 1019 & 28.20 & & Steel tape \\
\hline \multirow[t]{26}{*}{ 46X111 } & 391341078021001 & $10 / 21 / 2002$ & 1705 & 46.63 & & Steel tape \\
\hline & & 01/30/2003 & 1505 & 19.71 & & Steel tape \\
\hline & & 04/17/2003 & 1415 & 13.69 & & Steel tape \\
\hline & & 07/24/2003 & 1130 & 19.25 & & Steel tape \\
\hline & & $10 / 22 / 2003$ & 1315 & 31.60 & & Steel tape \\
\hline & & 02/04/2004 & 1605 & 29.08 & & Steel tape \\
\hline & & 04/07/2004 & 1420 & 21.10 & & Steel tape \\
\hline & & 07/28/2004 & 1129 & 17.79 & & Steel tape \\
\hline & & $10 / 20 / 2004$ & 1554 & 21.12 & & Steel tape \\
\hline & & 01/20/2005 & 1450 & 23.99 & & Steel tape \\
\hline & & 05/06/2005 & 1004 & 25.27 & & Steel tape \\
\hline & & 07/20/2005 & 1505 & 51.16 & & Steel tape \\
\hline & & 07/28/2005 & 1117 & 52.27 & & Steel tape \\
\hline & & $10 / 26 / 2005$ & 1442 & 55.00 & & Steel tape \\
\hline & & 01/27/2006 & 0942 & 24.33 & & Steel tape \\
\hline & & 05/04/2006 & 1424 & 51.18 & & Steel tape \\
\hline & & 07/24/2006 & 1454 & 40.09 & & Steel tape \\
\hline & & $11 / 03 / 2006$ & 1000 & 45.75 & & Steel tape \\
\hline & & 01/24/2007 & 1451 & 32.53 & & Steel tape \\
\hline & & 04/24/2007 & 1200 & 18.58 & & Steel tape \\
\hline & & 07/18/2007 & 1555 & 53.07 & & Steel tape \\
\hline & & 10/19/2007 & 0931 & 60.79 & & Steel tape \\
\hline & & 01/22/2008 & 1518 & 54.03 & & Steel tape \\
\hline & & 04/17/2008 & 1603 & 36.19 & & Steel tape \\
\hline & & 07/17/2008 & 1156 & 36.36 & & Steel tape \\
\hline & & $10 / 22 / 2008$ & 1523 & 57.48 & & Steel tape \\
\hline \multirow[t]{22}{*}{ 46X112 } & 391402078000401 & $10 / 17 / 2002$ & 1310 & 51.93 & & Steel tape \\
\hline & & 01/23/2003 & 1345 & 14.50 & & Steel tape \\
\hline & & 04/17/2003 & 1255 & 2.63 & & Steel tape \\
\hline & & 07/23/2003 & 1010 & 8.32 & & Steel tape \\
\hline & & $10 / 22 / 2003$ & 1230 & 13.05 & & Steel tape \\
\hline & & 02/05/2004 & 1330 & 12.77 & & Steel tape \\
\hline & & 04/07/2004 & 1345 & 3.67 & & Steel tape \\
\hline & & 07/28/2004 & 1045 & 4.80 & & Steel tape \\
\hline & & $10 / 21 / 2004$ & 0953 & 11.11 & & Steel tape \\
\hline & & 01/20/2005 & 1416 & 9.48 & & Steel tape \\
\hline & & 05/04/2005 & 1357 & 10.69 & & Steel tape \\
\hline & & 07/20/2005 & 1432 & 28.97 & & Steel tape \\
\hline & & $10 / 25 / 2005$ & 1047 & 71.21 & & Steel tape \\
\hline & & 01/26/2006 & 1334 & 29.33 & & Steel tape \\
\hline & & 05/02/2006 & 1157 & 46.11 & & Steel tape \\
\hline & & 07/20/2006 & 1231 & 37.75 & & Steel tape \\
\hline & & $10 / 20 / 2006$ & 1041 & 50.01 & & Steel tape \\
\hline & & 01/24/2007 & 1432 & 29.06 & & Steel tape \\
\hline & & 04/19/2007 & 1126 & 9.68 & & Steel tape \\
\hline & & 07/18/2007 & 1341 & 33.75 & & Steel tape \\
\hline & & $10 / 19 / 2007$ & 1030 & 87.22 & & Steel tape \\
\hline & & $11 / 08 / 2007$ & 1307 & 90.47 & & Steel tape \\
\hline
\end{tabular}


84 Hydrogeology and Groundwater Availability in Clarke County, Virginia

Appendix 3. Water-level measurements from wells in Clarke County, Virginia, 2002-2008.-Continued

[ft blsd, feet below land surface datum. See figure 15 for location of wells]

\begin{tabular}{|c|c|c|c|c|c|c|}
\hline $\begin{array}{l}\text { USGS } \\
\text { local no. }\end{array}$ & $\begin{array}{l}\text { USGS } \\
\text { site no. }\end{array}$ & Date & Time & $\begin{array}{c}\text { Water level } \\
\text { (ft blsd) }\end{array}$ & $\begin{array}{c}\text { Water-level } \\
\text { status }\end{array}$ & $\begin{array}{l}\text { Measurement } \\
\text { method }\end{array}$ \\
\hline \multirow{7}{*}{\multicolumn{2}{|c|}{$46 X 112$ (cont.) }} & $01 / 22 / 2008$ & 1455 & 80.13 & & Steel tape \\
\hline & & 02/21/2008 & 1304 & 58.98 & & Steel tape \\
\hline & & 04/17/2008 & 1501 & 37.97 & & Steel tape \\
\hline & & 05/08/2008 & 1637 & 14.13 & & Steel tape \\
\hline & & 07/17/2008 & 1132 & 20.58 & & Steel tape \\
\hline & & 07/31/2008 & 1635 & 24.47 & & Steel tape \\
\hline & & $10 / 22 / 2008$ & 1452 & 60.22 & & Steel tape \\
\hline \multirow[t]{29}{*}{$46 X 113$} & \multirow[t]{29}{*}{391401078000301} & $10 / 17 / 2002$ & 1300 & 51.45 & & Steel tape \\
\hline & & 01/23/2003 & 1350 & 14.07 & & Steel tape \\
\hline & & 04/17/2003 & 1305 & 2.17 & & Steel tape \\
\hline & & 07/23/2003 & 1020 & 7.86 & & Steel tape \\
\hline & & $10 / 22 / 2003$ & 1245 & 12.60 & & Steel tape \\
\hline & & $02 / 05 / 2004$ & 1340 & 12.30 & & Steel tape \\
\hline & & 04/07/2004 & 1355 & 3.21 & & Steel tape \\
\hline & & 07/28/2004 & 1055 & 4.32 & & Steel tape \\
\hline & & $10 / 21 / 2004$ & 0957 & 10.65 & & Steel tape \\
\hline & & 01/20/2005 & 1430 & 9.02 & & Steel tape \\
\hline & & 05/04/2005 & 1413 & 10.26 & & Steel tape \\
\hline & & 07/20/2005 & 1444 & 28.40 & & Steel tape \\
\hline & & $10 / 25 / 2005$ & 1110 & 63.82 & & Steel tape \\
\hline & & 01/26/2006 & 1338 & 28.77 & & Steel tape \\
\hline & & 05/02/2006 & 1204 & 45.21 & & Steel tape \\
\hline & & 07/20/2006 & 1237 & 37.07 & & Steel tape \\
\hline & & $10 / 20 / 2006$ & 1043 & 49.21 & & Steel tape \\
\hline & & 01/24/2007 & 1434 & 28.46 & & Steel tape \\
\hline & & 04/19/2007 & 1144 & 9.22 & & Steel tape \\
\hline & & 07/18/2007 & 1345 & 33.03 & & Steel tape \\
\hline & & $10 / 19 / 2007$ & 1033 & 86.20 & & Steel tape \\
\hline & & $11 / 08 / 2007$ & 1310 & 89.25 & & Steel tape \\
\hline & & 01/22/2008 & 1458 & 77.85 & & Steel tape \\
\hline & & 02/21/2008 & 1308 & 57.94 & & Steel tape \\
\hline & & 04/17/2008 & 1504 & 37.26 & & Steel tape \\
\hline & & 05/08/2008 & 1639 & 13.67 & & Steel tape \\
\hline & & 07/17/2008 & 1134 & 20.14 & & Steel tape \\
\hline & & 07/31/2008 & 1637 & 24.02 & & Steel tape \\
\hline & & $10 / 22 / 2008$ & 1502 & 58.74 & & Steel tape \\
\hline \multirow[t]{18}{*}{$46 \times 114$} & \multirow[t]{18}{*}{391108078041301} & $10 / 17 / 2002$ & 1500 & 80.87 & & Steel tape \\
\hline & & 01/30/2003 & 1545 & 75.45 & & Steel tape \\
\hline & & $04 / 17 / 2003$ & 1505 & 71.43 & & Steel tape \\
\hline & & 07/21/2003 & 1515 & 78.98 & & Steel tape \\
\hline & & $10 / 21 / 2003$ & 1615 & 77.97 & & Steel tape \\
\hline & & $01 / 22 / 2004$ & 1550 & 76.12 & & Steel tape \\
\hline & & 04/05/2004 & 1640 & 75.15 & & Steel tape \\
\hline & & 07/20/2004 & 0903 & 76.15 & & Steel tape \\
\hline & & $10 / 21 / 2004$ & 0910 & 76.01 & & Steel tape \\
\hline & & 01/21/2005 & 0932 & 75.45 & & Steel tape \\
\hline & & 05/04/2005 & 1055 & 76.43 & & Steel tape \\
\hline & & 07/20/2005 & 1242 & 78.90 & & Steel tape \\
\hline & & $10 / 28 / 2005$ & 0908 & 80.39 & & Steel tape \\
\hline & & 01/27/2006 & 1013 & 73.86 & & Steel tape \\
\hline & & 05/04/2006 & 1259 & 78.40 & & Steel tape \\
\hline & & $11 / 03 / 2006$ & 1032 & 77.04 & & Steel tape \\
\hline & & 01/25/2007 & 1011 & 76.63 & & Steel tape \\
\hline & & 04/27/2007 & 1439 & 74.38 & & Steel tape \\
\hline
\end{tabular}


Appendix 3. Water-level measurements from wells in Clarke County, Virginia, 2002-2008.-Continued

[ft blsd, feet below land surface datum. See figure 15 for location of wells]

\begin{tabular}{|c|c|c|c|c|c|c|}
\hline $\begin{array}{c}\text { USGS } \\
\text { local no. }\end{array}$ & $\begin{array}{c}\text { USGS } \\
\text { site no. }\end{array}$ & Date & Time & $\begin{array}{c}\text { Water level } \\
\text { (ft blsd) }\end{array}$ & $\begin{array}{c}\text { Water-level } \\
\text { status }\end{array}$ & $\begin{array}{c}\text { Measurement } \\
\text { method }\end{array}$ \\
\hline \multirow[t]{25}{*}{$46 X 115$} & 391110078015801 & 10/21/2002 & 1213 & 35.92 & & Steel tape \\
\hline & & 01/23/2003 & 1133 & 9.58 & & Steel tape \\
\hline & & 04/16/2003 & 1300 & 3.66 & & Steel tape \\
\hline & & 07/23/2003 & 1250 & 17.82 & & Steel tape \\
\hline & & 10/22/2003 & 1020 & 12.03 & & Steel tape \\
\hline & & 02/05/2004 & 1410 & 12.10 & & Steel tape \\
\hline & & 04/08/2004 & 0945 & 8.59 & & Steel tape \\
\hline & & 07/22/2004 & 1415 & 12.12 & & Steel tape \\
\hline & & $10 / 20 / 2004$ & 1527 & 11.92 & & Steel tape \\
\hline & & 01/21/2005 & 0952 & 9.84 & & Steel tape \\
\hline & & 05/04/2005 & 1150 & 11.72 & & Steel tape \\
\hline & & 07/21/2005 & 1050 & 15.51 & & Steel tape \\
\hline & & $10 / 25 / 2005$ & 1002 & 24.32 & & Steel tape \\
\hline & & 01/26/2006 & 1411 & 9.39 & & Steel tape \\
\hline & & 05/02/2006 & 1223 & 16.85 & & Steel tape \\
\hline & & 07/20/2006 & 1338 & 14.28 & & Steel tape \\
\hline & & $10 / 20 / 2006$ & 0957 & 15.75 & & Steel tape \\
\hline & & 01/25/2007 & 1028 & 13.17 & & Steel tape \\
\hline & & 04/24/2007 & 1056 & 9.10 & & Steel tape \\
\hline & & 07/19/2007 & 1423 & 17.37 & & Steel tape \\
\hline & & $10 / 19 / 2007$ & 0910 & 31.24 & & Steel tape \\
\hline & & 01/24/2008 & 1438 & 34.03 & & Steel tape \\
\hline & & 04/17/2008 & 1143 & 14.75 & & Steel tape \\
\hline & & 07/16/2008 & 1303 & 14.01 & & Steel tape \\
\hline & & $10 / 22 / 2008$ & 1328 & 22.08 & & Steel tape \\
\hline \multirow[t]{4}{*}{$46 X 116$} & 391031078022301 & 10/21/2002 & 1055 & 54.99 & & Steel tape \\
\hline & & 01/23/2003 & 1102 & 31.74 & & Steel tape \\
\hline & & 04/16/2003 & 1235 & 27.90 & & Steel tape \\
\hline & & 07/24/2003 & 1430 & 32.57 & & Steel tape \\
\hline \multirow[t]{25}{*}{$46 X 117$} & 391044078015801 & $10 / 21 / 2002$ & 1145 & 48.10 & & Steel tape \\
\hline & & 01/23/2003 & 1117 & 24.39 & & Steel tape \\
\hline & & 04/16/2003 & 1250 & 21.27 & & Steel tape \\
\hline & & 07/23/2003 & 1235 & 24.40 & & Steel tape \\
\hline & & $10 / 22 / 2003$ & 1010 & 25.46 & & Steel tape \\
\hline & & 02/05/2004 & 1430 & 25.24 & & Steel tape \\
\hline & & 04/08/2004 & 0932 & 23.21 & & Steel tape \\
\hline & & 07/22/2004 & 1422 & 25.81 & & Steel tape \\
\hline & & $10 / 20 / 2004$ & 1512 & 25.98 & & Steel tape \\
\hline & & 01/21/2005 & 1005 & 24.83 & & Steel tape \\
\hline & & 05/04/2005 & 1134 & 25.22 & & Steel tape \\
\hline & & 07/21/2005 & 1059 & 27.44 & & Steel tape \\
\hline & & $10 / 25 / 2005$ & 1013 & 37.05 & & Steel tape \\
\hline & & 01/26/2006 & 1420 & 25.50 & & Steel tape \\
\hline & & 05/02/2006 & 1230 & 28.20 & & Steel tape \\
\hline & & 07/20/2006 & 1345 & 27.09 & & Steel tape \\
\hline & & $10 / 20 / 2006$ & 0945 & 27.84 & & Steel tape \\
\hline & & $01 / 25 / 2007$ & 1038 & 26.49 & & Steel tape \\
\hline & & $04 / 24 / 2007$ & 1036 & 23.90 & & Steel tape \\
\hline & & 07/19/2007 & 1408 & 28.10 & & Steel tape \\
\hline & & 10/19/2007 & 0858 & 45.34 & & Steel tape \\
\hline & & 01/24/2008 & 1414 & 47.53 & & Steel tape \\
\hline & & 04/17/2008 & 1131 & 27.63 & & Steel tape \\
\hline & & 07/16/2008 & 1252 & 26.45 & & Steel tape \\
\hline & & $10 / 22 / 2008$ & 1312 & 33.56 & & Steel tape \\
\hline
\end{tabular}


Appendix 3. Water-level measurements from wells in Clarke County, Virginia, 2002-2008._Continued

[ft blsd, feet below land surface datum. See figure 15 for location of wells]

\begin{tabular}{|c|c|c|c|c|c|c|}
\hline $\begin{array}{c}\text { USGS } \\
\text { local no. }\end{array}$ & $\begin{array}{c}\text { USGS } \\
\text { site no. }\end{array}$ & Date & Time & $\begin{array}{c}\text { Water level } \\
\text { (ft blsd) }\end{array}$ & $\begin{array}{c}\text { Water-level } \\
\text { status }\end{array}$ & $\begin{array}{c}\text { Measurement } \\
\text { method }\end{array}$ \\
\hline \multirow[t]{25}{*}{$46 X 118$} & 391044078005601 & $10 / 21 / 2002$ & 1305 & 47.51 & & Steel tape \\
\hline & & 01/23/2003 & 1325 & 27.31 & & Steel tape \\
\hline & & $04 / 15 / 2003$ & 1245 & 17.84 & & Steel tape \\
\hline & & $07 / 23 / 2003$ & 0915 & 21.75 & & Steel tape \\
\hline & & $10 / 22 / 2003$ & 1055 & 28.37 & & Steel tape \\
\hline & & 02/04/2004 & 1445 & 24.73 & & Steel tape \\
\hline & & 04/07/2004 & 1250 & 22.03 & & Steel tape \\
\hline & & 07/28/2004 & 1354 & 27.74 & & Steel tape \\
\hline & & $10 / 20 / 2004$ & 1459 & 30.97 & & Steel tape \\
\hline & & 01/20/2005 & 1259 & 28.47 & & Steel tape \\
\hline & & 05/06/2005 & 0929 & 24.79 & & Steel tape \\
\hline & & 07/22/2005 & 0950 & 33.58 & & Steel tape \\
\hline & & $10 / 25 / 2005$ & 1133 & 43.33 & & Steel tape \\
\hline & & 01/26/2006 & 1316 & 33.37 & & Steel tape \\
\hline & & 05/01/2006 & 1526 & 38.08 & & Steel tape \\
\hline & & 07/19/2006 & 1547 & 33.73 & & Steel tape \\
\hline & & $10 / 18 / 2006$ & 1529 & 40.11 & & Steel tape \\
\hline & & 01/25/2007 & 1146 & 32.91 & & Steel tape \\
\hline & & $04 / 24 / 2007$ & 1605 & 24.64 & & Steel tape \\
\hline & & 07/18/2007 & 1523 & 36.92 & & Steel tape \\
\hline & & $10 / 18 / 2007$ & 1532 & 46.07 & & Steel tape \\
\hline & & 01/24/2008 & 1543 & 46.74 & & Steel tape \\
\hline & & 04/17/2008 & 1359 & 37.92 & & Steel tape \\
\hline & & 07/17/2008 & 0954 & 29.96 & & Steel tape \\
\hline & & $10 / 22 / 2008$ & 1402 & 42.75 & & Steel tape \\
\hline $46 X 119$ & 391044078010801 & $10 / 22 / 2002$ & 1035 & 54.10 & & Steel tape \\
\hline $46 X 120$ & 391044078010901 & $10 / 22 / 2002$ & 1025 & 65.70 & & Steel tape \\
\hline \multirow[t]{24}{*}{$46 X 121$} & 390824078050101 & $10 / 23 / 2002$ & 0940 & 36.12 & & Steel tape \\
\hline & & $01 / 28 / 2003$ & 1335 & 28.38 & & Steel tape \\
\hline & & 04/18/2003 & 0915 & 25.58 & & Steel tape \\
\hline & & 07/24/2003 & 0845 & 27.26 & & Steel tape \\
\hline & & $10 / 28 / 2003$ & 0815 & 28.31 & & Steel tape \\
\hline & & 04/07/2004 & 0900 & 24.95 & & Steel tape \\
\hline & & 07/28/2004 & 0919 & 32.12 & & Steel tape \\
\hline & & $10 / 22 / 2004$ & 0914 & 29.85 & & Steel tape \\
\hline & & 01/27/2005 & 0914 & 27.27 & & Steel tape \\
\hline & & 05/06/2005 & 0857 & 28.74 & & Steel tape \\
\hline & & 07/22/2005 & 0909 & 31.30 & & Steel tape \\
\hline & & $10 / 26 / 2005$ & 0950 & 33.76 & & Steel tape \\
\hline & & 01/25/2006 & 1106 & 26.18 & & Steel tape \\
\hline & & 05/02/2006 & 0846 & 31.34 & & Steel tape \\
\hline & & 07/20/2006 & 0811 & 29.81 & & Steel tape \\
\hline & & $10 / 25 / 2006$ & 0921 & 28.54 & & Steel tape \\
\hline & & 01/30/2007 & 1036 & 27.79 & & Steel tape \\
\hline & & 04/24/2007 & 0942 & 26.63 & & Steel tape \\
\hline & & 07/19/2007 & 0936 & 31.95 & & Steel tape \\
\hline & & $10 / 18 / 2007$ & 0916 & 34.98 & & Steel tape \\
\hline & & 01/24/2008 & 0950 & 33.43 & & Steel tape \\
\hline & & 04/17/2008 & 0908 & 29.20 & & Steel tape \\
\hline & & 07/16/2008 & 0854 & 30.85 & & Steel tape \\
\hline & & $10 / 22 / 2008$ & 1007 & 34.13 & & Steel tape \\
\hline \multirow[t]{5}{*}{$46 X 122$} & 390904078003101 & $10 / 22 / 2003$ & 0935 & 20.59 & & Steel tape \\
\hline & & 04/07/2004 & 1020 & 16.01 & & Steel tape \\
\hline & & 07/27/2004 & 1356 & 21.89 & & Steel tape \\
\hline & & $10 / 21 / 2004$ & 1046 & 25.42 & & Steel tape \\
\hline & & 01/20/2005 & 1209 & 23.48 & & Steel tape \\
\hline
\end{tabular}


Appendix 3. Water-level measurements from wells in Clarke County, Virginia, 2002-2008.-Continued

[ft blsd, feet below land surface datum. See figure 15 for location of wells]

\begin{tabular}{|c|c|c|c|c|c|c|}
\hline $\begin{array}{l}\text { USGS } \\
\text { local no. }\end{array}$ & $\begin{array}{l}\text { USGS } \\
\text { site no. }\end{array}$ & Date & Time & $\begin{array}{l}\text { Water level } \\
\text { (ft blsd) }\end{array}$ & $\begin{array}{c}\text { Water-level } \\
\text { status }\end{array}$ & $\begin{array}{c}\text { Measurement } \\
\text { method }\end{array}$ \\
\hline \multirow{15}{*}{\multicolumn{2}{|c|}{ 46X122 (cont.) }} & 05/06/2005 & 1056 & 20.05 & & Steel tape \\
\hline & & 07/21/2005 & 1310 & 27.15 & & Steel tape \\
\hline & & $10 / 26 / 2005$ & 1152 & 33.04 & & Steel tape \\
\hline & & 01/25/2006 & 1208 & 27.81 & & Steel tape \\
\hline & & 05/02/2006 & 1049 & 32.54 & & Steel tape \\
\hline & & 07/20/2006 & 0918 & 28.82 & & Steel tape \\
\hline & & $10 / 20 / 2006$ & 1142 & 32.57 & & Steel tape \\
\hline & & 01/24/2007 & 1227 & 28.19 & & Steel tape \\
\hline & & 04/18/2007 & 1021 & 21.70 & & Steel tape \\
\hline & & 07/19/2007 & 1518 & 30.75 & & Steel tape \\
\hline & & $10 / 19 / 2007$ & 1104 & 38.79 & & Steel tape \\
\hline & & 01/24/2008 & 1127 & 38.15 & & Steel tape \\
\hline & & 04/17/2008 & 1056 & 32.39 & & Steel tape \\
\hline & & 07/16/2008 & 1108 & 24.71 & & Steel tape \\
\hline & & $10 / 23 / 2008$ & 1233 & 34.25 & & Steel tape \\
\hline \multirow[t]{25}{*}{$46 X 123$} & 390905078003301 & 10/21/2002 & 1335 & 38.03 & & Steel tape \\
\hline & & 01/23/2003 & 1015 & 23.45 & & Steel tape \\
\hline & & 04/16/2003 & 1130 & 9.01 & & Steel tape \\
\hline & & 07/21/2003 & 1420 & 12.70 & & Steel tape \\
\hline & & $10 / 22 / 2003$ & 0925 & 20.47 & & Steel tape \\
\hline & & 01/22/2004 & 1025 & 15.88 & & Steel tape \\
\hline & & 04/07/2004 & 1008 & 15.99 & & Steel tape \\
\hline & & 07/27/2004 & 1345 & 21.69 & & Steel tape \\
\hline & & $10 / 21 / 2004$ & 1042 & 25.42 & & Steel tape \\
\hline & & 01/20/2005 & 1205 & 23.61 & & Steel tape \\
\hline & & 05/06/2005 & 1048 & 19.88 & & Steel tape \\
\hline & & 07/21/2005 & 1318 & 27.23 & & Steel tape \\
\hline & & $10 / 26 / 2005$ & 1131 & 33.40 & & Steel tape \\
\hline & & 01/25/2006 & 1201 & 27.98 & & Steel tape \\
\hline & & 05/02/2006 & 1041 & 32.15 & & Steel tape \\
\hline & & 07/20/2006 & 0846 & 28.94 & & Steel tape \\
\hline & & $10 / 20 / 2006$ & 1140 & 32.73 & & Steel tape \\
\hline & & 01/24/2007 & 1224 & 28.19 & & Steel tape \\
\hline & & 04/18/2007 & 1012 & 21.35 & & Steel tape \\
\hline & & 07/19/2007 & 1516 & 30.72 & & Steel tape \\
\hline & & 10/19/2007 & 1102 & 36.65 & & Steel tape \\
\hline & & 01/24/2008 & 1125 & 37.84 & & Steel tape \\
\hline & & 04/17/2008 & 1054 & 32.57 & & Steel tape \\
\hline & & 07/16/2008 & 1106 & 24.45 & & Steel tape \\
\hline & & $10 / 23 / 2008$ & 1232 & 33.97 & & Steel tape \\
\hline \multirow[t]{16}{*}{$46 X 124$} & 390941078001201 & $10 / 15 / 2002$ & 1240 & 50.70 & & Steel tape \\
\hline & & 01/24/2003 & 0850 & 32.81 & & Steel tape \\
\hline & & 04/16/2003 & 1115 & 16.58 & & Steel tape \\
\hline & & 07/21/2003 & 1445 & 20.08 & & Steel tape \\
\hline & & $10 / 21 / 2003$ & 0845 & 28.75 & & Steel tape \\
\hline & & 01/21/2004 & 1530 & 23.85 & & Steel tape \\
\hline & & 04/05/2004 & 1615 & 24.73 & & Steel tape \\
\hline & & 07/20/2004 & 1142 & 28.50 & & Steel tape \\
\hline & & $10 / 19 / 2004$ & 1027 & 34.56 & & Steel tape \\
\hline & & 01/18/2005 & 1559 & 33.55 & & Steel tape \\
\hline & & 04/27/2005 & 1439 & 27.17 & & Steel tape \\
\hline & & 07/19/2005 & 1352 & 35.76 & & Steel tape \\
\hline & & 10/19/2005 & 1531 & 44.40 & & Steel tape \\
\hline & & 01/24/2006 & 1553 & 37.99 & & Steel tape \\
\hline & & 04/28/2006 & 0741 & 41.82 & & Steel tape \\
\hline & & 07/19/2006 & 1535 & 39.45 & & Steel tape \\
\hline
\end{tabular}


88 Hydrogeology and Groundwater Availability in Clarke County, Virginia

Appendix 3. Water-level measurements from wells in Clarke County, Virginia, 2002-2008.-Continued

[ft blsd, feet below land surface datum. See figure 15 for location of wells]

\begin{tabular}{|c|c|c|c|c|c|c|}
\hline $\begin{array}{l}\text { USGS } \\
\text { local no. }\end{array}$ & $\begin{array}{l}\text { USGS } \\
\text { site no. }\end{array}$ & Date & Time & $\begin{array}{c}\text { Water level } \\
\text { (ft blsd) }\end{array}$ & $\begin{array}{c}\text { Water-level } \\
\text { status }\end{array}$ & $\begin{array}{l}\text { Measurement } \\
\text { method }\end{array}$ \\
\hline \multirow{9}{*}{\multicolumn{2}{|c|}{ 46X124 (cont.) }} & $10 / 19 / 2006$ & 1610 & 42.81 & & Steel tape \\
\hline & & 01/23/2007 & 1634 & 38.45 & & Steel tape \\
\hline & & $04 / 18 / 2007$ & 0947 & 31.41 & & Steel tape \\
\hline & & 07/17/2007 & 1318 & 40.83 & & Steel tape \\
\hline & & $10 / 17 / 2007$ & 1658 & 48.73 & & Steel tape \\
\hline & & 01/23/2008 & 1604 & 49.91 & & Steel tape \\
\hline & & 04/16/2008 & 0951 & 42.48 & & Steel tape \\
\hline & & $07 / 14 / 2008$ & 1342 & 37.01 & & Steel tape \\
\hline & & $10 / 20 / 2008$ & 1607 & 49.15 & & Steel tape \\
\hline \multirow[t]{27}{*}{$46 X 125$} & 390948078001601 & $10 / 15 / 2002$ & 1315 & 45.43 & & Steel tape \\
\hline & & 01/29/2003 & 1600 & 27.03 & & Steel tape \\
\hline & & $04 / 17 / 2003$ & 0816 & 10.23 & & Steel tape \\
\hline & & 07/23/2003 & 0825 & 14.14 & & Steel tape \\
\hline & & $10 / 21 / 2003$ & 0835 & 22.73 & & Steel tape \\
\hline & & $01 / 22 / 2004$ & 0935 & 17.42 & & Steel tape \\
\hline & & $04 / 06 / 2004$ & 1706 & 18.44 & & Steel tape \\
\hline & & 07/21/2004 & 0915 & 22.75 & & Steel tape \\
\hline & & $10 / 19 / 2004$ & 1005 & 28.40 & & Steel tape \\
\hline & & 01/19/2005 & 1425 & 27.28 & & Steel tape \\
\hline & & $04 / 27 / 2005$ & 1410 & 20.58 & & Steel tape \\
\hline & & 07/19/2005 & 1332 & 30.19 & & Steel tape \\
\hline & & $10 / 19 / 2005$ & 1523 & 38.53 & & Steel tape \\
\hline & & 01/24/2006 & 1546 & 32.03 & & Steel tape \\
\hline & & 05/03/2006 & 0813 & 36.67 & & Steel tape \\
\hline & & 07/19/2006 & 1528 & 33.30 & & Steel tape \\
\hline & & $10 / 19 / 2006$ & 1554 & 37.06 & & Steel tape \\
\hline & & 01/23/2007 & 1551 & 31.97 & & Steel tape \\
\hline & & 04/17/2007 & 1533 & 24.22 & & Steel tape \\
\hline & & 07/17/2007 & 1309 & 34.46 & & Steel tape \\
\hline & & $10 / 17 / 2007$ & 1650 & 42.16 & & Steel tape \\
\hline & & 01/23/2008 & 1552 & 43.56 & & Steel tape \\
\hline & & 04/15/2008 & 1522 & 36.73 & & Steel tape \\
\hline & & 04/18/2008 & 0912 & 36.86 & & Steel tape \\
\hline & & 07/16/2008 & 1119 & 26.63 & & Steel tape \\
\hline & & 07/22/2008 & 1110 & 27.55 & & Steel tape \\
\hline & & $10 / 21 / 2008$ & 1536 & 38.40 & & Steel tape \\
\hline \multirow[t]{9}{*}{$46 \times 126$} & 390953078001901 & $10 / 15 / 2002$ & 1335 & 44.26 & & Steel tape \\
\hline & & $01 / 29 / 2003$ & 1545 & 25.39 & & Steel tape \\
\hline & & 04/17/2003 & 0825 & 8.64 & & Steel tape \\
\hline & & 07/23/2003 & 0810 & 12.60 & & Steel tape \\
\hline & & $10 / 21 / 2003$ & 0815 & 21.25 & & Steel tape \\
\hline & & $01 / 22 / 2004$ & 1000 & 15.87 & & Steel tape \\
\hline & & $04 / 06 / 2004$ & 1705 & 17.05 & & Steel tape \\
\hline & & 07/21/2004 & 0957 & 21.26 & & Steel tape \\
\hline & & 01/19/2005 & 1440 & 25.94 & & Steel tape \\
\hline \multirow[t]{4}{*}{$46 X 127$} & 391350078022001 & $10 / 21 / 2002$ & 1800 & 58.81 & & Steel tape \\
\hline & & $01 / 30 / 2003$ & 1445 & 31.31 & & Steel tape \\
\hline & & 04/17/2003 & 1330 & 26.63 & & Steel tape \\
\hline & & 07/24/2003 & 1155 & 31.91 & & Steel tape \\
\hline \multirow[t]{4}{*}{$46 X 128$} & 391148078000201 & $10 / 24 / 2002$ & 1240 & 53.63 & & Steel tape \\
\hline & & $01 / 30 / 2003$ & 1230 & 30.79 & & Steel tape \\
\hline & & $04 / 15 / 2003$ & 1500 & 15.56 & & Steel tape \\
\hline & & $07 / 23 / 2003$ & 1400 & 23.51 & & Steel tape \\
\hline
\end{tabular}


Appendix 3. Water-level measurements from wells in Clarke County, Virginia, 2002-2008.-Continued

[ft blsd, feet below land surface datum. See figure 15 for location of wells]

\begin{tabular}{|c|c|c|c|c|c|c|}
\hline $\begin{array}{c}\text { USGS } \\
\text { local no. }\end{array}$ & $\begin{array}{l}\text { USGS } \\
\text { site no. }\end{array}$ & Date & Time & $\begin{array}{c}\text { Water level } \\
\text { (ft blsd) }\end{array}$ & $\begin{array}{c}\text { Water-level } \\
\text { status }\end{array}$ & $\begin{array}{c}\text { Measurement } \\
\text { method }\end{array}$ \\
\hline \multirow{22}{*}{\multicolumn{2}{|c|}{ 46X128 (cont.) }} & $10 / 23 / 2003$ & 1000 & 30.93 & & Steel tape \\
\hline & & 02/04/2004 & 1530 & 27.45 & & Steel tape \\
\hline & & 04/14/2004 & 1030 & 17.92 & & Steel tape \\
\hline & & 07/28/2004 & 1456 & 28.17 & & Steel tape \\
\hline & & $10 / 20 / 2004$ & 1436 & 34.22 & & Steel tape \\
\hline & & 01/20/2005 & 1351 & 30.73 & & Steel tape \\
\hline & & 05/04/2005 & 1252 & 26.22 & & Steel tape \\
\hline & & 07/22/2005 & 1101 & 38.52 & & Steel tape \\
\hline & & $10 / 24 / 2005$ & 1643 & 52.14 & & Steel tape \\
\hline & & 01/25/2006 & 1526 & 36.86 & & Steel tape \\
\hline & & 05/01/2006 & 1602 & 41.90 & & Steel tape \\
\hline & & 07/19/2006 & 1606 & 40.09 & & Steel tape \\
\hline & & $10 / 18 / 2006$ & 1546 & 48.87 & & Steel tape \\
\hline & & 01/25/2007 & 1125 & 37.31 & & Steel tape \\
\hline & & 04/24/2007 & 1726 & 26.34 & & Steel tape \\
\hline & & 07/18/2007 & 1502 & 41.29 & & Steel tape \\
\hline & & $10 / 17 / 2007$ & 1438 & 56.29 & & Steel tape \\
\hline & & 01/24/2008 & 1524 & 55.09 & & Steel tape \\
\hline & & 04/21/2008 & 1136 & 33.65 & & Steel tape \\
\hline & & 07/17/2008 & 1324 & 32.85 & & Steel tape \\
\hline & & 07/31/2008 & 1416 & 35.53 & & Steel tape \\
\hline & & $10 / 22 / 2008$ & 1429 & 49.99 & & Steel tape \\
\hline \multirow[t]{6}{*}{$46 X 129$} & 391234078000501 & $10 / 17 / 2002$ & 1340 & 41.55 & & Steel tape \\
\hline & & 01/30/2003 & 1345 & 17.83 & & Steel tape \\
\hline & & 04/15/2003 & 1335 & 5.19 & & Steel tape \\
\hline & & 07/23/2003 & 1045 & 10.94 & & Steel tape \\
\hline & & $10 / 29 / 2003$ & 0745 & 17.41 & & Steel tape \\
\hline & & 01/22/2004 & 1520 & 11.76 & & Steel tape \\
\hline $46 X 130$ & 391422078013201 & $10 / 17 / 2002$ & 1150 & 83.01 & & Steel tape \\
\hline \multirow[t]{30}{*}{$46 X 132$} & 391416078013401 & $10 / 17 / 2002$ & 1030 & 96.42 & & Steel tape \\
\hline & & 01/23/2003 & 1445 & 59.03 & & Steel tape \\
\hline & & 04/17/2003 & 1440 & 48.28 & & Steel tape \\
\hline & & $07 / 24 / 2003$ & 1100 & 55.04 & & Steel tape \\
\hline & & $10 / 22 / 2003$ & 1340 & 60.39 & & Steel tape \\
\hline & & 02/04/2004 & 1630 & 59.54 & & Steel tape \\
\hline & & 04/07/2004 & 1527 & 55.87 & & Steel tape \\
\hline & & 07/28/2004 & 1205 & 57.09 & & Steel tape \\
\hline & & $10 / 20 / 2004$ & 1615 & 61.45 & & Steel tape \\
\hline & & 01/20/2005 & 1513 & 56.82 & & Steel tape \\
\hline & & 01/28/2005 & 0957 & 58.05 & & Steel tape \\
\hline & & 05/03/2005 & 1633 & 57.88 & & Steel tape \\
\hline & & 07/20/2005 & 1600 & 70.01 & & Steel tape \\
\hline & & $10 / 26 / 2005$ & 1518 & 84.25 & & Steel tape \\
\hline & & 01/27/2006 & 0927 & 71.89 & & Steel tape \\
\hline & & 05/04/2006 & 1405 & 75.63 & & Steel tape \\
\hline & & 07/20/2006 & 1318 & 78.68 & & Steel tape \\
\hline & & $11 / 03 / 2006$ & 0945 & 78.16 & & Steel tape \\
\hline & & 01/24/2007 & 1540 & 64.95 & & Steel tape \\
\hline & & 04/25/2007 & 1458 & 59.22 & & Steel tape \\
\hline & & 07/18/2007 & 1613 & 72.68 & & Steel tape \\
\hline & & $10 / 19 / 2007$ & 0947 & 88.47 & & Steel tape \\
\hline & & 11/09/2007 & 1144 & 90.74 & & Steel tape \\
\hline & & 01/22/2008 & 1613 & 90.01 & & Steel tape \\
\hline & & 02/21/2008 & 1329 & 86.96 & & Steel tape \\
\hline & & 04/17/2008 & 1658 & 74.76 & & Steel tape \\
\hline & & 05/08/2008 & 1512 & 62.71 & & Steel tape \\
\hline & & 07/17/2008 & 1247 & 64.60 & & Steel tape \\
\hline & & 07/31/2008 & 1710 & 66.11 & & Steel tape \\
\hline & & $10 / 22 / 2008$ & 1541 & 80.65 & & Steel tape \\
\hline
\end{tabular}




\section{Hydrogeology and Groundwater Availability in Clarke County, Virginia}

Appendix 3. Water-level measurements from wells in Clarke County, Virginia, 2002-2008._Continued

[ft blsd, feet below land surface datum. See figure 15 for location of wells]

\begin{tabular}{|c|c|c|c|c|c|c|}
\hline $\begin{array}{c}\text { USGS } \\
\text { local no. }\end{array}$ & $\begin{array}{l}\text { USGS } \\
\text { site no. }\end{array}$ & Date & Time & $\begin{array}{c}\text { Water level } \\
\text { (ft blsd) }\end{array}$ & $\begin{array}{l}\text { Water-level } \\
\text { status }\end{array}$ & $\begin{array}{c}\text { Measurement } \\
\text { method }\end{array}$ \\
\hline \multirow[t]{25}{*}{$46 X 133$} & \multirow[t]{25}{*}{391146078005201} & $10 / 17 / 2002$ & 1407 & 44.14 & & Steel tape \\
\hline & & 01/23/2003 & 1149 & 20.93 & & Steel tape \\
\hline & & $04 / 15 / 2003$ & 1600 & 10.27 & & Steel tape \\
\hline & & 07/23/2003 & 1310 & 15.96 & & Steel tape \\
\hline & & $10 / 22 / 2003$ & 1040 & 22.73 & & Steel tape \\
\hline & & $02 / 04 / 2004$ & 1510 & 20.37 & & Steel tape \\
\hline & & 04/07/2004 & 1325 & 12.90 & & Steel tape \\
\hline & & 07/28/2004 & 1017 & 19.96 & & Steel tape \\
\hline & & $10 / 20 / 2004$ & 1413 & 24.51 & & Steel tape \\
\hline & & 01/20/2005 & 1319 & 21.95 & & Steel tape \\
\hline & & 05/04/2005 & 1212 & 19.46 & & Steel tape \\
\hline & & $07 / 22 / 2005$ & 1018 & 30.95 & & Steel tape \\
\hline & & $10 / 24 / 2005$ & 1538 & 45.00 & & Steel tape \\
\hline & & 01/26/2006 & 1356 & 30.28 & & Steel tape \\
\hline & & 05/01/2006 & 1545 & 36.08 & & Steel tape \\
\hline & & 07/20/2006 & 1156 & 34.02 & & Steel tape \\
\hline & & $10 / 20 / 2006$ & 1015 & 39.60 & & Steel tape \\
\hline & & 01/25/2007 & 1057 & 30.43 & & Steel tape \\
\hline & & $04 / 24 / 2007$ & 1120 & 19.10 & & Steel tape \\
\hline & & $07 / 18 / 2007$ & 1438 & 34.46 & & Steel tape \\
\hline & & 10/18/2007 & 1554 & 48.76 & & Steel tape \\
\hline & & 01/24/2008 & 1459 & 48.98 & & Steel tape \\
\hline & & $04 / 17 / 2008$ & 1430 & 34.07 & & Steel tape \\
\hline & & 07/16/2008 & 1319 & 24.65 & & Steel tape \\
\hline & & 10/22/2008 & 1346 & 40.50 & & Steel tape \\
\hline \multirow[t]{25}{*}{$46 X 134$} & \multirow[t]{25}{*}{390923078023801} & $10 / 22 / 2002$ & 0805 & 71.42 & & Steel tape \\
\hline & & 01/23/2003 & 1040 & 39.56 & & Steel tape \\
\hline & & 04/16/2003 & 1210 & 32.13 & & Steel tape \\
\hline & & 07/24/2003 & 0940 & 40.52 & & Steel tape \\
\hline & & $10 / 22 / 2003$ & 0845 & 46.79 & & Steel tape \\
\hline & & 01/22/2004 & 1105 & 41.97 & & Steel tape \\
\hline & & 04/07/2004 & 0945 & 41.14 & & Steel tape \\
\hline & & 07/20/2004 & 0943 & 51.94 & & Steel tape \\
\hline & & $10 / 19 / 2004$ & 0942 & 52.63 & & Steel tape \\
\hline & & 01/20/2005 & 1235 & 44.98 & & Steel tape \\
\hline & & 05/04/2005 & 0956 & 42.98 & & Steel tape \\
\hline & & $07 / 21 / 2005$ & 1348 & 60.67 & & Steel tape \\
\hline & & 10/26/2005 & 1105 & 67.54 & & Steel tape \\
\hline & & 01/25/2006 & 1142 & 50.19 & & Steel tape \\
\hline & & 05/02/2006 & 1106 & 60.62 & & Steel tape \\
\hline & & 07/20/2006 & 0844 & 55.98 & & Steel tape \\
\hline & & $10 / 20 / 2006$ & 1108 & 58.09 & & Steel tape \\
\hline & & $01 / 24 / 2007$ & 1155 & 48.25 & & Steel tape \\
\hline & & 04/18/2007 & 1051 & 39.23 & & Steel tape \\
\hline & & 07/19/2007 & 1352 & 62.75 & & Steel tape \\
\hline & & $10 / 18 / 2007$ & 1513 & 74.70 & & Steel tape \\
\hline & & 01/24/2008 & 1041 & 73.52 & & Steel tape \\
\hline & & 04/17/2008 & 1015 & 59.45 & & Steel tape \\
\hline & & 07/16/2008 & 1032 & 54.07 & & Steel tape \\
\hline & & $10 / 21 / 2008$ & 1152 & 70.49 & & Steel tape \\
\hline \multirow[t]{9}{*}{$46 \times 135$} & \multirow[t]{9}{*}{391456078014501} & $01 / 27 / 2005$ & 1220 & 74.78 & & Steel tape \\
\hline & & 05/06/2005 & 0856 & 76.70 & & Steel tape \\
\hline & & 07/26/2005 & 1606 & 102.44 & & Steel tape \\
\hline & & $10 / 28 / 2005$ & 0936 & 100.87 & & Steel tape \\
\hline & & 01/27/2006 & 0906 & 71.78 & & Steel tape \\
\hline & & 05/04/2006 & 1338 & 102.48 & & Steel tape \\
\hline & & 07/20/2006 & 1300 & 89.77 & & Steel tape \\
\hline & & 01/31/2007 & 1002 & 84.69 & & Steel tape \\
\hline & & $04 / 25 / 2007$ & 1514 & 68.53 & & Steel tape \\
\hline
\end{tabular}


Appendix 3. Water-level measurements from wells in Clarke County, Virginia, 2002-2008.-Continued

[ft blsd, feet below land surface datum. See figure 15 for location of wells]

\begin{tabular}{|c|c|c|c|c|c|c|}
\hline $\begin{array}{c}\text { USGS } \\
\text { local no. }\end{array}$ & $\begin{array}{l}\text { USGS } \\
\text { site no. }\end{array}$ & Date & Time & $\begin{array}{l}\text { Water level } \\
\text { (ft blsd) }\end{array}$ & $\begin{array}{c}\text { Water-level } \\
\text { status }\end{array}$ & $\begin{array}{c}\text { Measurement } \\
\text { method }\end{array}$ \\
\hline \multirow[t]{25}{*}{$47 W 83$} & 390656077570801 & $10 / 24 / 2002$ & 1115 & 84.57 & & Steel tape \\
\hline & & $01 / 30 / 2003$ & 1015 & 77.20 & & Steel tape \\
\hline & & $04 / 17 / 2003$ & 1140 & 69.97 & & Steel tape \\
\hline & & 07/22/2003 & 1540 & 72.46 & & Steel tape \\
\hline & & $10 / 23 / 2003$ & 1155 & 75.97 & & Steel tape \\
\hline & & $02 / 05 / 2004$ & 1305 & 74.98 & & Steel tape \\
\hline & & 04/06/2004 & 1155 & 75.02 & & Steel tape \\
\hline & & 07/28/2004 & 1327 & 79.00 & & Steel tape \\
\hline & & $10 / 20 / 2004$ & 1109 & 77.41 & & Steel tape \\
\hline & & 01/21/2005 & 1040 & 74.83 & & Steel tape \\
\hline & & 05/03/2005 & 1300 & 74.30 & & Steel tape \\
\hline & & 07/19/2005 & 1310 & 78.90 & & Steel tape \\
\hline & & $10 / 24 / 2005$ & 1352 & 87.86 & & Steel tape \\
\hline & & 01/26/2006 & 1105 & 77.66 & & Electric tape \\
\hline & & 05/01/2006 & 1352 & 81.73 & & Steel tape \\
\hline & & 07/20/2006 & 1009 & 83.32 & & Electric tape \\
\hline & & $10 / 19 / 2006$ & 1353 & 83.42 & & Steel tape \\
\hline & & $01 / 24 / 2007$ & 1124 & 79.58 & & Steel tape \\
\hline & & $04 / 25 / 2007$ & 1330 & 77.00 & & Steel tape \\
\hline & & 07/18/2007 & 1016 & 81.23 & & Steel tape \\
\hline & & $10 / 17 / 2007$ & 1409 & 87.11 & & Steel tape \\
\hline & & $01 / 23 / 2008$ & 1453 & 84.35 & & Steel tape \\
\hline & & 04/16/2008 & 1410 & 82.79 & & Steel tape \\
\hline & & 07/15/2008 & 1509 & 78.76 & & Steel tape \\
\hline & & $10 / 22 / 2008$ & 1140 & 82.46 & & Steel tape \\
\hline \multirow[t]{7}{*}{ 47W 84} & 390503077552601 & $10 / 23 / 2002$ & 1736 & 94.49 & Recently pumped & Steel tape \\
\hline & & $01 / 22 / 2003$ & 1235 & 90.72 & Recently pumped & Steel tape \\
\hline & & $04 / 22 / 2003$ & 1605 & 88.84 & Recently pumped & Steel tape \\
\hline & & $07 / 22 / 2003$ & 1055 & 92.01 & Recently pumped & Steel tape \\
\hline & & $10 / 21 / 2003$ & 1405 & 95.62 & Recently pumped & Steel tape \\
\hline & & $01 / 21 / 2004$ & 1240 & 93.98 & Recently pumped & Steel tape \\
\hline & & $04 / 14 / 2004$ & 1242 & 93.04 & & Steel tape \\
\hline \multirow[t]{10}{*}{ 47W 85} & 390422077583501 & $10 / 23 / 2002$ & 1451 & 93.82 & & Steel tape \\
\hline & & $01 / 29 / 2003$ & 1405 & 85.57 & & Steel tape \\
\hline & & $04 / 24 / 2003$ & 1045 & 67.54 & & Steel tape \\
\hline & & 07/31/2003 & 1020 & 69.10 & & Steel tape \\
\hline & & $10 / 29 / 2003$ & 1045 & 76.24 & & Steel tape \\
\hline & & $04 / 13 / 2004$ & 1130 & 66.78 & & Steel tape \\
\hline & & 07/29/2004 & 1100 & 77.50 & & Steel tape \\
\hline & & $10 / 25 / 2004$ & 1213 & 84.40 & & Steel tape \\
\hline & & 05/04/2005 & 1143 & 73.17 & & Steel tape \\
\hline & & 07/21/2005 & 1125 & 79.23 & & Steel tape \\
\hline \multirow[t]{15}{*}{ 47W 86} & 390253077542301 & $10 / 23 / 2002$ & 1536 & 35.34 & & Steel tape \\
\hline & & $01 / 22 / 2003$ & 1015 & 29.88 & & Steel tape \\
\hline & & $04 / 22 / 2003$ & 1320 & 27.97 & & Steel tape \\
\hline & & 07/22/2003 & 0915 & 30.86 & & Steel tape \\
\hline & & $10 / 29 / 2003$ & 1230 & 32.59 & & Steel tape \\
\hline & & $01 / 21 / 2004$ & 1145 & 31.17 & & Steel tape \\
\hline & & 04/08/2004 & 1310 & 26.20 & & Steel tape \\
\hline & & 07/29/2004 & 1323 & 36.14 & & Steel tape \\
\hline & & $10 / 29 / 2004$ & 0955 & 34.88 & & Steel tape \\
\hline & & 01/19/2005 & 1114 & 24.15 & & Steel tape \\
\hline & & 04/27/2005 & 1116 & 28.49 & & Steel tape \\
\hline & & 07/19/2005 & 1121 & 30.58 & & Steel tape \\
\hline & & 10/19/2005 & 1135 & 34.50 & & Steel tape \\
\hline & & $01 / 24 / 2006$ & 1045 & 28.48 & & Steel tape \\
\hline & & 05/03/2006 & 1439 & 28.96 & & Steel tape \\
\hline
\end{tabular}




\section{Hydrogeology and Groundwater Availability in Clarke County, Virginia}

Appendix 3. Water-level measurements from wells in Clarke County, Virginia, 2002-2008.—Continued

[ft blsd, feet below land surface datum. See figure 15 for location of wells]

\begin{tabular}{|c|c|c|c|c|c|c|}
\hline $\begin{array}{c}\text { USGS } \\
\text { local no. }\end{array}$ & $\begin{array}{c}\text { USGS } \\
\text { site no. }\end{array}$ & Date & Time & $\begin{array}{c}\text { Water level } \\
\text { (ft blsd) }\end{array}$ & $\begin{array}{c}\text { Water-level } \\
\text { status }\end{array}$ & $\begin{array}{c}\text { Measurement } \\
\text { method }\end{array}$ \\
\hline \multirow{10}{*}{\multicolumn{2}{|c|}{ 47W 86 (cont.) }} & 07/19/2006 & 1339 & 30.99 & & Steel tape \\
\hline & & 10/19/2006 & 1144 & 33.77 & & Steel tape \\
\hline & & 01/23/2007 & 1139 & 30.39 & & Steel tape \\
\hline & & 04/17/2007 & 1240 & 28.66 & & Steel tape \\
\hline & & 07/17/2007 & 1057 & 38.39 & & Steel tape \\
\hline & & $10 / 17 / 2007$ & 1115 & 41.14 & & Steel tape \\
\hline & & 01/23/2008 & 1232 & 38.23 & & Steel tape \\
\hline & & 04/15/2008 & 1217 & 32.10 & & Steel tape \\
\hline & & 07/15/2008 & 1122 & 34.56 & & Steel tape \\
\hline & & $10 / 21 / 2008$ & 1301 & 36.90 & & Steel tape \\
\hline \multirow[t]{6}{*}{$47 \mathrm{~W} 87$} & 390220077560601 & 01/31/2003 & 1145 & 61.55 & & Steel tape \\
\hline & & 04/22/2003 & 1300 & 58.73 & & Steel tape \\
\hline & & 07/31/2003 & 1253 & 61.80 & & Steel tape \\
\hline & & 10/29/2003 & 1630 & 59.99 & & Steel tape \\
\hline & & 04/08/2004 & 1400 & 58.30 & & Steel tape \\
\hline & & 07/29/2004 & 1349 & 62.10 & & Steel tape \\
\hline \multirow[t]{25}{*}{$47 \mathrm{~W} 88$} & 390545077554701 & $10 / 15 / 2002$ & 1500 & 20.84 & & Steel tape \\
\hline & & 01/29/2003 & 1320 & 18.63 & & Steel tape \\
\hline & & $04 / 22 / 2003$ & 1635 & 13.51 & & Steel tape \\
\hline & & 07/22/2003 & 1315 & 12.35 & & Steel tape \\
\hline & & $10 / 21 / 2003$ & 1455 & 13.45 & & Steel tape \\
\hline & & $02 / 05 / 2004$ & 1100 & 12.91 & & Steel tape \\
\hline & & 04/06/2004 & 1435 & 11.72 & & Steel tape \\
\hline & & 07/29/2004 & 0944 & 13.49 & & Steel tape \\
\hline & & 10/19/2004 & 1331 & 14.96 & & Steel tape \\
\hline & & 01/19/2005 & 1353 & 16.36 & & Steel tape \\
\hline & & 04/27/2005 & 1004 & 12.22 & & Steel tape \\
\hline & & 07/19/2005 & 0947 & 14.73 & & Steel tape \\
\hline & & 10/19/2005 & 1044 & 18.85 & & Steel tape \\
\hline & & 01/24/2006 & 1306 & 16.43 & & Steel tape \\
\hline & & 05/03/2006 & 1149 & 16.53 & & Steel tape \\
\hline & & 07/19/2006 & 0932 & 20.01 & & Steel tape \\
\hline & & 10/19/2006 & 1043 & 21.65 & & Steel tape \\
\hline & & $01 / 24 / 2007$ & 0930 & 15.65 & & Steel tape \\
\hline & & 04/17/2007 & 1125 & 14.07 & & Steel tape \\
\hline & & 07/17/2007 & 0945 & 18.29 & & Steel tape \\
\hline & & $10 / 17 / 2007$ & 1010 & 22.16 & & Steel tape \\
\hline & & 01/23/2008 & 1115 & 24.13 & & Steel tape \\
\hline & & 04/15/2008 & 1113 & 20.68 & & Steel tape \\
\hline & & 07/15/2008 & 1012 & 17.36 & & Steel tape \\
\hline & & $10 / 23 / 2008$ & 1346 & 22.07 & & Steel tape \\
\hline \multirow[t]{17}{*}{ 47W 89} & 390623077523501 & $10 / 24 / 2002$ & 0841 & 65.99 & & Steel tape \\
\hline & & 01/22/2003 & 1155 & 58.20 & & Steel tape \\
\hline & & $04 / 22 / 2003$ & 1440 & 51.30 & & Steel tape \\
\hline & & 07/22/2003 & 1125 & 52.98 & & Steel tape \\
\hline & & $10 / 21 / 2003$ & 1330 & 61.30 & & Steel tape \\
\hline & & 01/21/2004 & 1330 & 53.35 & & Steel tape \\
\hline & & $04 / 13 / 2004$ & 1403 & 51.83 & & Steel tape \\
\hline & & 07/29/2004 & 0906 & 58.71 & & Steel tape \\
\hline & & $10 / 20 / 2004$ & 0936 & 59.24 & & Steel tape \\
\hline & & 01/19/2005 & 1029 & 56.23 & & Steel tape \\
\hline & & 04/27/2005 & 1039 & 55.02 & & Steel tape \\
\hline & & 07/19/2005 & 1023 & 59.28 & & Steel tape \\
\hline & & 10/19/2005 & 1109 & 62.69 & & Steel tape \\
\hline & & $01 / 24 / 2006$ & 1512 & 60.22 & & Steel tape \\
\hline & & 05/02/2006 & 1321 & 59.32 & & Steel tape \\
\hline & & 07/19/2006 & 1014 & 60.80 & & Steel tape \\
\hline & & 10/19/2006 & 1115 & 62.46 & & Steel tape \\
\hline
\end{tabular}


Appendix 3. Water-level measurements from wells in Clarke County, Virginia, 2002-2008.-Continued

[ft blsd, feet below land surface datum. See figure 15 for location of wells]

\begin{tabular}{|c|c|c|c|c|c|c|}
\hline $\begin{array}{c}\text { USGS } \\
\text { local no. }\end{array}$ & $\begin{array}{l}\text { USGS } \\
\text { site no. }\end{array}$ & Date & Time & $\begin{array}{c}\text { Water level } \\
\text { (ft blsd) }\end{array}$ & $\begin{array}{c}\text { Water-level } \\
\text { status }\end{array}$ & $\begin{array}{c}\text { Measurement } \\
\text { method }\end{array}$ \\
\hline \multirow{8}{*}{\multicolumn{2}{|c|}{ 47W 89 (cont.) }} & $01 / 23 / 2007$ & 1110 & 57.79 & & Steel tape \\
\hline & & 04/17/2007 & 1205 & 54.15 & & Steel tape \\
\hline & & 07/17/2007 & 1020 & 59.73 & & Steel tape \\
\hline & & $10 / 17 / 2007$ & 1035 & 63.33 & & Steel tape \\
\hline & & 01/23/2008 & 1152 & 64.07 & & Steel tape \\
\hline & & 04/15/2008 & 1141 & 62.85 & & Steel tape \\
\hline & & 07/15/2008 & 1048 & 60.03 & & Steel tape \\
\hline & & $10 / 21 / 2008$ & 1235 & 61.20 & & Steel tape \\
\hline \multirow[t]{25}{*}{ 47W 90} & 390724077523201 & $10 / 22 / 2002$ & 1309 & 77.98 & & Steel tape \\
\hline & & 01/29/2003 & 1255 & 70.26 & & Steel tape \\
\hline & & 04/16/2003 & 1400 & 65.16 & & Steel tape \\
\hline & & 07/22/2003 & 1155 & 69.40 & & Steel tape \\
\hline & & $10 / 21 / 2003$ & 1140 & 72.15 & & Steel tape \\
\hline & & 01/21/2004 & 1425 & 72.30 & & Steel tape \\
\hline & & 04/06/2004 & 1005 & 68.48 & & Steel tape \\
\hline & & 07/29/2004 & 0828 & 69.48 & & Steel tape \\
\hline & & $10 / 20 / 2004$ & 0910 & 70.38 & & Steel tape \\
\hline & & 01/19/2005 & 1327 & 69.62 & & Electric tape \\
\hline & & 04/27/2005 & 1221 & 76.56 & & Steel tape \\
\hline & & 07/19/2005 & 1149 & 67.70 & & Steel tape \\
\hline & & $10 / 19 / 2005$ & 1500 & 74.75 & & Steel tape \\
\hline & & 01/24/2006 & 1526 & 68.78 & & Steel tape \\
\hline & & 05/02/2006 & 1351 & 69.90 & & Steel tape \\
\hline & & 07/19/2006 & 1441 & 73.76 & & Steel tape \\
\hline & & 10/19/2006 & 1221 & 74.16 & & Steel tape \\
\hline & & 01/23/2007 & 1418 & 68.14 & & Steel tape \\
\hline & & 04/17/2007 & 1319 & 65.99 & & Steel tape \\
\hline & & 07/17/2007 & 1153 & 69.86 & & Steel tape \\
\hline & & $10 / 17 / 2007$ & 1157 & 77.65 & & Steel tape \\
\hline & & 01/23/2008 & 1317 & 73.26 & & Steel tape \\
\hline & & 04/16/2008 & 1135 & 67.60 & & Steel tape \\
\hline & & 07/15/2008 & 1325 & 66.16 & & Steel tape \\
\hline & & $10 / 21 / 2008$ & 1438 & 74.05 & & Steel tape \\
\hline \multirow[t]{2}{*}{ 47W 91} & 390724077522901 & 01/29/2003 & 1235 & 88.36 & & Steel tape \\
\hline & & 04/16/2003 & 1350 & 84.56 & & Steel tape \\
\hline \multirow[t]{23}{*}{ 47W 92} & 390333077564101 & 01/30/2003 & 1730 & 27.08 & & Steel tape \\
\hline & & $04 / 24 / 2003$ & 1755 & 26.61 & & Steel tape \\
\hline & & 07/22/2003 & 1000 & 28.41 & & Steel tape \\
\hline & & $10 / 29 / 2003$ & 1145 & 27.58 & & Steel tape \\
\hline & & 02/05/2004 & 1040 & 26.53 & & Steel tape \\
\hline & & 04/13/2004 & 1205 & 22.67 & & Steel tape \\
\hline & & 07/29/2004 & 1145 & 34.34 & & Steel tape \\
\hline & & $10 / 25 / 2004$ & 1301 & 30.13 & & Steel tape \\
\hline & & 01/25/2005 & 1222 & 25.34 & & Steel tape \\
\hline & & 05/04/2005 & 1209 & 26.04 & & Steel tape \\
\hline & & 07/21/2005 & 1002 & 33.20 & & Steel tape \\
\hline & & $10 / 28 / 2005$ & 1039 & 33.88 & & Steel tape \\
\hline & & 01/24/2006 & 1327 & 26.93 & & Steel tape \\
\hline & & 05/03/2006 & 1054 & 26.43 & & Steel tape \\
\hline & & $10 / 26 / 2006$ & 1219 & 27.61 & & Steel tape \\
\hline & & 01/26/2007 & 1057 & 28.26 & & Steel tape \\
\hline & & 04/24/2007 & 1133 & 25.27 & & Steel tape \\
\hline & & 08/02/2007 & 1154 & 31.03 & & Steel tape \\
\hline & & $10 / 23 / 2007$ & 1558 & 35.14 & & Steel tape \\
\hline & & 01/31/2008 & 1339 & 34.44 & & Steel tape \\
\hline & & 04/18/2008 & 1224 & 38.31 & & Steel tape \\
\hline & & 07/17/2008 & 1404 & 32.21 & & Steel tape \\
\hline & & $10 / 23 / 2008$ & 1238 & 38.88 & & Steel tape \\
\hline
\end{tabular}


94 Hydrogeology and Groundwater Availability in Clarke County, Virginia

Appendix 3. Water-level measurements from wells in Clarke County, Virginia, 2002-2008.-Continued

[ft blsd, feet below land surface datum. See figure 15 for location of wells]

\begin{tabular}{|c|c|c|c|c|c|c|}
\hline $\begin{array}{c}\text { USGS } \\
\text { local no. }\end{array}$ & $\begin{array}{l}\text { USGS } \\
\text { site no. }\end{array}$ & Date & Time & $\begin{array}{c}\text { Water level } \\
\text { (ft blsd) }\end{array}$ & $\begin{array}{c}\text { Water-level } \\
\text { status }\end{array}$ & $\begin{array}{c}\text { Measurement } \\
\text { method }\end{array}$ \\
\hline \multirow[t]{23}{*}{ 47W 93} & 390150077585101 & $04 / 22 / 2003$ & 1705 & 47.23 & & Steel tape \\
\hline & & $07 / 21 / 2003$ & 1025 & 53.55 & & Steel tape \\
\hline & & $10 / 20 / 2003$ & 1425 & 59.57 & & Steel tape \\
\hline & & $01 / 21 / 2004$ & 1105 & 50.56 & & Steel tape \\
\hline & & $04 / 05 / 2004$ & 1130 & 48.93 & & Steel tape \\
\hline & & $07 / 27 / 2004$ & 1131 & 57.43 & & Steel tape \\
\hline & & $10 / 18 / 2004$ & 1157 & 60.02 & & Steel tape \\
\hline & & 01/18/2005 & 1358 & 51.54 & & Steel tape \\
\hline & & 05/02/2005 & 1151 & 49.44 & & Steel tape \\
\hline & & 07/18/2005 & 1142 & 57.72 & & Steel tape \\
\hline & & $10 / 17 / 2005$ & 1207 & 63.55 & & Steel tape \\
\hline & & $01 / 23 / 2006$ & 1236 & 52.68 & & Steel tape \\
\hline & & 05/01/2006 & 1157 & 57.81 & & Steel tape \\
\hline & & 07/17/2006 & 1351 & 58.86 & & Steel tape \\
\hline & & $10 / 18 / 2006$ & 1248 & 60.82 & & Steel tape \\
\hline & & $01 / 22 / 2007$ & 1325 & 51.81 & & Steel tape \\
\hline & & $04 / 16 / 2007$ & 1208 & 49.32 & & Steel tape \\
\hline & & 07/16/2007 & 1221 & 59.85 & & Steel tape \\
\hline & & $10 / 26 / 2007$ & 1151 & 67.98 & & Steel tape \\
\hline & & $01 / 22 / 2008$ & 1207 & 67.28 & & Steel tape \\
\hline & & $04 / 14 / 2008$ & 1208 & 58.04 & & Steel tape \\
\hline & & 07/14/2008 & 1116 & 64.41 & & Steel tape \\
\hline & & $10 / 20 / 2008$ & 1305 & 73.43 & & Steel tape \\
\hline \multirow[t]{25}{*}{$47 X 53$} & 390921077550801 & $10 / 24 / 2002$ & 1004 & 67.44 & & Steel tape \\
\hline & & 01/30/2003 & 0905 & 64.90 & & Steel tape \\
\hline & & $04 / 17 / 2003$ & 1045 & 58.45 & & Steel tape \\
\hline & & $07 / 22 / 2003$ & 1410 & 60.50 & & Steel tape \\
\hline & & $10 / 21 / 2003$ & 1530 & 62.12 & & Steel tape \\
\hline & & $01 / 21 / 2004$ & 1455 & 60.60 & & Steel tape \\
\hline & & 04/06/2004 & 1055 & 63.28 & & Steel tape \\
\hline & & 07/22/2004 & 1113 & 63.98 & & Steel tape \\
\hline & & $10 / 19 / 2004$ & 1434 & 64.35 & & Steel tape \\
\hline & & $01 / 25 / 2005$ & 0936 & 62.93 & & Steel tape \\
\hline & & 05/03/2005 & 1158 & 62.45 & & Steel tape \\
\hline & & 07/19/2005 & 1232 & 65.43 & & Steel tape \\
\hline & & $10 / 24 / 2005$ & 1240 & 67.10 & & Steel tape \\
\hline & & $01 / 26 / 2006$ & 1022 & 65.05 & & Steel tape \\
\hline & & $05 / 01 / 2006$ & 1444 & 66.59 & & Steel tape \\
\hline & & 07/20/2006 & 1047 & 66.69 & & Steel tape \\
\hline & & $10 / 19 / 2006$ & 1313 & 68.30 & & Steel tape \\
\hline & & $01 / 23 / 2007$ & 1523 & 66.04 & & Steel tape \\
\hline & & $04 / 17 / 2007$ & 1414 & 64.82 & & Steel tape \\
\hline & & 07/18/2007 & 0919 & 66.67 & & Steel tape \\
\hline & & $10 / 17 / 2007$ & 1331 & 67.28 & & Steel tape \\
\hline & & $01 / 23 / 2008$ & 1405 & 67.42 & & Steel tape \\
\hline & & $04 / 16 / 2008$ & 1238 & 67.36 & & Steel tape \\
\hline & & 07/15/2008 & 1417 & 65.76 & & Steel tape \\
\hline & & $10 / 21 / 2008$ & 1517 & 67.03 & & Steel tape \\
\hline \multirow[t]{8}{*}{ 47X 82} & 391203077585901 & $10 / 22 / 2002$ & 1634 & 16.56 & & Steel tape \\
\hline & & 01/30/2003 & 1420 & 12.13 & & Steel tape \\
\hline & & $04 / 15 / 2003$ & 1415 & 8.56 & & Steel tape \\
\hline & & 07/23/2003 & 1115 & 10.27 & & Steel tape \\
\hline & & $10 / 22 / 2003$ & 1205 & 11.85 & & Steel tape \\
\hline & & $01 / 22 / 2004$ & 1430 & 10.97 & & Steel tape \\
\hline & & $04 / 14 / 2004$ & 0910 & 8.00 & & Steel tape \\
\hline & & 07/28/2004 & 1427 & 12.57 & & Steel tape \\
\hline
\end{tabular}


Appendix 3. Water-level measurements from wells in Clarke County, Virginia, 2002-2008.-Continued

[ft blsd, feet below land surface datum. See figure 15 for location of wells]

\begin{tabular}{|c|c|c|c|c|c|c|}
\hline $\begin{array}{l}\text { USGS } \\
\text { local no. }\end{array}$ & $\begin{array}{l}\text { USGS } \\
\text { site no. }\end{array}$ & Date & Time & $\begin{array}{c}\text { Water level } \\
\text { (ft blsd) }\end{array}$ & $\begin{array}{c}\text { Water-level } \\
\text { status }\end{array}$ & $\begin{array}{c}\text { Measurement } \\
\text { method }\end{array}$ \\
\hline \multirow{21}{*}{\multicolumn{2}{|c|}{ 47X 82 (cont.) }} & $10 / 22 / 2004$ & 1037 & 12.52 & & Steel tape \\
\hline & & 01/27/2005 & 1142 & 12.29 & & Steel tape \\
\hline & & 05/04/2005 & 1332 & 11.78 & & Steel tape \\
\hline & & $07 / 26 / 2005$ & 1541 & 14.20 & & Steel tape \\
\hline & & 10/26/2005 & 1310 & 15.10 & & Steel tape \\
\hline & & 01/25/2006 & 1501 & 13.02 & & Steel tape \\
\hline & & 05/02/2006 & 1132 & 15.10 & & Steel tape \\
\hline & & $07 / 20 / 2006$ & 1216 & 14.82 & & Steel tape \\
\hline & & 10/19/2006 & 1430 & 15.02 & & Steel tape \\
\hline & & $01 / 24 / 2007$ & 1401 & 13.82 & & Steel tape \\
\hline & & 04/19/2007 & 1044 & 11.52 & & Steel tape \\
\hline & & $07 / 18 / 2007$ & 1411 & 14.61 & & Steel tape \\
\hline & & 10/17/2007 & 1508 & 16.17 & & Steel tape \\
\hline & & $11 / 08 / 2007$ & 1139 & 16.15 & & Steel tape \\
\hline & & $01 / 30 / 2008$ & 1452 & 15.58 & & Steel tape \\
\hline & & $02 / 21 / 2008$ & 1219 & 14.81 & & Steel tape \\
\hline & & $04 / 21 / 2008$ & 1103 & 9.74 & & Steel tape \\
\hline & & 05/08/2008 & 1732 & 11.90 & & Steel tape \\
\hline & & 07/17/2008 & 1040 & 13.05 & & Steel tape \\
\hline & & $07 / 31 / 2008$ & 1341 & 13.50 & & Steel tape \\
\hline & & $10 / 23 / 2008$ & 1202 & 15.27 & & Steel tape \\
\hline \multirow[t]{29}{*}{$47 X 83$} & 391203077585902 & $10 / 22 / 2002$ & 1649 & 16.67 & & Steel tape \\
\hline & & 01/30/2003 & 1405 & 10.75 & & Steel tape \\
\hline & & 04/15/2003 & 1355 & 5.24 & & Steel tape \\
\hline & & $07 / 23 / 2003$ & 1105 & 7.44 & & Steel tape \\
\hline & & $10 / 22 / 2003$ & 1215 & 10.23 & & Steel tape \\
\hline & & $01 / 22 / 2004$ & 1445 & 9.65 & & Steel tape \\
\hline & & $04 / 04 / 2004$ & 0905 & 4.32 & & Steel tape \\
\hline & & $07 / 28 / 2004$ & 1417 & 8.36 & & Steel tape \\
\hline & & $10 / 22 / 2004$ & 1030 & 11.46 & & Steel tape \\
\hline & & 01/27/2005 & 1133 & 10.96 & & Steel tape \\
\hline & & 05/04/2005 & 1323 & 9.82 & & Steel tape \\
\hline & & $07 / 26 / 2005$ & 1535 & 13.73 & & Steel tape \\
\hline & & $10 / 26 / 2005$ & 1305 & 15.14 & & Steel tape \\
\hline & & $01 / 25 / 2006$ & 1456 & 12.04 & & Steel tape \\
\hline & & 05/02/2006 & 1128 & 15.00 & & Steel tape \\
\hline & & 07/20/2006 & 1212 & 14.58 & & Steel tape \\
\hline & & $10 / 19 / 2006$ & 1429 & 15.04 & & Steel tape \\
\hline & & 01/24/2007 & 1400 & 13.18 & & Steel tape \\
\hline & & 04/19/2007 & 1037 & 9.43 & & Steel tape \\
\hline & & $07 / 18 / 2007$ & 1414 & 16.40 & & Steel tape \\
\hline & & $10 / 17 / 2007$ & 1505 & 16.15 & & Steel tape \\
\hline & & $11 / 08 / 2007$ & 1152 & 16.23 & & Steel tape \\
\hline & & 01/30/2008 & 1442 & 15.64 & & Steel tape \\
\hline & & $02 / 21 / 2008$ & 1202 & 14.82 & & Steel tape \\
\hline & & $04 / 21 / 2008$ & 1101 & 11.02 & & Steel tape \\
\hline & & 05/08/2008 & 1734 & 15.18 & & Steel tape \\
\hline & & $07 / 17 / 2008$ & 1037 & 12.09 & & Steel tape \\
\hline & & 07/31/2008 & 1339 & 12.63 & & Steel tape \\
\hline & & $10 / 23 / 2008$ & 1204 & 15.29 & & Steel tape \\
\hline \multirow[t]{5}{*}{ 47X 84} & 390805077552101 & $10 / 24 / 2002$ & 1026 & 45.15 & & Steel tape \\
\hline & & 01/30/2003 & 0835 & 43.07 & & Steel tape \\
\hline & & 04/17/2003 & 1115 & 37.88 & & Steel tape \\
\hline & & $07 / 22 / 2003$ & 1440 & 39.21 & & Steel tape \\
\hline & & $10 / 23 / 2003$ & 1125 & 41.08 & & Steel tape \\
\hline
\end{tabular}


96 Hydrogeology and Groundwater Availability in Clarke County, Virginia

Appendix 3. Water-level measurements from wells in Clarke County, Virginia, 2002-2008.-Continued

[ft blsd, feet below land surface datum. See figure 15 for location of wells]

\begin{tabular}{|c|c|c|c|c|c|c|}
\hline $\begin{array}{c}\text { USGS } \\
\text { local no. }\end{array}$ & $\begin{array}{l}\text { USGS } \\
\text { site no. }\end{array}$ & Date & Time & $\begin{array}{c}\text { Water level } \\
\text { (ft blsd) }\end{array}$ & $\begin{array}{c}\text { Water-level } \\
\text { status }\end{array}$ & $\begin{array}{c}\text { Measurement } \\
\text { method }\end{array}$ \\
\hline \multirow[t]{20}{*}{$47 \mathrm{X} 84$ (cont.) } & & $02 / 05 / 2004$ & 1220 & 41.39 & & Steel tape \\
\hline & & 04/06/2004 & 1120 & 38.52 & & Steel tape \\
\hline & & $07 / 22 / 2004$ & 1131 & 43.19 & & Steel tape \\
\hline & & $10 / 20 / 2004$ & 1040 & 43.29 & & Steel tape \\
\hline & & $01 / 21 / 2005$ & 1109 & 38.52 & & Steel tape \\
\hline & & 05/03/2005 & 1216 & 41.90 & & Steel tape \\
\hline & & 07/19/2005 & 1248 & 42.49 & & Steel tape \\
\hline & & $10 / 24 / 2005$ & 1307 & 44.91 & & Steel tape \\
\hline & & 01/26/2006 & 1037 & 42.39 & & Steel tape \\
\hline & & 05/01/2006 & 1501 & 44.85 & & Steel tape \\
\hline & & 07/19/2006 & 1454 & 45.31 & & Steel tape \\
\hline & & 10/19/2006 & 1331 & 45.15 & & Steel tape \\
\hline & & 01/23/2007 & 1459 & 44.44 & & Steel tape \\
\hline & & 04/17/2007 & 1506 & 42.08 & & Steel tape \\
\hline & & 07/18/2007 & 0947 & 45.12 & & Steel tape \\
\hline & & $10 / 17 / 2007$ & 1345 & 45.75 & & Steel tape \\
\hline & & 01/23/2008 & 1428 & 45.93 & & Steel tape \\
\hline & & 04/16/2008 & 1304 & 46.42 & & Steel tape \\
\hline & & 07/15/2008 & 1438 & 44.28 & & Steel tape \\
\hline & & $10 / 22 / 2008$ & 1256 & 45.55 & & Steel tape \\
\hline \multirow[t]{25}{*}{$47 X 85$} & 390917077535301 & $10 / 24 / 2002$ & 0935 & 63.48 & & Steel tape \\
\hline & & 01/30/2003 & 0940 & 57.03 & & Steel tape \\
\hline & & 04/17/2003 & 1020 & 48.90 & & Steel tape \\
\hline & & 07/22/2003 & 1350 & 51.46 & & Steel tape \\
\hline & & $10 / 23 / 2003$ & 1055 & 53.86 & & Steel tape \\
\hline & & $02 / 05 / 2004$ & 1153 & 53.66 & & Steel tape \\
\hline & & 04/06/2004 & 1040 & 53.58 & & Steel tape \\
\hline & & $07 / 22 / 2004$ & 1055 & 54.67 & & Steel tape \\
\hline & & $10 / 19 / 2004$ & 1417 & 57.68 & & Steel tape \\
\hline & & 01/25/2005 & 0949 & 54.00 & & Steel tape \\
\hline & & 05/03/2005 & 1141 & 52.46 & & Steel tape \\
\hline & & 07/19/2005 & 1213 & 58.21 & & Steel tape \\
\hline & & $10 / 24 / 2005$ & 1222 & 62.12 & & Steel tape \\
\hline & & 01/26/2006 & 1007 & 58.10 & & Steel tape \\
\hline & & 05/01/2006 & 1430 & 61.53 & & Steel tape \\
\hline & & 07/20/2006 & 1034 & 61.85 & & Steel tape \\
\hline & & $10 / 19 / 2006$ & 1245 & 62.02 & & Steel tape \\
\hline & & 01/24/2007 & 1007 & 59.10 & & Steel tape \\
\hline & & 04/17/2007 & 1355 & 55.74 & & Steel tape \\
\hline & & 07/17/2007 & 1233 & 61.61 & & Steel tape \\
\hline & & $10 / 17 / 2007$ & 1314 & 63.73 & & Steel tape \\
\hline & & 01/23/2008 & 1345 & 63.46 & & Steel tape \\
\hline & & 04/16/2008 & 1218 & 61.75 & & Steel tape \\
\hline & & 07/15/2008 & 1349 & 58.40 & & Steel tape \\
\hline & & $10 / 21 / 2008$ & 1502 & 62.51 & & Steel tape \\
\hline \multirow[t]{11}{*}{$47 X 86$} & 391109077592801 & $10 / 24 / 2002$ & 1155 & 34.90 & & Steel tape \\
\hline & & 01/30/2003 & 1125 & 33.56 & & Steel tape \\
\hline & & 04/15/2003 & 1310 & 10.80 & & Steel tape \\
\hline & & 07/23/2003 & 0940 & 16.59 & & Steel tape \\
\hline & & $10 / 22 / 2003$ & 1130 & 23.28 & & Steel tape \\
\hline & & 02/05/2004 & 1445 & 21.13 & & Steel tape \\
\hline & & 04/07/2004 & 1132 & 18.19 & & Steel tape \\
\hline & & 07/27/2004 & 1423 & 22.94 & & Steel tape \\
\hline & & $10 / 20 / 2004$ & 1349 & 26.75 & & Steel tape \\
\hline & & 01/27/2005 & 1056 & 25.95 & & Steel tape \\
\hline & & 05/03/2005 & 1515 & 24.06 & & Steel tape \\
\hline
\end{tabular}


Appendix 3. Water-level measurements from wells in Clarke County, Virginia, 2002-2008.-Continued

[ft blsd, feet below land surface datum. See figure 15 for location of wells]

\begin{tabular}{|c|c|c|c|c|c|c|}
\hline $\begin{array}{c}\text { USGS } \\
\text { local no. }\end{array}$ & $\begin{array}{l}\text { USGS } \\
\text { site no. }\end{array}$ & Date & Time & $\begin{array}{l}\text { Water level } \\
\text { (ft blsd) }\end{array}$ & $\begin{array}{c}\text { Water-level } \\
\text { status }\end{array}$ & $\begin{array}{c}\text { Measurement } \\
\text { method }\end{array}$ \\
\hline \multirow[t]{14}{*}{ 47X 86 (cont.) } & & $07 / 20 / 2005$ & 1358 & 29.78 & & Steel tape \\
\hline & & $10 / 24 / 2005$ & 1439 & 34.45 & & Steel tape \\
\hline & & $01 / 25 / 2006$ & 1421 & 32.40 & & Electric tape \\
\hline & & 05/02/2006 & 1243 & 32.17 & & Steel tape \\
\hline & & 07/20/2006 & 1105 & 33.66 & & Steel tape \\
\hline & & 10/19/2006 & 1457 & 32.96 & & Steel tape \\
\hline & & $01 / 24 / 2007$ & 1311 & 28.82 & & Steel tape \\
\hline & & 04/18/2007 & 1451 & 23.88 & & Steel tape \\
\hline & & 07/18/2007 & 1253 & 31.52 & & Steel tape \\
\hline & & 10/17/2007 & 1552 & 37.82 & & Electric tape \\
\hline & & 01/23/2008 & 1518 & 34.30 & & Steel tape \\
\hline & & 04/15/2008 & 1608 & 32.09 & & Steel tape \\
\hline & & 07/16/2008 & 1337 & 26.79 & & Steel tape \\
\hline & & $10 / 23 / 2008$ & 1040 & 34.36 & & Steel tape \\
\hline 47X 87 & 391159077592201 & $10 / 21 / 2002$ & 1520 & 41.03 & & Steel tape \\
\hline \multirow[t]{17}{*}{$47 X 89$} & 391050077591701 & $10 / 21 / 2004$ & 1205 & 21.21 & & Steel tape \\
\hline & & 01/27/2005 & 1120 & 19.98 & & Steel tape \\
\hline & & 05/03/2005 & 1555 & 16.89 & & Steel tape \\
\hline & & 07/20/2005 & 1340 & 23.72 & & Steel tape \\
\hline & & $10 / 24 / 2005$ & 1502 & 28.11 & & Steel tape \\
\hline & & 01/25/2006 & 1434 & 21.36 & & Steel tape \\
\hline & & 05/02/2006 & 1253 & 27.76 & & Steel tape \\
\hline & & 07/20/2006 & 1116 & 25.85 & & Steel tape \\
\hline & & 10/19/2006 & 1537 & 27.54 & & Steel tape \\
\hline & & 01/24/2007 & 1325 & 23.90 & & Steel tape \\
\hline & & 04/18/2007 & 1523 & 16.69 & & Steel tape \\
\hline & & 07/18/2007 & 1306 & 26.66 & & Steel tape \\
\hline & & 10/17/2007 & 1613 & 29.99 & & Steel tape \\
\hline & & 01/23/2008 & 1535 & 29.48 & & Steel tape \\
\hline & & 04/15/2008 & 1631 & 26.62 & & Steel tape \\
\hline & & 07/16/2008 & 1421 & 21.54 & & Steel tape \\
\hline & & $10 / 23 / 2008$ & 1056 & 28.24 & & Steel tape \\
\hline \multirow[t]{24}{*}{$48 \times 20$} & 390743077504501 & $10 / 22 / 2002$ & 1355 & 32.41 & & Steel tape \\
\hline & & $01 / 24 / 2003$ & 1029 & 30.59 & & Steel tape \\
\hline & & 04/15/2003 & 0839 & 25.74 & & Steel tape \\
\hline & & 07/28/2003 & 1120 & 30.24 & & Steel tape \\
\hline & & $10 / 29 / 2003$ & 1330 & 31.97 & & Steel tape \\
\hline & & $01 / 22 / 2004$ & 1500 & 32.73 & & Steel tape \\
\hline & & 04/06/2004 & 1532 & 29.56 & & Steel tape \\
\hline & & 07/14/2004 & 0925 & 30.97 & & Steel tape \\
\hline & & $10 / 19 / 2004$ & 0829 & 31.01 & & Steel tape \\
\hline & & 01/19/2005 & 1021 & 25.70 & & Electric tape \\
\hline & & 04/26/2005 & 1642 & 28.33 & & Steel tape \\
\hline & & 07/20/2005 & 0850 & 29.12 & & Steel tape \\
\hline & & 10/19/2005 & 1204 & 30.57 & & Steel tape \\
\hline & & $01 / 24 / 2006$ & 1128 & 25.80 & & Steel tape \\
\hline & & 05/03/2006 & 1510 & 30.71 & & Steel tape \\
\hline & & 07/19/2006 & 1420 & 29.67 & & Steel tape \\
\hline & & 10/23/2006 & 1551 & 28.73 & & Steel tape \\
\hline & & 01/26/2007 & 1016 & 28.33 & & Steel tape \\
\hline & & 04/26/2007 & 1539 & 27.83 & & Steel tape \\
\hline & & 07/20/2007 & 1009 & 32.15 & & Steel tape \\
\hline & & 07/25/2007 & 1507 & 32.50 & & Steel tape \\
\hline & & $10 / 16 / 2007$ & 1021 & 36.63 & & Steel tape \\
\hline & & $10 / 22 / 2007$ & 1407 & 37.16 & & Steel tape \\
\hline & & $11 / 07 / 2007$ & 1444 & 37.10 & & Steel tape \\
\hline
\end{tabular}




\section{Hydrogeology and Groundwater Availability in Clarke County, Virginia}

Appendix 3. Water-level measurements from wells in Clarke County, Virginia, 2002-2008._Continued

[ft blsd, feet below land surface datum. See figure 15 for location of wells]

\begin{tabular}{|c|c|c|c|c|c|c|}
\hline $\begin{array}{c}\text { USGS } \\
\text { local no. }\end{array}$ & $\begin{array}{l}\text { USGS } \\
\text { site no. }\end{array}$ & Date & Time & $\begin{array}{c}\text { Water level } \\
\text { (ft blsd) }\end{array}$ & $\begin{array}{c}\text { Water-level } \\
\text { status }\end{array}$ & $\begin{array}{c}\text { Measurement } \\
\text { method }\end{array}$ \\
\hline \multirow{7}{*}{\multicolumn{2}{|c|}{$48 X 20$ (cont.) }} & $11 / 09 / 2007$ & 1250 & 37.14 & & Steel tape \\
\hline & & $01 / 25 / 2008$ & 1158 & 35.13 & & Steel tape \\
\hline & & $02 / 20 / 2008$ & 1512 & 30.81 & & Steel tape \\
\hline & & $04 / 15 / 2008$ & 1327 & 31.76 & & Steel tape \\
\hline & & 07/15/2008 & 1211 & 32.63 & & Steel tape \\
\hline & & 07/31/2008 & 0951 & 32.72 & & Steel tape \\
\hline & & $10 / 21 / 2008$ & 1344 & 34.72 & & Steel tape \\
\hline \multirow{29}{*}{\multicolumn{2}{|c|}{$48 X 21 \quad 390733077503601$}} & $10 / 22 / 2002$ & 1519 & 59.98 & & Steel tape \\
\hline & & $01 / 24 / 2003$ & 0950 & 58.11 & & Steel tape \\
\hline & & $04 / 15 / 2003$ & 0919 & 45.90 & & Steel tape \\
\hline & & 07/28/2003 & 1145 & 49.02 & & Steel tape \\
\hline & & $11 / 06 / 2003$ & 1140 & 48.14 & & Steel tape \\
\hline & & $01 / 21 / 2004$ & 1400 & 48.59 & & Steel tape \\
\hline & & $04 / 06 / 2004$ & 0930 & 38.14 & & Steel tape \\
\hline & & $07 / 14 / 2004$ & 0957 & 50.63 & & Steel tape \\
\hline & & $10 / 19 / 2004$ & 0855 & 54.54 & & Steel tape \\
\hline & & 01/19/2005 & 1047 & 44.13 & & Electric tape \\
\hline & & $04 / 26 / 2005$ & 1611 & 50.78 & & Steel tape \\
\hline & & 07/20/2005 & 0912 & 51.76 & & Steel tape \\
\hline & & $10 / 19 / 2005$ & 1224 & 56.56 & & Steel tape \\
\hline & & $01 / 24 / 2006$ & 1110 & 48.08 & & Steel tape \\
\hline & & $05 / 02 / 2006$ & 1335 & 53.82 & & Steel tape \\
\hline & & 07/19/2006 & 1401 & 54.56 & & Steel tape \\
\hline & & $10 / 19 / 2006$ & 1204 & 52.81 & & Steel tape \\
\hline & & $01 / 26 / 2007$ & 1001 & 45.68 & & Steel tape \\
\hline & & 04/26/2007 & 1521 & 52.74 & & Steel tape \\
\hline & & 07/18/2007 & 1120 & 53.62 & & Steel tape \\
\hline & & $10 / 16 / 2007$ & 1003 & 61.71 & & Steel tape \\
\hline & & $10 / 22 / 2007$ & 1603 & 62.90 & & Steel tape \\
\hline & & $11 / 07 / 2007$ & 1342 & 63.86 & & Steel tape \\
\hline & & $01 / 25 / 2008$ & 1309 & 65.20 & & Steel tape \\
\hline & & $02 / 20 / 2008$ & 1552 & 59.99 & & Steel tape \\
\hline & & $04 / 15 / 2008$ & 1244 & 59.79 & & Steel tape \\
\hline & & 07/15/2008 & 1145 & 54.87 & & Steel tape \\
\hline & & 07/31/2008 & 1039 & 55.62 & & Steel tape \\
\hline & & $10 / 21 / 2008$ & 1321 & 59.55 & & Steel tape \\
\hline
\end{tabular}


Appendix 4. Discharge and water-quality field properties from streams and springs in Clarke County, Virginia, 2003-2008.

$\left[\mathrm{ft}^{3} / \mathrm{s}\right.$, cubic feet per second; gal $/ \mathrm{min}$, gallons per minute; ft, feet; Temp., water temperature; ${ }^{\circ} \mathrm{C}$, degrees Celsius; Sp. Cond., specific conductance at $25^{\circ} \mathrm{C}$; $\mu \mathrm{S} / \mathrm{cm}$, microsiemens per centimeter; $\mathrm{O}_{2}$, dissolved oxygen; $\mathrm{mg} / \mathrm{L}$, milligrams per liter; $\mathrm{pH}$ in standard units; nd, not determined. Discharge measurement method: F, flume; ADV, acoustic doppler velocimeter; AA, standard AA velocity meter; P, pygmy velocity meter; V, volumetric. See figures 15 and 28 for location of stream and spring measurement sites]

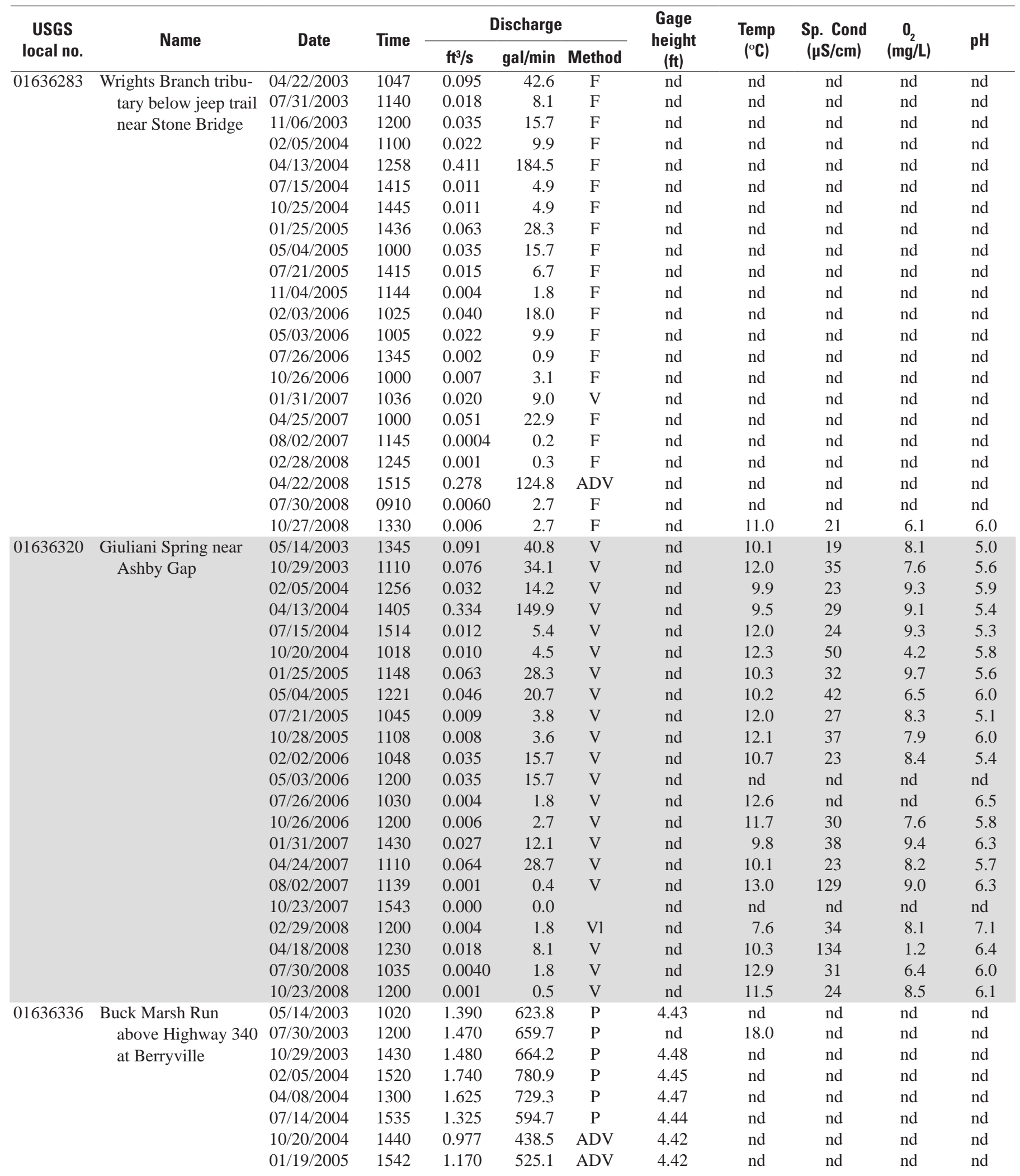


Appendix 4. Discharge and water-quality field properties from streams and springs in Clarke County, Virginia, 2003-2008.-Continued

$\left[\mathrm{ft}^{3} / \mathrm{s}\right.$, cubic feet per second; gal $/ \mathrm{min}$, gallons per minute; ft, feet; Temp., water temperature; ${ }^{\circ} \mathrm{C}$, degrees Celsius; Sp. Cond., specific conductance at $25{ }^{\circ} \mathrm{C}$; $\mu \mathrm{S} / \mathrm{cm}$, microsiemens per centimeter; $\mathrm{O}_{2}$, dissolved oxygen; $\mathrm{mg} / \mathrm{L}$, milligrams per liter; $\mathrm{pH}$ in standard units; nd, not determined. Discharge measurement method: F, flume; ADV, acoustic doppler velocimeter; AA, standard AA velocity meter; P, pygmy velocity meter; V, volumetric. See figures 15 and 28 for location of stream and spring measurement sites]

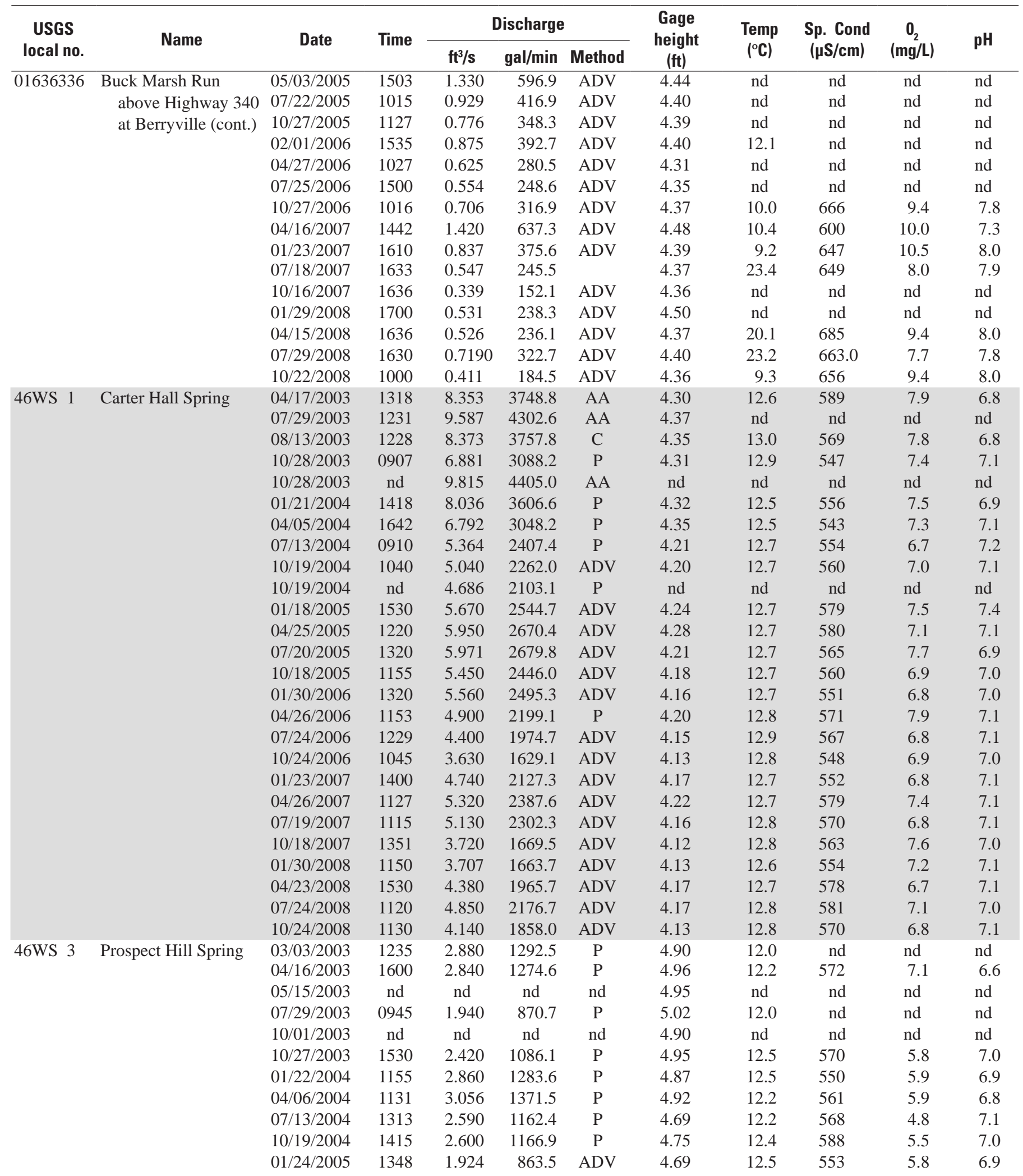


Appendix 4. Discharge and water-quality field properties from streams and springs in Clarke County, Virginia, 2003-2008.—Continued

$\left[\mathrm{ft}^{3} / \mathrm{s}\right.$, cubic feet per second; gal $/ \mathrm{min}$, gallons per minute; $\mathrm{ft}$, feet; Temp., water temperature; ${ }^{\circ} \mathrm{C}$, degrees Celsius; Sp. Cond., specific conductance at $25^{\circ} \mathrm{C}$; $\mu \mathrm{S} / \mathrm{cm}$, microsiemens per centimeter; $\mathrm{O}_{2}$, dissolved oxygen; $\mathrm{mg} / \mathrm{L}$, milligrams per liter; $\mathrm{pH}$ in standard units; nd, not determined. Discharge measurement method: F, flume; ADV, acoustic doppler velocimeter; AA, standard AA velocity meter; P, pygmy velocity meter; V, volumetric. See figures 15 and 28 for location of stream and spring measurement sites]

\begin{tabular}{|c|c|c|c|c|c|c|c|c|c|c|c|}
\hline $\begin{array}{c}\text { USGS } \\
\text { local no. }\end{array}$ & Name & Date & Time & \multicolumn{3}{|c|}{ Discharge } & $\begin{array}{c}\text { Gage } \\
\text { height } \\
\text { (ft) }\end{array}$ & $\begin{array}{c}\text { Temp } \\
\left({ }^{\circ} \mathrm{C}\right)\end{array}$ & $\begin{array}{l}\text { Sp. Cond } \\
(\mu \mathrm{S} / \mathrm{cm})\end{array}$ & $\begin{array}{c}0_{2} \\
\text { (mg/L) }\end{array}$ & $\mathrm{pH}$ \\
\hline \multirow[t]{9}{*}{ 46WS 3} & Prospect Hill Spring & $04 / 28 / 2005$ & 1245 & 2.021 & 907.0 & ADV & 4.77 & 12.3 & 595 & 7.6 & 7.0 \\
\hline & & 07/25/2005 & nd & nd & nd & & 4.71 & 12.2 & 586 & 6.1 & 6.9 \\
\hline & & $10 / 18 / 2005$ & 1536 & 1.250 & 561.0 & ADV & 4.53 & 12.4 & 605 & 6.8 & 6.8 \\
\hline & & 01/31/2006 & 1433 & 1.753 & 786.7 & ADV & 4.81 & 12.6 & 591 & 6.5 & 6.8 \\
\hline & & $10 / 25 / 2006$ & 1351 & 1.570 & 704.6 & ADV & 4.67 & 12.6 & 615 & 5.6 & 6.8 \\
\hline & & 02/01/2007 & 1219 & 1.740 & 780.9 & $\mathrm{ADV}$ & nd & 12.7 & 632 & 5.4 & 6.9 \\
\hline & & $04 / 25 / 2007$ & 1200 & 1.670 & 749.5 & ADV & nd & 12.4 & 601 & 6.5 & 6.9 \\
\hline & & 07/19/2007 & 1409 & 1.200 & 538.6 & ADV & nd & 12.3 & 613 & 5.1 & 6.9 \\
\hline & & $10 / 18 / 2007$ & 1545 & 1.450 & 650.8 & ADV & nd & 12.5 & 611 & 7.4 & 6.8 \\
\hline \multirow[t]{15}{*}{ 46WS 5} & Huntingdon Spring & 05/13/2003 & 1435 & 1.040 & 466.8 & $\mathrm{P}$ & nd & 12.2 & 542 & 5.1 & 6.9 \\
\hline & & $02 / 04 / 2004$ & 1110 & 1.030 & 462.3 & $\mathrm{P}$ & nd & 12.3 & 521 & 5.6 & 7.0 \\
\hline & & $04 / 14 / 2004$ & 1225 & 1.291 & 579.4 & $\mathrm{P}$ & nd & 11.8 & 524 & 5.2 & 7.2 \\
\hline & & 07/13/2004 & 1115 & 0.536 & 240.6 & $P$ & nd & 12.9 & 552 & 4.6 & 7.0 \\
\hline & & $10 / 21 / 2004$ & 1350 & 0.435 & 195.2 & $\mathrm{ADV}$ & nd & 13.7 & 571 & 6.1 & 7.0 \\
\hline & & 01/26/2005 & 0939 & 0.524 & 235.2 & $\mathrm{ADV}$ & nd & 12.8 & 592 & 5.2 & 7.5 \\
\hline & & 05/02/2005 & 1224 & 0.613 & 275.1 & $\mathrm{ADV}$ & nd & 12.2 & 585 & 5.7 & 7.0 \\
\hline & & 07/20/2005 & 1455 & 0.422 & 189.4 & $\mathrm{ADV}$ & nd & 12.5 & 587 & 4.6 & 6.7 \\
\hline & & 08/11/2005 & 1345 & 0.293 & 131.5 & ADV & nd & 12.7 & 592 & 3.1 & 6.9 \\
\hline & & $10 / 26 / 2005$ & 1420 & 0.055 & 24.7 & ADV & nd & 12.4 & 599 & 1.9 & 7.0 \\
\hline & & 02/02/2006 & 1256 & 0.834 & 374.3 & ADV & nd & 12.9 & 570 & 5.8 & 7.0 \\
\hline & & $04 / 26 / 2006$ & 1550 & 0.284 & 127.5 & $\mathrm{P}$ & nd & 12.5 & 604 & 5.9 & 7.0 \\
\hline & & 04/15/2008 & 1314 & 0.371 & 166.5 & ADV & nd & 12.4 & 690 & 6.6 & 7.0 \\
\hline & & 07/29/2008 & 1207 & 0.5080 & 228.0 & $\mathrm{ADV}$ & nd & 12.7 & 595 & 5.2 & 7.2 \\
\hline & & $10 / 21 / 2008$ & 1320 & 0.000 & 0.0 & & nd & nd & nd & nd & nd \\
\hline \multirow[t]{14}{*}{ 46WS 7} & Borden Spring & 08/11/2005 & 1000 & 1.306 & 586.1 & ADV & 4.14 & 12.6 & 507 & 6.7 & 7.0 \\
\hline & & $10 / 20 / 2005$ & 1110 & 1.315 & 590.2 & ADV & 4.14 & 12.7 & 513 & 7.1 & 7.1 \\
\hline & & 02/01/2006 & 1115 & 1.050 & 471.2 & ADV & 4.17 & 12.8 & 493 & 7.1 & 7.3 \\
\hline & & $04 / 26 / 2006$ & 1506 & 1.100 & 493.7 & $\mathrm{P}$ & 4.14 & 12.7 & 518 & 6.6 & 7.1 \\
\hline & & 07/18/2006 & 0933 & 0.905 & 406.2 & ADV & 4.17 & 12.7 & 496 & 7.3 & 7.1 \\
\hline & & $11 / 02 / 2006$ & 1400 & 0.945 & 424.1 & ADV & 4.15 & 12.8 & 507 & 7.0 & 7.1 \\
\hline & & 01/30/2007 & 1500 & 1.030 & 462.3 & ADV & 4.14 & 12.5 & 505 & 7.1 & 7.3 \\
\hline & & 04/23/2007 & 1426 & 1.260 & 565.5 & ADV & 4.17 & 12.7 & 511 & 7.1 & 7.2 \\
\hline & & 07/18/2007 & 1341 & 0.946 & 424.6 & ADV & 4.14 & 12.8 & 514 & 6.8 & 7.1 \\
\hline & & $10 / 17 / 2007$ & 1513 & 0.745 & 334.4 & ADV & 4.12 & nd & nd & nd & nd \\
\hline & & 01/29/2008 & 1515 & 0.906 & 406.6 & ADV & 4.14 & 12.7 & 504 & 6.8 & 7.0 \\
\hline & & 04/17/2008 & 1709 & 0.929 & 416.9 & $\mathrm{ADV}$ & nd & 12.8 & 514 & 7.1 & 7.2 \\
\hline & & 07/29/2008 & 1435 & 1.2200 & 547.5 & ADV & 4.16 & 12.7 & 515 & 6.9 & 7.2 \\
\hline & & $10 / 20 / 2008$ & 1620 & 1.210 & 543.0 & ADV & nd & 12.7 & 522 & 6.9 & 7.2 \\
\hline
\end{tabular}


Appendix 4. Discharge and water-quality field properties from streams and springs in Clarke County, Virginia, 2003-2008.-Continued

$\left[\mathrm{ft} / \mathrm{s}\right.$, cubic feet per second; gal $/ \mathrm{min}$, gallons per minute; ft, feet; Temp., water temperature; ${ }^{\circ} \mathrm{C}$, degrees Celsius; Sp. Cond., specific conductance at $25^{\circ} \mathrm{C}$; $\mu \mathrm{S} / \mathrm{cm}$, microsiemens per centimeter; $\mathrm{O}_{2}$, dissolved oxygen; $\mathrm{mg} / \mathrm{L}$, milligrams per liter; $\mathrm{pH}$ in standard units; nd, not determined. Discharge measurement method: F, flume; ADV, acoustic doppler velocimeter; AA, standard AA velocity meter; P, pygmy velocity meter; V, volumetric. See figures 15 and 28 for location of stream and spring measurement sites]

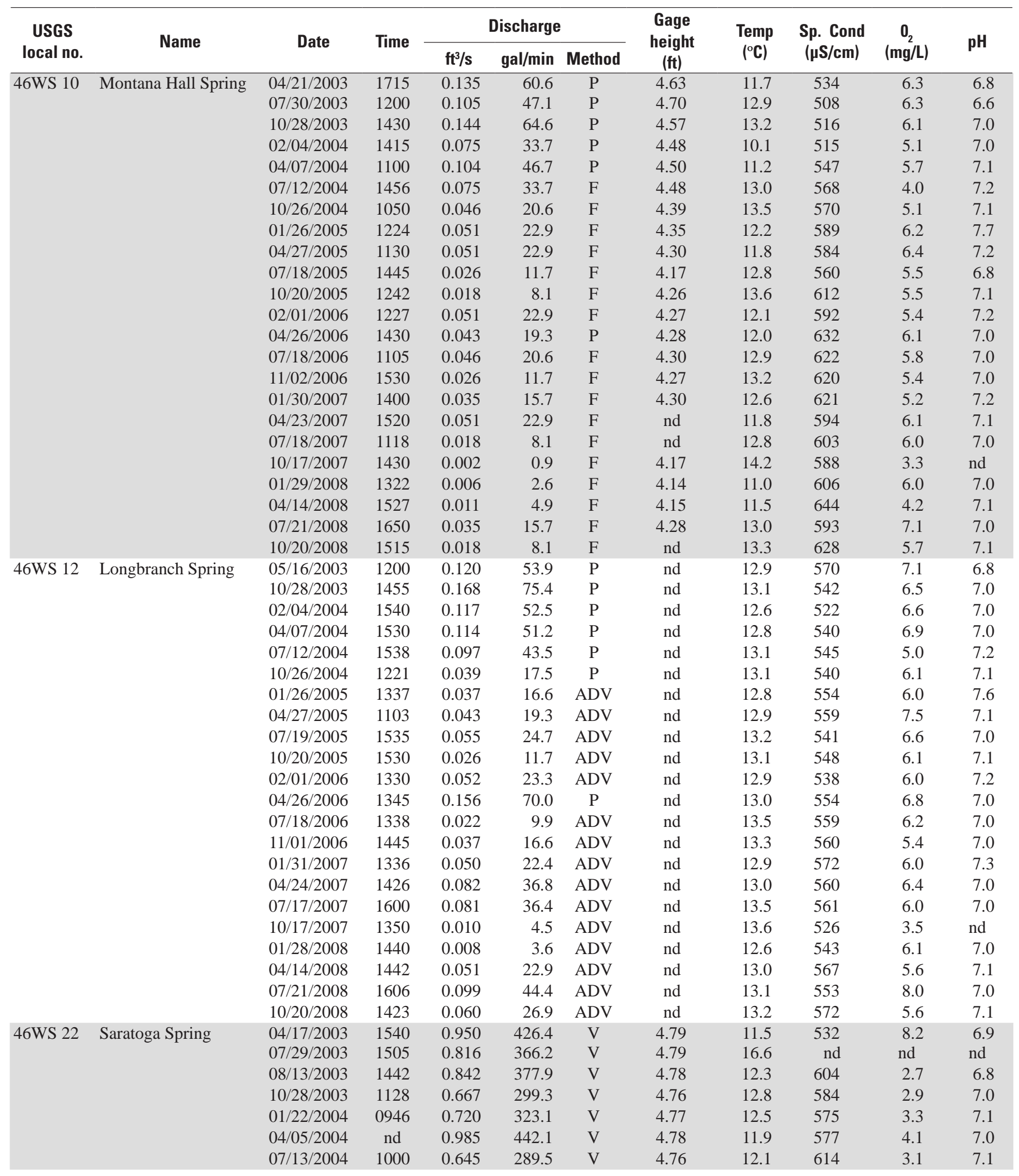


Appendix 4. Discharge and water-quality field properties from streams and springs in Clarke County, Virginia, 2003-2008._Continued

$\left[\mathrm{ft}^{3} / \mathrm{s}\right.$, cubic feet per second; gal $/ \mathrm{min}$, gallons per minute; ft, feet; Temp., water temperature; ${ }^{\circ} \mathrm{C}$, degrees Celsius; Sp. Cond., specific conductance at $25^{\circ} \mathrm{C}$; $\mu \mathrm{S} / \mathrm{cm}$, microsiemens per centimeter; $\mathrm{O}_{2}$, dissolved oxygen; $\mathrm{mg} / \mathrm{L}$, milligrams per liter; $\mathrm{pH}$ in standard units; nd, not determined. Discharge measurement method: F, flume; ADV, acoustic doppler velocimeter; AA, standard AA velocity meter; P, pygmy velocity meter; V, volumetric. See figures 15 and 28 for location of stream and spring measurement sites]

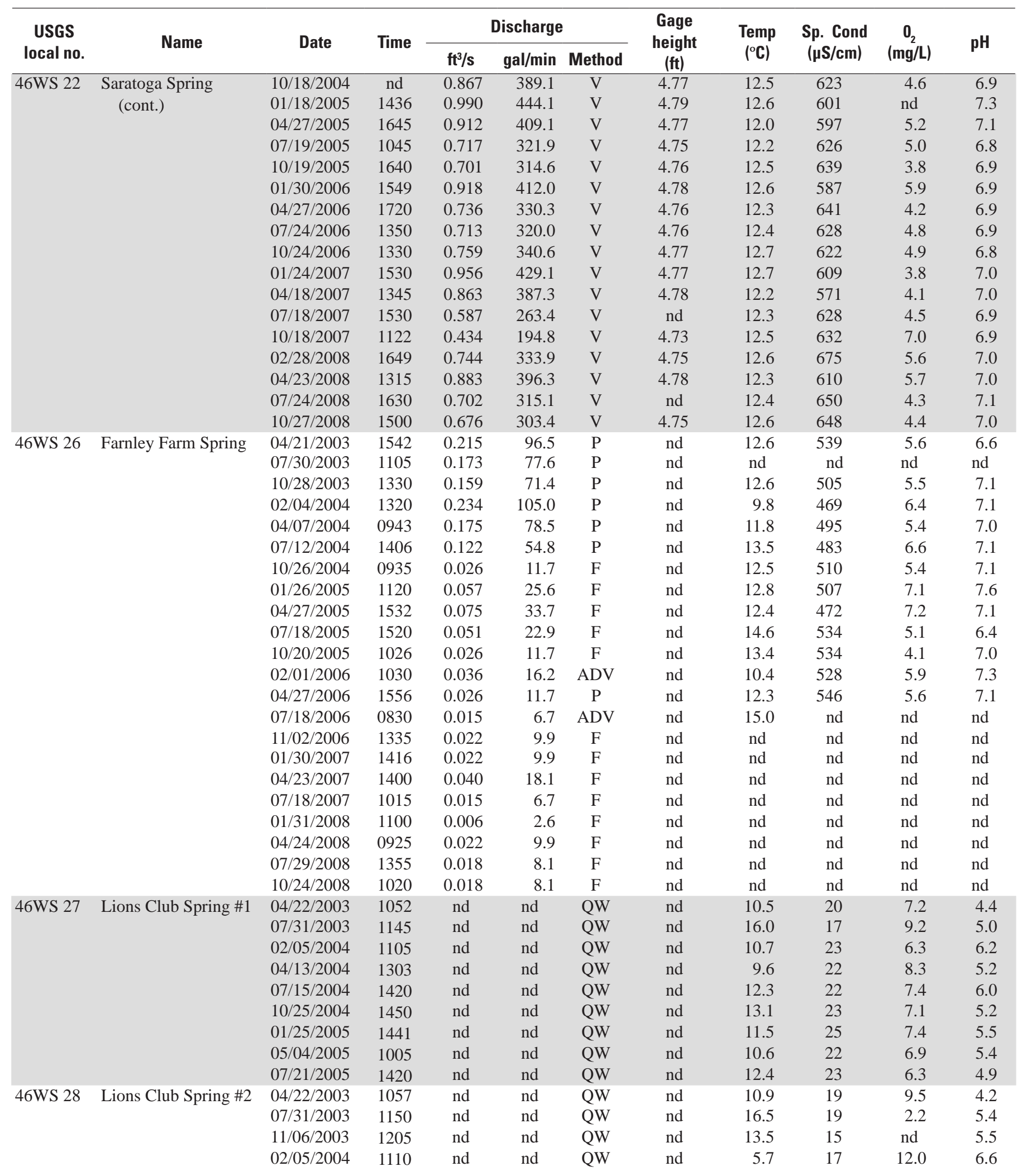


Appendix 4. Discharge and water-quality field properties from streams and springs in Clarke County, Virginia, 2003-2008.-Continued

$\left[\mathrm{ft}^{3} / \mathrm{s}\right.$, cubic feet per second; gal $/ \mathrm{min}$, gallons per minute; ft, feet; Temp., water temperature; ${ }^{\circ} \mathrm{C}$, degrees Celsius; Sp. Cond., specific conductance at $25^{\circ} \mathrm{C}$; $\mu \mathrm{S} / \mathrm{cm}$, microsiemens per centimeter; $\mathrm{O}_{2}$, dissolved oxygen; $\mathrm{mg} / \mathrm{L}$, milligrams per liter; $\mathrm{pH}$ in standard units; nd, not determined. Discharge measurement method: F, flume; ADV, acoustic doppler velocimeter; AA, standard AA velocity meter; P, pygmy velocity meter; V, volumetric. See figures 15 and 28 for location of stream and spring measurement sites]

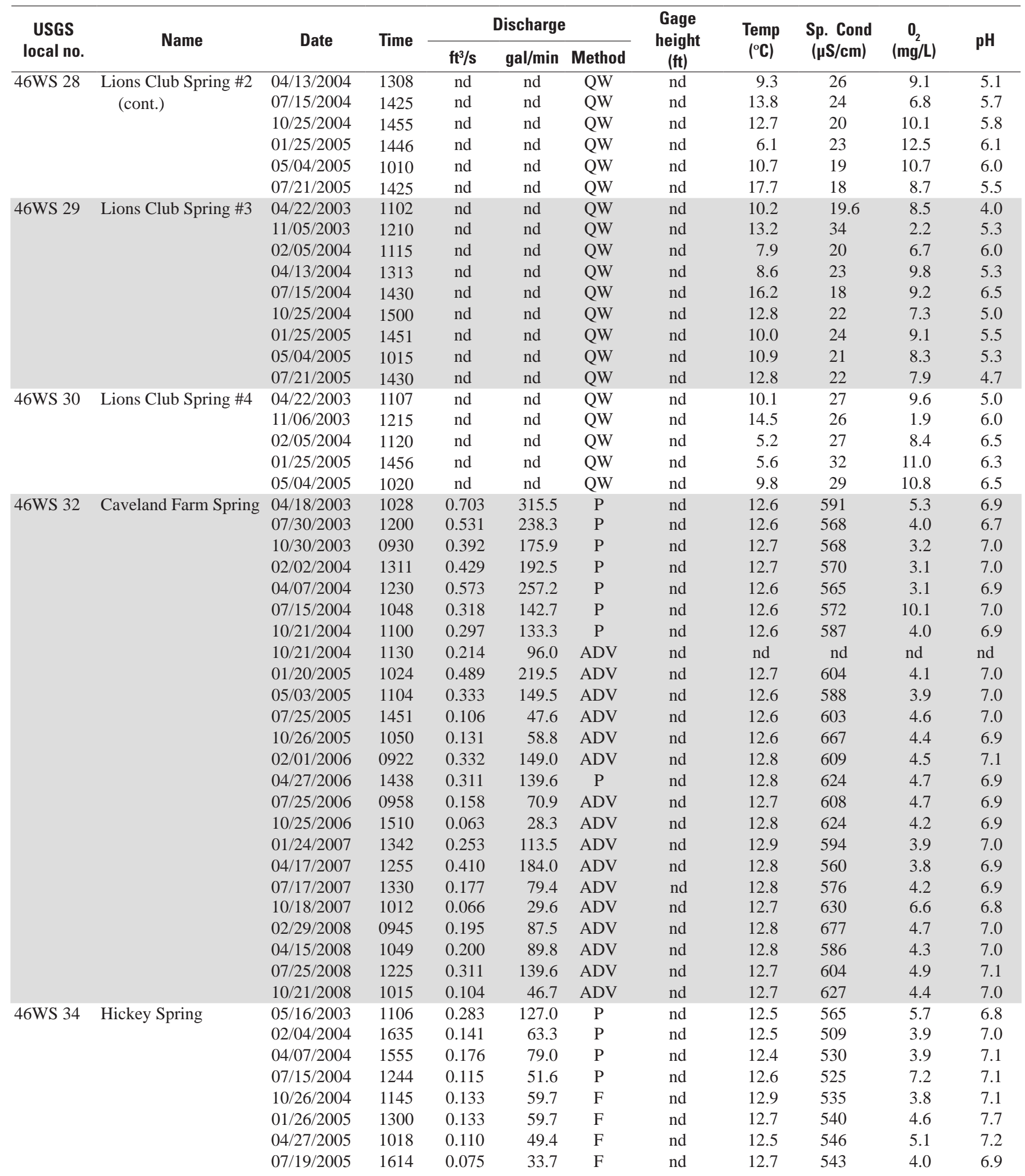


Appendix 4. Discharge and water-quality field properties from streams and springs in Clarke County, Virginia, 2003-2008.—Continued

$\left[\mathrm{ft}^{3} / \mathrm{s}\right.$, cubic feet per second; gal $/ \mathrm{min}$, gallons per minute; $\mathrm{ft}$, feet; Temp., water temperature; ${ }^{\circ} \mathrm{C}$, degrees Celsius; Sp. Cond., specific conductance at $25^{\circ} \mathrm{C}$; $\mu \mathrm{S} / \mathrm{cm}$, microsiemens per centimeter; $\mathrm{O}_{2}$, dissolved oxygen; $\mathrm{mg} / \mathrm{L}$, milligrams per liter; $\mathrm{pH}$ in standard units; nd, not determined. Discharge measurement method: F, flume; ADV, acoustic doppler velocimeter; AA, standard AA velocity meter; P, pygmy velocity meter; V, volumetric. See figures 15 and 28 for location of stream and spring measurement sites]

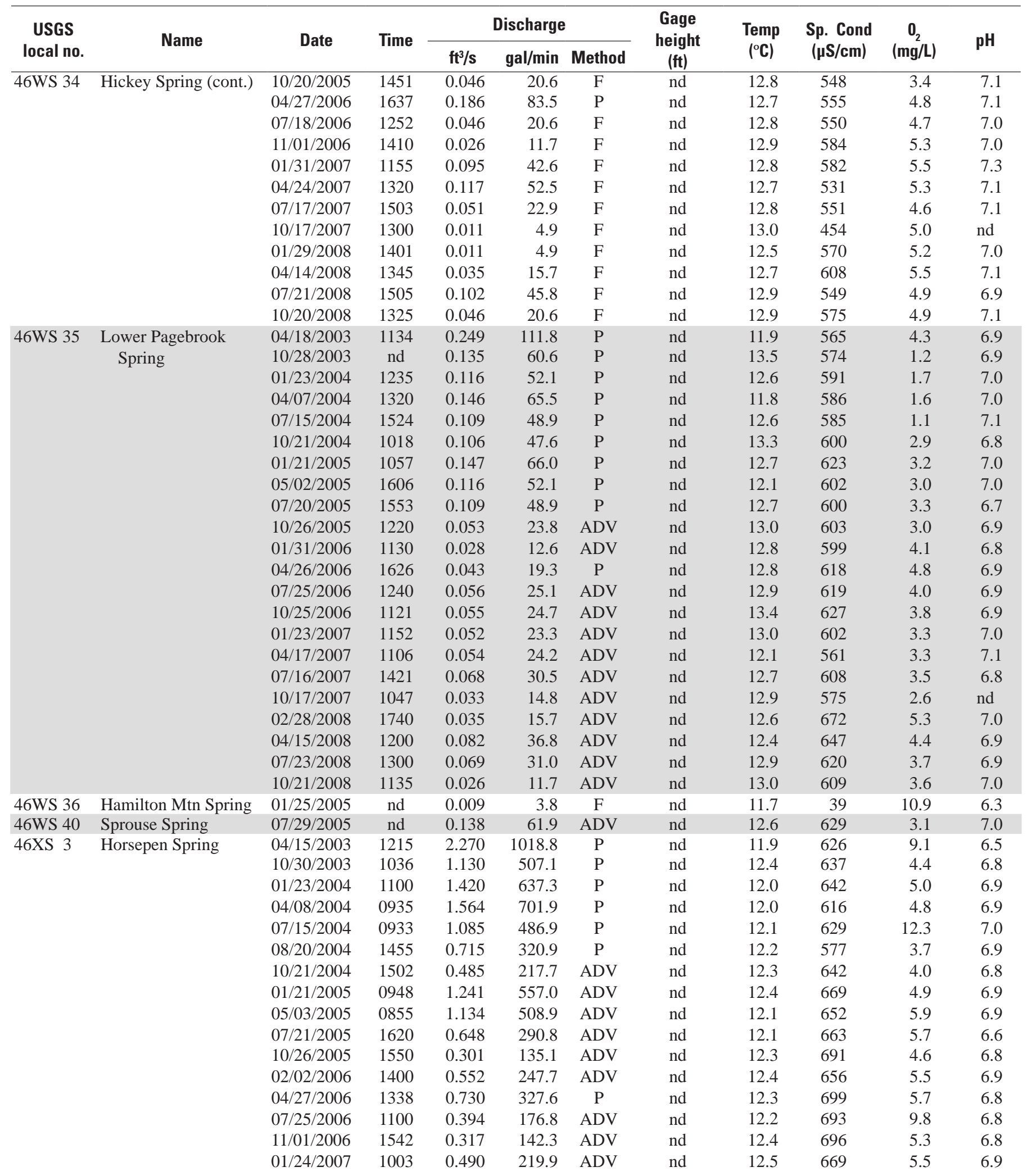


Appendix 4. Discharge and water-quality field properties from streams and springs in Clarke County, Virginia, 2003-2008.-Continued

$\left[\mathrm{ft}^{3} / \mathrm{s}\right.$, cubic feet per second; gal $/ \mathrm{min}$, gallons per minute; ft, feet; Temp., water temperature; ${ }^{\circ} \mathrm{C}$, degrees Celsius; Sp. Cond., specific conductance at $25^{\circ} \mathrm{C}$; $\mu \mathrm{S} / \mathrm{cm}$, microsiemens per centimeter; $\mathrm{O}_{2}$, dissolved oxygen; $\mathrm{mg} / \mathrm{L}$, milligrams per liter; $\mathrm{pH}$ in standard units; nd, not determined. Discharge measurement method: F, flume; ADV, acoustic doppler velocimeter; AA, standard AA velocity meter; P, pygmy velocity meter; V, volumetric. See figures 15 and 28 for location of stream and spring measurement sites]

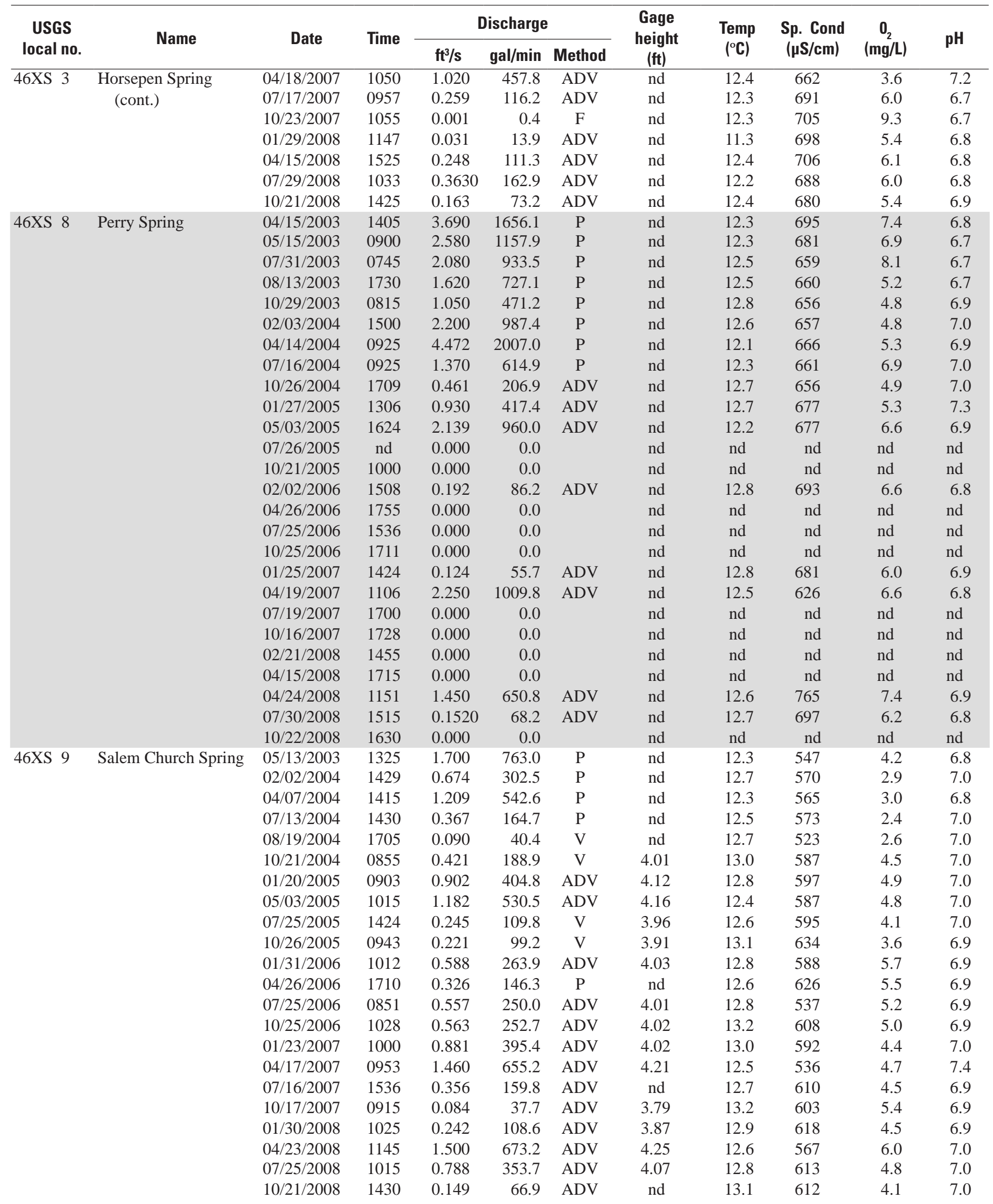


Appendix 4. Discharge and water-quality field properties from streams and springs in Clarke County, Virginia, 2003-2008.—Continued

$\left[\mathrm{ft}^{3} / \mathrm{s}\right.$, cubic feet per second; gal $/ \mathrm{min}$, gallons per minute; ft, feet; Temp., water temperature; ${ }^{\circ} \mathrm{C}$, degrees Celsius; Sp. Cond., specific conductance at $25^{\circ} \mathrm{C}$; $\mu \mathrm{S} / \mathrm{cm}$, microsiemens per centimeter; $\mathrm{O}_{2}$, dissolved oxygen; $\mathrm{mg} / \mathrm{L}$, milligrams per liter; $\mathrm{pH}$ in standard units; nd, not determined. Discharge measurement method: F, flume; ADV, acoustic doppler velocimeter; AA, standard AA velocity meter; P, pygmy velocity meter; V, volumetric. See figures 15 and 28 for location of stream and spring measurement sites]

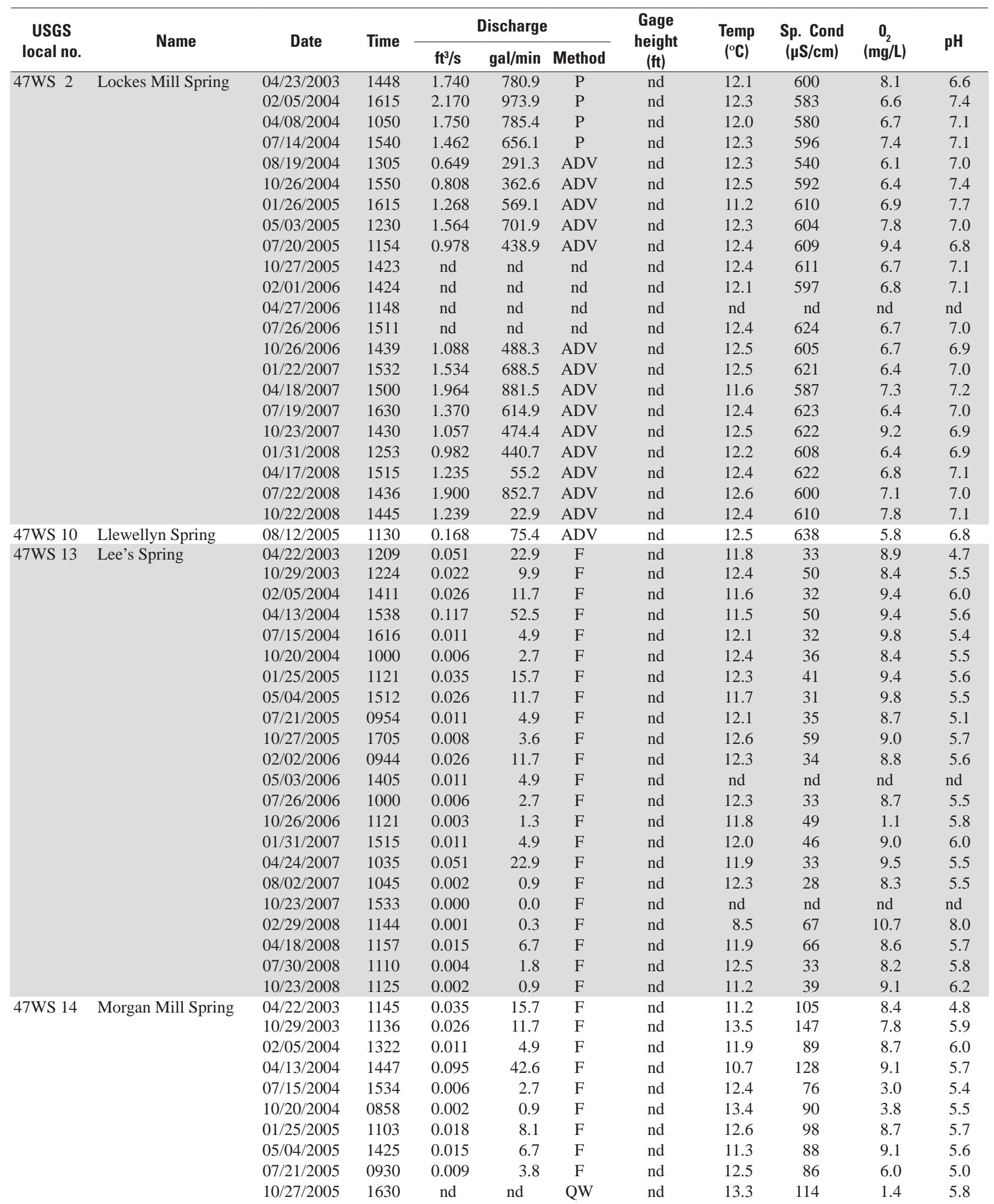


Appendix 4. Discharge and water-quality field properties from streams and springs in Clarke County, Virginia, 2003-2008.—Continued

$\left[\mathrm{ft} / \mathrm{s}\right.$, cubic feet per second; gal $/ \mathrm{min}$, gallons per minute; ft, feet; Temp., water temperature; ${ }^{\circ} \mathrm{C}$, degrees Celsius; Sp. Cond., specific conductance at $25^{\circ} \mathrm{C}$; $\mu \mathrm{S} / \mathrm{cm}$, microsiemens per centimeter; $\mathrm{O}_{2}$, dissolved oxygen; $\mathrm{mg} / \mathrm{L}$, milligrams per liter; $\mathrm{pH}$ in standard units; nd, not determined. Discharge measurement method: F, flume; ADV, acoustic doppler velocimeter; AA, standard AA velocity meter; P, pygmy velocity meter; V, volumetric. See figures 15 and 28 for location of stream and spring measurement sites]

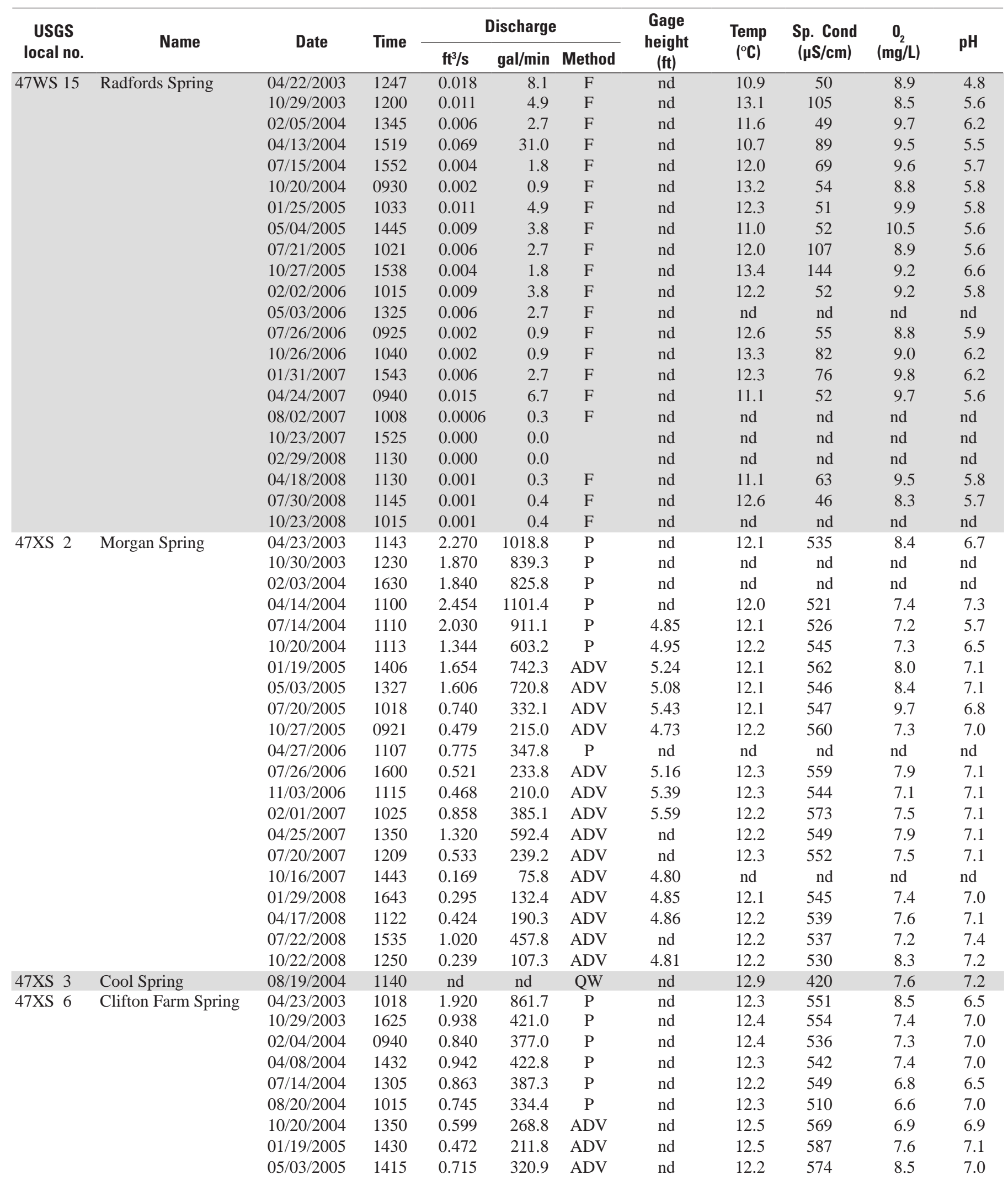


Appendix 4. Discharge and water-quality field properties from streams and springs in Clarke County, Virginia, 2003-2008._Continued

$\left[\mathrm{ft}^{3} / \mathrm{s}\right.$, cubic feet per second; gal $/ \mathrm{min}$, gallons per minute; ft, feet; Temp., water temperature; ${ }^{\circ} \mathrm{C}$, degrees Celsius; Sp. Cond., specific conductance at $25^{\circ} \mathrm{C}$; $\mu \mathrm{S} / \mathrm{cm}$, microsiemens per centimeter; $\mathrm{O}_{2}$, dissolved oxygen; $\mathrm{mg} / \mathrm{L}$, milligrams per liter; $\mathrm{pH}$ in standard units; nd, not determined. Discharge measurement method: F, flume; ADV, acoustic doppler velocimeter; AA, standard AA velocity meter; P, pygmy velocity meter; V, volumetric. See figures 15 and 28 for location of stream and spring measurement sites]

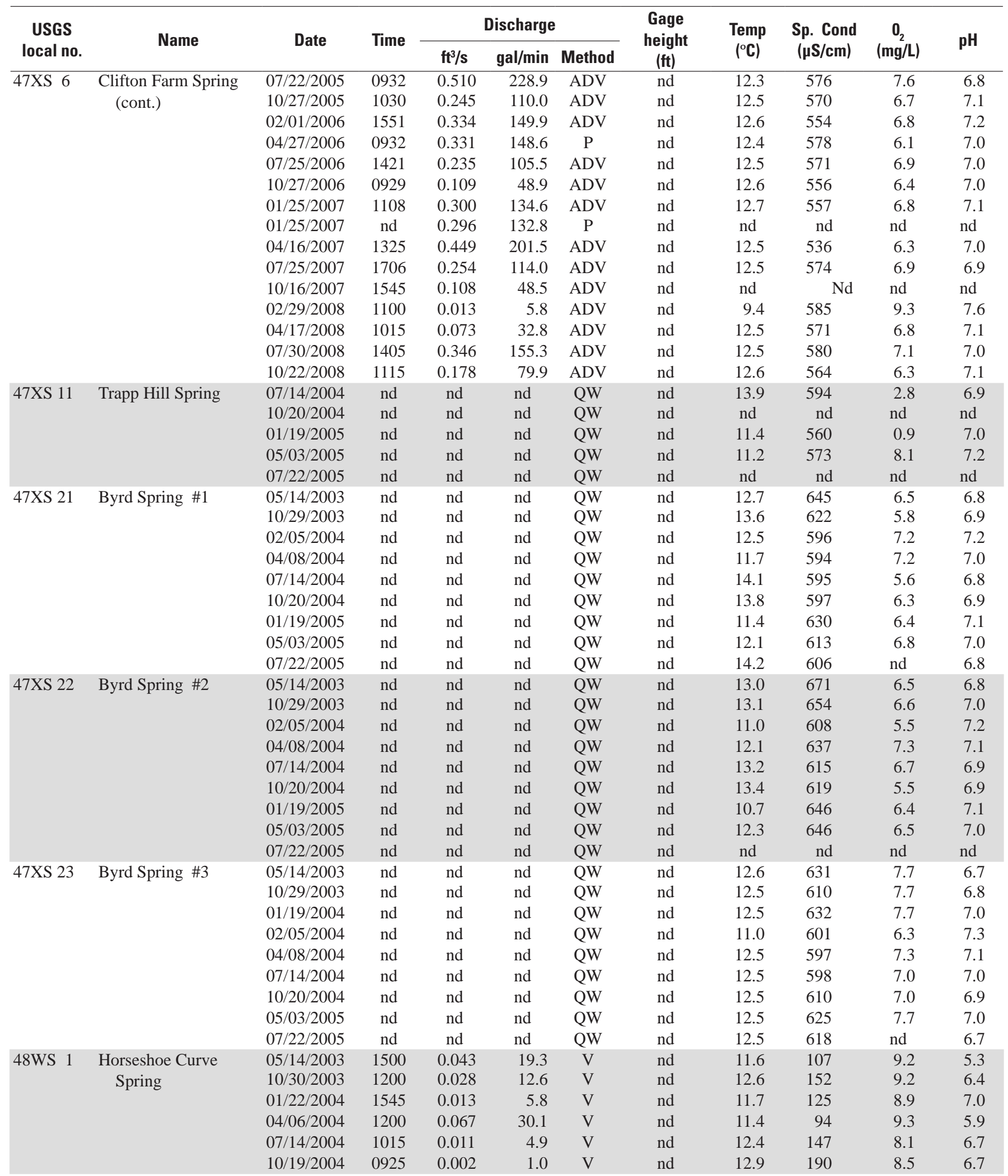


Appendix 4. Discharge and water-quality field properties from streams and springs in Clarke County, Virginia, 2003-2008.-Continued

$\left[\mathrm{ft}^{3} / \mathrm{s}\right.$, cubic feet per second; gal $/ \mathrm{min}$, gallons per minute; ft, feet; Temp., water temperature; ${ }^{\circ} \mathrm{C}$, degrees Celsius; Sp. Cond., specific conductance at $25{ }^{\circ} \mathrm{C}$; $\mu \mathrm{S} / \mathrm{cm}$, microsiemens per centimeter; $\mathrm{O}_{2}$, dissolved oxygen; $\mathrm{mg} / \mathrm{L}$, milligrams per liter; $\mathrm{pH}$ in standard units; nd, not determined. Discharge measurement method: F, flume; ADV, acoustic doppler velocimeter; AA, standard AA velocity meter; P, pygmy velocity meter; V, volumetric. See figures 15 and 28 for location of stream and spring measurement sites]

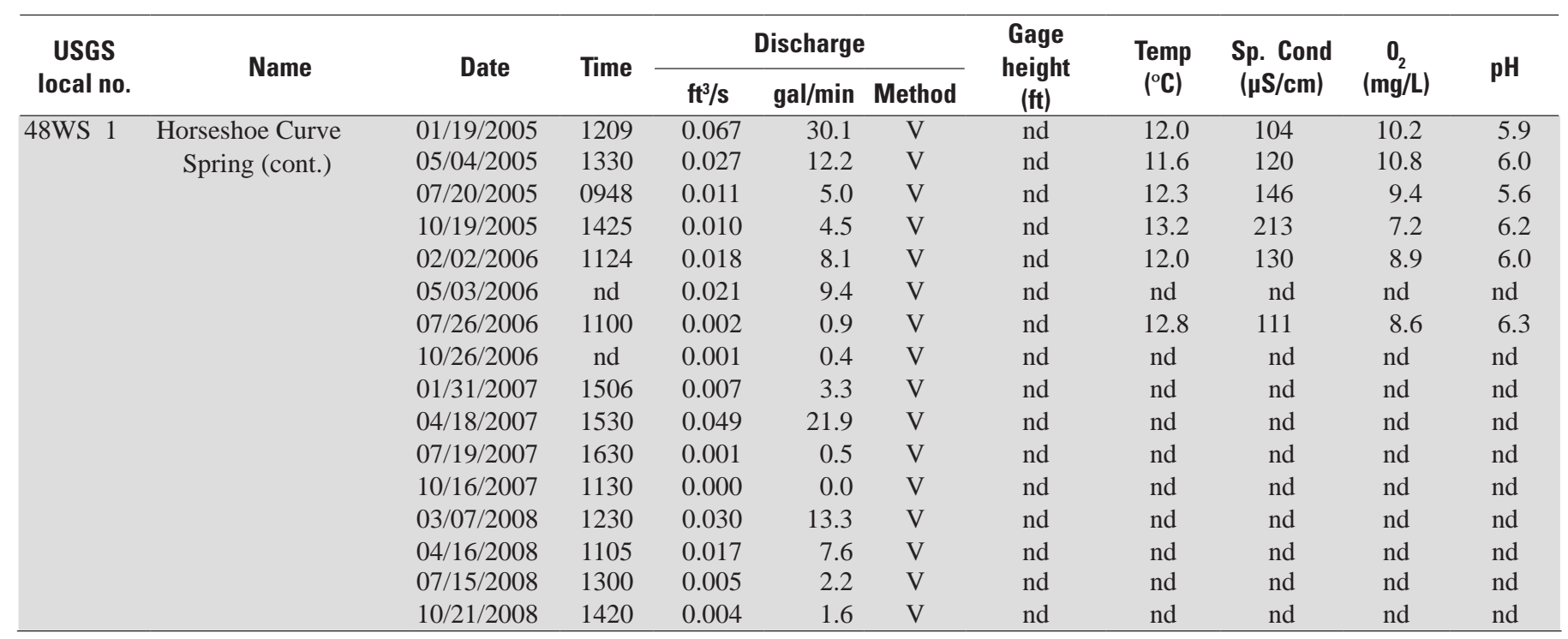




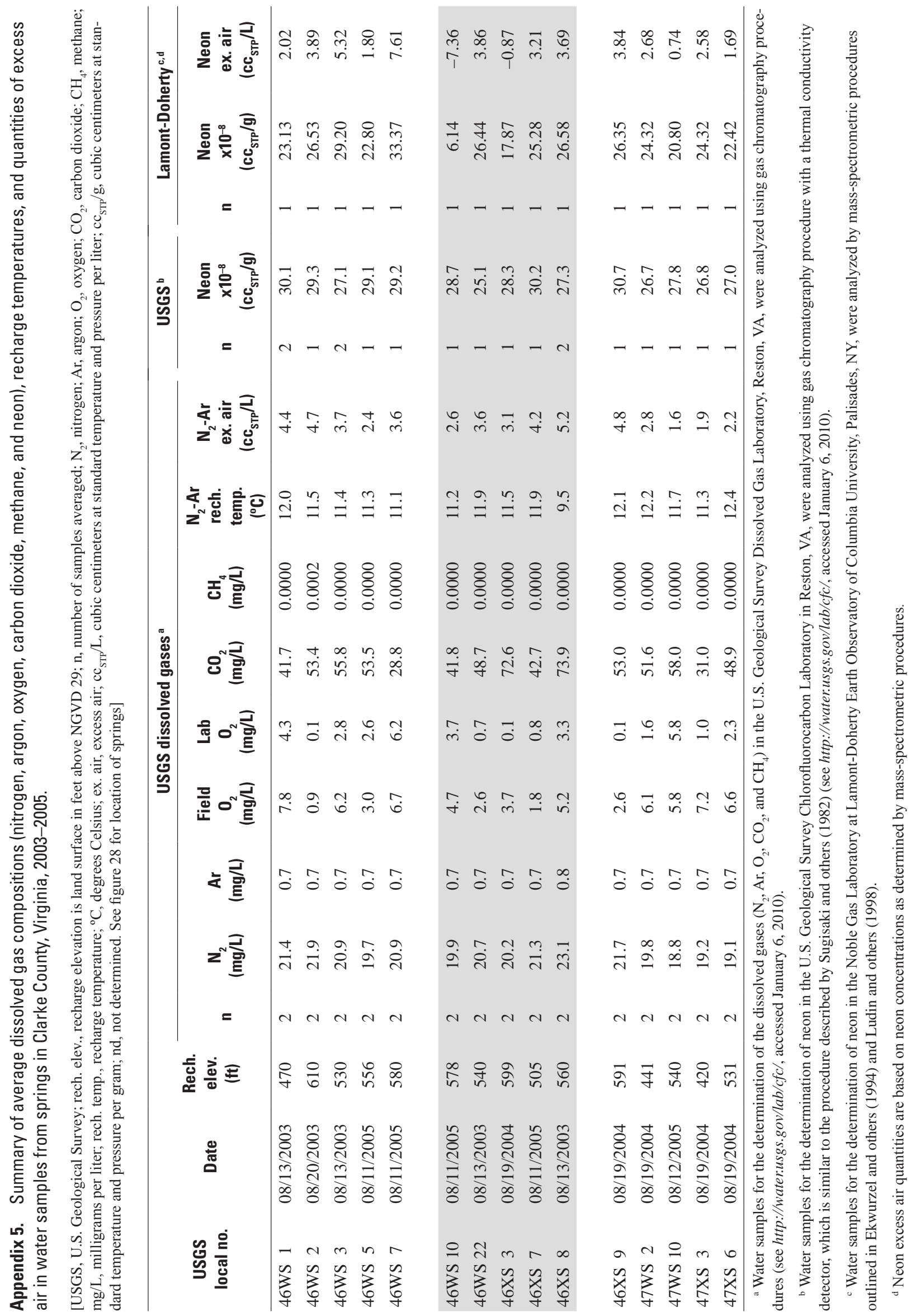


Appendix 6. Concentrations of chlorofluorocarbons and sulfur hexafluoride in North American air, 1940-2006.

[CFC-11, (trichlorofluoromethane, $\mathrm{CFCl}_{3}$ ); $\mathrm{CFC}-12$, (dichlorodifluoromethane, $\mathrm{CF}_{2} \mathrm{Cl}_{2}$ ); $\mathrm{CFC}-113$, (trichlorotrifluoroethane, $\mathrm{C}_{2} \mathrm{~F}_{3} \mathrm{Cl}_{3}$ ); $\mathrm{SF}_{6}$, sulfur hexafluoride; Mod., modern; Cont., contaminated; Concentrations in parts per trillion by volume (pptv); Data from Plummer and others (2000) and E. Busenberg

(U.S. Geological Survey, written commun., 2005)]

\begin{tabular}{|c|c|c|c|c|c|c|c|c|c|c|c|c|c|c|}
\hline Year & CFC-11 & CFC-12 & CFC-113 & $\mathrm{SF}_{6}$ & Year & CFC-11 & CFC-12 & CFC-113 & $\mathrm{SF}_{6}$ & Year & CFC-11 & CFC-12 & CFC-113 & $\mathrm{SF}_{6}$ \\
\hline 1940.0 & 0.000 & 0.000 & 0.000 & 0.000 & 1965.0 & 26.251 & 67.916 & 2.848 & 0.120 & 1990.0 & 265.758 & 493.523 & 74.512 & 2.340 \\
\hline 1940.5 & 0.000 & 0.396 & 0.000 & 0.000 & 1965.5 & 28.586 & 72.530 & 3.064 & 0.130 & 1990.5 & 266.861 & 497.131 & 76.633 & 2.440 \\
\hline 1941.0 & 0.000 & 0.478 & 0.000 & 0.000 & 1966.0 & 31.199 & 77.643 & 3.280 & 0.140 & 1991.0 & 269.216 & 503.382 & 78.755 & 2.540 \\
\hline 1941.5 & 0.000 & 0.559 & 0.000 & 0.000 & 1966.5 & 33.802 & 82.755 & 3.526 & 0.150 & 1991.5 & 270.100 & 508.779 & 80.287 & 2.650 \\
\hline 1942.0 & 0.000 & 0.661 & 0.000 & 0.000 & 1967.0 & 36.743 & 88.518 & 3.771 & 0.160 & 1992.0 & 271.521 & 517.703 & 81.514 & 2.750 \\
\hline 1942.5 & 0.000 & 0.762 & 0.000 & 0.000 & 1967.5 & 39.694 & 94.281 & 4.056 & 0.180 & 1992.5 & 272.217 & 520.468 & 82.300 & 2.860 \\
\hline 1943.0 & 0.000 & 0.884 & 0.000 & 0.000 & 1968.0 & 43.033 & 100.735 & 4.331 & 0.190 & 1993.0 & 272.346 & 522.958 & 82.693 & 2.970 \\
\hline 1943.5 & 0.000 & 1.006 & 0.000 & 0.000 & 1968.5 & 46.371 & 107.179 & 4.655 & 0.200 & 1993.5 & 272.445 & 526.007 & 82.987 & 3.090 \\
\hline 1944.0 & 0.000 & 1.179 & 0.000 & 0.000 & 1969.0 & 50.246 & 114.355 & 4.979 & 0.210 & 1994.0 & 272.793 & 528.162 & 83.184 & 3.200 \\
\hline 1944.5 & 0.000 & 1.342 & 0.000 & 0.000 & 1969.5 & 54.121 & 121.521 & 5.352 & 0.220 & 1994.5 & 272.187 & 533.305 & 83.528 & 3.320 \\
\hline 1945.0 & 0.048 & 1.555 & 0.000 & 0.000 & 1970.0 & 58.513 & 129.347 & 5.726 & 0.230 & 1995.0 & 272.033 & 534.687 & 83.557 & 3.440 \\
\hline 1945.5 & 0.055 & 1.769 & 0.000 & 0.000 & 1970.5 & 62.895 & 137.163 & 6.148 & 0.250 & 1995.5 & 271.327 & 534.789 & 83.650 & 3.570 \\
\hline 1946.0 & 0.069 & 2.155 & 0.000 & 0.000 & 1971.0 & 67.674 & 145.508 & 6.570 & 0.260 & 1996.0 & 271.024 & 535.744 & 83.550 & 3.690 \\
\hline 1946.5 & 0.081 & 2.531 & 0.000 & 0.000 & 1971.5 & 72.463 & 153.852 & 7.051 & 0.270 & 1996.5 & 269.514 & 537.406 & 83.500 & 3.820 \\
\hline 1947.0 & 0.109 & 3.110 & 0.000 & 0.000 & 1972.0 & 77.839 & 162.919 & 7.543 & 0.280 & 1997.0 & 269.037 & 539.317 & 83.400 & 3.950 \\
\hline 1947.5 & 0.139 & 3.700 & 0.000 & 0.000 & 1972.5 & 83.214 & 171.995 & 8.102 & 0.300 & 1997.5 & 268.009 & 540.882 & 83.300 & 4.080 \\
\hline 1948.0 & 0.199 & 4.371 & 0.000 & 0.000 & 1973.0 & 89.354 & 182.027 & 8.652 & 0.320 & 1998.0 & 267.263 & 542.117 & 83.150 & 4.220 \\
\hline 1948.5 & 0.248 & 5.041 & 0.000 & 0.000 & 1973.5 & 95.495 & 192.059 & 9.291 & 0.340 & 1998.5 & 266.310 & 543.728 & 83.000 & 4.320 \\
\hline 1949.0 & 0.338 & 5.763 & 0.000 & 0.000 & 1974.0 & 102.202 & 202.884 & 9.929 & 0.360 & 1999.0 & 265.619 & 544.003 & 82.800 & 4.430 \\
\hline 1949.5 & 0.427 & 6.485 & 0.000 & 0.000 & 1974.5 & 108.908 & 213.698 & 10.666 & 0.390 & 1999.5 & 264.188 & 544.587 & 82.600 & 4.540 \\
\hline 1950.0 & 0.556 & 7.277 & 0.000 & 0.000 & 1975.0 & 114.572 & 224.025 & 11.392 & 0.420 & 2000.0 & 263.841 & 545.055 & 82.300 & 4.650 \\
\hline 1950.5 & 0.676 & 8.070 & 0.000 & 0.000 & 1975.5 & 122.104 & 234.341 & 12.227 & 0.450 & 2000.5 & 263.234 & 546.269 & 82.100 & 4.770 \\
\hline 1951.0 & 0.854 & 8.934 & 0.000 & 0.000 & 1976.0 & 128.920 & 244.190 & 13.072 & 0.480 & 2001.0 & 261.843 & 546.515 & 81.700 & 4.890 \\
\hline 1951.5 & 1.023 & 9.798 & 0.000 & 0.000 & 1976.5 & 135.130 & 254.039 & 14.024 & 0.520 & 2001.5 & 260.795 & 546.102 & 81.300 & 5.010 \\
\hline 1952.0 & 1.282 & 10.693 & 0.000 & 0.000 & 1977.0 & 142.085 & 263.268 & 14.987 & 0.550 & 2002.0 & 260.120 & 545.299 & 81.000 & 5.140 \\
\hline 1952.5 & 1.530 & 11.597 & 0.000 & 0.054 & 1977.5 & 146.705 & 272.497 & 16.087 & 0.590 & 2002.5 & 258.569 & 544.724 & 80.600 & 5.270 \\
\hline 1953.0 & 1.878 & 12.593 & 0.000 & 0.054 & 1978.0 & 149.964 & 282.407 & 17.187 & 0.630 & 2003.0 & 258.137 & 543.306 & 80.250 & 5.400 \\
\hline 1953.5 & 2.216 & 13.599 & & 0.054 & 1978.5 & 156.502 & 292.855 & 18.444 & 0.680 & 2003.5 & 256.051 & 542.758 & & 5.530 \\
\hline 1954.0 & 2.643 & 14.738 & 0.530 & 0.055 & 1979.0 & 159.801 & 298.090 & 19.701 & 0.730 & 2004.0 & 255.057 & 542.148 & 79.550 & 5.670 \\
\hline 1954.5 & 3.060 & 15.876 & 0.579 & 0.055 & 1979.5 & 162.642 & 301.190 & 21.145 & 0.770 & 2004.5 & 253.467 & 541.233 & 79.100 & 5.780 \\
\hline 1955.0 & 3.577 & 17.147 & 0.629 & 0.055 & 1980.0 & 168.584 & 311.212 & 22.588 & 0.830 & 2005.0 & 252.374 & 540.318 & 78.750 & 5.890 \\
\hline 1955.5 & 4.094 & 18.417 & 0.687 & 0.056 & 1980.5 & 172.807 & 317.422 & 24.150 & 0.880 & 2005.5 & 250.983 & 539.698 & 78.400 & 6.000 \\
\hline 1956.0 & 4.739 & 19.901 & 0.746 & 0.056 & 1981.0 & 175.996 & 322.737 & 25.721 & 0.940 & 2006.0 & 249.592 & 538.692 & 78.100 & 6.110 \\
\hline 1956.5 & 5.375 & 21.385 & 0.805 & 0.057 & 1981.5 & 179.732 & 333.796 & 27.342 & 0.990 & & & & & \\
\hline 1957.0 & 6.091 & 23.062 & 0.874 & 0.058 & 1982.0 & 183.846 & 343.604 & 28.962 & 1.050 & Mod. & 284.000 & 550.000 & 87.000 & 6.200 \\
\hline 1957.5 & 6.806 & 24.749 & 0.943 & 0.059 & 1982.5 & 188.347 & 352.721 & 30.759 & 1.120 & Cont. & 294.000 & 570.000 & 92.000 & 6.300 \\
\hline 1958.0 & 7.462 & 26.498 & 1.021 & 0.060 & 1983.0 & 193.295 & 361.594 & 32.547 & 1.180 & & & & & \\
\hline 1958.5 & 8.108 & 28.256 & 1.110 & 0.061 & 1983.5 & 198.015 & 372.236 & 34.796 & 1.250 & & & & & \\
\hline 1959.0 & 8.764 & 30.218 & 1.188 & 0.062 & 1984.0 & 201.939 & 378.589 & 37.035 & 1.320 & & & & & \\
\hline 1959.5 & 9.419 & 32.179 & 1.287 & 0.064 & 1984.5 & 206.023 & 386.232 & 39.696 & 1.390 & & & & & \\
\hline 1960.0 & 10.294 & 34.517 & 1.385 & 0.066 & 1985.0 & 211.229 & 395.380 & 42.348 & 1.470 & & & & & \\
\hline 1960.5 & 11.168 & 36.855 & 1.493 & 0.069 & 1985.5 & 217.261 & 403.257 & 45.177 & 1.540 & & & & & \\
\hline 1961.0 & 12.291 & 39.477 & 1.601 & 0.072 & 1986.0 & 222.984 & 414.620 & 48.015 & 1.620 & & & & & \\
\hline 1961.5 & 13.424 & 42.089 & 1.728 & 0.076 & 1986.5 & 227.912 & 423.463 & 51.128 & 1.700 & & & & & \\
\hline 1962.0 & 14.854 & 45.098 & 1.856 & 0.079 & 1987.0 & 233.466 & 433.586 & 54.241 & 1.790 & & & & & \\
\hline 1962.5 & 16.275 & 48.096 & 1.994 & 0.084 & 1987.5 & 241.047 & 449.310 & 57.738 & 1.870 & & & & & \\
\hline 1963.0 & 18.024 & 51.613 & 2.141 & 0.088 & 1988.0 & 248.648 & 459.474 & 61.224 & 1.960 & & & & & \\
\hline 1963.5 & 19.763 & 55.130 & 2.308 & 0.095 & 1988.5 & 253.964 & 469.089 & 64.868 & 2.050 & & & & & \\
\hline 1964.0 & 21.839 & 59.226 & 2.475 & 0.100 & 1989.0 & 257.442 & 476.671 & 68.521 & 2.150 & & & & & \\
\hline 1964.5 & 23.906 & 63.312 & 2.661 & 0.110 & 1989.5 & 261.983 & 484.030 & 71.517 & 2.240 & & & & & \\
\hline
\end{tabular}


Appendix 7. Summary of average chlorofluorocarbon concentrations and calculated atmospheric partial pressures in water samples from springs in Clarke County, Virginia, 2003-2005.

[CFC-11, (trichlorofluoromethane, $\mathrm{CFC1}_{3}$ ); $\mathrm{CFC}-12$, (dichlorodifluoromethane, $\mathrm{CF}_{2} \mathrm{Cl}_{2}$ ); $\mathrm{CFC}-113$, (trichlorotrifluoroethane, $\mathrm{C}_{2} \mathrm{~F}_{3} \mathrm{Cl}_{3}$ ); pg/kg, picograms per kilogram; $\mathrm{N}_{2}$-Ar Rech. temp., nitrogen-argon recharge temperature; ${ }^{\circ} \mathrm{C}$, degrees Celsius; rech. elev., recharge elevation in feet above NGVD 29; pptv, parts per trillion by volume; nd, not determined. See figure 28 for location of springs]

\begin{tabular}{|c|c|c|c|c|c|c|c|c|c|}
\hline \multirow[t]{2}{*}{$\begin{array}{c}\text { USGS } \\
\text { local no. }\end{array}$} & \multirow[t]{2}{*}{ Date } & \multicolumn{3}{|c|}{$\begin{array}{l}\text { Average concentration } \\
\text { in water } \\
(\mathrm{pg} / \mathrm{kg})^{\mathrm{a}}\end{array}$} & \multirow{2}{*}{$\begin{array}{l}\mathrm{N}_{2}-\mathrm{Ar} \\
\text { rech. } \\
\text { temp. } \\
\left({ }^{\circ} \mathrm{C}\right)\end{array}$} & \multirow[t]{2}{*}{$\begin{array}{l}\text { Rech. } \\
\text { elev. } \\
\text { (ft) }\end{array}$} & \multicolumn{3}{|c|}{$\begin{array}{c}\text { Average calculated atmospheric } \\
\text { partial pressure } \\
\text { (pptv) }\end{array}$} \\
\hline & & CFC-11 & CFC-12 & CFC-113 & & & CFC-11 & CFC-12 & CFC-113 \\
\hline 46WS 1 & 08/13/2003 & $1,936.4$ & 314.0 & 71.9 & 12.0 & 470 & 757.5 & 516.3 & 65.9 \\
\hline 46WS 2 & 08/20/2003 & 431.9 & 297.2 & 78.2 & 11.5 & 600 & 165.5 & 479.0 & 69.9 \\
\hline 46WS 3 & 08/13/2003 & 873.5 & 359.5 & 79.7 & 11.4 & 530 & 332.6 & 580.3 & 71.2 \\
\hline 46WS 5 & 08/11/2005 & 508.1 & 334.2 & 67.9 & 11.3 & 556 & 193.2 & 543.5 & 60.9 \\
\hline 46WS 7 & 08/11/2005 & 593.0 & 307.3 & 74.4 & 11.1 & 580 & 222.6 & 490.4 & 65.4 \\
\hline 46WS 10 & 08/11/2005 & 588.1 & 324.9 & 76.8 & 11.2 & 578 & 222.5 & 525.4 & 68.5 \\
\hline 46WS 22 & 08/13/2003 & $1,235.6$ & 404.4 & 86.4 & 11.9 & 540 & 484.3 & 669.9 & 79.7 \\
\hline 46XS 3 & 08/19/2004 & $2,689.8$ & 360.2 & 82.9 & 11.5 & 599 & $1,034.0$ & 589.2 & 75.1 \\
\hline 46XS 7 & 08/11/2005 & 376.5 & 243.1 & 42.6 & 11.9 & 505 & 146.9 & 399.4 & 39.0 \\
\hline 46XS 8 & 08/13/2003 & 637.3 & 426.1 & 85.6 & 9.5 & 560 & 218.1 & 620.7 & 67.6 \\
\hline 46XS 9 & 08/19/2004 & 667.5 & 353.8 & 78.8 & 12.1 & 591 & 263.7 & 585.4 & 72.8 \\
\hline 47WS 2 & 08/19/2004 & 721.2 & 371.1 & 80.8 & 12.2 & 441 & 286.2 & 624.6 & 75.8 \\
\hline 47WS 10 & 08/12/2005 & 629.1 & 477.9 & 78.5 & 11.7 & 540 & 244.7 & 797.2 & 72.5 \\
\hline 47XS 3 & 08/19/2004 & 509.8 & 262.6 & 65.4 & 11.3 & 441 & 193.3 & 427.4 & 58.7 \\
\hline 47XS 6 & 08/19/2004 & 803.8 & 367.0 & 80.2 & 12.4 & 531 & 324.0 & 629.1 & 76.7 \\
\hline
\end{tabular}

a Water samples for the determination of chlorofluorocarbons in the U.S. Geological Survey Chlorofluorocarbon Laboratory, Reston, VA, were analyzed using purge and trap gas chromatography with an electron-capture detector (Busenberg and Plummer, 1992; see http://water.usgs.gov/lab/cfc/, accessed January 6, 2010). 
Appendix 8. Summary of average chlorofluorocarbon-based model piston-flow apparent recharge dates, ages, and uncertainties in water samples from springs in Clarke County, Virginia, 2003-2005.

[CFC-11, (trichlorofluoromethane, $\mathrm{CFC1}_{3}$ ); $\mathrm{CFC}-12$, (dichlorodifluoromethane, $\mathrm{CF}_{2} \mathrm{Cl}_{2}$ ); $\mathrm{CFC}-113$, (trichlorotrifluoroethane, $\mathrm{C}_{2} \mathrm{~F}_{3} \mathrm{Cl}_{3}$ ); $\mathrm{C}$, contaminated (sample concentration higher than that of water in equilibrium with modern North American air); NP, not possible; Mod, modern; Apparent age uncertainties are based on changes in age resulting from uncertainty in nitrogen-argon $\left(\mathrm{N}_{2}-\mathrm{Ar}\right)$ recharge temperature of \pm 1 degree Celsius. Dates and ages are based on the North American air data in appendix 6 . Numbers in parentheses indicate possible recharge years before and after atmospheric peak concentration. See figure 28 for location of springs]

\begin{tabular}{|c|c|c|c|c|c|c|c|c|c|c|c|c|c|}
\hline \multirow{2}{*}{$\begin{array}{l}\text { USGS } \\
\text { local no. }\end{array}$} & \multirow[t]{2}{*}{ Date } & \multicolumn{6}{|c|}{$\begin{array}{l}\text { Model piston-flow } \\
\text { average apparent recharge date }\end{array}$} & \multicolumn{6}{|c|}{$\begin{array}{l}\text { Model piston-flow } \\
\text { average apparent age and uncertainity } \\
\text { (years) }\end{array}$} \\
\hline & & $\begin{array}{l}\text { CFC-11 } \\
\text { (1) }\end{array}$ & $\begin{array}{c}\text { CFC-11 } \\
\text { (2) }\end{array}$ & $\begin{array}{c}\text { CFC-12 } \\
\text { (1) }\end{array}$ & $\begin{array}{l}\text { CFC-12 } \\
(2)\end{array}$ & $\begin{array}{l}\text { CFC-113 } \\
\text { (1) }\end{array}$ & $\begin{array}{l}\text { CFC-113 } \\
\text { (2) }\end{array}$ & $\begin{array}{l}\text { CFC-11 } \\
\text { (1) }\end{array}$ & $\begin{array}{l}\text { CFC-11 } \\
(2)\end{array}$ & $\begin{array}{l}\text { CFC-12 } \\
\text { (1) }\end{array}$ & $\begin{array}{l}\text { CFC-12 } \\
(2)\end{array}$ & $\begin{array}{l}\text { CFC-113 } \\
\text { (1) }\end{array}$ & $\begin{array}{l}\text { CFC-113 } \\
\text { (2) }\end{array}$ \\
\hline 46WS 1 & 08/13/2003 & $\mathrm{C}$ & $\mathrm{C}$ & 1991.5 & NP & 1988.5 & NP & $\mathrm{C}$ & $\mathrm{C}$ & $12.1 \pm 3.9$ & NP & $15.1 \pm 0.5$ & NP \\
\hline 46WS 2 & 08/20/2003 & 1979.5 & NP & 1989.0 & NP & 1989.0 & NP & $24.1 \pm 1.0$ & NP & $14.6 \pm 1.5$ & NP & $14.6 \pm 0.5$ & NP \\
\hline 46WS 3 & 08/13/2003 & $\mathrm{C}$ & $\mathrm{C}$ & $\mathrm{C}$ & $\mathrm{C}$ & 1989.0 & NP & $\mathrm{C}$ & $\mathrm{C}$ & $\mathrm{C}$ & $\mathrm{C}$ & $14.6 \pm 0.8$ & NP \\
\hline 46WS 5 & 08/11/2005 & 1982.5 & NP & 1996.5 & 2006.0 & 1987.5 & NP & $23.1 \pm 1.3$ & NP & $9.1 \pm 4.2$ & NP & $18.1 \pm 0.5$ & NP \\
\hline 46WS 7 & 08/11/2005 & 1985.5 & NP & 1989.5 & NP & 1988.5 & NP & $20.1 \pm 1.3$ & NP & $16.1 \pm 1.8$ & NP & $17.1 \pm 0.5$ & NP \\
\hline 46WS 10 & 08/11/2005 & 1985.5 & NP & 1993.0 & NP & 1988.5 & NP & $20.1 \pm 1.3$ & NP & $12.6 \pm 1.8$ & NP & $17.1 \pm 0.8$ & NP \\
\hline 46WS 22 & 08/13/2003 & $\mathrm{C}$ & $\mathrm{C}$ & $\mathrm{C}$ & $\mathrm{C}$ & 1991.0 & 2004.0 & $\mathrm{C}$ & $\mathrm{C}$ & $\mathrm{C}$ & $\mathrm{C}$ & $12.6 \pm 2.9$ & NP \\
\hline 46XS 3 & 08/19/2004 & $\mathrm{C}$ & $\mathrm{C}$ & $\mathrm{C}$ & $\mathrm{C}$ & 1990.0 & NP & $\mathrm{C}$ & $\mathrm{C}$ & $\mathrm{C}$ & $\mathrm{C}$ & $14.6 \pm 1.0$ & NP \\
\hline 46XS 7 & 08/11/2005 & 1977.5 & NP & 1985.0 & NP & 1984.0 & NP & $28.1 \pm 0.8$ & NP & $20.6 \pm 1.0$ & NP & $21.6 \pm 0.5$ & NP \\
\hline 46XS 8 & 08/13/2003 & 1985.5 & NP & $\mathrm{C}$ & $\mathrm{C}$ & 1988.5 & NP & $18.1 \pm 1.0$ & NP & $\mathrm{C}$ & $\mathrm{C}$ & $15.1 \pm 0.8$ & NP \\
\hline 46XS 9 & 08/19/2004 & 1989.5 & 2000.5 & $\mathrm{C}$ & $\mathrm{C}$ & 1989.5 & NP & $15.1 \pm 3.4$ & $4.1 \pm 6.0$ & $\mathrm{C}$ & $\mathrm{C}$ & $15.1 \pm 0.8$ & NP \\
\hline 47WS 2 & 08/19/2004 & Mod. & Mod. & $\mathrm{C}$ & $\mathrm{C}$ & 1990.0 & NP & Mod. & $\mathrm{C}$ & $\mathrm{C}$ & $\mathrm{C}$ & $14.6 \pm 0.8$ & NP \\
\hline 47WS 10 & 08/12/2005 & 1987.5 & NP & $\mathrm{C}$ & $\mathrm{C}$ & 1989.5 & NP & $18.1 \pm 1.3$ & NP & $\mathrm{C}$ & $\mathrm{C}$ & $16.1 \pm 1.0$ & NP \\
\hline 47XS 3 & 08/19/2004 & 1983.0 & NP & 1986.5 & NP & 1987.5 & NP & $21.6 \pm 1.3$ & NP & $18.1 \pm 0.8$ & NP & $17.1 \pm 0.5$ & NP \\
\hline 47XS 6 & 08/19/2004 & $\mathrm{C}$ & $\mathrm{C}$ & $\mathrm{C}$ & $\mathrm{C}$ & 1990.5 & NP & $\mathrm{C}$ & $\mathrm{C}$ & $\mathrm{C}$ & $\mathrm{C}$ & $14.1 \pm 1.0$ & NP \\
\hline
\end{tabular}

${ }^{a}$ Apparent chlorofluorocarbon recharge dates and ages were calculated using the chlorofluorocarbon program, version 3.0, revised February 2004 (Microsoft ${ }^{\circledast}$ Excel) by E. Busenberg and L.N. Plummer of the U.S. Geological Survey. 
Appendix 9. Summary of average chlorofluorocarbon-based model ratio apparent recharge dates, ages, and uncertainties in water samples from springs in Clarke County, Virginia, 2003-2005.

[CFC-11, (trichlorofluoromethane, $\mathrm{CFC1}_{3}$ ); $\mathrm{CFC}-12$, (dichlorodifluoromethane, $\mathrm{CF}_{2} \mathrm{Cl}_{2}$ ); $\mathrm{CFC}-113$, (trichlorotrifluoroethane, $\mathrm{C}_{2} \mathrm{~F}_{3} \mathrm{Cl}_{3}$ ); ${ }^{\circ} \mathrm{C}$, degrees Celsius; $\mathrm{C}$, contaminated, sample concentration higher than that of water in equilibrium with modern North American air; Apparent age uncertainties are based on changes in age resulting from uncertainty in nitrogen-argon $\left(\mathrm{N}_{2}-\mathrm{Ar}\right)$ recharge temperature of $\pm 1{ }^{\circ} \mathrm{C}$. Dates and ages are based on the North American air data in appendix 6. See figure 28 for location of springs]

\begin{tabular}{|c|c|c|c|c|c|c|c|}
\hline \multirow{2}{*}{$\begin{array}{c}\text { USGS } \\
\text { local no. }\end{array}$} & \multirow{2}{*}{ Date } & \multicolumn{3}{|c|}{$\begin{array}{c}\text { Model ratio } \\
\text { average apparent age }{ }^{\mathrm{a}}\end{array}$} & \multicolumn{3}{|c|}{ Percentage of young fraction } \\
\hline & & $\begin{array}{l}\text { CFC-11/ } \\
\text { CFC-12 }\end{array}$ & $\begin{array}{c}\text { CFC-113/ } \\
\text { CFC-12 }\end{array}$ & $\begin{array}{c}\text { CFC-113/ } \\
\text { CFC-11 }\end{array}$ & $\begin{array}{l}\text { CFC-11/ } \\
\text { CFC-12 }\end{array}$ & $\begin{array}{c}\text { CFC-113/ } \\
\text { CFC-12 }\end{array}$ & $\begin{array}{c}\text { CFC-113/ } \\
\text { CFC-11 }\end{array}$ \\
\hline 46WS 1 & 08/13/2003 & NP & NP & NP & NP & NP & NP \\
\hline 46WS 2 & 08/20/2003 & NP & NP & NP & NP & NP & NP \\
\hline 46WS 3 & 08/13/2003 & NP & NP & NP & NP & NP & NP \\
\hline 46WS 5 & 08/11/2005 & NP & NP & 10.1 & NP & NP & 72.8 \\
\hline 46WS 7 & 08/11/2005 & NP & NP & 14.6 & NP & NP & 83.1 \\
\hline 46WS 10 & 08/11/2005 & NP & NP & $10.6 \pm 0.8$ & NP & NP & 82.0 \\
\hline 46WS 22 & 08/13/2003 & NP & NP & NP & NP & NP & NP \\
\hline 46XS 3 & 08/19/2004 & NP & NP & NP & NP & NP & NP \\
\hline 46XS 7 & 08/11/2005 & NP & NP & $17.1 \pm 0.3$ & NP & NP & 60.1 \\
\hline 46XS 8 & 08/13/2003 & NP & NP & 8.1 & NP & NP & 80.9 \\
\hline 46XS 9 & 08/19/2004 & NP & NP & NP & NP & NP & NP \\
\hline 47WS 2 & 08/19/2004 & NP & NP & NP & NP & NP & NP \\
\hline 47WS 10 & 08/12/2005 & NP & NP & $14.6 \pm 0.3$ & NP & NP & 92.1 \\
\hline 47XS 3 & 08/19/2004 & NP & $16.6 \pm 0.3$ & $11.6 \pm 0.8$ & NP & 95.9 & 71.0 \\
\hline 47XS 6 & 08/19/2004 & NP & NP & NP & NP & NP & NP \\
\hline
\end{tabular}

${ }^{a}$ Apparent chlorofluorocarbon recharge dates and ages were calculated using the chlorofluorocarbon program, version 3.0, revised February 2004 (Microsoft ${ }^{\circledR}$ Excel) by E. Busenberg and L.N. Plummer of the U.S. Geological Survey. 
Appendix 10. Summary of average sulfur hexafluoride data in water samples from springs in Clarke County, Virginia, 2003-2005.

[n, number of samples averaged; $\mathrm{SF}_{6}$, sulfur hexafluoride; fmol/L, femtomoles per liter; ${ }^{\circ} \mathrm{C}$, degrees Celsius; pptv, parts per trillion by volume; cc/L, cubic centimeters per liter; ex air, excess air; $\mathrm{C}$, contaminated (sample $\mathrm{SF}_{6}$ concentration greater than that of water in equilibrium with modern air); Meas. st. dev., standard deviation of measured values; Rtemp, recharge temperature; nd, not determined; Apparent age uncertainties are based on standard deviation of measured ages, changes in recharge temperature $\left( \pm 1^{\circ} \mathrm{C}\right)$ and excess air $( \pm 1 \mathrm{cc} / \mathrm{L})$. Apparent recharge dates and ages are based on the North American air data in appendix 6 . See figure 28 for location of springs]

\begin{tabular}{|c|c|c|c|c|c|c|c|c|c|c|c|c|}
\hline \multirow[b]{2}{*}{$\begin{array}{c}\text { USGS } \\
\text { local no. }\end{array}$} & \multirow[b]{2}{*}{ Date } & \multirow[b]{2}{*}{ n } & \multirow{2}{*}{$\begin{array}{c}\mathrm{SF}_{6} \\
\text { concentration } \\
\text { in water } \\
(\mathrm{fmol} / \mathrm{L})^{\mathrm{a}}\end{array}$} & \multirow[b]{2}{*}{$\begin{array}{c}\text { Recharge } \\
\text { temperature } \\
\left({ }^{\circ} \mathrm{C}\right)\end{array}$} & \multirow{2}{*}{$\begin{array}{c}\mathrm{SF}_{6} \\
\text { partial } \\
\text { pressure } \\
\text { (pptv) }\end{array}$} & \multirow[b]{2}{*}{$\begin{array}{l}\text { Excess } \\
\text { air } \\
\text { (cc/L) }\end{array}$} & \multirow{2}{*}{$\begin{array}{c}\text { Model SF }_{6} \\
\text { partial } \\
\text { pressure } \\
\text { remove } \\
\text { ex air } \\
\text { (pptv) }\end{array}$} & \multirow{2}{*}{$\begin{array}{c}\text { Model } \mathrm{SF}_{6} \\
\text { apparent } \\
\text { recharge } \\
\text { date } \\
\text { (years) }\end{array}$} & \multirow{2}{*}{$\begin{array}{c}\text { Model } \\
\text { SF }_{6} \\
\text { apparent } \\
\text { age } \\
\text { (years) }^{b}\end{array}$} & \multicolumn{3}{|c|}{$\begin{array}{c}\text { Model } \mathrm{SF}_{6} \text { apparent age } \\
\text { uncertainity }\end{array}$} \\
\hline & & & & & & & & & & $\begin{array}{l}\text { Meas. } \\
\text { st. dev. } \\
\text { (years) }\end{array}$ & $\begin{array}{l}\text { Rtemp } \\
\pm 1^{\circ} \mathrm{C} \\
\text { (years) }\end{array}$ & $\begin{array}{c}\text { Excess air } \\
\pm 1 \mathrm{cc} / \mathrm{L} \\
\text { (years) }\end{array}$ \\
\hline 46WS 1 & 08/13/2003 & 2 & 5.685 & 12.0 & 17.48 & 4.4 & 11.27 & $\mathrm{C}$ & $\mathrm{C}$ & nd & nd & nd \\
\hline 46WS 2 & 08/20/2003 & 2 & 2.708 & 11.5 & 8.21 & 4.7 & 5.18 & 2002.0 & 1.6 & 1.1 & 0.7 & 2.1 \\
\hline 46WS 3 & 08/13/2003 & 2 & 2.869 & 11.4 & 8.64 & 3.7 & 5.95 & 2004.5 & -0.9 & nd & nd & nd \\
\hline 46WS 5 & 08/11/2005 & 2 & 2.204 & 11.3 & 4.09 & 2.4 & 2.12 & 1988.5 & 17.1 & 2.8 & 0.4 & 0.7 \\
\hline 46WS 7 & 08/11/2005 & 2 & 6.627 & 11.1 & 13.03 & 3.6 & 6.59 & $\mathrm{C}$ & $\mathrm{C}$ & nd & nd & nd \\
\hline 46WS 10 & 08/11/2005 & 2 & 5.291 & 11.2 & 9.93 & 2.6 & 5.11 & 2001.5 & 4.1 & 0.4 & 0.7 & 1.1 \\
\hline 46WS 22 & 08/13/2003 & 2 & 2.679 & 11.9 & 8.24 & 3.6 & 5.67 & 2004.0 & -0.4 & 0.4 & 1.1 & nd \\
\hline 46XS 3 & 08/19/2004 & 2 & 2.685 & 11.5 & 8.14 & 3.1 & 5.88 & 2004.5 & 0.1 & nd & nd & nd \\
\hline 46XS 7 & 08/11/2005 & 2 & 2.232 & 11.9 & 4.50 & 4.2 & 2.17 & 1989.0 & 16.6 & 1.8 & 0.4 & 0.7 \\
\hline 46XS 8 & 08/13/2003 & 2 & 2.431 & 9.5 & 6.77 & 5.2 & 4.25 & 1998.0 & 5.6 & 0.0 & 0.7 & 1.8 \\
\hline 46XS 9 & 08/19/2004 & 2 & 2.080 & 12.0 & 6.43 & 4.8 & 4.00 & 1997.0 & 7.6 & 3.5 & 0.7 & 1.8 \\
\hline 47WS 2 & 08/19/2004 & 2 & 8.346 & 12.2 & 25.87 & 2.8 & 19.10 & $\mathrm{C}$ & $\mathrm{C}$ & nd & nd & nd \\
\hline 47WS 10 & 08/12/2005 & 2 & 3.895 & 11.7 & 6.95 & 1.6 & 3.60 & 1995.5 & 10.1 & 0.7 & 0.4 & 0.7 \\
\hline 47XS 3 & 08/19/2004 & 2 & 1.961 & 11.3 & 5.86 & 1.9 & 4.76 & 2000.0 & 4.6 & 0.4 & 1.1 & 2.8 \\
\hline 47XS 6 & 08/19/2004 & 2 & 2.131 & 12.3 & 6.65 & 2.2 & 5.20 & 2002.0 & 2.6 & 0.7 & 0.7 & 2.8 \\
\hline
\end{tabular}

\footnotetext{
${ }^{a}$ Water samples for the determination of $\mathrm{SF}_{6}$ in the U.S. Geological Survey Chlorofluorocarbon Laboratory, Reston, VA, were analyzed using purge and trap gas chromatographic procedures (Busenberg and Plummer, 2000).

${ }^{b}$ Apparent $\mathrm{SF}_{6}$ recharge dates and ages were calculated using the $\mathrm{SF}_{6}$ program revised February 2003 (Microsoft ${ }^{\circledR}$ Excel) by E. Busenberg of the U.S. Geological Survey.
} 
Appendix 11. Summary of tritium, dissolved helium, and dissolved neon data in water samples from springs in Clarke County, Virginia, 2003-2005.

$\left[{ }^{3} \mathrm{H}\right.$, tritium; TU, tritium unit $\left(1 \mathrm{TU}=1\right.$ atom of ${ }^{3} \mathrm{H}$ in $10^{18}$ atoms of hydrogen $(\mathrm{H}) ; 2 \sigma, 2$ standard deviations; USGS, U.S. Geological Survey Low-Level ${ }^{3} \mathrm{H}$ Laboratory in Menlo Park, CA; LDEO, Noble Gas Laboratory at Lamont-Doherty Earth Observatory of Columbia University, Palisades, NY; cc $/ \mathrm{sT}$, cubic centimeters at standard temperature and pressure per gram; He, helium; $\mathrm{Ne}$, neon; $\Delta^{4} \mathrm{He}(\%)$, percentage of helium-4 $\left({ }^{4} \mathrm{He}\right)$ greater than solubility equilibrium concentration; $\delta^{3} \mathrm{He}=\left[\left(\mathrm{R}_{\text {sample }} / \mathrm{R}_{\text {air }}\right)-1\right] \times 100 ; \mathrm{R}$ is the ratio ${ }^{3} \mathrm{He} /{ }^{4} \mathrm{He} ; \mathrm{R}_{\text {air }}=1.384 \times 10^{-6} ; \Delta \mathrm{Ne}(\%)$, percentage of $\mathrm{Ne}$ greater than solubility equilibrium concentration; terr., terrigenic; nd, not determined. See figure 28 for location of springs]

\begin{tabular}{|c|c|c|c|c|c|c|c|c|c|c|c|}
\hline \multirow{2}{*}{$\begin{array}{c}\text { USGS } \\
\text { local no. }\end{array}$} & \multirow{2}{*}{ Date } & \multirow{2}{*}{$\begin{array}{c}{ }^{3} \mathrm{H} \\
\text { (TU) }\end{array}$} & \multirow{2}{*}{$\begin{array}{c}{ }^{3} \mathrm{H} \\
\text { error } \\
2 \sigma \\
\text { (TU) }\end{array}$} & \multirow{2}{*}{$\begin{array}{c}{ }^{3} \mathbf{H} \\
\mathbf{l a b}^{\mathbf{a}}\end{array}$} & \multicolumn{2}{|c|}{$\begin{array}{c}{ }^{4} \mathrm{He} \times 10^{-8} \\
\left(\mathrm{cc}_{\mathrm{STP}} / \mathrm{g}\right)\end{array}$} & \multirow{2}{*}{$\begin{array}{l}\Delta^{4} \mathrm{He} \\
(\%)^{\mathrm{c}}\end{array}$} & \multirow{2}{*}{$\begin{array}{l}\delta^{3} \mathrm{He} \\
(\%)^{\mathrm{c}}\end{array}$} & \multirow{2}{*}{$\begin{array}{c}\mathrm{Ne} \\
\times 10^{-8} \\
\left(\mathrm{Cc}_{\mathrm{STP}} / \mathrm{g}\right)^{\mathrm{c}}\end{array}$} & \multirow{2}{*}{$\begin{array}{l}\Delta \mathrm{Ne} \\
(\%)^{\mathrm{c}}\end{array}$} & \multirow{2}{*}{$\begin{array}{c}\text { Terr. } \\
\text { He } \\
(\%)\end{array}$} \\
\hline & & & & & USGS $^{b}$ & LDEO $^{c}$ & & & & & \\
\hline 46WS 1 & 08/13/2003 & 7.5 & 0.5 & USGS & 8.350 & 5.893 & 30.17 & 4.32 & 23.132 & 18.87 & 5.2 \\
\hline 46WS 2 & 08/20/2003 & 8.1 & 0.5 & USGS & 7.400 & 6.410 & 42.03 & 0.39 & 26.532 & 36.41 & nd \\
\hline 46WS 7 & 08/11/2005 & 7.0 & 0.6 & USGS & 7.234 & 8.666 & 91.51 & 8.91 & 33.366 & 70.78 & nd \\
\hline 46WS 10 & 08/11/2005 & 6.8 & 0.5 & USGS & 7.517 & 1.710 & -62.20 & 2.18 & 6.141 & -68.54 & 60.8 \\
\hline 46WS 22 & 08/13/2003 & 7.2 & 0.4 & USGS & 8.200 & 6.853 & 51.70 & -2.15 & 26.443 & 36.11 & 4.6 \\
\hline $46 X S 3$ & 08/19/2004 & 6.9 & 0.4 & USGS & 7.310 & 4.390 & -2.77 & 1.46 & 17.869 & -8.17 & 7.6 \\
\hline 47WS 2 & 08/19/2004 & 7.5 & 0.5 & USGS & 7.370 & 6.100 & 34.71 & 1.25 & 24.319 & 25.06 & nd \\
\hline 47WS 10 & 08/12/2005 & 7.3 & 0.6 & USGS & 7.558 & 4.866 & 7.64 & 1.30 & 20.804 & 6.90 & nd \\
\hline $47 X S 3$ & 08/19/2004 & 6.9 & 0.5 & USGS & 7.030 & 4.660 & 2.45 & -2.03 & 24.320 & 23.94 & nd \\
\hline 47XS 6 & 08/19/2004 & 6.6 & 0.5 & USGS & 7.260 & 5.318 & 17.93 & -0.04 & 22.423 & 15.90 & nd \\
\hline
\end{tabular}

${ }^{a}$ Water samples for the determination of tritium $\left({ }^{3} \mathrm{H}\right)$ in the U.S. Geological Survey Low-Level ${ }^{3} \mathrm{H}$ Laboratory, Menlo Park, CA, were enriched electrolytically and analyzed by liquid scintillation counting following procedures modified from Thatcher and others (1977). Water samples for the determination of ${ }^{3} \mathrm{H}$ in the Noble Gas Laboratory at Lamont-Doherty Earth Observatory of Columbia University, Palisades, NY, were analyzed by the helium-3 ingrowth method (Clarke and others, 1976; Bayer and others, 1989).

${ }^{\mathrm{b}}$ Water samples for the determination of helium-4 $\left({ }^{4} \mathrm{He}\right)$ in the U.S. Geological Survey Chlorofluorocarbon Laboratory in Reston, VA, were analyzed using gas chromatography procedure with a thermal conductivity detector, which is similar to the procedure described by Sugisaki and others (1982) (see http://water.usgs.gov/lab/cfc/, accessed January 6, 2010).

${ }^{c}$ Water samples for the determination of helium-3 $\left(\delta^{3} \mathrm{He}\right)$, helium-4 $\left({ }^{4} \mathrm{He}\right)$, and neon $(\mathrm{Ne})$ in the Noble Gas Laboratory at Lamont-Doherty Earth Observatory of Columbia University, Palisades, NY, were analyzed by mass-spectrometric procedures outlined in Ekwurzel and others (1994) and Ludin and others (1998). 
Appendix 12. Summary of apparent tritium/helium-3 ages in water samples from springs in Clarke County, Virginia, 2003-2005.

[uncorr., apparent age not corrected for terrigenic helium; uncorr. err., one standard deviation age error of uncorrected apparent age; corr., apparent age corrected for terrigenic helium; corr. err., one standard deviation age error of apparent age corrected for terrigenic helium; terr. He, terrigenic helium; Y, yes, terrigenic helium correction needed; N, no, terrigenic helium correction not needed; nd, not determined; All apparent age calculations based on recharge temperatures determined for the respective samples. See figure 28 for location of springs]

\begin{tabular}{lcccccccc}
\hline \multirow{2}{*}{$\begin{array}{c}\text { USGS } \\
\text { local no. }\end{array}$} & Date & $\begin{array}{c}\text { Uncorr. } \\
\text { (years) }\end{array}$ & $\begin{array}{c}\text { Uncorr err. } \\
\text { (years) }\end{array}$ & $\begin{array}{c}\text { Corr. } \\
\text { (years) }\end{array}$ & $\begin{array}{c}\text { Corr } \text { err. } \\
\text { (years) }\end{array}$ & $\begin{array}{c}\text { Terr. He } \\
\text { (Y/N) }\end{array}$ & $\begin{array}{c}\text { Final } \\
\text { (years) }\end{array}$ & $\begin{array}{c}\text { Final error } \\
\text { (years) }\end{array}$ \\
\hline 46WS 1 & $08 / 13 / 2003$ & 3.9 & 0.3 & 6.9 & 0.5 & $\mathrm{Y}$ & 6.9 & 0.5 \\
46WS 2 & $08 / 20 / 2003$ & 1.2 & 0.2 & -0.5 & 0.4 & $\mathrm{~N}$ & 1.2 & 0.2 \\
46WS 3 & $08 / 13 / 2003$ & 2.9 & 0.3 & 3.1 & 1.0 & $\mathrm{~N}$ & 2.9 & 0.3 \\
46WS 5 & $08 / 11 / 2005$ & -1.2 & 0.2 & 1.5 & 0.3 & $\mathrm{~N}$ & nd & nd \\
46WS 7 & $08 / 11 / 2005$ & 9.2 & 0.7 & 10.5 & 0.7 & $\mathrm{~N}$ & 9.2 & 0.7 \\
46WS 10 & $08 / 11 / 2005$ & 1.6 & 0.1 & 11.8 & 0.6 & $\mathrm{Y}$ & 11.8 & 0.6 \\
46WS 22 & $08 / 13 / 2003$ & -1.0 & 0.3 & 3.1 & 0.5 & $\mathrm{Y}$ & 3.1 & 0.5 \\
46XS 3 & $08 / 19 / 2004$ & 1.9 & 0.3 & 5.8 & 0.4 & $\mathrm{Y}$ & 5.8 & 0.4 \\
46XS 7 & $08 / 11 / 2005$ & $\mathrm{nd}$ & $\mathrm{nd}$ & 19.9 & 0.9 & $\mathrm{Y}$ & 19.9 & 0.9 \\
46XS 8 & $08 / 13 / 2003$ & 2.1 & 0.2 & 1.4 & 0.5 & $\mathrm{~N}$ & 2.1 & 0.2 \\
46XS 9 & $08 / 19 / 2004$ & 3.0 & 0.3 & -0.7 & 0.5 & $\mathrm{~N}$ & 3.0 & 0.3 \\
47WS 2 & $08 / 19 / 2004$ & 1.9 & 0.2 & 3.8 & 0.4 & $\mathrm{~N}$ & 1.9 & 0.2 \\
47WS 10 & $08 / 12 / 2005$ & 1.8 & 0.2 & 1.3 & 0.4 & $\mathrm{~N}$ & 1.8 & 0.2 \\
47XS 3 & $08 / 19 / 2004$ & nd & nd & nd & nd & nd & nd & nd \\
47XS 6 & $08 / 19 / 2004$ & 1.1 & 0.3 & 0.0 & 0.5 & $\mathrm{~N}$ & 1.1 & 0.3 \\
\hline
\end{tabular}


Appendix 13. Summary of oxygen $\left(\delta^{18} \mathrm{O}\right)$ and hydrogen $\left(\delta^{2} \mathrm{H}\right)$ isotopic data in water samples from springs in Clarke County, Virginia, 2003-2005.

[per mil, parts per thousand; $\delta=\left[\left(\mathrm{R}_{\text {sample }} / \mathrm{R}_{\text {standard }}\right)-1\right] \times 1,000$, where $\mathrm{R}$ is an isotope ratio; $2 \sigma, 2$ standard deviations; The $2 \sigma$ precision of oxygen- and hydrogen-isotope results is 0.2 and 1.5 per mil, respectively; $d$, deuterium excess. See figure 28 for location of springs]

\begin{tabular}{ccccc}
\hline $\begin{array}{c}\text { USGS } \\
\text { local no. }\end{array}$ & Date & $\begin{array}{c}\boldsymbol{\delta}^{\mathbf{1 8}} \mathbf{0} \\
\text { (per mil) }^{\mathbf{a}}\end{array}$ & $\begin{array}{c}\boldsymbol{\delta}^{\mathbf{2}} \\
\text { (per mil) }^{\mathbf{a}}\end{array}$ & $\begin{array}{c}\boldsymbol{d} \\
\text { (per mil) }\end{array}$ \\
\hline 46WS 1 & $08 / 13 / 2003$ & -8.11 & -51.3 & 13.6 \\
46WS 2 & $08 / 20 / 2003$ & -8.14 & -50.8 & 14.3 \\
46WS 3 & $08 / 13 / 2003$ & -8.26 & -51.7 & 14.4 \\
46WS 5 & $08 / 11 / 2005$ & -7.59 & -47.0 & 13.7 \\
46WS 7 & $08 / 11 / 2005$ & -7.99 & -49.6 & 14.3 \\
46WS 10 & $08 / 11 / 2005$ & -7.95 & -49.6 & 14.0 \\
46WS 22 & $08 / 13 / 2003$ & -7.98 & -50.0 & 13.8 \\
46XS 3 & $08 / 19 / 2004$ & -8.14 & -49.9 & 15.2 \\
46XS 7 & $08 / 11 / 2005$ & -7.99 & -48.6 & 15.3 \\
46XS 8 & $08 / 13 / 2003$ & -8.36 & -53.1 & 13.8 \\
46XS 9 & $08 / 19 / 2004$ & -7.89 & -48.9 & 14.2 \\
47WS 2 & $08 / 19 / 2004$ & -8.11 & -50.1 & 14.8 \\
47WS 10 & $08 / 12 / 2005$ & -8.10 & -49.2 & 15.6 \\
47XS 3 & $08 / 19 / 2004$ & -8.13 & -49.5 & 15.5 \\
47XS 6 & $08 / 19 / 2004$ & -8.11 & -50.3 & 14.6 \\
\hline
\end{tabular}

${ }^{a} \delta^{18} \mathrm{O}$ and $\delta^{2} \mathrm{H}$ were determined on water samples at the U.S. Geological Survey Stable Isotope Laboratory, Reston, VA. The stable isotope results are reported in per mil relative to VSMOW (Vienna Standard Mean Ocean Water; Coplen, 1996) and normalized (Coplen, 1988) on scales such that the oxygen and hydrogen isotopic values of SLAP (Standard Light Antarctic Precipitation) are -55.5 and -428 per mil, respectively.

${ }^{\mathrm{b}}$ Deuterium excess is defined as $d=\delta^{2} \mathrm{H}-8 \delta^{18} \mathrm{O}$ by Clark and Fritz (1997). 


\section{Prepared by:}

USGS Publishing Network

Raleigh Publishing Service Center

3916 Sunset Ridge Road

Raleigh, NC 27607

For additional information regarding this publication, contact:

David L. Nelms, Groundwater Specialist

USGS Virginia Water Science Center

1730 East Parham Road

Richmond, VA 23228

email: dlnelms@usgs.gov

Or visit the USGS Virginia Water Science Center Web site at: http://va.water.usgs.gov/ 

